\title{
ideia, obra e concretude representações na construção de Goiânia
}

\section{autor}

Leonardo Dimitry Silva Guimarães

orientador

Prof. Carlos Alberto Ferreira Martins

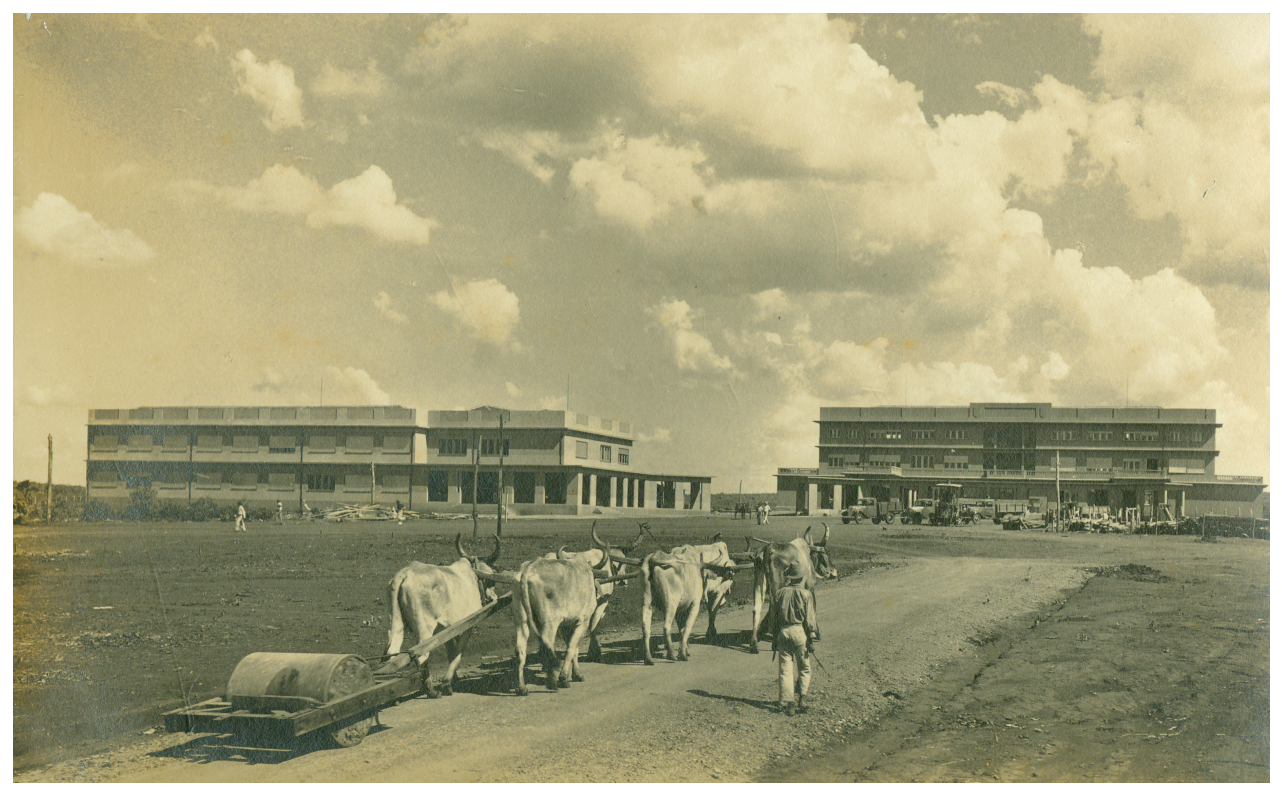

São Carlos

2019 
Ideia, obra e concretude: representações na construção de Goiânia

\section{Versão corrigida}

Dissertação apresentada ao Programa de Pósgraduação do Instituto de Arquitetura e Urbanismo da Universidade de São Paulo, como requisito para obtenção do título de Mestre em Arquitetura e Urbanismo.

Área de concentração: Teoria e História da Arquitetura e do Urbanismo

Orientador: Prof. Tit. Carlos Alberto Ferreira Martins

São Carlos 


\section{AUTORIZO A REPRODUCAO TOTAL OU PARCIAL DESTE TRABALHO, POR QUALQUER MEIO CONVENCIONAL OU ELETRONICO, PARA FINS DE ESTUDO E PESQUISA, DESDE QUE CITADA A FONTE}

Ficha catalográfica elaborada pela Biblioteca do Instituto de Arquitetura e Urbanismo com os dados fornecidos pelo(a) autor(a)

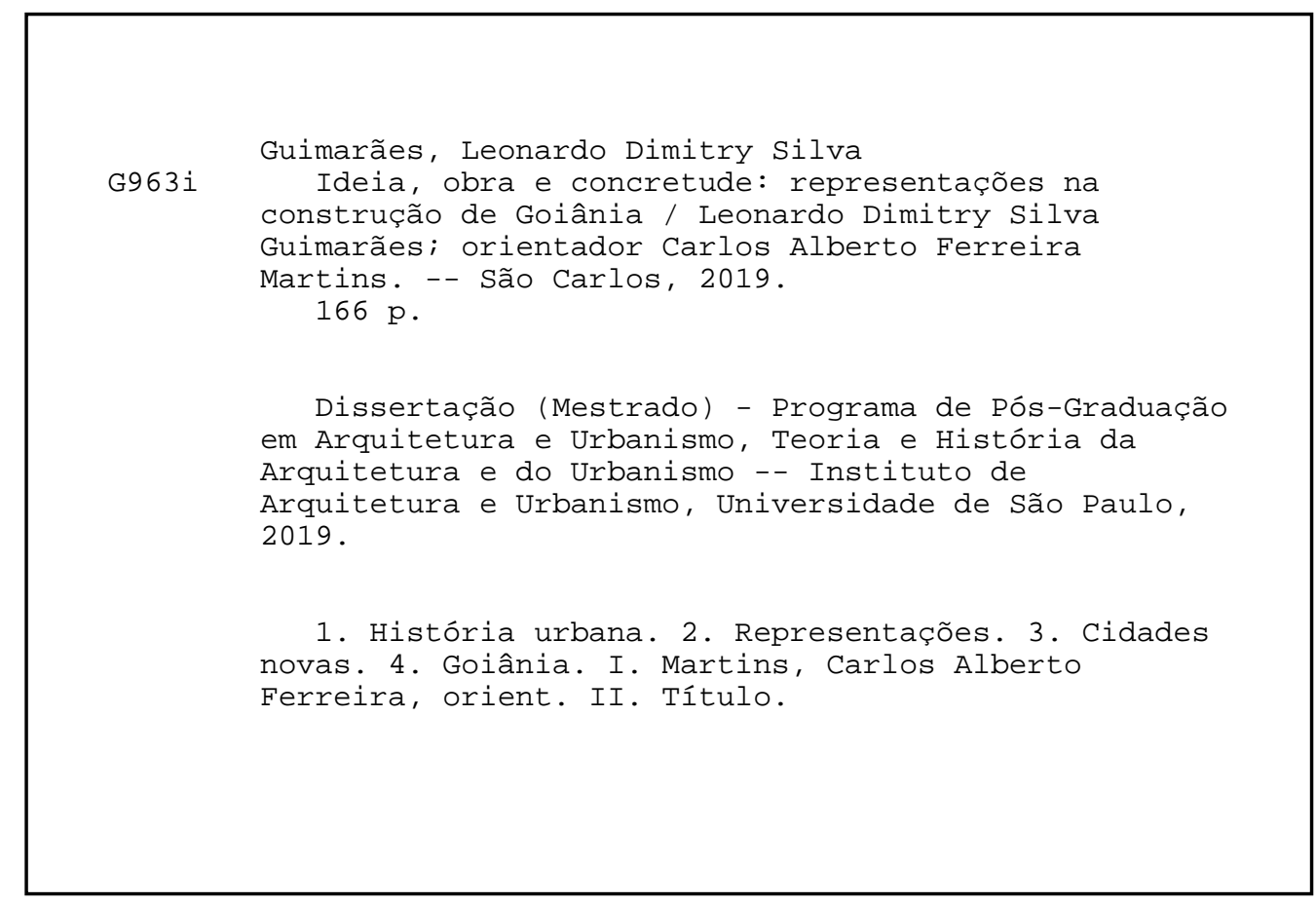

Bibliotecária responsável pela estrutura de catalogação da publicação de acordo com a AACR2:

Brianda de Oliveira Ordonho Sígolo - CRB - 8/8229 


\section{FOLHA DE JULGAMENTO}

\section{Candidato(a): Leonardo Dimitry Silva Guimarães}

Título da dissertação: "Ideia, obra e concretude: representações na construção de Goiânia"

Data da defesa: 16/12/2019

Orientador: Prof. Dr. Carlos Alberto Ferreira Martins

Comissão Julgadora:

\section{Resultado:}

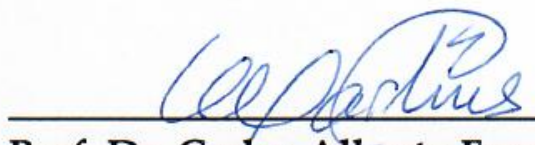

Prof. Dr. Carlos Alberto Ferreira Martins Não votante (IAU/USP)

\section{Prof.Dr. Abílio da Silva Guerra Neto}
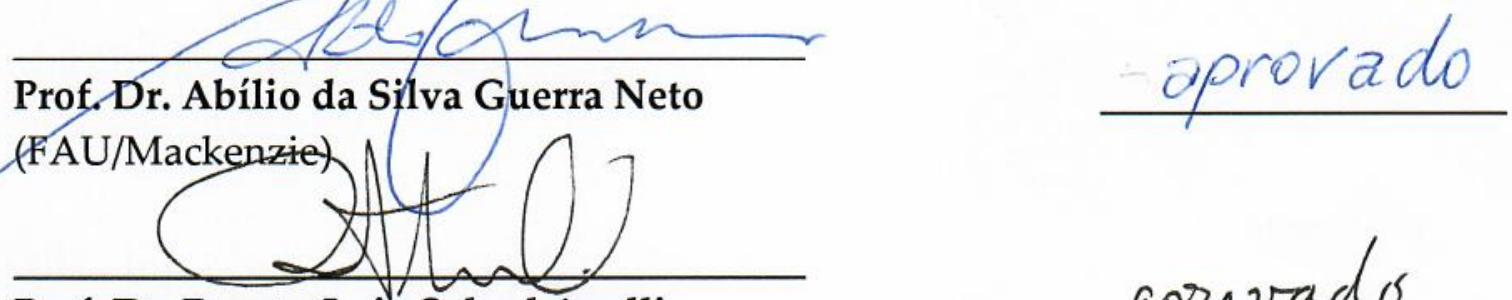

Prof. Dr. Renato Luiz Sobral Anelli (IAU/USP)

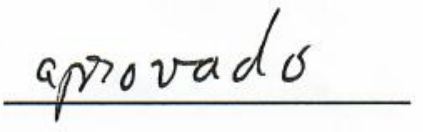

Profa. Dra. Maria Beatriz Camargo Cappello ApnOVADO (FAUeD)
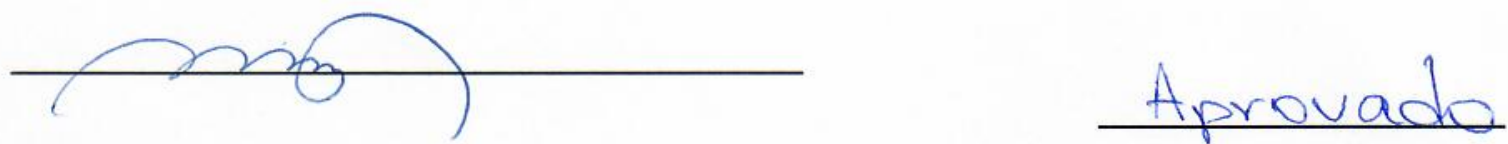

Coordenador e Presidente da Comissão de Pós-Graduação do Programa de PósGraduação em Arquitetura e Urbanismo: Prof. Dr. Tomás Antonio Moreira. 
A Walter Rodrigues e Carmelita Alves Guimarães, que partiram antes do desfecho deste ato. 


\section{AGRADECIMENTOS}

Agradeço ao Pai, presente em cada passo desta jornada.

Ao meu orientador, Carlos Ferreira Martins, por confiar em meu trabalho desde o princípio.

A Sarah Feldman e Fernanda Arêas Peixoto, pelas valiosas considerações no exame de qualificação.

Aos docentes e funcionários do Instituto de Arquitetura e Urbanismo de São Carlos que, de diferentes modos, tanto contribuíram ao longo desta trajetória.

Aos servidores da Secretaria Municipal de Planejamento Urbano e Habitação de Goiânia, do Instituto Histórico e Geográfico de Goiás, do Arquivo Histórico Estadual de Goiás e, em especial, do Museu da Imagem e do Som de Goiás, pelo auxílio nas incontáveis horas em meio aos acervos.

À Universidade Federal de Goiás, cuja licença tornou possível a realização desta pesquisa, bem como aos meus colegas da Secretaria de Infraestrutura.

Aos amigos de Goiânia, presentes apesar da distância, e aos amigos de São Carlos, capazes de tornar a caminhada mais leve.

Aos numerosos membros das famílias Silva e Guimarães, por fazerem parte de quem sou.

Aos meus pais Klicia e Bosco, por me mostrarem desde cedo o poder da educação; à minha irmã, Maria Gabriela, pelo companheirismo; e à minha sogra, Maria Aparecida, pelo apoio.

Por fim, com muito carinho, agradeço a Helen, minha esposa, pelo amor imensurável. 


\section{RESUMO}

GUIMARÃES, Leonardo Dimitry Silva. Ideia, obra e concretude: representações na construção de Goiânia. 2019. 166 f. Dissertação (Mestrado em Arquitetura e Urbanismo) Instituto de Arquitetura e Urbanismo, Universidade de São Paulo, São Carlos, 2019.

Sob a perspectiva da construção de Goiânia, a abordagem desta pesquisa propõe compreender como o espaço e suas representações se relacionavam nas leituras da cidade, permeando o engendramento de uma trama discursiva e a consolidação física e simbólica da nova capital de Goiás. Na condição de primeira capital brasileira planejada do século XX, Goiânia derivou de um plano urbanístico envolto na simbologia de modernidade, sempre contraposta aos traços coloniais da antiga capital do estado, Cidade de Goiás. Neste cenário de transição, contudo, o próprio novo núcleo urbano conformava-se de modo paradoxal: ao passo que grandes movimentos atuavam na construção de uma identidade amparada no progresso, a capital goiana transparecia carências próprias de uma cidade nova em vias de estabelecimento no coração do país. Imersa neste contexto de coexistências - e identificando a cidade como produto e produtora de representações -, a dissertação estabelece um olhar às leituras acerca de Goiânia que, traduzidas e mediadas por imagens que transitavam entre o "arcaico" e o moderno, seriam capazes de consolidar (ou moldar, conforme as relações de poder) os discursos dialéticos e, numa relação mútua, igualmente reverberariam na conformação e apreensão da cidade. Para subsidiar a análise, o trabalho emprega como fio condutor elementos iconográficos, em especial as fotografias, consideradas como privilegiados suportes de representações urbanas. Apoia-se também na análise da textualidade de publicações e periódicos contemporâneos à construção de Goiânia, bem como relatos de moradores e viajantes, cotejando as múltiplas leituras entre si.

Palavras-chave: História urbana; representações; cidades novas; Goiânia. 


\begin{abstract}
GUIMARÃES, Leonardo Dimitry Silva. Idea, work and concreteness: representations in the construction of Goiânia. 2019. 166 f. Dissertação (Mestrado em Arquitetura e Urbanismo) Instituto de Arquitetura e Urbanismo, Universidade de São Paulo, São Carlos, 2019.

From the perspective of the construction of Goiânia, the approach of this research proposes to understand how the space and its representations were related in the interpretations of the city, permeating the arrangement of a discursive tissue and the physical and symbolic consolidation of the new capital of Goiás. As the first planned capital of Brazil in the twentieth century, Goiânia derived from an urban plan shrouded in the symbolism of modernity, always opposed to the colonial features of the old capital of the state, Cidade de Goiás. In this transition scenario, however, the new urban nucleus itself was paradoxical: while large movements were working to build an identity based on progress, the capital of Goiás showed the needs of a new city on the way to establishment in the core of the country. Immersed in this context of coexistences - and identifying the city as a product and producer of representations -, the dissertation establishes a look at the interpretations about Goiânia that, translated and mediated by images that ranged from "archaic" to the modern, would be able to consolidate (or shape, according to the relations of power) the dialectical discourses and, in a mutual relation, would equally reverberate in the conformation and apprehension of the city. In order to subsidize the analysis, the work employs iconographic elements, especially the photographs, considered as privileged supports of urban representations. It also relies on the analysis of the textuality of publications and journals contemporaneous to the construction of Goiânia, as well as accounts of residents and travelers, comparing the multiple interpretations among themselves.
\end{abstract}

Keywords: Urban history; representations; new cities; Goiânia. 


\section{LISTA DE ILUSTRAÇÕES}

Figura 1: A Cidade de Goiás num croqui de Attilio Corrêa Lima 40

Figura 2: "A praça principal da Cidade de Goiás. Mostrando a prisão e a biblioteca pública"

Figura 3: "Goiás, antiga Vila Boa, capital da capitania de Goiás"

Figura 4: "A fixação do núcleo central da nova capital - o urbanista Correia Lima, o que se vê no centro, determina o local onde deve ser colocada a pedra fundamental do Palácio do Governo".

Figura 5: "Planta da cidade. Projeto do arquiteto urbanista Atilio Correia Lima" 53

Figura 6: Bosque dos Buritis 57

Figura 7: Propagandas da Firma Coimbra Bueno \& Cia Ltda. em jornais de circulação nacional.

Figura 8: Perspectiva do Centro Cívico.

Figura 9: Maquete do Centro Cívico

Figura 10: Maquete do Centro Cívico na Exposição de Viação e Obras Públicas, no Rio de Janeiro 65

Figura 11: Plantas de Goiânia, com o Setores Central, Norte e Sul 67

Figura 12: Campinas entre 1934 e 1935 72

Figura 13: Levantamento aéreo de 1935 73

Figura 14: Levantamento aéreo de 1936 74

Figura 15: Levantamento aéreo de 1937 .74

Figura 16: Goiânia em 1937 75

Figura 17: Pôster de Goiânia 78

Figura 18: Reportagem sobre o $9^{\circ}$ aniversário de Goiânia 80

Figura 19: "Palácio do Governo, em construção" 81

Figura 20: "Palácio do Governo (ao se iniciar a pintura externa)" 81

Figura 21: "Palácio do Governo, em Goiânia". 82

Figura 22: Operários no Palácio do Governo 86 
Figura 23: Venerando de Freitas Borges com trabalhadores em abertura de estrada, década de 1930

Figura 24: "Os trabalhos preparatórios: operários abrindo os primeiros arruamentos, em 1934 e 1935, nas planuras dos arredores de Campinas, onde se construiu a Nova Capital do Estado de Goiás"

Figura 25: "O prédio da Assembleia Legislativa, na Av. Tocantins, que foi construído em quase 40 dias, em meados de 1936. Ao fundo, o edifício do 'Grande Hotel', na Avenida Goiás"

Figura 26: Delegacia Fiscal em construção

Figura 27: Seção de Arquitetura. 97

Figura 28: Croqui da obra do Cine-Teatro Goiânia. 98

Figura 29: Construção do Cine-Teatro Goiânia, década de 1940. 98

Figura 30: "Extração das primeiras pedras que serviram para a construção da cidade" 99

Figura 31: "Os materiais sempre foram submetidos a provas de resistência: vê-se a experimentação das vigas que eram empregadas nas obras".....

Figura 32: "A marcenaria do Estado, reaparelhada pelos engenheiros Coimbra Bueno, no bairro 'Botafogo': foi uma das indústrias locais que melhores resultados trouxeram, para a economia das obras; todas as esquadrias e mobiliário, mesmo de fino acabamento, foram executadas nessa marcenaria"

Figura 33: Rolo-compressor em frente ao Escritório Central.

Figura 34: "Os problemas do transporte. No transporte de mercadoria e de abastecimento, era usual o aproveitamento do carro-de-boi" 103

Figura 35: Burros de carga 105

Figura 36: Carros de boi na Praça Cívica, 1936 106

Figura 37: Rua da Liberdade, São Paulo, c. 1937 107

Figura 38: Construção do Tesouro Americano em Washington D.C., com bois em primeiro plano no lado sul. 108

Figura 39: Secretariado de Chandigarh em construção .....

Figura 40: Capa da obra Anais do Batismo Cultural de Goiânia.

Figura 41: Peça publicitária em jornal, c. década de 1980 
Figura 43: Edifícios da Delegacia Fiscal em Goiás e Goiânia

Figura 44: Edifícios do Juízo Federal em Goiás e Goiânia

Figura 45: Exemplo de divulgação em capa de jornal datado de 24 de Outubro de 1939 .....117

Figura 46: Parte superior da reportagem sobre o crematório ................................................. 120

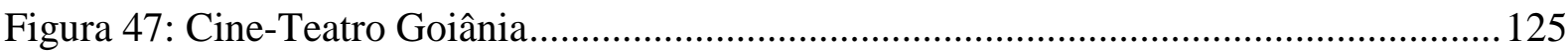

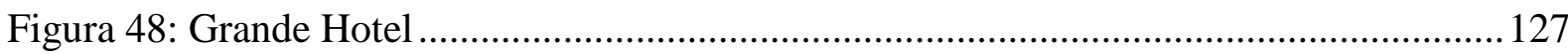

Figura 49: Grande Hotel em recorte do jornal $O$ Popular.................................................. 129

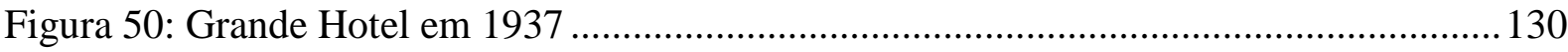

Figura 51: O problema de desabastecimento em recortes de jornais .................................. 132

Figura 52: "Instalação de luz elétrica, nos prédios tipo 'casas-modelo', - da Rua 20 (detalhe)".

Figura 53: "A nova capital de Goiaz vai sendo, pouco a pouco, enriquecida de belas e confortáveis habitações particulares"

Figura 54: Residência de Pedro Ludovico Teixeira. "Goiânia - tipo de casa residencial"..... 136

Figura 55: "Também os operários não foram esquecidos em a nova capital que surge no centro do coração do Brasil: algumas habitações do bairro proletário"

Figura 56: Casa provisória e Palácio do Governo

Figura 57: "A pequena cidade improvisada pelos trabalhadores que construíram Goiânia (Bairro Botafogo)"

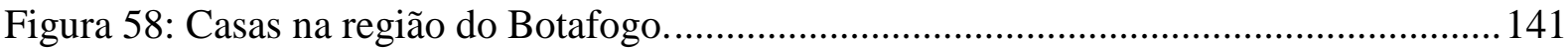

Figura 59: As representações de verticalização.................................................................... 143

Figura 60: Sede da Sociedade Goiana de Pecuária................................................................. 144

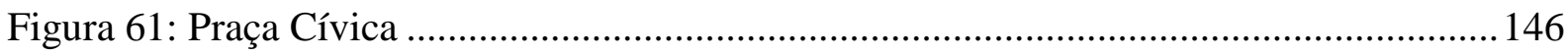

Figura 62: "Aspecto do Centro Cívico, onde se acham localizados todos os principais edifícios públicos de Goiânia"

Figura 63: Palácio do Governo e Praça Cívica. 


\section{LISTA DE SIGLAS}

AHEG

CPDOC-FGV

IMS

MIS-GO

SEPLANH
Arquivo Histórico Estadual de Goiás

Centro de Pesquisa e Documentação de História Contemporânea do Brasil da Fundação Getúlio Vargas

Instituto Moreira Salles

Museu da Imagem e do Som de Goiás

Secretaria Municipal de Planejamento Urbano e Habitação 


\section{SUMÁRIO}

INTRODUÇÃ

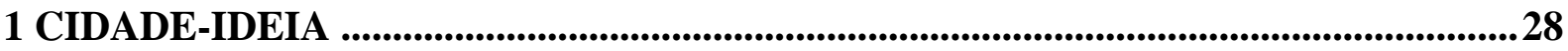

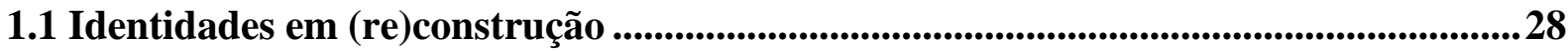

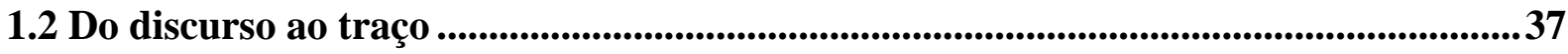

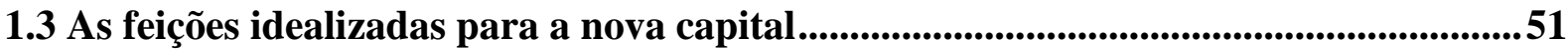

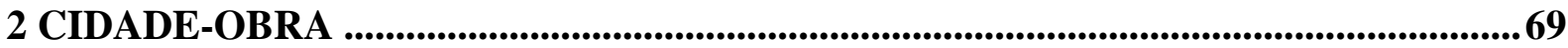

2.1 A construção e as imagens do progresso ...................................................................69

2.2 A construção e as imagens do labor ..............................................................................86

2.3 A construção e as imagens das coexistências ........................................................................... 101

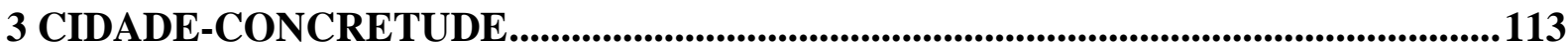

3.1 Notas sobre as dialéticas na nova capital ....................................................................113

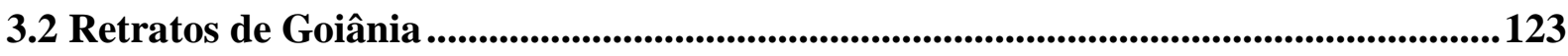

CONSIDERAÇÕES FINAIS ..................................................................................................................... 150

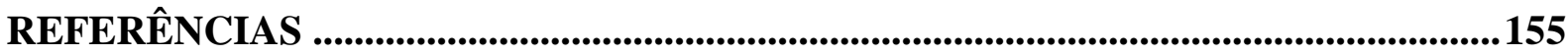

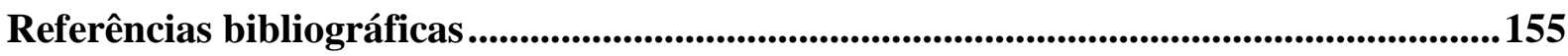

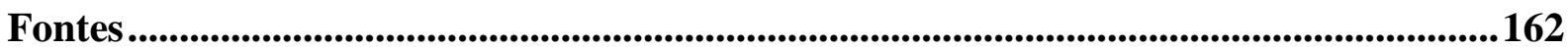




\section{Introdução}




\section{INTRODUÇÃO}

A dissertação Ideia, obra e concretude: representações na construção de Goiânia propõe, a partir de uma ótica cultural, estabelecer um olhar sobre a construção da capital de Goiás, no período que compreende os anos entre 1933 e $1950^{1}$. Depreendendo a cidade não apenas como materialidade fruto de um desígnio urbanístico - que, por si só, também muito exprime acerca de um tempo - e igualmente assumindo-a como plataforma de memória, privilegiado produto e produtor de representações, a abordagem intenta desvelar as leituras que, integrantes de uma trama discursiva moldada por inúmeros agentes, permeariam a consolidação física e simbólica da nova capital.

O princípio deste recorte temporal remete à capital goiana ainda disposta no campo da idealização. Embora os primeiros juízos acerca da transferência da capital habitem relatórios oficiais pelo menos desde o século XVIII (sobretudo a partir de críticas às condições de acesso e salubridade da Cidade de Goiás, então sede administrativa, paulatinamente substancializando uma imagem associada à decadência e ao atraso), é no cenário esboçado ao término da Primeira República que a ideia encontra lastro suficientemente propício para ser viabilizada, num contexto regional e nacionalmente particular.

No âmbito nacional, em meio às múltiplas mudanças derivadas do que se chamaria de Revolução de 1930, uma dinâmica distinta é conduzida por um novo governo de caráter cada vez mais centralizador. Aparentemente a partir daí se teriam as condições convenientes para, por meio um Estado intervencionista, buscar a constituição de uma nacionalidade frente à profusa segmentação e fragmentação - política, territorial, econômica e social - que persistiam no alvorecer daquele século no Brasil. Concomitantemente, na escala regional, a nomeação de Pedro Ludovico Teixeira como interventor, em princípio marcaria a adesão de Goiás ao projeto de nação orientado, principalmente, pela ideia de progresso como via de agregação. Diante da representação do vazio, "tão ativa no imaginário estatal-construtivista latino-americano, seja como obstáculo, seja como veículo de modernização" (GORELIK,

\footnotetext{
${ }^{1}$ Embora o recorte temporal não pressuponha estremas rígidas, uma vez que determinados diálogos transcendem seus limites, assumimos como "construção de Goiânia" o decurso entre os anos de 1933 e 1950, seguindo a linha de instituições e autores como Bernardes (2000), Museu da Imagem e do Som de Goiás (2001), Gonçalves (2002) e M. E. J. Ribeiro (2004). O ano de 1933 remete ao lançamento da pedra fundamental da cidade, numa fundação mais simbólica que efetiva, enquanto o ano de 1950 marca o início de um ciclo distinto de crescimento urbano - ciclo que começa a esboçar-se com o fim do Estado Novo em 1945, com a aprovação do novo Código de Edificações de Goiânia em 1947 (cujas diretrizes ampliavam o limite da área de expansão urbana) e que culminaria, por fim, na aprovação da Lei ${ }^{\circ} 76$ em 1950, que isentaria os loteadores de prover infraestrutura em novos bairros. O que se observaria a partir de então seria que o crescimento, a princípio orientado pelo plano urbanístico original - salvo poucas modificações significativas - assumiria outra dinâmica, intensificada ainda pela construção da nova capital federal perto dali, logo depois.
} 
2005), integrar o hinterland ao país era crucial, especialmente num novo momento de acumulação do capital. Destarte, em consonância ao governo central, a questão do desenvolvimento também é assumida como tônica pelo poder local - e, como corolário, a construção de uma nova capital passa a ser a principal bandeira encampada.

Longe de ser um processo isento de embates, sobretudo em meio às motivações dos grupos mudancistas e antimudancistas, a afirmação de Goiânia como uma realidade possível não se restringiria à sua concretização física, mas similarmente se inseriria no eixo discursivo. Desta forma, antes mesmo do primeiro tijolo assentado ou da primeira via delineada, a legitimação da nova capital se daria através de sua construção simbólica alicerçada num movimento de avanço. Goiânia seria fruto de um novo Goiás. Goiânia seria fruto de um novo Brasil.

\begin{abstract}
O Brasil liberal era um Brasil fraquinho. Brasil-maria-vai-com-as-outras, que ia para onde o levavam os senhores do mundo. [...] Europeite integral, muito lustrosa e bonita por fora, porém desprovida de realidade, de conteúdo nacional, de substância humana. [...] Em 30, quase agonizante, o Brasil parecia que ia acabar de acabar. Mas não acabou; o que acabou foi o Brasil liberal. E a morte do Brasil liberal foi a ressurreição do Brasil brasileiro. [...] E o Brasil cresceu em si. Verdeamarelizou-se. Oestizou-se. Personalizou-se. E então, sadio, potente, casou-se com a Nação. A Europa, amiga antiga, chorou, ameaçou. Mas foi inútil: - o Brasil tinha se regenerado. Abandonara a orgia, ia começar vida nova. Casou-se com a Nação, e a prole veio, numerosa, pura, magnífica: - legislação trabalhista excelente, aviação florescente, e mais siderurgia, açudes, colônias agrícolas, leprosários, institutos de assistência social, escolas técnicas, baixada fluminense saneada, hospitais e mais hospitais, marinha renovada, exército forte, ensino bem orientado, administração aperfeiçoada, e, afinal, Goiânia. Goiânia é a filha mais moça e mais bonita do Brasil. Por isso, sua filha predileta. Robusta, tropical. A cara do pai. Tem o seu mesmo sentimento sertanejo, o mesmo espírito bandeirante, a sua mesma alma cristã. [...] (FIGUEIREDO, P. A., 1942, p. 5)
\end{abstract}

Como veremos, não se pode presumir a existência de um Goiás estagnado, imóvel no tempo, no período que precede a década de 1930. Porém, nas novas relações de força que se estabelecem a partir de então, se articulariam determinadas operações estruturadas por uma lógica dicotômica que, em Goiás, se encarnavam nas figuras da antiga e da nova capital: supostamente substituía-se o arcaico pelo moderno, o atraso pelo progresso.

Advém desta conjuntura, outrossim, a concepção urbanística de Goiânia contemporânea à formação e consolidação do urbanismo como espaço de reflexão e prática profissional no Brasil -, orientada de modo a exprimir materialmente o novo tempo que se enunciava. Elaborado em meio a uma trama composta por nomes de projeção no panorama nacional (como Attilio Corrêa Lima e Armando Augusto de Godoy), o plano se alinharia a diversos debates urbanísticos correntes em escala global, dando corpo assim ao discurso modernizante. O saber técnico, o mesmo que munia as argumentações acerca da necessidade de mudança da capital, garantiria a ação civilizadora por meio de uma cidade moderna, 
condutora "dos movimentos e das atividades de uma nação", sem a qual "os povos não progridem e não prosperam" (GODOY, 1933/1943, p. 212).

Multiformemente sedimentados, tais motes se apresentariam expressivamente absorvidos, entre outros, por parte da historiografia (e do imaginário) goianiense. Na obra Como nasceu Goiânia (MONTEIRO, O. S. N., 1938), considerada por Sandes e Arrais (2014) como precursora da matriz historiográfica que se seguiu, a ideia de ruptura é reforçada mediante uma narrativa que se inicia na desqualificação da Cidade de Goiás - ao recuperar os argumentos sobre o deslocamento premente da sede administrativa - e centra-se na construção de Goiânia, da gestação (estudos para escolha do local, diretrizes urbanísticas e movimentações para provisão de infraestrutura) a fato concreto (primeiros acontecimentos da cidade, mudança definitiva da capital e as repercussões na imprensa nacional). $O$ engendramento da narrativa se arrimaria na reunião de uma grande massa documental, mediante uma coesa bricolagem que marcaria a cristalização de dois tempos.

\begin{abstract}
Ao tomar a construção de Goiânia como objeto de interesse, a autora constrói uma cadeia casual entre o passado e presente, afirmando não só que as expectativas dos homens do passado estavam se concretizando no presente, mas também que existia uma conexão interna, uma ligação necessária entre os dois momentos. A escolha da documentação, cuja pretensão era reforçar a casualidade e a conexão, aludiu, de um lado, a um passado remoto, representado pela decadência e pelo atraso, e, de outro, uma experiência política, cujo novo era positivado em sua qualidade única de novidade, sinônimo irrestrito de um empreendimento rumo ao progresso. (SANDES; ARRAIS, 2014, p. 403)
\end{abstract}

Em narrativas similares, seguiriam as demais publicações que aqui chamamos de pioneiras, contemporâneas à construção de Goiânia, sendo que várias dessas remetem ao ano de 1942 (ocasião na qual ocorre a inauguração oficial da cidade, o chamado Batismo Cultural). Dentre elas, pode-se citar A luta na epopeia de Goiânia: uma obra da engenharia nacional - que, segundo o autor (ALVARES, 1942), debruça-se sobre os aspectos técnicos e descritivos do plano, bem como sobre a luta pela sua execução -, Goiânia, a Metrópole do Oeste (COSTA, G. C., 1942/1985) - resultado de um concurso instituído pela Academia Goiana de Letras, que almejava premiar a melhor obra sobre o sentido ideológico da realização de Goiânia - e Goiânia - uma coletânea editada pelo Instituto Brasileiro de Geografia e Estatística (1942), composta por documentos de políticos (Getúlio Vargas, Pedro Ludovico), técnicos (Attilio Corrêa Lima, Armando Augusto de Godoy) e pesquisadores (Pierre Monbeig, Afonso Várzea), entre outros. Ainda na década de 1940, tem-se a publicação da Monografia corográfica e histórica da nova capital de Goiaz (ARTIAGA, 1949) que, por um lado, se ampararia no conteúdo das obras anteriores e, por outro, apresentaria novos dados estatísticos, capazes de sinalizar uma cidade aparentemente estabelecida. Em suma, identifica- 
se uma tônica essencialmente uníssona que, conforme resumiriam Sandes e Arrais (2014, p. 404), colocaria o atraso e a decadência como motivações basilares para a transferência da sede administrativa e, ao mesmo tempo, inseririam Goiânia num "tempo dominado pelo presente, sendo a cidade transformada em um ícone" - ainda que eventualmente carregada de vicissitudes.

A partir deste quadro - onde, diga-se de passagem, a história urbana apareceria como tributária da história política -, percebe-se uma dominância assumida pela linha discursiva desta matriz historiográfica que persistiria ao longo das décadas, de modo que apenas recentemente medrariam novos olhares historiográficos. O questionamento à memória da decadência, por exemplo, é anterior a Goiânia - embora possa aparentar florescer concomitantemente à nova capital; todavia, é relativamente recente o tensionamento da matriz decadentista na historiografia (SANDES; ARRAIS, 2014), num movimento que somente toma forma a partir da década de 1990. Em História da terra e do homem no Planalto Central. Eco-história do Distrito Federal: do indígena ao colonizador, originalmente publicado em 1994, Bertran (1994/2000) alertaria sobre os eurocêntricos juízos de valor emitidos por viajantes estrangeiros que visitaram a região no século XIX. Poucos anos depois, em Caminhos de Goiás: da construção da decadência aos limites da modernidade, Chaul (1997/2010, p. 268) mapearia as origens das representações de decadência e atraso que marcariam um Goiás pré-1930 e concluiria que, afinal, o estado não era nem um, nem outro, "apenas caminhava de acordo com suas possibilidades, no ritmo estabelecido pelo lugar que ocupava no conjunto da sociedade brasileira". Na mesma esteira, ainda pode-se pontuar outros trabalhos pospositivos, como do próprio Chaul (2000) e Sandes (2002).

Ao mesmo tempo, similarmente se reformularia a perspectiva de leitura da nova capital e aqui repousa a ótica que abriria caminhos para esta dissertação: para além das operações dicotômicas em que Goiânia se imantava de modernidade e que, ao mesmo tempo, repelia um suposto arcaísmo presente em representações pregressas - representações essas que, por sua vez, sistematicamente se associariam a Cidade de Goiás -, uma produção mais atual vem sinalizando que a própria cidade de Goiânia seria interpretada a partir de apreensões duais, sobretudo em seu período inicial. De acordo com Sandes e Arrais (2014), estudos mais recentes indicam que o sentido moderno da jovem cidade pouco transparecia para muitos que a visitavam nos anos de 1930 e 1940, dadas as particularidades de um núcleo ainda em formação. Em suma, "Goiânia resumiria a convivência do atraso com a modernidade" (CHAUL, 1997/2010, p. 269). 
Nesse sentido, muito embora associada às principais marcas do planejamento urbano moderno, a elaboração e a construção da cidade apresentaram fissuras, condicionamentos, adequações e arranjos típicos de um espaço repleto de tensões sociais. O espaço público se estruturava na fronteira com o domínio privado, possibilitando observar, para além do discurso racional, a efetivação de práticas políticas pouco diferentes daquelas anteriores ao movimento revolucionário. As múltiplas temporalidades, escondidas sob o discurso modernizador, revelavam práticas sociais, usos e costumes que negavam a imagem de cidade-capital [...]. (SANDES; ARRAIS, 2014, p. 408)

Sob este prisma, abrigam-se distintas abordagens. Em Imagens e mudança cultural em Goiânia, E. C. de Oliveira (1999) lançaria mão de elementos textuais (documentos oficiais, obras acadêmicas, literárias, dentre outros) para compreender os variados e cambiantes olhares sobre a nova capital. Ao ponderar que a cidade é um meio de ambiguidades e que não basta considerar apenas seus aspectos materiais - visto que as cidades são formadas por pessoas -, o autor afirmaria que Goiânia detinha uma faceta provinciana que só passaria a atenuar-se a partir da década de 1960 (OLIVEIRA, E. C., 1999). O mesmo adjetivo também seria empregado por L. S. D. da Silva (2000), ao apontar as possibilidades de se contar outras histórias da capital goiana.

Já em Goiânia: uma modernidade possível, Gonçalves (2002, p. 163) expunha desde o título uma expressão que, para ele, melhor caracterizaria o momento de idealização da cidade, "fruto de um pensamento intelectual sintonizado com os grandes centros do país e ao mesmo tempo consciente da realidade vivida na fronteira". Se a modernidade irrompia através de uma cidade planejada, os limites desta modernidade residiriam na incompletude de sua plena realização, permeada por precoces reorientações e carências de planejamento.

Sobre o lastro dos demais trabalhos, pode-se ainda citar Utopia e realismo: a construção narrativa sobre Goiânia na década de 1940 (SILVA, L. O., 2014). Através da literatura e da imprensa, o autor recupera os discursos que povoam a matriz historiográfica mais consolidada e, paralelamente, identifica a presença de uma linha narrativa diversa, de caráter cético - que, explicitamente ou não, convivia lado a lado com as narrativas utópicas, por vezes até nas mesmas publicações. Assim, haveria "contradiscursos" que revelariam a existência de uma cidade diferente da idealizada, seja pelos problemas enfrentados, seja pela ótica de interpretação situada num dado tempo presente - e não num porvir (SILVA, L.O, 2014).

Em síntese, as perspectivas habilitam notar que o mesmo espaço urbano da nova capital, em plena formação, era capaz de evocar uma pluralidade de apreensões (que transitavam entre o pitoresco e o moderno, o campestre e o citadino, o rudimento e o progresso), em meio ao crescente distanciamento entre experiências e expectativas. Deste 
modo, visões dissímeis coexistiam na multiplicidade de temporalidades - anacronismos que, de acordo com Lepetit (1993/2016, p. 181), são inerentes às cidades, dado que "o tecido urbano, o comportamento dos citadinos, as políticas de planificação urbanística, econômica ou social desenvolvem-se segundo cronologias diferentes" -, especialmente diante dos particularismos da construção de uma cidade nova ${ }^{2}$. Conforme demonstraremos ao longo da dissertação, estas leituras não se traduzem necessariamente em antíteses binárias e excludentes; suas conexões, na verdade, se dariam de maneira dialógica, mediante simultaneidades e coexistências. Assumimos, portanto, o termo dialética e, sem a pretensão de eleger quais discursos melhor exprimem o quadro de gênese de Goiânia - se é que isso é desejável ou factível -, entendemos ser fundamental compreendê-los, cotejá-los e sobrepô-los pois tais olhares são identificáveis nas formas de leitura feitas por aqueles que interagiam com o ambiente urbano (habitantes, viajantes ou agentes de poder), sendo (re)produzidos, assimilados e cristalizados em vestígios.

A abordagem se desenvolve mediante dois prismas basilares. O primeiro prisma parte da compreensão que a cidade extrapola a noção de artefato. Conforme expõe Meneses (1996), para além da organização espacial das múltiplas estruturas que a compõem, a cidade igualmente é campo de atuação de forças - de natureza econômica, política, territorial, cultural, social - e representação - conceito que abarca a imagem (imaginário, imaginação), tal qual ingredientes como memória, ideologia, classificações, valores, práticas, entre outros ${ }^{3}$. Essas três dimensões se retroalimentam de maneira mútua, estabelecendo-se "solidariamente imbricadas, cada uma dependendo profundamente das demais, em relação simbiótica" (MENESES, 1996, p. 149).

Conquanto indissociáveis nos processos que operam sobre a cidade, tais elementos apresentam diferentes pesos em estudos. Se Le Goff (1978/2011, p. 169) diria, na década de 1970, que "uma dimensão - essencial - que falta ainda em grande parte à história é a do imaginário", tímidas modificações se fariam presentes no cenário da história urbana na década de 1990: naquele momento, segundo Meneses (1996), imperava a dimensão do

\footnotetext{
2 Para definir o termo, Trevisan (2009) classifica-as como conformações que partem dos seguintes atributos: desejo (vontade de agentes, públicos ou não, para concretizar ações específicas), necessidade (atendimento de uma ou mais funções), lugar (escolha prévia de sítio), profissional (existência de agente na elaboração física), projeto urbanístico e tempo (construção significativa numa parcela temporal, envolvendo um momento de fundação razoavelmente preciso).

${ }^{3}$ Chartier (1988/2002), ao retomar as antigas acepções de representação, dispõe que o termo pode pressupor a exibição de uma presença, mas igualmente pode dar a ver uma coisa ausente - onde "a representação é instrumento de um conhecimento mediato que faz ver um objeto ausente através da sua substituição por uma ‘imagem' capaz de o reconstituir em memória e de o figurar tal como ele é” (CHARTIER, 1988/2002, p. 20). É o que Ginzburg (1998/2001) resumiria como oscilação entre a evocação mimética e a substituição.
} 
artefato e o campo de forças vinha tomando corpo sob a influência das ciências sociais, enquanto a representação (ou a imagem) ainda detinha pouco espaço. Quanto ao objeto de estudo, como assinalamos, é preciso destacar avanços nas últimas décadas. Não obstante, se novos e estimulantes caminhos foram abertos, ainda há passos a galgar. A despeito das abordagens críticas à materialidade de Goiânia, percebe-se que ainda há carência de investigações que perscrutem as leituras dialéticas da cidade e seus elementos como integrantes de uma configuração imagética - atuando como agentes ativos de significações não apenas mediante um contato direto e estanque, mas traduzidos e mediados pelas representações. Tais facetas são inerentes às cidades e, sobre a complexa rede de imagens e valorações na qual situa-se o espaço urbano, Argan indicaria:

O espaço figurativo, como demonstrou Francastel, não é feito apenas daquilo que se
vê, mas de infinitas coisas que se sabem e se lembram, de notícias. [...] O espaço
urbano também é um objeto que se pode possuir e que é possuído. Durante muito
tempo, o poder de um senhor foi medido pela quantidade de espaço que ele tinha em
sua posse. Mas a arte, como fenômeno urbano, nada tem a ver com a legitimidade ou
a arbitrariedade dessa posse: o que a produz é a necessidade, para quem vive e age
no espaço, de representar de forma "autêntica ou distorcida" a situação espacial em
que age. O espaço urbano, por fim, é a verdadeira ideologia da burguesia, a
"representação da situação de fato em que age". E dizendo "de fato", diz-se
"imaginário", porque a dimensão em que se projeta e se faz não é certamente o local
em que ocasionalmente nos encontramos, mas a imagem mental que cada um faz do
espaço da vida e que, dado o mesmo fundo de experiência, é a mesma, com exceção
de pequenas diferenças específicas, para todos os indivíduos do mesmo grupo.
(ARGAN, 1969/2005, p. 43-44)

A segunda questão diz respeito às fontes. Embora aqui não se intente estabelecer uma abordagem epistemológica que abarque as complexidades do termo documento ou, ainda, pormenorizar o alargamento de sua noção no âmbito da École des Annales e da chamada revolução documental - visto que há numerosos autores que detêm-se no assunto ${ }^{4}-$, é importante destacar que, diante de uma preocupação metodológica que surge juntamente com esta pesquisa, parte-se da premissa que o documento não se limita àquilo que é estritamente escrito e/ou oficial (algo que talvez soe como intuitivo no que compete à história da arquitetura, da cidade e do urbanismo, dada a não-textualidade de projetos, edifícios e do espaço urbano), bem como da percepção que as fontes são, afinal, testemunhos seletivos, carregados de interpretações e intencionalidades.

Nesse sentido, para além dos "documentos tradicionais" - em especial aqueles que dão corpo a uma consolidada matriz historiográfica de Goiânia -, essa dissertação também se ampara noutro leque documental capaz de subsidiar a compreensão da dimensão cultural da gênese de Goiânia. Dentre eles, podemos citar periódicos, em especial aqueles que circulavam

\footnotetext{
${ }^{4}$ Para aprofundamentos no temário, pode-se consultar obras como de Febvre (1953/1989), Le Goff (1988/1990) e Certeau (1975/2006) ou, ainda, coletâneas como as de Novais e Silva (2011).
} 
contemporaneamente à construção da nova capital, a saber: jornais locais, como O Popular fundado em 1938 pelos irmãos Câmara (dentre eles, Joaquim Câmara Filho, forte agente divulgador de Goiânia, tendo atuado como diretor do Departamento de Propaganda e Expansão Econômica do Estado) - e Folha de Goiaz - jornal fundado em 1939 por Gerson Castro Costa, o autor de Goiânia, a Metrópole do Oeste, e posteriormente adquirido pela cadeia Diários Associados, de Assis Chateubriand ${ }^{5}$; jornais de outros estados, tal como $O$ Estado de S. Paulo, O Globo, Correio da Manhã, A Nação - muitas vezes veiculadores de matérias oficiais e/ou enviadas por correspondentes do Departamento de Propaganda e Expansão Econômica do Estado; e revistas, como Oeste - periódico autodefinido como "revista de divulgação cultural", veiculado entre 1942 e 1944 e cujo corpo de redação era constituído por nomes como Bernardo Élis, Gerson Castro Costa, Zoroastro Artiaga e outros que mencionaremos posteriormente ${ }^{6}$ - e a Revista da Semana - periódico carioca veiculado na primeira metade do século XX, considerado pioneiro na introdução de fotografias em revistas no Brasil (MAUAD, 2005). Este material pôde ser recuperado em acervos físicos como do Arquivo Histórico Estadual de Goiás e da Secretaria Municipal de Planejamento Urbano e Habitação de Goiânia - e digitais - como da Hemeroteca Digital da Biblioteca Nacional e da Folha de S. Paulo.

Podemos citar ainda a utilização de relatos de pioneiros disponíveis em compêndios - como Memórias goianienses, de José Mendonça Teles (1986/2012), e Memória cultural: ensaios da história de um povo, um compilado organizado pela Prefeitura de Goiânia (1985) com depoimentos de advogados, professores, comerciantes, políticos, funcionários públicos e outros habitantes que presenciaram as primeiras décadas da cidade -, acervos - como do Museu da Imagem e do Som de Goiás - e trabalhos acadêmicos.

Ademais, diante das múltiplas visualidades urbanas - privilegiados signos de interpretações e discursos -, a dissertação se faz valer de representações iconográficas (sobretudo as fotografias), elementos fundamentais no processo de construção de Goiânia seja para a divulgação da cidade, seja para a sedimentação de narrativas. Não obstante, à semelhança dos demais documentos, a leitura das fotografias assume a condição parcial destas imagens: se Zicman (1985) indicaria que os periódicos detêm uma orientação, uma vez que a imprensa não registra meramente os acontecimentos - e sim organiza-os de acordo com seu

\footnotetext{
${ }^{5}$ Para mais informações sobre a Folha de Goiaz, ver o artigo Folha de Goiaz: o jornal e o seu tempo, de Enderson Medeiros (2015).

6 Para mais informações sobre a Revista Oeste, ver os artigos A Revista "Oeste": seus intelectuais e a organização da cultura e modernidade em Goiás (1942-1944), de Nepomuceno (2008), A Informação Goyana e Oeste e as estratégias para uma nova civilidade em Goiás (1917-1944), de Peres (2012) e Goiânia, a metrópole do sertão: representações visuais da capital goiana na Revista Oeste, deste autor (GUIMARÃES, 2018).
} 
filtro -, sobre as fotografias Kossoy (1988/2014, p. 121) alertaria que deve-se compreender que o "assunto registrado mostra apenas um fragmento de realidade, um e só um enfoque da realidade passada”. Burke (2001/2004, p. 106), por exemplo, apontaria que a partir de determinadas "atitudes políticas, os fotógrafos escolhiam representar as casas mais deterioradas, a fim de apoiar a campanha pela extinção de cortiços, ou as de melhor aparência, para se oporem a isto" - e, nesta linha, permite-se recordar a atuação do fotógrafo Charles Marville, oficialmente incumbido de registrar a cidade de Paris com objetivo de justificar as grandes intervenções do século XIX e, ao mesmo tempo, perpetuar suas antigas vistas. Deste modo, a fotografia afirma-se como agente ativo em lógicas discursivas.

Aqui se realça também um importante aspecto: a simbiótica relação estabelecida entre a fotografia e a cidade - algo sintomático, indício da mesma interligação intrínseca que se dá entre a cidade e suas representações. Panerai (1999/2006) afirma que a apreensão da cidade é moldada pela representação que delas nos dão, entre outros, as imagens fotográficas. Com efeito, de acordo com Lima e Ferraz (1997/2008), os temários urbanos e arquitetônicos são recorrentemente representados por meio das fotografias desde sua invenção, no século XIX. Para recuperar mais alguns casos, pode-se lembrar que em meio às reformas empreendidas por Haussmann, em Paris promulgou-se uma lei que institucionalizava a documentação fotográfica como um serviço de utilidade pública (COSTA; SILVA, 1995/2004). No Brasil, similarmente, Pereira Passos contrataria o fotógrafo Augusto Malta "que durante décadas, já no início do século XX, registrou o desaparecimento da cidade colonial" (COSTA; SILVA, 1995/2004, p. 19) -, assim como Saturnino de Brito delegaria a um profissional o encargo de documentar as vultuosas obras de saneamento em Santos, num momento que vivenciava-se "uma efetiva transformação da imagem da cidade de traços coloniais, causando um impacto sem precedentes na vida urbana local” (ANDRADE, 1992, p. 142). Não coincidentemente, esses casos guardam características em comum.

Historicamente, linha de regra geral, é possível afirmar que o auge da estética
documental ocorreu no período em que se realizaram as maiores alterações no meio
ambiente social. Ou seja: a duração da estética documental demarca a dinâmica das
transformações que a burguesia operava na natureza. No Brasil, os maiores
fotógrafos documentaristas atuaram justamente na época em que nossas cidades
mais se modificaram. (COSTA; SILVA, 1995/2004, p. 19)

Em movimentos de profundas mudanças urbanas, para além dos planos de remodelação e embelezamento em cidades consolidadas, também se notam iniciativas com o intuito de registrar a construção de novas cidades. É possível listar, por exemplo, casos como o de La Plata - e os álbuns fotográficos de Tomás Bradley - e Belo Horizonte - onde as fotografias eram produzidas por profissionais do Gabinete Fotográfico da Comissão 
Construtora da Nova Capital, agrupadas em exemplares como o Album de vistas locaes e das obras projectadas. Segundo Arruda (2011/2013, p. 23), a confecção de plantas, álbuns fotográficos e cartões-postais destas duas cidades exprimem apropriações de uma cultura visual circulante em nível global, onde as imagens "foram mobilizadas como recurso técnico, como meio de propaganda, como forma de criar memória, idealizar sujeitos e espaços”. E ainda, conquanto integrante de uma outra temporalidade (com distintas linguagens ${ }^{7}$ ), convém elencar Brasília, fartamente documentada por lentes como as de Marcel Gautherot - ou, para citar pratas da casa, Hélio de Oliveira.

De modo análogo, Goiânia se situa neste universo. Conforme a construção avançava, planos e fotografias da cidade multiplicavam-se e difundiam-se para exibir o acelerado ritmo no qual a cidade surgia. A maior parte dessas fotografias provém dos chamados fotógrafos pioneiros, tais como Antônio Pereira Silva (Foto Silva), João de Paula Teixeira Filho (Foto Paratéca), Haroutium Berberian (Foto HB), Eduardo Bilemjian (Goiânia Foto), Sílvio Berto (Foto Berto e A Fotográfica), Alois Feichtenberger, dentre outros. E conquanto não se possa pressupor que todas as imagens sempre tivessem larga circulação contemporaneamente à construção da capital (ou que sempre alcançassem amplas camadas daqueles que vivenciavam a cidade), diversos meios de comunicação da época abundantemente utilizavam fotografias de Goiânia - dentre eles, os periódicos e livros citados até aqui.

Era comum, ainda, a produção de vistas e álbuns fotográficos, confeccionados para comercialização (como uma espécie de souvenir) e/ou para divulgação do empreendimento. Pode-se citar, por exemplo, o Álbum de Fotografias sobre o Planejamento e Construção da Cidade de Goiânia - uma coletânea com 78 pranchas de textos, mapas e fotografias de Goiânia, Cidade de Goiás e paisagens do estado, encomendado pelo interventor Pedro Ludovico para presentear o presidente Getúlio Vargas, nos fins de 1937 -, o Álbum de Goiaz - um compêndio de 276 páginas editado pelo jornalista Orlando Barbosa que, entre fotografias de animais, eventos culturais e vistas de cidades goianas, traria numerosos registros de Goiânia - e os álbuns Goiânia: uma cidade por decreto e Lembranças de Goiânia: "a capital caçula” - confeccionados por Haroutium Berberian e Sílvio Berto, respectivamente. Tais acervos puderam ser acessados em instituições públicas como Museu

\footnotetext{
${ }^{7}$ Naquele momento, outras estéticas além da documental popularizavam-se, ao mesmo tempo que produções como de Gautherot distinguiam-se das fotografias de artistas concretos e neoconcretos da época. De acordo com Espada (2011, p. 10), “ao invés das formas planas apresentadas com franqueza e dos jogos ópticos estimulando sensações de velocidade e movimento, as fotos de Gautherot mostram paisagens em que a ilusão de profundidade é criada por perspectivas proeminentes e formas modeladas cuidadosamente em chiaroscuro".
} 
da Imagem e do Som de Goiás e Secretaria Municipal de Planejamento Urbano e Habitação de Goiânia.

Diante deste corpus documental, é importante destacar que, naturalmente, a questão das fontes não se encerra em si. Em essência, o objetivo central da dissertação, com suas devidas limitações, não é arraigar-se no temário fotográfico ou, ainda, estabelecer um estudo sistematizado dos veículos de comunicação goianienses. Com o aporte de tais documentos na condição de meios de leitura da sociedade, intenta-se, sim, vislumbrar representações que, socialmente, atuavam no quadro de gênese da cidade.

Sem embargo, em meio às diversas contribuições recentes, não deixa de ser curioso notar a subsistência de um descolamento entre o protagonismo das fotografias no processo de consolidação física e simbólica de Goiânia e a quantidade e diversidade de estudos que se detêm sobre esse prisma, hoje ainda reduzidas. Grande parte das publicações pioneiras, por exemplo, substancialmente compõe-se por fotografias que exprimem mensagens e, mesmo assim, quase não há menções acerca dessa fonte documental nas obras que versam sobre a historiografia goiana e goianiense - mesmo naquelas pesquisas mais recentes já $\operatorname{citadas}^{8}$. Nos raros casos, comumente limitam-se a uma condição já descrita por Burke:

Quando utilizam imagens, os historiadores tendem a tratá-las como meras ilustrações, reproduzindo-as nos livros sem comentários. Nos casos em que as imagens são discutidas no texto, essa evidência é frequentemente utilizada para ilustrar conclusões a que o autor já havia chegado por outros meios, em vez de oferecer novas respostas ou suscitar novas questões (BURKE, 2001/2004, p. 12)

Reduzir estas lacunas, então, significa expandir o entendimento acerca das produções de sentido - estabelecidas a partir do diálogo entre textos (ou imagens) e leitores, no que Chartier (1988/2002, p. 26) classificaria como uma "relação móvel, diferenciada, dependente das variações, simultâneas ou separadas, do próprio texto, da passagem à impressão que o dá

\footnotetext{
${ }^{8}$ É necessário registrar que não se trata de um ambiente inerte. Há relevantes aportes ao viés fotográfico, como a série de cadernos publicados pelo Museu da Imagem e do Som de Goiás. Dentre eles, pode-se citar O Fotógrafo Sílvio Berto (MUSEU DA IMAGEM E SOM DE GOIÁS, 2001) e Pioneiros da fotografia em Goiânia (MUSEU DA IMAGEM E DO SOM DE GOIÁS, 2002). A última obra, principalmente, é importante por concatenar uma longa pesquisa empreendida pela instituição, cujo produto resultou no mapeamento de 12 fotógrafos pioneiros isto é, primeiros fotógrafos que, integrantes do contingente de trabalhadores atraídos pelas oportunidades da nova cidade, montaram seus estúdios "no período de construção de Goiânia, de 1933 a 1950" (MUSEU DA IMAGEM E DO SOM DE GOIÁS, 2002, p. 7) -, responsáveis por majoritária parcela da documentação visual das primeiras décadas da nova capital. Sobre este eixo, outros estudos também podem ser elencados. Trabalhos como O pioneiro Sílvio Berto: fotografia e sociabilidade (NUNES, 2001), A fotografia em Goiânia nas primeiras décadas do século XX (MONTEIRO, R. H., 2008), Memória e identidade de um bairro: Campinas sob as lentes de Hélio de Oliveira (TITO, 2008) e A "modernidade múltipla" brasileira na trajetória do fotógrafo Alois Feichtenberger (OLIVEIRA, G. T., 2018) são capazes de fornecer relevantes contributos historiográficos por meio de ângulos distintos. Todavia, a síntese bibliográfica revela que tende-se a privilegiar abordagens a partir da lente de um fotógrafo em detrimento de um olhar alargado sobre as visualidades da cidade - o que logicamente não minimiza a expressividade de suas contribuições - e, diante deste quadro, ainda há poucos casos que se baseiam numa iconosfera mais ampla, como a abordagem de K. M. Silva (2006/2012).
} 
a ler e da modalidade da sua leitura" - que matizariam a cidade. Imersa nessa ótica, a dissertação propõe compreender como as leituras acerca de Goiânia, traduzidas e mediadas por representações que transitavam entre o "arcaico" e o moderno, seriam capazes de consolidar (ou moldar, conforme as relações de poder) os discursos dialéticos - e, numa relação mútua, como os discursos também reverberariam na conformação e apreensão da cidade.

Para tal, compreendendo que a organização de capítulos segundo determinadas categorias antitéticas e estanques (como cidade provinciana e cidade metrópole, ou narrativas utópicas e narrativas realistas) corroboram o distanciamento de temporalidades coexistentes, optamos por estruturar a dissertação a partir de três "momentos" da construção da nova capital: a ideia, a obra e a concretude - que, embora sinalizem a existência de um nexo cronológico, não pressupõem a ausência de amplas sobreposições e concomitâncias entre si.

O primeiro capítulo, Cidade-ideia, diz respeito a uma cidade em concepção. Em que pese seus contornos de viabilidade se maturarem a partir da década de 1930, abordar a idealização de Goiânia implica situá-la num quadro de (re)construções identitárias em âmbito nacional e local que, fundamentalmente, envolvem representações pregressas de Goiás representações essas que encontrariam reverberação na nova capital, seja como resquício de um olhar sedimentado, sejam como discursos a serem contrapostos num movimento de reorientação. Concerne à cidade-ideia, também, o engendramento dos discursos que justificariam a transferência da capital, bem como as feições idealizadas para a cidade, num momento em que o urbanismo galgava um crescente espaço como campo de reflexão e atuação profissional.

O segundo capítulo, Cidade-obra, se refere à cidade em vias de concretização, onde a acelerada cadência da empreitada já delinearia a nova capital como uma realidade quase inevitável. Os discursos, textuais ou não, pareceriam ratificar que o progresso gradualmente passava da retórica à materialidade mediante um cenário que remeteria a um grande canteiro de obras, carregado de profundas transformações - seja no "terreno virgem" onde se implantava Goiânia, seja na pequena cidade vizinha de Campinas. Essa passagem seria conduzida pelos homens da técnica e da política, mas também por inúmeros anônimos, sobretudo os operários, representação da força-motriz que alimentava a consolidação daquele sonho. Entretanto, num quadro permeado de vicissitudes, a cidade-obra carregaria consigo simultaneamente as imagens de progresso e as imagens de carências, diante das possibilidades e dos limites que envolviam a implantação de uma cidade moderna em pleno sertão. 
Por fim, o terceiro capítulo, Cidade-concretude, versa sobre uma cidade que, em princípio, confirmaria as expectativas que permeavam a idealização da cidade-ideia conquanto o estado de concretude não necessariamente implicasse na integralidade de um processo de estabelecimento. A modernidade e a modernização apreensíveis - ou pelo menos esboçadas - impressionariam muitos daqueles que vivenciavam a nova capital, entre moradores e visitantes, de modo que Goiânia aparentaria se dispor inteiramente no polo do progresso, nos moldes de alguns dos discursos que lhe deram origem. Todavia, concomitantemente, muitos outros se decepcionariam diante de uma urbe repleta de ambivalências, de sorte que na nova capital se apreenderia distintas facetas que, no limiar dos signos do passado e do futuro, dialogariam profusamente. A cidade e seus elementos, por conseguinte, sinalizariam metáforas que muito dizem sobre aquelas décadas de profundas amálgamas em Goiás, mas também em diversas outras escalas geográficas. 
Cidade-ideia 


\section{CIDADE-IDEIA}

\subsection{Identidades em (re)construção}

Se alguns exemplares dos meus relatos resistirem ao tempo e ao esquecimento, as gerações futuras talvez encontrem neles informações de grande interesse sobre essas vastas províncias, provavelmente transformadas, então, em verdadeiros impérios. E ficarão surpreendidas ao verificarem que, nos locais onde se erguerão então cidades prósperas e populosas, havia outrora apenas um ou dois casebres que pouco diferiam das choças dos selvagens; que onde estão retinindo nos ares os ruídos dos martelos e das máquinas mais complexas ouviam-se apenas, em outros tempos, o coaxar de alguns sapos e o canto de pássaros; que, em lugar das extensas plantações de milho, de mandioca, de cana-de-açúcar, e das árvores frutíferas, o que havia eram terras cobertas por uma vegetação exuberante mas inútil. (SAINT-HILAIRE, 1848/1975, p. 14)

Após percorrer as vastidões do interior do Brasil no primeiro quartel do século XIX, Auguste de Saint-Hilaire (1848/1975) registraria parte de suas impressões em Viagem à Província de Goiás, a qual introduziria com uma espécie de predição. A despeito da inércia que aparentava assolar aqueles rincões, ao passo que a extrema vagareza das mudanças parecia tornar imperceptível qualquer sinal de progresso, o francês anunciaria um porvir que, embora longínquo, se apresentava quase como inevitável: sobre aquelas belas regiões desérticas avançaria a civilização, com suas urbes florescentes, estradas de ferro e amplos cultivos.

Diante do que antevira, possivelmente Saint-Hilaire não se surpreenderia com o que adiante se vislumbraria naqueles sertões, mas talvez se admirasse ao saber que muito daquilo que escrevera no prefácio se esboçaria menos de um século depois da publicação de seus relatos. A ferrovia, uma idealização antiga para Goiás, finalmente cruzaria o Rio Paranaíba na Primeira República, marcando a expectativa de um dinamismo que seria capaz de romper o quadro de isolamento que, por séculos, se atribuía ao estado. A estrada de ferro, por sua vez, urgia como corolário das crescentes necessidades de integração na lógica de produção mercantil visto que, conforme aumentavam os preços das terras no Centro-Sul do Brasil em face da cultura cafeeira e, ainda, com a aceleração do ritmo de crescimento urbano e industrial, tornava-se cada vez mais atrativo o desenvolvimento da agropecuária em solo goiano (CHAUL, 1997/2010).

Em meio às vicissitudes de um processo difuso e gradual, no entanto, é a concretude da nova capital de Goiás que eminentemente prefigura os sinais de uma dinâmica distinta uma vez que, segundo Lepetit (1996), o urbano é um privilegiado observatório onde as hierarquias se afirmam de forma mais refinada e estruturada, e onde se evidenciam relações explicativas que, de outro modo, poderiam passar despercebidas à medida se dispõem bastante distendidas para serem assimiladas. Em Goiânia, portanto, se verificaria o cumprimento do vaticínio de 
Auguste de Saint-Hilaire - conforme indicaria Luís Gonzaga de Fonseca (1943, p. 25) num artigo à Revista Oeste -, diante do surgimento de uma metrópole que traria consigo todas as possibilidades "de irradiar um ciclo novo de civilização sobre o Estado inteiro, e quiçá sobre todo o centro do Continente".

Precedentemente à concretude da nova capital, todavia, encontra-se sua idealização numa operação que, longe de ser essencialmente objetiva, é permeada por anseios, expectativas e interlocuções. Como sugere Rama (1984/1998, p. 23), se "em vez de representar a coisa já existente mediante signos, estes se encarregam de representar o sonho da coisa", a cidade, antes de qualquer materialidade (mas também durante e depois), iminentemente estabelece-se num campo simbólico através de palavras, imagens mentais, diagramas e planos. Depreender a construção de Goiânia em sua complexidade pressupõe, então, engendrar a leitura a partir do quadro dialógico na qual a urbe é gestada. É sobre essa cidade ainda em concepção, a cidade-ideia, que se dispõe assim nosso primeiro olhar.

A princípio, mais que inserir o objeto de estudo numa perspectiva cronológica, a recuperação de marcos temporais permite revelar determinados sentidos atribuídos à nova capital. O lançamento de sua pedra fundamental, por exemplo, ocorre em 24 de outubro de 1933 - não coincidentemente, exatos três anos após a deposição de Washington Luís. Similarmente, a inauguração oficial de Goiânia, o chamado Batismo Cultural, realiza-se em 5 de julho de 1942 - rigorosamente no bidecênio da Revolta dos 18 do Forte de Copacabana e no aniversário de 18 anos da Revolução Paulista de 1924, ambas no bojo do Tenentismo. Decorrência direta de 1930 e imersa nesta nebulosa de eventos atrelados à "revolução", por conseguinte, Goiânia seria vista como a cristalização revolucionária, a materialização do desejo de renovação e remodelação (5 DE..., 1944) - repleta de alusões a episódios que, de certa forma, contribuiriam para seu estabelecimento.

Goiânia é 1922, é 1924, é 1930 e 1937. Capital revolucionária, nascida de um anseio revolucionário, de um desejo veemente de emancipação dos péssimos costumes políticos liberais. Goiânia incarna, em toda latitude, o cinco de julho. E foi em um cinco de julho, cheio de luz e de harmonia, que Goiânia se integrou no rol da família das cidades brasileiras. (5 DE..., 1944, p. 6)

Logo, independentemente do mérito sobre o quão renovador possa ter sido efetivamente esse movimento no estado - à medida que, em Goiás, não se verificaria necessariamente uma estrita regionalização do plano nacional de governo, "mas sim uma

\footnotetext{
${ }^{9}$ L. Martins (1983) aponta que a manutenção do termo "revolução" parece justificar-se pela percepção de seus reflexos como indicadores de "rupturas". Entretanto, segundo o autor, não há ruptura, e sim "um método extremo de negociação de conflitos entre elites" (MARTINS, L., 1983, p. 678), onde não se questionava a oligarquia como classe dominante.
} 
adequação destes com as ainda presentes forças 'conservadoras' das oligarquias estaduais" (ARRAIS, 2007, p. 834) -, destaca-se que a nomeação do interventor Pedro Ludovico Teixeira por Getúlio Vargas marcaria um processo de distinção mediante reorientações político-ideológicas que, pautadas pelo progresso, seriam articuladas principalmente como meio de diferir os grupos ascendentes dos grupos depostos (CHAUL, 1997/2010). Diante deste quadro é que a construção de uma nova capital, fixada como signo maior do afã por modernização, torna-se a principal bandeira encampada pelo governo local, em meio ao campo de batalha simbólico que se estabelece.

Entretanto, para além da brevidade dos acontecimentos - o que Braudel (1958/2011, p. 91) definiria como "tempo curto, aquele cuja medida é a dos indivíduos, a da vida cotidiana, a de nossas ilusões, nossas rápidas tomadas de consciência” -, convém indicar que, conquanto seja no pós-1930 que a ideia de uma nova sede administrativa para Goiás encontre lastro suficientemente propício para ser viabilizada, a concepção de Goiânia dialoga profusamente com representações cujos limites escapam às molduras da década na qual é fundada. Afinal, se Castro Costa (1942, p. 3) diria que para "localizar a significação ideológica da edificação da cidade de Goiânia, somos obrigados a volver os olhos para o passado, para as quadras aventurosas das bandeiras", deste mesmo passado advêm as visões de decadência, atraso e vazio, estigmas que matizariam Goiás ao longo do tempo e que permaneceriam manifestos no século $\mathrm{XX}$ - reverberando na trama discursiva da gênese da capital, seja como resquício de uma imagem sedimentada, seja como uma memória a ser questionada, em especial por conta das novas relações de forças.

Em Caminhos de Goiás: da construção da decadência aos limites da modernidade, Chaul (1997/2010) fornece subsídios para compreender tais relações. Para o autor, se tudo se iniciaria com o ouro (diante de um passado pré-aurífero comumente negligenciado), com o ouro igualmente tudo acabaria pois, de maneira antagônica à opulência de um período supostamente glorioso (e aí também reside o mito do herói bandeirante, descobridor de riquezas no âmago do país), a transição para algo que paulatinamente passa-se a afirmar como crise fixaria um longevo cenário de estagnação e isolamento. Do esgotamento aurífero se construiria a decadência, delegada à identidade através de juízos de viajantes e membros da administração.

Inúmeros viajantes europeus produziram relatos que descreveram o estado de empobrecimento da região, e mesmo a elite política corroborava o estado de decadência em que Goiás se encontrava. Os viajantes e cronistas registraram o que seus olhos puderam ver e constatar: o empobrecimento e isolamento da região. Essas mesmas impressões são compartilhadas pelos homens da elite local, sem que outro olhar indicasse uma representação diversa daquele mundo. Essa memória insular, na 
forma de estigma, conduziu as ações sociais formadoras da identidade local. (SANDES, 2002, p. 19)

De fato, dentre as obras de autores decimonônicos que versam sobre Goiás, a perspectiva é continuamente destacada. O britânico George Gardner (1846/1975), por exemplo, indicaria ter ouvido sobre a considerável quantidade do metal nos arredores de um assentamento em outros tempos, embora o pouco que ainda existisse mal fosse capaz de pagar as despesas do labor. Essa lembrança de tempos melhores também aparece nos relatos de Johann Emanuel Pohl (1832/1951), que se detém no assunto:

Maiores lucros deram, outrora, as minas de ouro, hoje inteiramente decaídas. Agora
estão esburacados os bancos de areia dos rios de todos os lugares e a superfície da
terra faltam braços para explorar o que resta ou minas novas. As lendas das riquezas,
que os habitantes outrora desse modo extraíam da terra, chegam ao anedótico,
limitam com o fabuloso. (POHL, 1832/1951, p. 295)

Já o português Raymundo da Cunha Mattos (1874/1979, p. 79), em descrições destinadas ao então Imperador D. Pedro I, afirmaria que se "a sede de ouro foi a causa da descoberta de Goiás, e a esperança do ouro tem sido causa de sua ruína” dado que, mesmo com a escassez aurífera, muitos ainda esperavam enriquecer através da mineração - e por isso não desenvolveriam o verdadeiro potencial econômico da região, sobretudo a partir da agricultura e da pecuária, alternativas que seriam igualmente apontadas por Pohl (1832/1951) e Saint-Hilaire (1848/1975). Neste quadro, as impressões constantemente aludiriam a uma situação de extrema escassez.

Sob mesma lógica, é notável como tais representações se apresentam mesmo em textos datados no século seguinte. Prado Jr. (1942/2011), por exemplo, se apoiaria no próprio Cunha Mattos para assinalar o princípio da decadência de Goiás - que remeteria pelo menos ao terceiro quartel do século XVIII. Segundo o autor, com o esgotamento de sua única riqueza - o ouro -, logo a capitania passaria a encontrar-se num longo e profundo estado de decomposição econômica e social (PRADO JR., 1942/2011).

Em essência, o que se veria em Goiás seria o oposto do progresso. E diante da percepção da falta de estímulos, nos relatos apareceria quase uníssono o juízo de que o interior do Brasil se encontraria incomparavelmente atrasado em termos de civilização mesmo se observado à luz de outras regiões consideradas similarmente carentes, segundo advertência do ítalo-britânico Savage-Landor (1913). Imerso no mesmo campo semântico da decadência (e com ela por vezes confundindo-se), destarte, se situaria o atraso que, não estanque, seria uma espécie de derivação ou correlação daquela primeira (CHAUL, 1997/2010). 
Conquanto a expressão posteriormente assuma um viés específico ao ser também adotada para definir práticas políticas da Primeira República, em particular destaca-se a acepção de atraso como categoria "de desejabilidades ou de esperanças frustradas" relacionada ao tempo das expectativas e metas - nos termos de Koselleck (2000/2014, p. 163). Tais representações de atraso, assim, concerniriam à carência de um pressuposto desenvolvimento, como conotaria Cunha Mattos (1874/1979) ao discorrer sobre a indústria de Goiás no século XIX. Mais tarde, já em meio às discussões sobre a transferência da capital, Armando Augusto de Godoy (1933/1943) empregaria no relatório apresentado ao interventor Pedro Ludovico o mesmo sentido. O atraso de Goiás, para o engenheiro, se daria em razão da ausência de uma cidade moderna e de sua decorrente influência civilizadora.

Atribuo o pouco ponderável progresso do vosso Estado, ao fato de nele ainda não ter
podido surgir um centro urbano com todos os elementos necessários para se
expandirem e estimularem as múltiplas atividades que caracterizam a vida
econômica e social de um povo. Esta necessidade se vem impondo há muito tempo e
vós e outros goianos ilustres, bem como vários homens importantes que visitaram
Goiás, compreenderam que já não se pode adiar a solução de tal problema, tão
premente ele se apresenta. (GODOY, 1933/1943, p. 213)

Para além das representações de decadência e atraso apontadas por Chaul (1997/2010), ainda convém mencionar o vazio, outra chave de leitura que, de modo semelhante, permearia as apreensões da região. Pois, se Rama (1984/1998) aduziria sua manifestação de forma sui generis na América - em face do mito do continente novo, onde a ocupação de suas imensas extensões de "terras virgens" se dispunha não só como oportuno ou necessário, mas também como algo praticamente irremissível -, chama atenção como a categoria assume uma dimensão própria no centro do Brasil, sobretudo ante a especificidades da colonização portuguesa. Frequentemente posto como antagônico à apropriação costeira, portanto, o vazio encontraria no âmago do país um terreno fértil para sua sedimentação no imaginário, sendo evocado por meio de numerosos termos - interior, oeste, hinterland, sertão, dentre outras categorias socioespaciais de limites fluídos e significados múltiplos.

Sob esse prisma, as leituras sobre Goiás remeteriam a um local longínquo, isolado e de ocupação rarefeita. O britânico John Mawe (1812/1978) indicaria que, embora sua população estivesse inclinada a aumentar, ainda era pouco expressiva diante da dimensão de seu território - território esse que, por estar tão afastado do litoral, seria muito pouco explorado. Já Saint-Hilaire (1848/1975), ao incorporar o termo "sertão" em seus relatos, apontaria que aquelas regiões vastas e exiguamente ocupadas estariam entregues à própria sorte, dada a falta de estímulos ou aspirações - apesar do francês lá perceber os embriões de uma grande prosperidade. Outrossim, à maneira da decadência e do atraso, as impressões do 
vazio se perpetuariam mesmo contemporaneamente à construção de Goiânia - como sugeriria Sérgio Buarque de Holanda (1936/1995, p. 101) no célebre capítulo O semeador e o ladrilhador, ao sinalizar que "quando hoje se fala em 'interior', pensa-se, como no século XVI, em região escassamente povoada".

A decadência, o atraso e o vazio que, como visto, se atribuiria a Goiás, presumivelmente não devem ser assumidos em absoluto. Na verdade, é preciso estabelecer uma leitura contemporizada dessas categorias, conforme apontam determinadas perspectivas revisionistas. Sendo assim, Chaul (1997/2010, p. 268) sintetizou que Goiás não seria necessariamente decadente ou atrasado, "apenas caminhava de acordo com suas possibilidades, no ritmo estabelecido pelo lugar que ocupava no conjunto da sociedade brasileira" - e não no compasso das sociedades europeias. Aliás, muitas das visões negativadas maturam-se justamente a partir do olhar de viajantes cujas referências eram alheias à realidade local, através de padrões externos - como paradoxalmente já alertaria Saint-Hilaire (1848/1975). Concomitantemente, percebe-se o emprego do "discurso da exageração" para fins governamentais, ao passo que os relatórios de membros de administração continuamente apresentariam um cenário de carência e estagnação "como parte de uma estratégia política que visava a inclusão da província nas preocupações do Estado" de acordo com Sandes (2002, p. 22) que, para exemplificar, recuperaria um alerta nos relatos de Cunha Mattos.

Falta um poderoso braço que tire o povo da apatia em que se conserva: falta restabelecer e restaurar a boa fé nos comerciantes; falta obrigar os homens aos trabalhos da agricultura; falta compeli-los a empregarem-se na navegação; falta dar nova vida as construções de grandes barcas chatas mui diferentes, e com aparelhos diversos daqueles de que usavam nas passagens perigosas dos rios; falta conservar e desobstruir as estradas e abrir outras mais diretas e mais cômodas; falta reformar as pontes agora arruinadas, e as que antigamente existiam; falta dar prêmios aos maiores exportadores, e tirar os embaraços aos importadores [...] em conclusão, falta quase tudo para dar algum vigor ao comércio da comarca de Goiás; mas os elementos existem na província: nada se carece de fora dela; nada é impossível, uma vez que possível for ressuscitar ou criar algum patriotismo no coração dos governantes e governados. (MATTOS, R. J. C., 1874/1979, p. 69-70)

Similarmente se dispunha o vazio que, para além da "herança da violência fundadora" - expressão que se empresta de Ricoeur (2000/2007, p. 95) -, também advinha de um prisma que pouco consideraria as especificidades locais. Logo, apesar de persistentemente verificar-se uma baixa densidade demográfica do estado, não deixa de chamar atenção que o progressivo quadro de expansão e dinamização das atividades agropecuárias ou, ainda, de adensamento da rede urbana de Goiás - mesmo anteriormente à fundação de Goiânia ou a um 
efetivo despertar da industrialização ${ }^{10}$ - pouco corresponderia às hiperbólicas imagens de uma região absolutamente agreste.

Naturalmente não nos cabe deter numa aprofundada leitura sobre representações atinentes a escalas mais amplas. Todavia, sem a pretensão de esgotar um temário cuja complexidade escapa aos limites (e ao escopo) desta dissertação, as categorias perpassadas até aqui possibilitam apreender a sedimentação de determinadas dialéticas que, multiformemente presentes ao longo do tempo, se manifestariam no processo de concepção e consolidação física e discursiva da nova capital - particularmente em meio às operações reorientativas nas quais Goiânia se insere. Diante do esforço de reversão de uma memória histórica estigmatizada, Goiânia seria a cristalização (e, concomitantemente, agente catalisador) de novos sentidos identitários gradativamente imbuídos não apenas ao âmbito regional, mas também nacionalmente.

O florescimento de discursos regionalistas e a busca por uma interpretação do Brasil prefigurariam alguns desses pontos de inflexão, ao estabelecerem uma inserção distinta para o interior do país. Obras literárias como Os Sertões de Euclides da Cunha (1902/2010) - e, para citar pratas da casa, Tropas e Boiadas de Hugo de Carvalho Ramos (1917/1922) -, seriam capazes de sinalizar que, conquanto ainda parecesse permanecer às margens dos processos civilizatórios, o sertão deixaria de ser classificado como locus de degeneração - apenas se encontraria apartado por uma dita assincronia temporal, sempre em vias de ser rompida pela voraz marcha do progresso. E que, diferentemente do "litoral, em que se refletia a decadência da metrópole e todos os vícios de uma nacionalidade em decomposição insanável” (CUNHA, 1902/2010, p. 70), nos rincões do país se encontraria o cerne da verdadeira identidade nacional, com deficiências e virtudes presentes num estado de exacerbação. Mais que "redescobrir" a região, "redescobria-se" o Brasil.

Com efeito, os homens da primeira geração republicana brasileira, os homens
nascidos na passagem do século XIX para o XX, conseguiram redescobrir o Brasil
no sertão. Musicólogos como Mário de Andrade e Villa-Lobos, indianistas como
Cândido Rondon, ensaístas, sociólogos e historiadores como Sérgio Buarque de
Holanda, sanitaristas como Carlos Chagas e Belisário Pena, militares como os
tenentes da Coluna Prestes, são os responsáveis por um movimento quase sempre on
the road de questionamento e transformação das atitudes, concepções e sistemas

${ }^{10}$ F. de Oliveira (1982/2013) indicaria que, diante de um senso comum que estabelece a urbanização na sociedade e na economia brasileira como fenômeno irrompido somente a partir da industrialização, usualmente pretere-se as particularidades da formação urbana dentro do quadro de uma economia agroexportadora, em especial anteriormente à década de 1930. Neste sentido, ao deixar de considerar "o caráter dessa urbanização como o centro do capital comercial e de todas as atividades ligadas a ela, dificilmente se pode entender o fato de que a urbanização no Brasil, desde a colônia e principalmente no século XIX, avança a passos mais largos do que aqueles que nos acostumamos a entender" (OLIVEIRA, F., 1982/2013, p. 50) - o que em Goiás pode ser constatado a partir da constelação de localidades que surgem, por exemplo, na virada do século XIX para o XX. 
políticos de conduta, movimento construído em torno da ideia de "incorporação dos sertões" e consequente encontro com o outro representado pelo homem brasileiro um personagem invariavelmente visto como isolado, abandonado, doente, nômade, atrasado, resistente a mudanças, despossuído, mas em torno do qual ocorre um processo de redescobrimento constante do Brasil. (SCHWARCZ; STARLING, 2015 , p. 350)

Para Souza (1998), daí decorreria a maturação da noção de fronteira no pensamento social brasileiro, mediante uma nova ambiência de representações sobre o sertão, fruto de inflexões presentes tanto em perspectivas românticas - que exultariam a autenticidade do modo de ser sertanejo - quanto realistas - sobretudo a partir de Euclides da Cunha, cuja compreensão de atraso se dispunha não a partir de algo predeterminado, mas por um estado presente e superável.

Simbolizando um processo de desenvolvimento, a criação de zonas de fronteira é
percebida como uma oportunidade de dissolução de diferenças, quando se realiza a
subordinação do interior-sertão ao modelo civilizatório do litoral. A intenção é que o
preenchimento dos 'vazios' sertanejos pelas atividades da fronteira seja capaz de
forjar um só Brasil que concilie as características políticas do litoral e do sertão. No
pensamento social, os pares litoral-sertão não são reificados e sofrem alternância e
relativização de valor. Desse modo, na fronteira será conciliada a qualidade positiva
do litoral - a civilidade - com a crença de que o interior/o sertão resguarda um
Brasil não contaminado, o lugar de preservação da nacionalidade autêntica. A
fronteira, por tudo isso, resume as esperanças e os projetos de construção de uma
nacionalidade equilibrada e harmonizada no desenvolvimento de suas partes.
(SOUZA, 1998, p. 59)

Uma vez que no âmago do Brasil habitaria nossa pura essência, voltar-se para o centro passaria a significar um gesto autêntico de brasilidade - posteriormente traduzido pelo imperativo "Marcha para o Oeste". Similarmente, a construção de uma metrópole em pleno hinterland representaria um feito sem precedentes (em que pese a criação pregressa de outras novas capitais), apenas comparável ao que se atribuiria como sua pedra angular - a epicidade das incursões bandeirantes, como síntese das glórias desbravadoras, de modo que, não por acaso, o monumento de Bartolomeu Bueno assumiria localização privilegiada na futura cidade. Ademais, se marcaria um movimento de ocupação das imensidões devolutas à medida que, como metaforizaria Getúlio Vargas, o Brasil ainda seria "um arquipélago formado de algumas ilhas entremeadas de espaços vazios" (O OESTE..., 1941, p. 9). Goiânia nasceria, assim, como fruto e símbolo de uma nova consciência arrimada num embasamento antigo, imantada pelo afã de integração nacional a partir da convergência de pares contumazes como norte-sul ou centro-litoral - que, em última instância, trariam consigo dialéticas como sertãocivilização, arcaísmo-modernidade ou estrangeirismo-localismo.

E foi nesse novo clima cultural, substituído o "imitacionismo" pelo "sertanismo", que nasceu Goiânia. [...] De fato: cidade única, no Brasil, pelo que significa, Goiânia se apresenta, no quadro dos valores políticos nacionais, como algo inédito e eloquente. É que ela reatou, planificando-o e sistematizando-o, o jordaneio 
bandeirante, o mais autêntico dos movimentos civilizatórios brasileiros, como já notou alguém. Espelha, a nova metrópole, o ideal pátrio de integridade e de unidade; é um dos atos, o mais positivo talvez, em que se vai objetivando o imperialismo brasileiro; representa a tradução, em termos práticos, da vontade nacional do poder; é o começo indiscutível da prova de que "esta Terra tem dono" [...] Goiânia vale, mais que tudo, como afirmação do valor do homem tropical, eis que revela, de modo inequívoco, a capacidade da gente brasileira. (O DIA..., 1944, p. 1)

Não obstante, entre o despertar dos novos sentidos que se esboçavam para a região, paralelamente aos esforços para o engendramento da nação, e o momento em que a nova capital ganha contornos de materialidade, requer-se um decurso temporal. Nesse intervalo, se verificaria a substancialização de um agente preponderante para o redimensionamento de determinadas operações: o Estado intervencionista, corolário da Revolução de 30 que, à semelhança de vizinhos latino-americanos, se autoatribuiria a incumbência de prover as condições econômicas, territoriais, sociais e culturais para a constituição de uma nova sociedade (GORELIK, 2005). Diante da autodesignada vocação reformadora, conforme paulatinamente se passaria a afirmar que o novo caráter do governo central, "autoritário e centralizador", seria o caminho possível para a construção da nacionalidade (MARTINS, C. A. F., 1987, p. 109) - ou, localmente, a via para tirar de Goiás as marcas do atraso -, destacase a subsistência de um empenho estatal de ordem prática, mas que embebe-se profusamente dessa herança discursiva para alicerçar-se de modo simbólico.

Sobre esse lastro se dispõe o progresso, ponta de lança de Vargas e Ludovico, tanto meio de desenvolvimento material - tão necessário para a atualização do sistema econômico nacional - como elemento aglutinador - em virtude da capacidade unificadora da modernidade (BERMAN, 1982/1986), um estímulo essencial de coesão ante a ampla fragmentação territorial. Outrossim, o progresso concomitantemente se apresentaria em Goiás como gatilho de renovação, a distinção de um novo tempo - quase como se outrora não houvesse qualquer anseio ou gesto em direção à modernização.

Em suma, é deste modo que discursivamente concebe-se o florescimento de um Goiás distinto no pós-1930. De forma análoga ao que se verificaria em outras escalas, ao estado projetava-se um futuro próprio que, paradoxalmente, se estabeleceria em diálogo com um pretérito de feições ambivalentes pois, se o passado abrigaria o orgulho das tradições anhanguerinas, em contrapartida desse mesmo passado adviriam as negativadas imagens de decadência, de atraso e do vazio. O questionamento a uma memória estigmatizada assume um papel central na arena política e cultural de Goiás, mediante uma dupla operação permeada por intencionalidades: por um lado, recuperavam-se as sedimentadas representações que matizavam o estado para destacar a premência de mudanças; por outro, redefiniam-se os 
horizontes de expectativa por meio de um movimento reorientativo. No alvorecer da década de 1930, a modernidade emergiria como antítese de tudo aquilo que se faria crer que Goiás não pretendia mais ser e, diante da batalha de símbolos, se condensaria em torno de duas cidades - a antiga e a nova capital - a estruturação de antagonismos. Assim ressurgiria no estado uma pauta histórica: a transferência de sua sede administrativa.

\subsection{Do discurso ao traço}

Unicamente a presença do ouro em suas terras determinou a fundação de Vila Boa, pois essa vila, localizada [...] numa região estéril e afastada de todos os rios atualmente navegáveis, dificilmente estabelece comunicação com outras partes do império brasileiro. Não tem nem mesmo muita salubridade, e não tardaria a ser abandonada se nela não ficasse localizada a residência de todo o corpo administrativo da província. (SAINT-HILAIRE, 1848/1975, p. 50)

Em 1942, durante a sessão solene de inauguração de Goiânia nos festejos do Batismo Cultural, Pedro Ludovico Teixeira apresentaria em seu célebre discurso de abertura um olhar retrospectivo aos caminhos percorridos até aquele momento, em que se coroava a nova capital como uma realidade galgada. O interventor rememoraria que, ao assumir o governo estadual em novembro de 1930, a si delegaria o compromisso de evitar ao máximo incorrer nos erros das administrações pregressas - e que, dentre as muitas falhas que afirmaria ter encontrado após minuciosa revisão, se destacava especialmente a infortuna questão da permanência da sede administrativa na Cidade de Goiás. Na visão de Ludovico, faltara até então um administrador que se empenhasse verdadeiramente em solucionar a adversidade que há muito contribuía para a ruína de Goiás e que, diante do estado de apatia que encontrara, para rumar ao progresso lhe era inevitável lançar-se "firme e desassombradamente à concretização da ideia-força" (TEIXEIRA, 1973, p. 193).

A transferência da capital apresentava-se assim como uma iniciativa premente, e o interventor respaldaria sua asserção indicando que a Cidade de Goiás, que nunca antes ultrapassara os dez mil habitantes em mais de dois séculos de existência ${ }^{11}$, detinha uma população iminentemente decrescente, ao mesmo tempo que o número médio de residências erguidas entre 1914 e 1932 não superava a cifra de 1,5 por ano - remetendo a um cenário de estagnação. À semelhança de Goiás, se sua antiga capital homônima - antes denominada Arraial de Sant'Anna e Vila Boa - outrora prefiguraria a suposta pujança da mineração, tão logo se esboçasse o esgotamento da atividade igualmente passaria a simbolizar - sob os olhos de muitos e por um longo período - a própria decadência.

\footnotetext{
${ }^{11}$ Por outro lado, Savage-Landor (1913) menciona uma população de 13.475 habitantes na capital de Goiás, de acordo com um censo datado em 1900. No entanto, a veracidade da informação é questionável, de sorte que o viajante alertaria duvidar que ali houvesse de fato mais que 8 ou 10 mil pessoas.
} 
Todavia, conquanto só fosse efetivamente levada a cabo no século $\mathrm{XX}$, a ideia da mudança da sede administrativa de Goiás não era nova, tampouco teria sido necessariamente desprezada pelos governos passados. Conforme sinalizaria o próprio Ludovico, era remota a origem da questão, uma vez que as críticas à então capital habitavam numerosos relatórios oficiais. Num dos primeiros juízos acerca do tema, em meados do século XVIII, o governador Conde dos Arcos replicaria uma consulta do governo português se posicionando favoravelmente à transferência da capital de Vila Boa para o Arraial de Meia-Ponte (hoje Pirenópolis). No entanto, segundo Palacin e Moraes (1977/2008), o empreendimento se mostraria reiteradamente inviável tanto pelo grande montante orçamentário que demandava quanto pelo intenso movimento oposicionista dos vilaboenses - que, além de motivos de ordem afetiva, temiam prejuízos financeiros com a perda do título de capital.

Sem penetrar nas veredas por onde seguem tais debates ao longo dos séculos, em especial destaca-se aqui a ampla recuperação desses discursos para arrimar a necessidade de uma nova capital. Mais ainda: essa linha discursiva seria apropriada não apenas pelo poder político em si, mas similarmente se apresentaria absorvida por outros segmentos como a imprensa - conforme demonstra Arrais (2013) em Mobilidade discursiva: o periodismo político em Goiás - ou, ainda, pelos técnicos que atuariam de forma ativa na construção da cidade.

Armando Augusto de Godoy, por exemplo, mencionaria os governantes decimonônicos Miguel Lino de Morais e Couto Magalhães ao sintetizar a história da mudança da capital numa entrevista ao jornal carioca $A$ Manhã. Alinhando-se à narrativa de Ludovico, Godoy afirmaria que, a despeito da posterior retomada do problema por outros personagens, ninguém teria logrado qualquer resolução até a ascensão do interventor, dirigente que passou do sonho à ação, encarando o litígio com disposição para resolvê-lo apesar das fortes objeções (HISTÓRIA..., 1942).

Já Attilio Corrêa Lima, em seu resumo Goiânia - a nova capital de Goiás, iria além. O urbanista apontaria o "aspecto desolador de todo o interior brasileiro, onde a cada passo, encontramos vestígios de prosperidade em épocas passadas" (LIMA, A. C., 1937/1942, p. 83) e enfatizaria que, para desencadear transformações estruturais num meio que ainda conservava traços de uma economia feudal, a mudança da capital figuraria como principal medida a ser tomada. Attilio chegaria a transcrever juízos de antigos administradores da província, como Couto Magalhães, contribuindo para associar à antiga capital as imagens que Goiás visava superar. 
Temos decaído desde que a indústria do ouro desapareceu. Ora, a situação de Goiaz era bem escolhida quando a província era aurífera. Hoje, porém, que está demonstrado que a criação do gado e a agricultura, valem mais do que quanta mina de ouro há pela província, continuar a capital aqui é condenar-nos a morrer de inanição, assim como morreu a indústria que indicou a escolha deste lugar. As povoações do Brasil foram formadas a esmo; e economia política era uma ciência desconhecida, de modo que o governo ainda que quisesse não poderia dirigir com acerto essas escolhas: hoje porém assim não é. Uma população de 5.000 homens colocada em um lugar desfavorável, não pode nada mais produzir, do que o necessário para a sua nutrição. (MAGALHÃES, 1863 apud LIMA, A. C., 1937/1942, p. 85)

Noutro momento, ao reportar sobre o problema edílico na Cidade de Goiás, Corrêa Lima citaria Rodolfo Gustavo da Paixão, presidente do estado aos fins do século XIX. Diante da persistente falta de iluminação e da carência de salubridade, denunciava-se um quadro de abominação.

[...] espreguiçando-se às margens do rio Vermelho, mas curtindo uma verdadeira sede de Tântalo, visto como a água viscosa deste ribeiro, despejo e lavadouro da população, não é e nem pode ser convenientemente distribuída às casas, porque a fornecida pelo único chafariz existente e parcas fontes, carece de condições de abundância e potabilidade; desprovida de bom sistema de esgotos, capaz de evitar o uso prejudicialíssimo das latrinas perfuradas no terreno, onde as matérias fecais, sem escoamento entram em rápida decomposição e exalam deletérios miasmas, e absorvidas pelo subsolo, bastante permeável, comunicam-se com os poços de serventia, de ordinário abertos nas proximidades daqueles focos de infecção, a decadente Vila Boa, hospeda em seu seio poderosos agentes de destruição, que hão de em breve, transformá-la em vasta necrópole, onde a morte campeie com todo seu cortejo de horrores. (PAIXÃO, 1890 apud LIMA, A. C., 1937/1942, p. 91)

Além do empenho em resgatar a genealogia da ideia de deslocar a capital, constantemente empregando relatos de ex-governantes, chamaria atenção outro aspecto quase despretensioso deste mesmo texto, que aparece especificamente em sua versão publicada em 1937 na revista Arquitetura e Urbanismo: um desenho parcial da Cidade de Goiás, feito em bico de pena pelo próprio Attilio (ACKEL, 2007). Originalmente acompanhado da inscrição "RUA DESERTA - Um aspecto da velha Capital", o croqui retrataria uma via urbana aparentemente a antiga Rua dos Mercadores, atual Rua Dom Cândido, a partir do Largo do Rosário -, de traçado quase retilíneo e com modestas construções de feições coloniais adossadas entre si, dispostas lindeiramente à rua e todas de pavimento único, embora seja possível ver pelo menos uma “casa de porão alto". Com exceção de um vulto masculino em primeiro plano, reforça-se a inexistência de qualquer outra movimentação no espaço público. A legenda sugere se tratar de uma característica habitual da bicentenária cidade. 


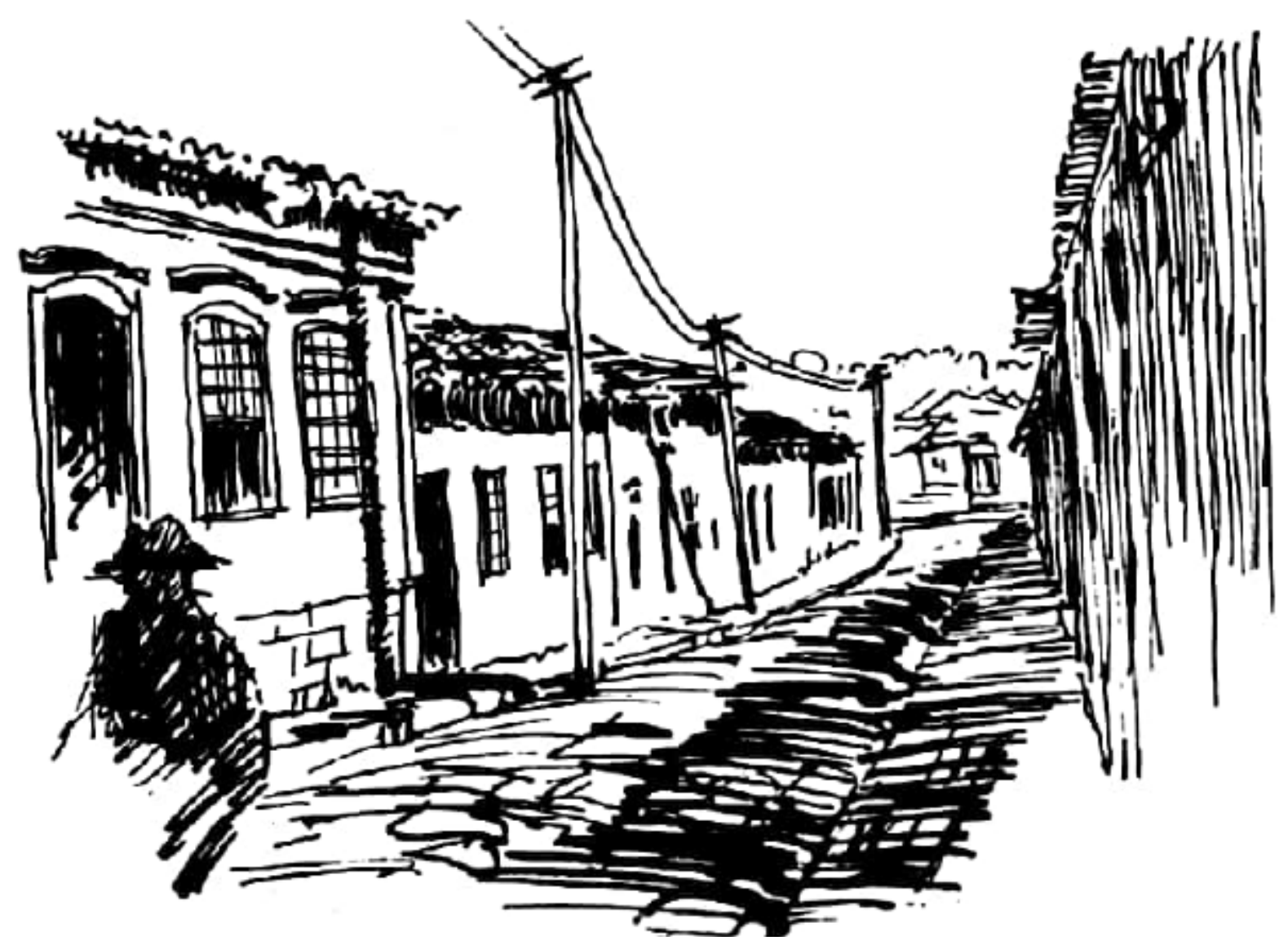

Figura 1: A Cidade de Goiás num croqui de Attilio Corrêa Lima. Fonte: Arquitetura e Urbanismo (1937).

Sem supor qualquer contato intencional, não deixa de ser interessante estabelecer paralelos entre o croqui de Attilio - bem como os juízos por ele evocados - e outras representações iconográficas da Cidade de Goiás, anteriormente registradas por alguns viajantes europeus. No início do século XX, por exemplo, Savage-Landor (1913) estamparia sua obra com uma fotografia tomada por ele próprio a partir da porção baixa da Praça Brasil Ramos Caiado (antiga Praça do Paceyo Publico) [sic], nas imediações do Quartel do XX Batalhão de Infantaria. É curioso notar como o registro deste importante espaço livre da capital, amplo e rodeado por edifícios públicos, ao invés de evidenciar figuras humanas ou sinais de uma enérgica dinâmica urbana, remeteria na verdade a um lugar bucólico e praticamente deserto - se não fosse a presença de parcos animais. Ao mesmo tempo, SavageLandor (1913) já sinalizaria tecer impressão similar logo após sua chegada à capital, ao indicar que toda a população da cidade aparentava estar escondida, fitando-o timidamente através de janelas semicerradas - e os poucos habitantes que ele encontrara nas ruas pareciam querer saudá-lo, mas não tinham coragem para tal. Segundo o viajante, "a imagem de um estranho em Goyaz era aparentemente um evento" (SAVAGE-LANDOR, 1913, p. 89). 


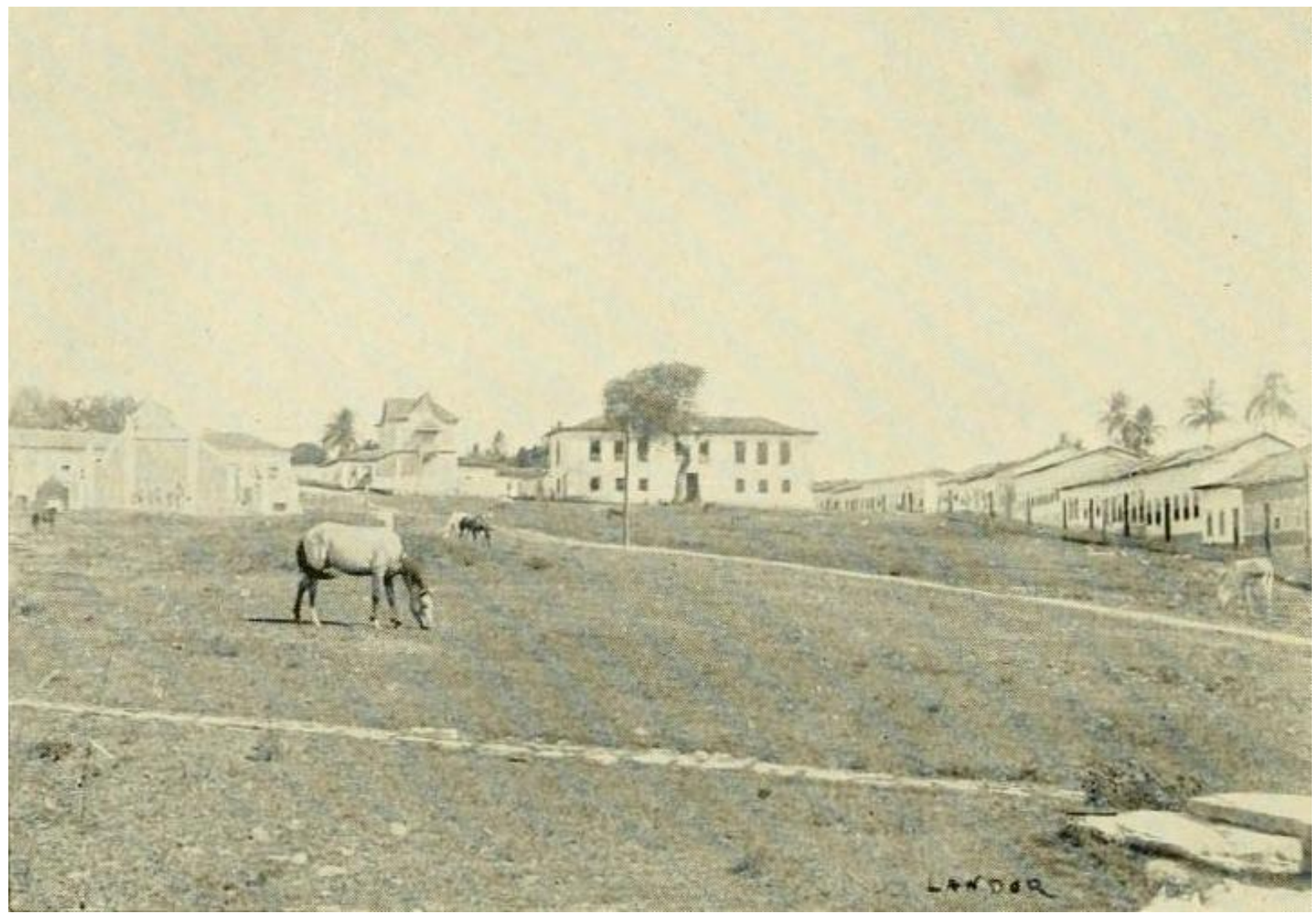

Figura 2: “A praça principal da Cidade de Goiás. Mostrando a prisão e a biblioteca pública". Legenda da publicação. Autoria: A. Henry Savage-Landor. Fonte: Savage-Landor (1913).

Em contrapartida, uma gravura presente na obra de Pohl (1832/1951, p. 24) sugeriria uma perspectiva distinta, tanto em termos literais - a partir do registro pouco comum da entrada sul da cidade - quanto metaforicamente - uma vez que a imagem enfatiza o "aprazível encanto" que se esquadrinharia diante daqueles que chegavam à capital, revelando seu caráter pitoresco. A vista, tomada no início do século XIX por Pohl através de uma câmera lúcida ${ }^{12}$, desenhada por Thomas Ender e gravada em cobre por Johann Axmann, possui características que lembram obras de pintores como Debret e Rugendas: a exuberante vegetação local compartilha o primeiro plano com alguns indivíduos, dentre eles trabalhadores de fazendas e engenhos locais e um tropeiro de São Paulo, além de elementos como o perene carro de boi. A Cidade de Goiás se descortina ao fundo, com suas casas, edifícios públicos e numerosas construções religiosas, como a Igreja de Nossa Senhora do Rosário e a capela de Santa Bárbara, no topo de uma colina. Não deixa de ser paradoxal o fato que essa representação, nos limites da cidade, apresente mais figuras humanas que muitas outras registradas em pleno centro urbano. Ademais, ao apreender a gravura, não se poderia

\footnotetext{
${ }^{12}$ Concebida no início do século XIX, a câmera lúcida consiste num aparato óptico capaz de projetar sobre uma superfície de desenho determinada paisagem ou objeto disposto em frente ao observador, de modo a assistir processos de ilustração.
} 
necessariamente pressupor a existência de sinais de decadência, tão reiterados em descrições. Pohl (1832/1951, p. 326), entretanto, advertiria o leitor: “embora, ao viajante, depois de ter atravessado por dias inteiros vastas planícies e campos crestados, a primeira vista da cidade ofereça um belo quadro, o interior não corresponde ao exterior, sendo a vista pouco atraente".

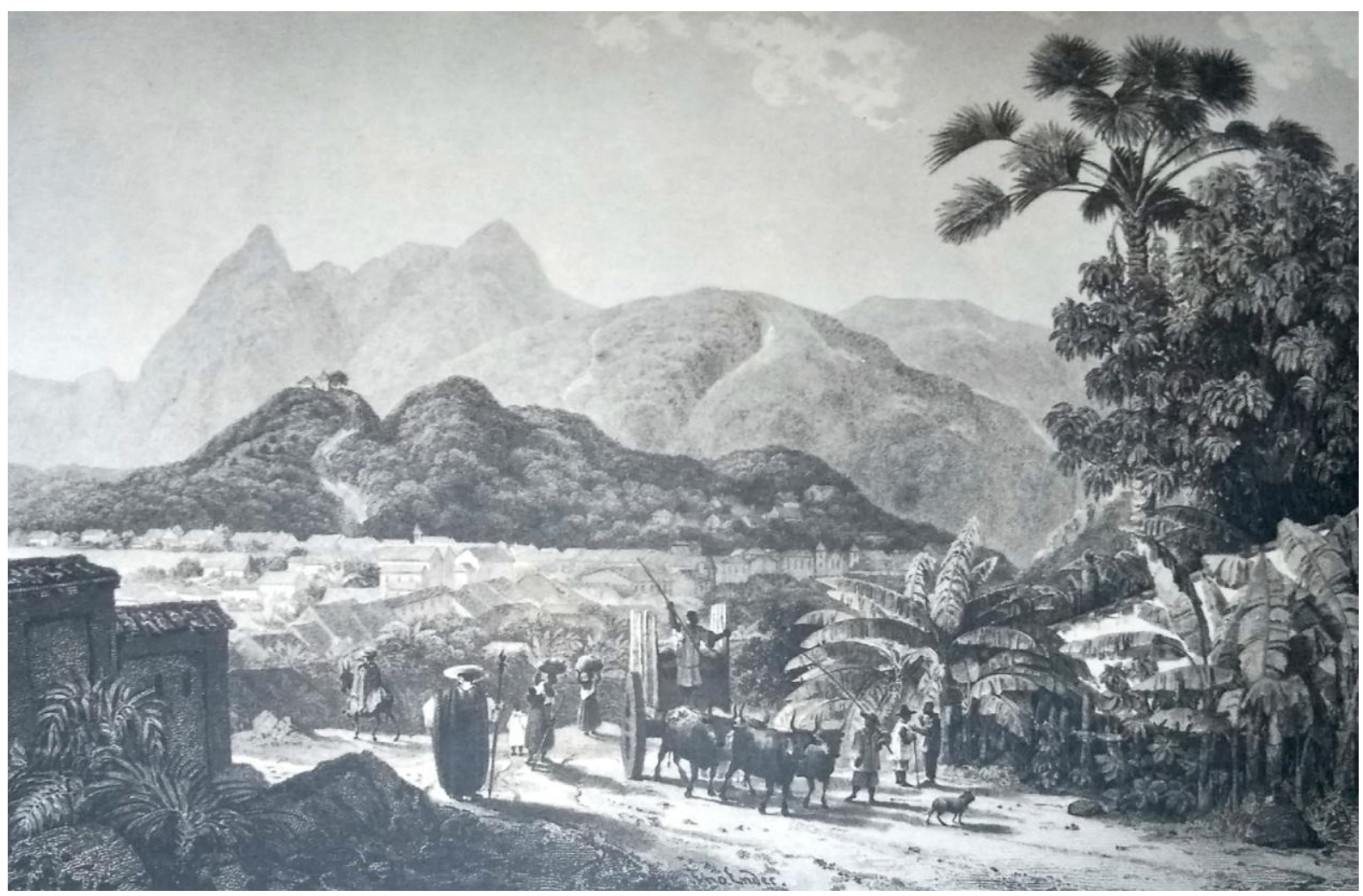

Figura 3: "Goiás, antiga Vila Boa, capital da capitania de Goiás". Legenda da publicação. Autoria: Johann Pohl; Thomas Ender; Johann Axmann. Fonte: Pohl (1832/1975).

Outro aspecto da imagem que também merece destaque é o relevo, de traço acidentado. Contudo, se na ilustração as serras erguem-se como um importante elemento visual, conferindo à então capital uma paisagem de aparência pitoresca - bastante acentuada pelo desenho de Ender, diga-se de passagem, visto que as cristas dos morros são representadas de modo mais proeminente do que de fato são -, nos relatos a situação topográfica da Cidade de Goiás é tomada como responsável por lhe agravar o persistente problema da salubridade. Nesse sentido, consonantemente a abundantes juízos, Saint-Hilaire sentenciaria:

A cidade, construída numa baixada, onde o ar não circula como nas montanhas e nas planícies; onde a água parece pouco salubre e o calor é quase sempre sufocante durante a seca; onde, enfim, a umidade deve ser muito grande na estação das chuvas [...]. Essa é uma razão por que os habitantes de Vila Boa estão longe de apresentar uma aparência de saúde, vigor e energia. (SAINT-HILAIRE, 1848/1975, p. 51)

Pavimentando o caminho dos antagonismos, em meio à construção de discursos para preterir Goiás como sede administrativa do poder estadual, recupera-se na década de 1930 a 
linha de argumentos concernente às insatisfatórias condições de salubridade e implantação da cidade, de sorte que essa passa a assumir uma relevante posição no debate. Sob um viés tecnicista, Armando de Godoy, que anteriormente defendera a importância vital da cidade moderna ${ }^{13}$ como fator de progresso, se debruçaria sobre os problemas dessa ordem.

\begin{abstract}
A sua velha capital se acha localizada pessimamente, sendo uma prova disso as suas lamentáveis condições urbanas, não podendo desempenhar as múltiplas funções que cabem a uma capital. [...] As condições topográficas, geológicas e climatéricas lhe são contrárias. Ela evoluiu como, em geral, todas as vilas que surgiram em terreno acidentado, na maior desordem, contrariando sobremodo as tendências modernas. Não é possível solucionar-se economicamente o problema de sua remodelação, tais as dificuldades que apresentam o traçado atual, a superfície dos terrenos e o seu subsolo. Sob o ponto de vista arquitetônico e do saneamento, os obstáculos são inúmeros. Melhor será conservá-la como se acha, e respeitá-la na sua formação colonial, repetindo-se em relação a ela o que Minas fez com Ouro Preto. (GODOY, 1934/1942, p. 36-37)
\end{abstract}

Apontando mesma lógica, Pedro Ludovico Teixeira dedicaria expressivo trecho em seu relatório sobre a mudança da capital, apresentado ao chefe do então Governo Provisório Getúlio Vargas, para abordar o tema. No documento, o interventor denunciaria o calamitoso estado de saneamento e habitabilidade da antiga Vila Boa, cidade que permaneceria como um “ajuntamento desordenado de casas anti-higiênicas e antiestéticas, apertando-se violentamente uma as outras, dentro de estreitíssima área acidentada, em torno da qual, comprimindo-a, asfixiando-a quase, se erguem morros e serras de todos os lados" (TEIXEIRA, 1933 apud MONTEIRO, O. S. N., 1938, p. 6).

Muito desse tom de Ludovico se arrima na pressuposta objetividade do saber científico, tão caro sobretudo frente aos embates entre mudancistas e antimudancistas que se sucederiam ao longo do processo de transferência da capital - visto que a questão técnica, como esclarece Fernandes (2012), fortalece-se principalmente no pós-1930 mediante uma dupla promessa: por um lado, atuaria como elemento legitimador, à medida que sua suposta neutralidade se disporia alheia às disputas pessoais, políticas ou ideológicas; por outro, seria

\footnotetext{
${ }^{13}$ Anos antes de associar o ínfimo desenvolvimento das potencialidades de Goiás à inexistência de um centro moderno, Godoy (1926/1943, p. 32) indicaria a necessidade dos estudos dos fenômenos urbanos - o urbanismo como meio de alcançar um tipo de organismo urbano - a cidade moderna -, "para o qual se deve tender, afim de que melhor se satisfaçam as necessidades das grandes agremiações humanas". No entanto, só se poderia conceitua-la desse modo se a urbe detivesse "um regular abastecimento de boa água; uma rede de esgotos com a capacidade e as condições necessárias para dar escoamento a todas as águas poluídas; um serviço organizado para a remoção imediata de todas as imundícies; uma rede de cabos e fios elétricos para uma boa distribuição de luz e de energia por toda a parte; uma rede telefônica que inclua todos os bairros; um serviço de transportes rápidos, através de um sistema de vias que permita comunicações fáceis entre as diferentes zonas. um número regular de praças, jardins, parques e campos de recreio, que estejam situados a distâncias convenientes. casas com conforto moderno para a população pobre, todas as quadras com áreas espaçosas e pátios que permitam a respectiva ventilação, etc." (GODOY, 1926/1943, p. 32-33). Diante dos requisitos da cidade moderna, o engenheiro-urbanista concluiria que as capitais brasileiras estariam distantes de serem caracterizadas como tal.
} 
um caminho para organizar, pelo menos parcialmente, a nova estrutura do Estado, através de conselhos técnicos e comissões.

É nessa mesma esteira que a ciência urbana, em plena formação como campo de reflexão e ação no Brasil, galga um privilegiado espaço no plano do interesse público do país e igualmente na arena política de Goiás de modo que, como já pôde ser visto até aqui, não seria rara a utilização de dados, estudos e argumentos técnicos para embasar cada passo rumo ao deslocamento da sede administrativa, em geral amparado por especialistas - dentre eles, Armando de Godoy e Attilio Corrêa Lima, cujo prestígio em princípio limitaria a possibilidade de questionamentos, mas também outros agentes num processo conduzido por muitas mãos. Em meados de 1932, por exemplo, o prefeito Mário da Costa Ferreira (apud CHAUL, 1988), aspirando tornar Bonfim a nova capital do estado, citaria um memorial elaborado pelo engenheiro Carlos Haas - apontado como o primeiro estudo técnico acerca da transferência da capital goiana, datado em 1931 (MENDONÇA, J. G. C., 2013) - para alegar ao interventor que sua cidade ofereceria as melhores condições de acordo com as exigências do urbanismo moderno. Já nos fins de 1932, quando se havia tomado a decisão de erguer uma nova cidade, Pedro Ludovico responderia uma indagação sobre a escolha da localidade arrimando-se, mais uma vez, na técnica.

\footnotetext{
Ainda não temos resolvido o local em que será construída a nova capital. Antes de mais nada, será nomeada uma comissão, composta de médicos, comerciantes, engenheiros, etc. para escolher o lugar mais apropriado. No Estado há quem opine pela construção nas terras do município de Campinas, onde todos os fatores são favoráveis, inclusive o de transporte, dada a proximidade da Estrada de Ferro de Goiaz. Há também as planícies do rio Urú, distante 12 léguas da atual capital. Isto, porém, constitui um problema que somente a comissão a ser nomeada resolverá. (TEIXEIRA, 1932 apud MONTEIRO, O. S. N., 1938, p. 29-30)
}

Outrossim, convém reparar que à própria figura do interventor concomitantemente se incorporariam os signos da cientificidade. Pois, formado em medicina no Rio de Janeiro num momento em que o higienismo regia as severas intervenções urbanísticas na então capital federal -, Pedro Ludovico se valeria do saber médico para sazonar uma retórica validada por sua tecnicidade, apresentando-se como personagem particularmente capaz de examinar, diagnosticar e medicar os problemas de Goiás - ainda que, ironicamente, pelo menos um de seus predecessores dos tempos das oligarquias também tivesse a mesma formação. A partir desta perspectiva, se Chaul (1997/2010) sintetizaria que à capital se conferiria a imagem de um doente em estado terminal, caberia ao médico - que se tornou político - achar um remédio para que o estado pudesse ser curado do abatimento. Nas palavras de Ludovico:

Eu tinha de quebrar a rotina e a apatia dos governos passados. Estudando detida e intensamente o problema, refleti se não seria conveniente transferir a sede da 
administração para alguma cidade do interior goiano, transformando-a em capital, ainda que tivesse de dar-lhe nova fisionomia, urbanizando-a segundo os mais modernos preceitos. O conhecimento profundo que eu possuía dos aglomerados humanos de minha terra fez-me abandonar por errada essa solução, como errado seria tentar o melhoramento da velha Goiaz. [...] Estudei o problema sob todos os seus aspectos e tomei uma deliberação: ou cumpriria a missão que me tinha imposto ou voltaria, com prazer, à minha vida de médico nos sertões goianos, nas belas regiões sudoestinas da minha dadivosa terra. ("PORQUE..., 1942, p. 7)

Gradativamente passaria a se afirmar que a nova capital, símbolo de um novo tempo, deveria ser uma cidade construída especificamente para tal finalidade. Seria uma obra filha de uma época distinta, regida pela técnica, pelo planejamento e pelo cálculo pensante, enquanto a antiga capital, caduca, seria fruto da aventura, do acaso e do esmismo colonial (FONSCECA, 1943), pressupondo a inexistência de qualquer desígnio - o que se refuta pois, respeitadas as especificidades de seu tempo, é possível verificar diferentes formas de disciplina urbanística nos núcleos urbanos estabelecidos em regiões de mineração (REIS FILHO, 1999) ${ }^{14}$.

Goiânia, a capital de Goiaz, recentemente construída, é, por enquanto, e o será ainda
por muito tempo, a cidade modelo do país. Surgiu numa época em que o urbanismo
passou a ser sistematização de princípios científicos a serviço da arte de construção
ou remodelamento de cidades. [...] Remodelar, porém, é fazer o possível para criar,
no que já existe, novos aspectos sob o ponto de vista da beleza panorâmica, como,
também, sob o do bem estar dos habitantes das cidades, o que se consegue apenas
parcialmente, tantos são os óbices que surgem em relação ao necessário respeito ao
que já está feito, avultando, além dos de ordem técnica, os econômicos. Não quer
isso dizer que não se pode ou não se deve remodelar, ao contrário. A história das
cidades brasileiras exige esse conserto: foram construídas, as mais antigas, sem
atenção ao local que seria qualquer desde que houvesse água e não ficasse longe das
fontes de mineração mais rica. [...] essa [Goiânia] surgiu da terra virgem, entre o
campo e a mata. Toda previsão técnica possível, nesta altura da grande evolução
urbanística, foi aproveitada nos planos que ora se vão ali executando [...] Foi, por
esses cuidados técnicos, que constituíram o ponto de vista permanente do interventor
Pedro Ludovico, que Goiânia pode chegar a merecer o nome de cidade modelar. E lá
está, em pleno sertão, aquela prova de que os valores humanos são capazes de criar o
progresso. (O CASO..., 1941, p. 8)

Ressalta-se, entretanto, que o engendramento dessas narrativas (e do jogo dicotômico) se assenta em intencionalidades que, por sua vez, também conduzem práticas que nem sempre são condizentes com o que é enunciado. Dessa maneira, não surpreende que o próprio Pedro Ludovico Teixeira (1973) tenha revelado algumas vezes, inclusive no discurso da inauguração oficial de Goiânia, que não teriam sido necessariamente os motivos de ordem sanitária que o fizeram retirar da Cidade de Goiás o título de sede administrativa talvez esboçando um tom conciliatório que se verificaria à medida que Goiânia se concretizava -, mas sim motivações de caráter político, econômico e social que há muito

\footnotetext{
${ }^{14}$ Reis Filho (1999, p. 24) mencionaria Goiás em seu trabalho, indicando que as diretrizes urbanísticas da antiga capital demonstravam "preocupação com padrões de regularidade mais formais" ao determinar que as ruas fossem traçadas com linhas retas e que as casas tivessem o mesmo perfil de fachada. No entanto, verificou-se o não cumprimento das instruções, "o que indica uma discrepância entre os objetivos da administração colonial e os padrões adotados pelas administrações municipais" (REIS FILHO, 1999, p. 27).
} 
habitavam o subconsciente dos goianos. Ou ainda não gere espanto o fato de que, a despeito do rigor e da neutralidade técnica, mesmo anteriormente à nomeação da comissão para estudar os possíveis locais da nova capital, já haveria uma predefinição em favor do mencionado sítio nos arredores da pequena cidade de Campinas - de acordo com as argumentações de Arrais (2013) - e até mesmo a ocorrência de uma visita de Corrêa Lima ao local em 1932, por convite de Pedro Ludovico, como sinalizaria o próprio urbanista (GOIÂNIA..., 1942) - e conforme esquadrinharia Diniz (2007), após ter acesso ao relatório original de Attilio.

Assim, se a escolha da área em princípio obedeceria a critérios objetivos como facilidade de acesso e transporte e boas condições topográficas, hidrológicas e climatológicas, segundo registrado em atas e pareceres, não se pode perder de vista que a transferência da capital é fortemente motivada por anseios políticos. A mudança metaforizaria a transferência de poder que ocorre após a Revolução de 30, demovendo o eixo político de um locus associado à apatia governamental (e às oligarquias) para uma região que se fixava como eixo econômico e demográfico de Goiás - sem esboçar qualquer intento de unificar um território heterogêneo, o que acentuaria "ainda mais o caráter já excêntrico da chefia do Estado", nos termos de Bruand (1973/2016, p. 349).

De qualquer modo, a localidade de Campinas seria oficialmente aprovada pela comissão em março de 1933, a partir de um parecer da subcomissão técnica. Na sequência, antes de um veredito definitivo, Pedro Ludovico ainda acataria a sugestão do presidente da comissão, o bispo dom Emanuel Gomes de Oliveira, e faria uma nova consulta para respaldar o arbítrio. É nesse momento que Armando Augusto de Godoy, expoente numa espécie de "militância intelectual" que se forma para divulgar a relevância do urbanismo para os destinos do país (RIBEIRO, L., 2015), é convidado para avaliar - e substancializar - a decisão, fornecendo seu primeiro aporte rumo à concretização da nova capital de Goiás.

As credenciais de Godoy para emitir o juízo seriam incontestáveis. Graduado pela Escola Politécnica do Distrito Federal, professor do Colégio Militar do Rio de Janeiro, redator-chefe da Revista Municipal de Engenharia e membro da diretoria do Automóvel Club do Brasil, o engenheiro precedentemente ainda atuara de modo decisivo para viabilizar a elaboração do famoso Plano de Remodelação, Extensão e Embelezamento do Rio de Janeiro, atribuído ao francês Donat-Alfred Agache - nome que, diga-se de passagem, fora sugestão de Godoy. Não por acaso, sua notoriedade seria constantemente ressaltada ao longo de sua participação no processo de construção de Goiânia, como se vê numa edição do Correio Oficial. 
Desempenha o dr. Armando de Godoi cargos técnicos da maior responsabilidade, quer em repartições federais, quer na prefeitura do Distrito Federal, onde foi o maior colaborador do sr. Alfred Agache, urbanista francês encarregado pelo Prefeito Prado Junior do plano-diretor do Rio de Janeiro. [...] percorre recentemente em viagem de estudos urbanísticos e mantem-se (o dr. Godoi) em contato permanente com os principais centros americanos, país em que o Urbanismo é hoje lei federal. Possui uma bibliografia completa, em que estão estampadas todas as realizações intentadas nos últimos anos, com o enorme desenvolvimento do urbanismo. (CORREIO OFICIAL, 1936 apud ALVARES, 1942, p. 15-16)

Armando Augusto de Godoy, após visitar a área, encaminharia ao interventor um documento registrando sua posição acerca da mudança da sede administrativa para as imediações de Campinas. Segundo o técnico, as condições do local escolhido seriam favoráveis, uma vez que ali se encontrariam indiscutivelmente "os principais requisitos para comportar a fundação de um moderno centro de população" (GODOY, 1933/1943, p. 222) não apenas em termos físicos - algo que, para Godoy, seria uma fácil tarefa diante do que vira no estado -, mas também pela proximidade da estrada de ferro e pela posição de centralidade numa zona que, por ele, seria considerada a mais próspera de Goiás.

Sem embargo, chama atenção que Godoy, em seu relatório de 1933, não se limitaria a analisar o sítio ou levantar elementos de ordem imediata. À semelhança de outras ocasiões, o profissional demonstraria uma preocupação didática ao expor a relevância da cidade moderna - onde ocorreria "a coordenação dos movimentos e das atividades de uma nação" (GODOY, 1933/1943, p. 212) - e se deter em preceitos necessários para viabilizar seu pleno estabelecimento, antecipando recomendações para a futura capital. Deste modo, amparado em numerosos exemplos (de Belo Horizonte a Letchworth, de Radburn a Magnitogorsk), Godoy exploraria aspectos de caráter financeiro - como o financiamento das obras e incentivos fiscais -, infraestrutural - como energia elétrica e ligações rodoviárias - e até mencionaria questões como a integração regional e o destino dos arrabaldes da cidade, revelando em seu texto o sentido holístico contido no campo de atuação da ciência urbana.

Posteriormente, será possível observar que determinados pontos indicados por Armando Augusto de Godoy particularmente se manifestariam não apenas na cidade-ideia, mas também na cidade-obra e cidade-concretude. Voltaremos ao relatório, portanto, ao longo da dissertação. Por ora, interessa-nos assinalar que, além de seu papel legitimador, o urbanismo igualmente despontaria como meio de alcançar uma cidade verdadeiramente moderna, cristalizando-se discursivamente como uma faceta da modernidade que se associaria ao Goiás pós-1930 - modernidade essa que, aliás, não se encerraria nos limites da nova capital, mas através dela irradiaria para todos os seus rincões. Como sinalizaria Pedro Ludovico: 
A construção de Goiânia está se realizando com observância dos mais modernos preceitos do urbanismo e higiene. De modo que representará ela ponto seguro onde os habitantes de outras cidades irão colher observações necessárias para melhorar as suas condições de vida, no tocante à importante questão da habitação. [...] A nova sede do governo dispõe de todos os elementos para ser o centro irradiador do progresso de todo o Estado. O tempo demonstrá-lo-á. (GOIÁS..., 1935, p. 5)

Attilio Corrêa Lima (1937/1942), noutro momento, apontaria sentido similar. De acordo com o urbanista, num estado de assentamentos pouco populosos, a criação de um centro com os completos requisitos das modernas cidades habilitaria o desenvolvimento de toda a região em progressão geométrica. Ao mesmo tempo, como centro administrativo, o caráter de Goiânia seria exemplar.

Sua posição deverá ser sempre na vanguarda, como tipo modelar, a sua estrutura urbana deve ser ampla, refletindo uma certa nobreza de linhas, quer no seu traçado, quer na sua edificação. [...] O rigor das medidas nela aplicadas será exemplo que despertará as outras aglomerações urbanas do seu letargo. Goiânia não vale somente pelo seu valor intrínseco, mas principalmente pela influência que poderá exercer. Num país ou num Estado, a capital é sempre o padrão, onde os outros satélites se espelham, por isso designavam-na os antigos de "Metrópole". (LIMA, A. C., 1937/1942, p. 96-97)

Em contraponto aos estigmas que se avocavam a Goiás - cidade e estado -, a construção ex nihilo de uma capital representaria assim a pedra angular de uma ampla transformação. E diante da privilegiada e ambígua relação que se estabelece entre o urbanismo e o Estado, sobretudo ao compartilharem um perfil reformador, Goiânia se inscreve numa lógica em que paulatinamente passaria a se acreditar que uma distinta ordem espacial seria caminho e resultado de uma distinta ordem social, conforme apontaria Topalov (1991). Sob esta perspectiva, ainda segundo o autor, a cidade nova potencialmente compreenderia mais que a racionalização do espaço: ao alterar radicalmente o conjunto de atividades cotidianas, seu empreendimento permitiria "reorganizar não somente os hábitos individuais, mas também a vida coletiva das classes populares” (TOPALOV, 1991, p. 33).

Naturalmente, esses discursos imantados por rupturas demandam um olhar cauteloso, uma vez que muitas dos nexos pregressos permaneceriam multiformemente ativos na nova capital. Contudo, não se deixa de notar certo grau de absorção destas ideias, de sorte que se afirmaria que Goiânia seria capaz de oferecer aos goianos "um ambiente próprio ao maior desenvolvimento de sua cultura" (SENSACIONAL..., 1936, p. 1) e, por sua suposta falta de história, se veria na nova capital uma civilização própria - sem a existência de fortes tradições de família ou de indivíduos que se julgassem donos da cidade ou do governo. Ou semelhantemente, Rosarita Fleury, um importante nome da literatura goiana, relembraria o sentimento de mentalidades distintas a partir da nova capital. 
Nossa alegria era muito grande nessa viagem, marco inicial da mudança da capital e que, com o correr do tempo, tornou-se marco inicial da mudança de estrutura de todo povo goiano. Uso e costumes seriam alterados e nós, goianos, em nossa maneira de ser, iniciávamos, naquele dia [do lançamento da pedra fundamental], a caminhada para uma sociedade mais aberta, com menores preconceitos e maiores liberdades na maneira de ser, de proceder e também maior independência de pensamento. Porque, como se acompanhando a topografia local, enquanto na bela Goiás cercada de morros, pensamentos, ideias e ideais, a princípio se fechavam em concha, para desabrocharem amadurecidos na elegância e nobreza das tradições vigentes, nos descampados que aqui se abriam, uma constante mutação de pensamentos favorecia e incitava a que se procurasse a descoberta de novos valores. (FLEURY apud GOIÂNIA, 1985, p. 161)

Em suma, cercando-se de elementos que pudessem distingui-la de práticas e representações anteriores, Goiânia é idealizada como representação de modernidade, antes mesmo que qualquer traço de materialidade. Ou seja: a representação precede a cidade - ao mesmo tempo que é continuamente atualizada no decorrer do processo - e orienta sua concepção física e discursiva. Assim, conquanto não seja necessariamente um consenso ${ }^{15}$, aqui parece tornar-se evidente, pelos menos retoricamente, a afirmativa de Gorelik (1999, p. 59) que disporia que a modernidade - tomada por ele como ethos cultural, numa acepção distinta de Berman (1982/1986) - antecederia a modernização - "um complexo de estruturas e processos materiais" (BERMAN, 1982/1986, p. 128). Em outros termos, a modernidade se articularia como meio para se alcançar a modernização, não seu corolário, mediante a "vontade ideológica de uma cultura para produzir um determinado tipo de transformação estrutural” (GORELIK, 1999, p. 59) - o que não pressupõe afirmar que inexistissem sinais de modernização em Goiás antes da década de 1930, como já pôde ser visto, mas que aparentemente se substancializariam através da aura de modernidade construída sobretudo através de Goiânia.

Como naturalmente o discurso não se encerra em si, ainda era necessário que as feições da nova capital fossem capazes de traduzir materialmente o novo tempo que se enunciava. Deste modo, com o favorável parecer de Armando Augusto de Godoy - a quem Pedro Ludovico afirmaria muito dever pelo encorajamento que forneceu à realização de sua empreitada (TEIXEIRA, 1973) -, o interventor igualmente se deteria na escolha de um expressivo nome a ser encarregado do desenvolvimento do plano de Goiânia. De acordo com algumas autoras, como Manso (2001), Cordeiro e N. Queiroz (1990), o primeiro profissional considerado pelo interventor teria sido Alfred Agache, naquela ocasião muito prestigiado em

\footnotetext{
${ }^{15}$ Campos (2000/2002) partiria do princípio quase inverso. Para o autor, apesar da vontade modernizadora conseguir se impor diversas vezes sobre condicionantes específicas, a problemática da modernização se relacionaria antes de tudo com o atraso - de maneira que o processo modernizador, imerso em paradoxos, sempre aconteceria parcialmente. Assim, no quadro de uma modernização periférica, estaríamos fadados a perseguir o moderno sem nunca atingir a modernidade.
} 
âmbito nacional por conta de sua atuação no Rio de Janeiro. Todavia, a ideia seria descartada, especialmente diante da celeridade exigida pelo momento. Conforme sugestão de um membro da comissão, restariam ainda dois nomes à altura da tarefa: Armando Augusto de Godoy e Attilio Corrêa Lima. Em meio a circunstâncias imprecisas ${ }^{16}$, o profissional escolhido seria Attilio. Indicado pela historiografia como o primeiro doutor em urbanismo do Brasil e tendo atuado diretamente no Plano de Remodelação, Extensão e Embelezamento do Rio de Janeiro enquanto trabalhava no ateliê de Agache em Paris (DINIZ, 2017), o urbanista deteria um currículo inquestionável - como sugere um periódico já em 1942, às vésperas do Batismo Cultural de Goiânia.

Attilio Correia Lima é um dos nossos mais brilhantes e arrojados urbanistas. Arquiteto pela Escola Nacional de Belas Artes, obteve, em 1926, o prêmio de viagem, e em 1930 regressava ao Brasil, depois de um curso destacado no Instituto de Urbanismo da Universidade de Paris. São de sua autoria os planos de remodelação de Niterói e Recife, e o plano da edificação de Goiânia. São projetos seus, também, os da transformação do Vale do Paraíba, no trecho que interessa à grande siderurgia e inclui obras de vulto nas cidades de Barra Mansa e Volta Redonda e na Vila de Pinheiro. (GOIÂNIA..., 1942, p. 1-3)

Também mencionado no discurso de Pedro Ludovico Teixeira (1973, p. 196), sobre Attilio o interventor diria que, ao longo do decurso à frente das atividades da nova capital, o urbanista se mostraria "um conhecedor profundo da sua especialização, revelando-se um perfeito técnico na tarefa de que se incumbiu". O processo de idealização material da cidade, porém, não adviria de um traço esboçado solitariamente. Pelo contrário: o plano seria obra de Attilio Corrêa Lima, assim como de Armando Augusto de Godoy, da Firma Coimbra Bueno (dos goianos Jerônimo e Aberlado) e de muitos outros agentes, conhecidos e anônimos, que participariam direta ou indiretamente de sua concepção. Sem o intento de estabelecer um olhar pormenorizado sobre o plano e suas interlocuções, já reiteradamente analisado por outros estudiosos ${ }^{17}$, desnovelaremos alguns fios dessa trama para compreender determinadas lógicas sob as quais se delineia (e se lê) a cidade-ideia.

\footnotetext{
${ }^{16}$ Posteriormente, numa conferência em Juiz de Fora, Godoy (1935/1943, p. 301) afirmaria que "foi por me negar a dar em curto espaço de tempo a primeira parte do plano de uma nova cidade do Brasil, que me não foi confiada a elaboração do mencionado plano". Trata-se de uma declaração vaga, mas que corrobora a hipótese de que Armando Augusto de Godoy chegou a ser sondado para conceber o plano de Goiânia. Ackel (2007) também aponta sentido similar, ao recuperar uma palestra onde Godoy sugeriria ter sido o primeiro convidado pelo interventor - mas que declinara por conta dos muitos compromissos que tinha.

${ }^{17}$ Internacionalmente, dentre as primeiras obras, pode-se citar menções em Brazil Builds, de Goodwin (1943), Cities of Latin America: housing and planning to the South, de Violich (1944) e Arquitetura Contemporânea no Brasil, de Bruand (1973/2016). Andrade (2005) recuperaria ainda outros autores, como Werner Hegemann (numa obra publicada em 1936) e Pierre Lavedan (na edição de 1952 da obra Histoire de l'urbanisme). Localmente, os primeiros títulos acerca do tema são as já citadas publicações pioneiras, contemporâneas à construção da cidade. Nestas, entretanto, a história da cidade tendia a ser tributária da história política, apresentando o urbanismo de forma utilitarista e sem adentrar numa leitura crítica. Essa lacuna, apontada por
} 


\subsection{As feições idealizadas para a nova capital}

Seria preciso uma tábua rasa para fundar o gigantesco empreendimento que se sonhava. Foi encontrada a cem quilômetros para leste, sob a forma dum planalto coberto somente de capim duro e de espinheiras, como se tivesse sido atingido por um flagelo destruidor de toda a fauna e inimigo da vegetação. [...] Como nenhum acidente natural existisse para importunar os arquitetos, estes últimos puderam trabalhar sobre o terreno como se o fizessem em suas pranchetas. O traçado da cidade foi desenhado na terra; delimitou-se o contorno e, no interior, as diferentes zonas: residencial, administrativa, comercial, industrial e a que se consagrou às distrações. (LÉVI-STRAUSS, 1955/1957, p. 127)

Poucos meses antes do lançamento da pedra fundamental de Goiânia, em 1933, Attilio Corrêa Lima seria oficialmente designado para elaboração do plano diretor da nova capital de Goiás. De acordo com o escopo firmado em contrato, o projeto deveria considerar um núcleo inicialmente previsto para 15.000 habitantes, com expectativa de posteriormente abrigar uma população, em princípio, de até 50.000 pessoas - naquele momento, um número quase pretencioso, visto que seria mais que o quíntuplo da população da então capital Cidade de Goiás e superaria até Catalão, município que na década de 1920 era o mais populoso do estado com cerca de 35 mil habitantes ${ }^{18}$ (PALACIN; MORAES, 1977/2008). O plano compreenderia sistema de logradouros, parcelamento, zoneamento, redes de infraestrutura, sistemas de áreas livres e plano detalhado do centro cívico, além de documentos como memoriais, cadernos de encargo para os edifícios das quadras centrais, legislação edílica e urbanística e até diretrizes para organização administrativa. Ainda conforme o contrato, ficaria à cargo de Corrêa Lima o projeto arquitetônico dos primeiros edifícios, como o Palácio do Governo, a Secretaria Geral do Estado, um hotel com 60 quartos, algumas residências-tipo para funcionários, entre outros (MONTEIRO, O. S. N., 1938).

Attilio seria responsável, portanto, por imprimir àquela nova cidade nas imediações de Campinas sua primeira fisionomia. Numa espécie de gesto fundador de uma capital que se ergueria ex nihilo, o urbanista vislumbraria o local de implantação do núcleo pioneiro (deslocando-o em relação ao sítio indicado pelo engenheiro João Argenta, profissional que também participara da mencionada comissão) e, in loco, fixaria em meio à retorcida vegetação do cerrado o exato ponto a dispor sua pedra fundamental, capturado num

Daher (2003) e W. A. Medeiros (2014), só passaria a ser preenchida a partir da década de 1980, através de monografias percussoras como Goiânia: 50 anos, de Graeff (1985), Goiânia: evoluções do plano urbanístico, de Cordeiro (1989), Goiânia: embasamentos do plano urbanístico original, de Cordeiro e N. Queiroz (1990) e, na sequência, obras como as de Manso (2001), Gonçalves (2002), Daher (2003) e Ribeiro (2004). Há, ainda, trabalhos cujo tema central não é Goiânia, e sim trajetórias profissionais, mas que oferecem expressivos aportes, como a dissertação de Diniz (2007) e das teses de Ackel (2007) e Manso (2018).

${ }^{18}$ Em que pese o fato do Censo de 1920 não distinguir a população urbana da população rural, Palacín e Moraes (1977/2008) sugerem que grande parte dos 35 mil habitantes de Catalão não estava necessariamente estabelecido no núcleo citadino, e sim disposto pelas fazendas e sítios da região. 
emblemático registro fotográfico - como uma certidão de nascimento. Aquele seria o marco inicial da construção de uma urbe moderna em pleno sertão. Corrêa Lima posteriormente relembraria este momento, diante das vicissitudes de uma cidade nova: no lugar de "largas avenidas arborizadas, ainda não faz uma década, pastavam, disciplinarmente, bando de emas e corvos campineiros. E foi uma ossada de ema que me serviu para localizar o marco zero da cidade" (GOIANIA..., 1942, p. 3).

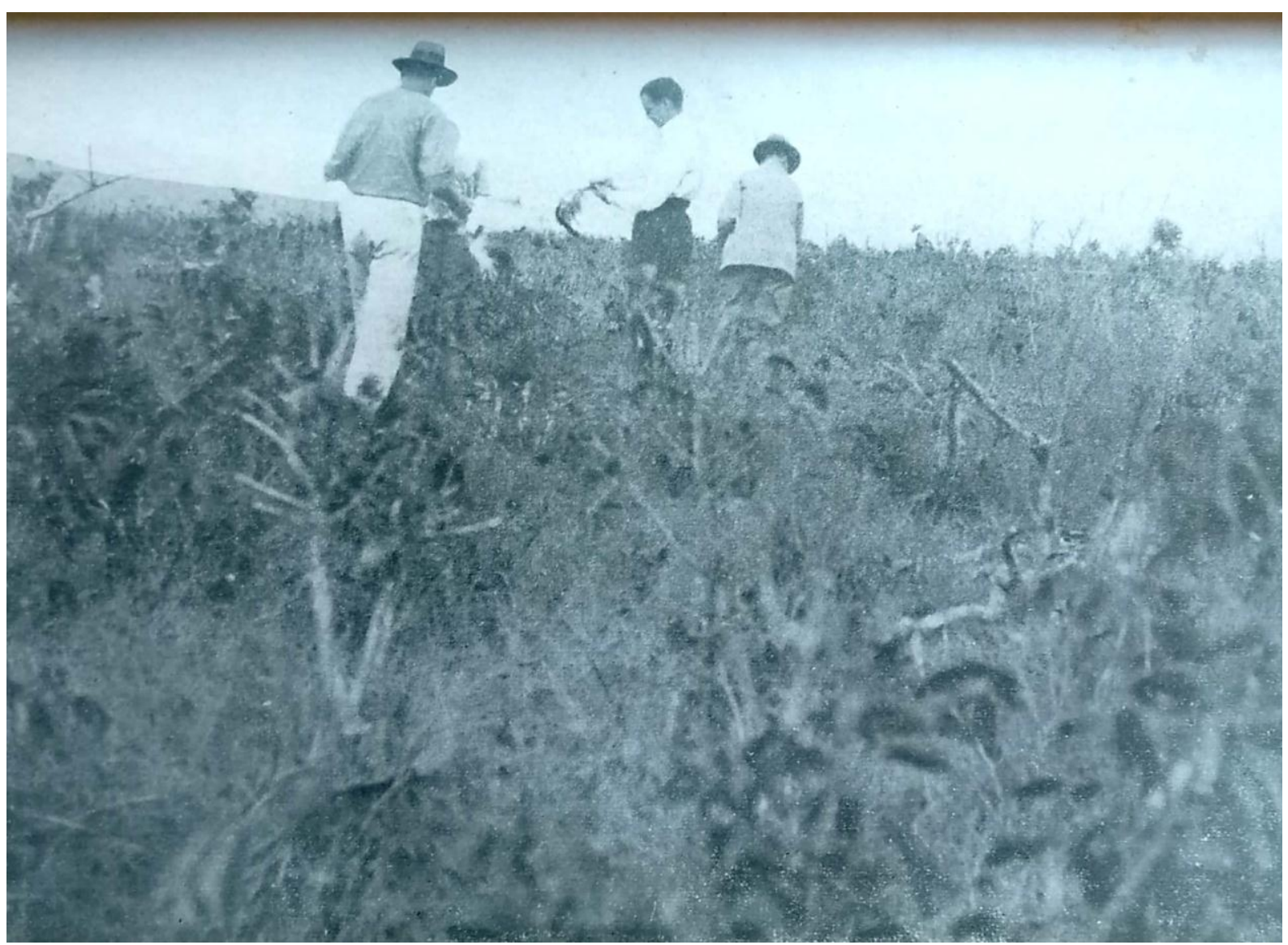

Figura 4: "A fixação do núcleo central da nova capital - o urbanista Correia Lima, o que se vê no centro, determina o local onde deve ser colocada a pedra fundamental do Palácio do Governo". Legenda da publicação. Autoria: desconhecida. Fonte: IBGE (1942).

Em seu plano, Attilio Corrêa Lima (1935/1942, p. 47) idealizaria um traçado como resposta “à configuração do terreno, à necessidade de tráfego e ao zoneamento". Permeado por um sistema de espaços livres, aos diferentes padrões de malhas reticuladas seriam incorporados extensos eixos diagonais, bem como radiais de múltiplas escalas, gerando encontros oblíquos que realçariam os elementos dispostos em suas proximidades. Sob herança da escola francesa de urbanismo, advinda de sua formação acadêmica e profissional, Attilio explicitamente denotaria o influxo de princípios urbanísticos clássicos. Assim, ao se amparar em exemplos baseados numa conformação radial, o urbanista lançaria mão de amplas 
perspectivas, da escala monumental de vias e áreas abertas e mesmo do relevo para destacar o principal motivo da cidade, seu centro administrativo.

Quem atravessar a cidade ao longo da sua principal via comercial (avenida Anhanguera), verá sucessivamente três pontos de vista diversos ao cruzar três grandes avenidas que convergem para aquele centro. Procuramos adotar o partido clássico de Versailles, Carlsruhe e Washington, genericamente chamado de "Pate d'oie" pelo aspecto monumental e nobre, como merece a capital de um grande Estado (evidentemente que guardando as devidas proporções) (LIMA, A. C., 1937/1942, p. 100)

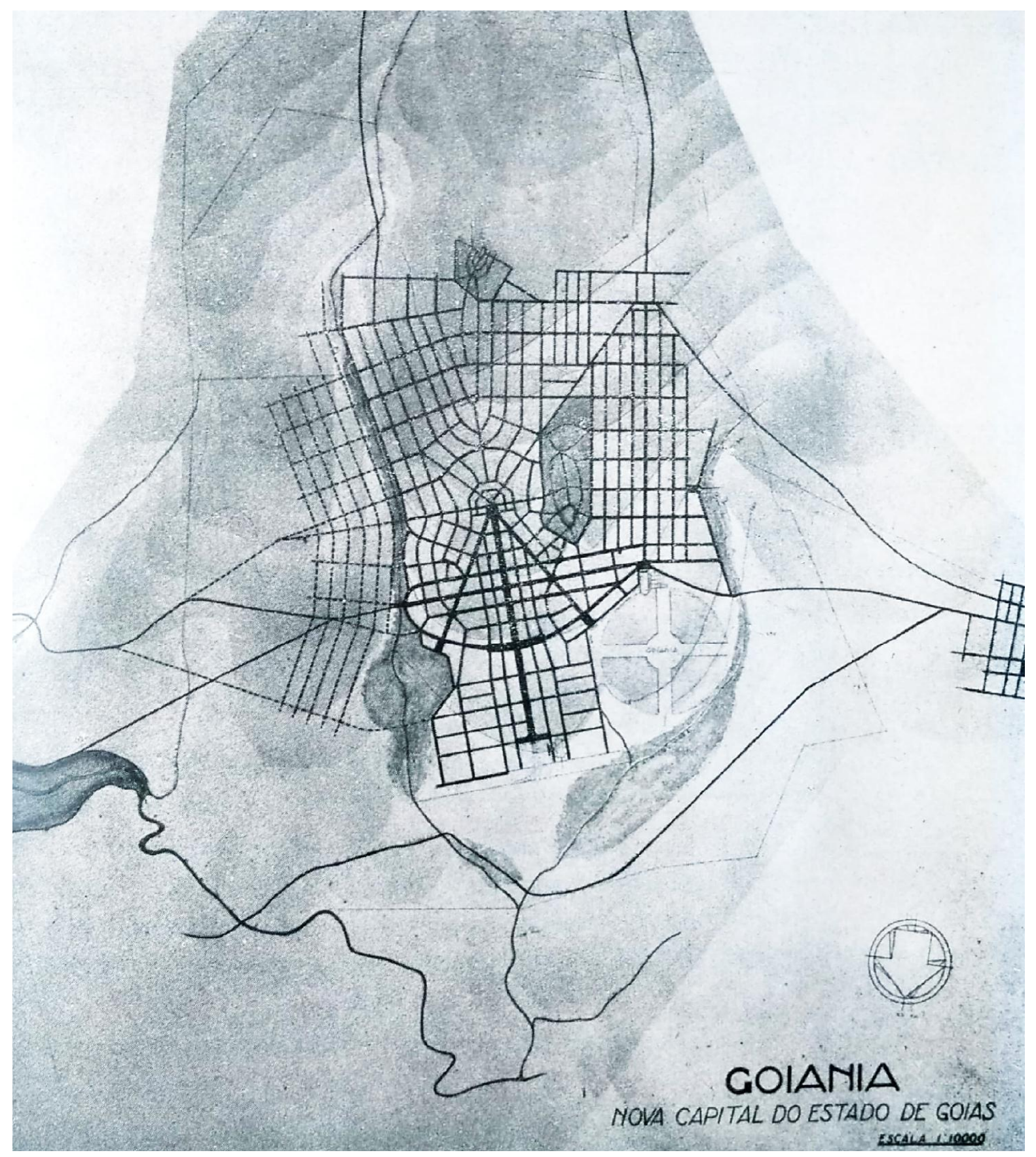

Figura 5: "Planta da cidade. Projeto do arquiteto urbanista Atilio Correia Lima". Legenda da publicação. Fonte: IBGE (1942). 
Não deixa de chamar atenção que a cidade de Attilio, idealizada como símbolo de progresso, adotasse feições que poderiam evocar "mais qualquer coisa do tempo de [Pierre] L'Enfant do que da idade da máquina" - embora contasse "com muitas ruas bem largas e bastante espaço livre e aberto", segundo Goodwin (1943, p. 96). Percepções como essa, contudo, devem ser relativizadas, pois são fluídas à medida que mudam seus enunciadores. Ao mesmo tempo, a contumaz discussão sobre o quão "barroco" seria o plano de Goiânia carrega consigo uma tendência ao anacronismo, sobretudo diante de juízos posteriores, uma vez que a concepção urbanística da nova capital de Goiás, alinhada a diversos debates urbanísticos que ocorriam internacionalmente, em geral era capaz de dar corpo ao discurso modernizante da época. Deste modo, se Bruand (1973/2016) sintetizaria que "a indiscutível inspiração de caráter histórico constatada não impede que o plano de Goiânia surja como uma criação original, que leva em conta os fatores locais e da vida moderna”, contemporaneamente à construção da capital seriam usuais as leituras que a apreenderiam como uma cidade "lindamente traçada, segundo os modernos planos urbanísticos” (GOES, 1944, p. 13).

Com menos de três anos de existência já possui 700 prédios modernos, bonitos e elegantes, dispostos nos diversos bairros que obedecem a um magnífico traçado de urbanismo perfeito em que se atende a todas as condições necessárias para a vida: higiene, conforto e beleza. (GOIÂNIA..., 1939)

Paralelamente, é interessante notar também como o grafismo do traçado em patte d'oie concebido por Attilio é absorvido e transformado pelo imaginário social. Se hoje ainda é comum a alusão ao manto de Nossa Senhora, crendice quase tão vetusta quanto persistente, não seria menos curiosa a metáfora de Vitor de Carvalho Ramos (1944, p. 29) - irmão de Hugo de Carvalho Ramos -, que faria referência à figura de um arco de uma índia goiá, “distendido, pronto a disparar a seta, rumo do futuro". O escritor Bernardo Élis, primeiro goiano membro da Academia Brasileira de Letras, também sinalizaria uma interpretação própria diante do traço do urbanista.

Coisas nunca antes vistas nem sabidas estavam acontecendo. A nova cidade de Pedro Ludovico seria feita obedecendo a um plano muito estranho engendrado e desenhado por homens de grande saber e competência. Seu autor era um dos urbanistas mais famosos do Brasil inteiro, recém-chegado da Europa, o famanaz Atílio Correia Lima. Na verdade, o plano era um trem besta: uma teia de aranha. Apesar disso, a fama do plano é de assombrar. Do Rio de Janeiro veio uma comissão de técnicos célebres especialmente para examinar a teia de aranha. (ÉLIS apud GOIÂNIA, 1985, p. 49)

De qualquer maneira, em meio às posteriores revisões do plano inicial empreendidas pela Firma Coimbra Bueno, a adoção deste partido seria criticada. Armando Augusto de Godoy, por exemplo, chegaria a declarar numa palestra que "as exigências da cidade moderna não permitem o denominado traçado clássico. Outrora não havia a influência de certos fatores 
e estudos feitos nos últimos lustros" (GODOY, 1937 apud ACKEL, 2007, p. 149) - em especial, o automóvel, que impactaria significantemente as estruturas das cidades.

Não se pode afirmar, contudo, que Attilio não estava atento aos debates urbanísticos correntes - ou às necessidades da civilização industrial, ou especificamente à questão do tráfego, como explicitaria em seus estudos. No seu artigo publicado na revista Arquitetura e Urbanismo, o urbanista esquadrinharia algumas decisões assumidas no plano, como a idealização da Avenida Paranaíba na condição de um anel viário - desviando o tráfego daqueles que potencialmente atravessariam a cidade por meio da Avenida Anhanguera -, a aplicação do sistema giratório em praças e cruzamentos principais - "o mais adequado para evitar conflitos de veículos, exigindo menor número de inspetores de trânsito" (LIMA, A. C., 1937/1942, p. 104) - ou mesmo o zoning, "procurando satisfazer as tendências modernas, de localizar os diversos elementos da cidade em zonas demarcadas [...]" (LIMA, A. C., 1937/1942, p. 101). O zoneamento de Goiânia, inclusive, habitaria leituras tecidas por Claude Lévi-Strauss e Pierre Monbeig.

Sem desconhecer as dificuldades pode-se pensar que seja uma alegria para um arquiteto o dispor de uma vasta superfície plana e docemente inclinada para aí traçar uma cidade moderna. Os construtores de Goiânia urdiram um plano inspirado no mais perfeito zoning: zona residencial, zona administrativa, bairro de diversões, zona comercial, bairro industrial tudo isso está bem delimitado. (MONBEIG, 1938/1942, p. 77)

Outro importante aspecto do plano inicial também mencionado por Monbeig - e que se fixaria à imagem da cidade - diz respeito às áreas verdes. O geógrafo ressaltaria que a cidade fora pensada envolta num cinturão florestal, de sorte que não seria "menor mérito dos urbanistas de Goiânia o transformar uma paisagem desolada em amável arvoredo, em cuja clareira respirará uma capital” (MONBEIG, 1938/1942, p. 77). Concomitantemente, a questão recorrentemente apareceria em artigos da época - de exultações a justificativas quanto ao atraso de providências.

Também concorre para a pureza do clima a proximidade de matas, as quais constituem uma necessidade nas vizinhanças de um centro urbano, pela sua salutar influência sobre as condições atmosféricas. As largas avenidas, arborizadas e ajardinadas, são, também, um elemento auxiliar à doçura do clima de Goiânia, pois impedem que os raios solares infiltrem-se pelo solo, tornando as noites frescas e agradáveis. Podemos dizer, finalmente, que quanto ao clima, Goiânia nada deixa a desejar. (SANTANA, 1944, p. 40)

O Governo, no sentido de dotar a novel Capital das exigências modernas, tem realizado obras de vulto; [...] $\mathrm{O}$ orçamento estadual não é gordo de verbas; e a execução do plano urbanístico da cidade requer o dispêndio de elevadas importâncias. [...] A arborização de Goiânia se enquadra nas medidas que o Governo tem protelado, por outras de interesse mais geral e mais amplo. [...] Agora, no entanto, vão ser intensificados os serviços de arborização, que obedecem a um plano original e de particular beleza. Goiânia está, por isso, de parabéns. (BROWN, 1939) 
Em seu plano, sem mencionar de forma explícita filiações ao ideário das cidadesjardim - embora o tenha feito no projeto-tese para Niterói (LIMA, A. C., 1932/1933) -, Attilio Corrêa Lima (1937/1942, p. 105) idealizaria a nova capital "dentro do critério moderno que manda prover às cidades de áreas livres plantadas”, reservando substancial área de seu núcleo para parques urbanos e suburbanos, espaços recreativos e desportivos, jardins e parkways. Sobre as reservas ambientais, o urbanista seria enfático ao alertar que "embora só muito mais tarde possa a administração transformar essas matas em parque, nem por isso poderá dispor delas para outros fins que não os previstos" (LIMA, A. C., 1937/1942, p. 106). $\mathrm{O}$ atendimento dessas diretrizes, de acordo com os cálculos de Attilio, garantiria uma relação de habitantes por hectare de parques ou jardins bastante vantajosa, em comparação a diversos centros urbanos como Detroit, Paris e São Paulo - mesmo se considerado o alcance do teto populacional de 50.000 habitantes.

Adicionalmente, Corrêa Lima ainda recomendaria que todas as vias públicas fossem arborizadas e as principais avenidas fossem ajardinadas. No caso do eixo central, a Avenida Pedro Ludovico (logo depois denominada Avenida Goiás), o urbanista a conceberia como uma ampla avenida-jardim com fins que não se limitariam à circulação, mas também voltados à prática de footing e celebrações cívicas. Farta e cuidadosamente arborizada, suas proporções ressaltariam seu caráter monumental.

Se as arborizadas vias e o pitoresco paisagismo seriam elementos contumazes, por exemplo, nas cenas urbanas registradas pelas lentes das câmeras fotográficas, não deixa de chamar atenção como a paisagem silvestre dos arredores similarmente se consolidaria como uma faceta da cidade. No entanto, diante da possibilidade de suas leituras remeterem mais ao sertão ou ao campo, se atribuiriam às fotografias um sentido próprio por meio de legendas, sugerindo a presença de uma exuberante natureza local como um desígnio urbanístico meticulosamente planejado. O urbanismo, por conseguinte, seria capaz de fornecer um novo matiz à paisagem sertaneja.

Entre as pranchas do Álbum de Fotografias sobre o Planejamento e Construção da Cidade de Goiânia, figuraria uma tomada da região onde hoje se situa o Bosque dos Buritis. Destaca-se em meio à rasteira vegetação a espécie de arecácea que dá nome ao parque, bastante comum em Goiás, cujos traços verticais e escultóricos a diferenciariam de agrestes descampados - não por acaso, essa seria uma das espécies representadas no pictórico desenho de Thomas Ender (figura 3). No álbum, a fotografia viria acompanhada de uma descrição que informaria sobre a importância da manutenção desses espaços, uma vez que os pitorescos 
bosques confortariam a vida da cidade com boa aeração e o sossego da natureza virgem (NETO, 1937/1995).

Na mesma esteira, a obra do jornalista Geraldo Alvares - irmão de Pedro Ludovico, diga-se de passagem - traria várias imagens de elementos naturais do entorno de Goiânia acompanhadas de inscrições como "o urbanista faz arquitetura modelando a paisagem" (ALVARES, 1942, p. 31) ou "o urbanista aproveita esses motivos da natureza, modelando a escultura da 'zona verde', que é a essência de um moderno Plano Regional de Urbanização" (ALVARES, 1942, p. 175). Dentre elas, constaria exatamente a mesma fotografia do Bosque dos Buritis presente no Álbum de Fotografias sobre o Planejamento e Construção da Cidade de Goiânia, com a seguinte legenda:

O Bosque dos Buritis, entre o Setor Central e Sul e o futuro Setor Oeste, é outro elemento de muito realce no Plano, com a preservação e aproveitamento da própria riqueza arquitetônica da paisagem natural, mediante alguns serviços de limpeza e traçado de caminhos para passeios e excursões, em recantos pitorescos. (ALVARES, 1942, p. 169)

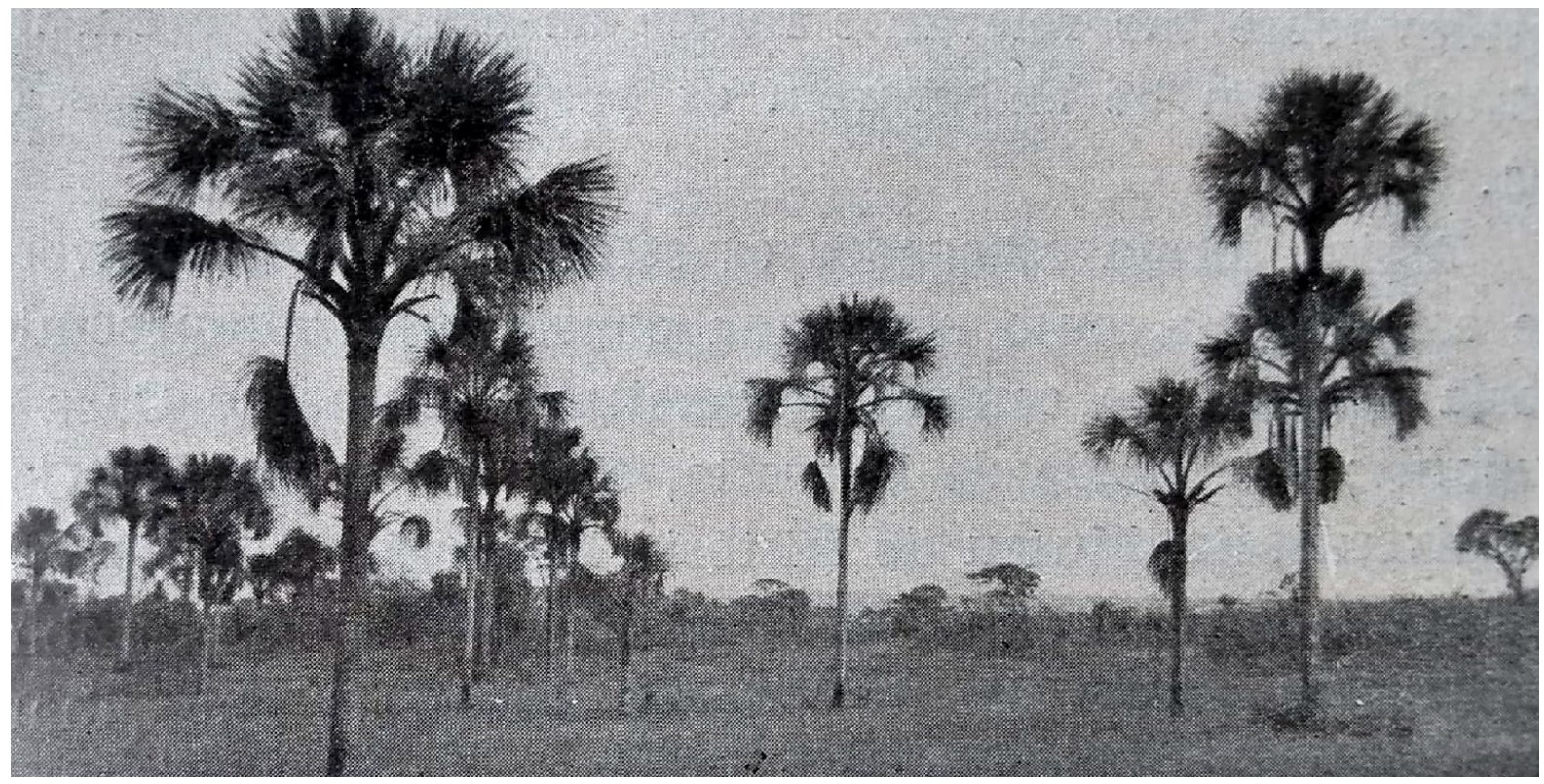

Figura 6: Bosque dos Buritis. Autoria: desconhecida. Fonte: Alvares (1942).

Attilio Corrêa Lima chegaria de fato a elaborar um estudo paisagístico para a área, concebendo-o como um parque de sinuosos percursos, pequenos lagos, pontes e cascatas, segundo Diniz (2007) - o qual não chegou a ser levado a cabo nos moldes traçados pelo urbanista. De qualquer modo, em seu relatório, Attilio também não deixaria de mencionar diretrizes para o local.

O buritizal, localizado na extremidade da rua 26, será transformado em pequeno parque. Para isso será necessário drená-lo convenientemente, conduzindo as águas pelo talweg, em canal descoberto, tirando partido deste para os efeitos de pequenos lagos decorativos. Este parque que denominamos dos Buritis se estenderá por faixas 
ao longo do talweg e medirá 50 metros para cada lado deste, no mínimo. Formando o que os americanos denominam park-way. (LIMA, A. C., 1935/1942, p. 51)

Essas e outras orientações que posteriormente mencionaremos fariam parte do plano diretor encaminhado por Attilio Corrêa Lima a Pedro Ludovico Teixeira, no início de 1935. Entretanto, uma vez que a idealização urbanística não se viabiliza de forma alheia a um complexo processo engendrado por múltiplos agentes, quase concomitantemente à entrega definitiva dos documentos, já se manifestavam anseios pela revisão de suas linhas. Num relatório remetido ao interventor, os engenheiros Jerônimo e Coimbra Bueno - donos da firma recém-contratada para execução dos serviços da nova capital - indicariam a necessidade de estender a discussão acerca do plano de Goiânia a outros profissionais, sob a justificativa de que um "trabalho de vulto deste é quase impossível a um só técnico por mais criterioso que seja, [...] atender a todas múltiplas questões que se lhe apresentam e a infinidade detalhes que lhe reclamam a atenção" (COIMBRA BUENO \& CIA LTDA., 1935 apud ALVARES, 1942, p. 12).

\begin{abstract}
No intuito de dotar a nova capital, de um plano de urbanização que esteja isento de qualquer falha, que possa, garantidamente, representar um trabalho dotado de todas as vantagens que o nível de desenvolvimento atual da técnica pode facultar, e que se garanta a expressão do mais perfeito dentro dos conhecimentos atuais, já lhe lembramos a necessidade de submeter o plano apresentado pelo urbanista Atilio Correa Lima, cujo valor nem de longe queremos diminuir, ao estudo de uma comissão composta de técnicos da maior idoneidade no assunto [...] (COIMBRA BUENO \& CIA LTDA., 1935 apud ALVARES, 1942, p. 12)
\end{abstract}

No mesmo relatório, os irmãos Coimbra Bueno (1935 apud ALVARES, 1942, p. 13) apresentariam a Pedro Ludovico alguns nomes que, "pela sua posição e valor", estariam ao nível da questão - dentre eles, Luiz Anhaia Mello, Affonso Eduardo Reidy e Armando Augusto de Godoy. Com a saída de Corrêa Lima oficializada mediante distrato contratual assinado em abril de 1935, Godoy seria convidado pelos Coimbra Bueno em 1936, de modo que voltaria a dar aporte à construção de Goiânia na condição de consultor técnico, em meio às reavaliações empreendidas pela firma a partir de então.

Há de se destacar pelos menos duas questões referentes a esse momento de revisão. A primeira é que, dada as circunstâncias, o exato papel de Armando Augusto de Godoy na idealização da nova capital de Goiás é um debate de longa data. Por um lado, o engenheiro muitas vezes apareceria como uma figura central, nominalmente responsável pelas novas feições da cidade ao atuar na adequação de um "plano primitivo", nos termos de Alvares $(1942)^{19}$, ou um “anteprojeto", uma designação utilizada nos relatórios da Firma Coimbra

\footnotetext{
${ }^{19}$ Yves Bruand (1973/2010) também utilizaria esse termo. No entanto, ao contrário de Alvares (1942), o francês daria destaque a Attilio Corrêa Lima, mencionando Armando Augusto de Godoy apenas numa nota de rodapé.
} 
Bueno em referência ao plano de Corrêa Lima - o que é refutado por Diniz (2007), haja vista que se constataria o pleno cumprimento do escopo do contrato firmado pelo urbanista. Nesse sentido, em meio a polêmicas que fogem aos limites desta dissertação ${ }^{20}$, não raramente a autoria de Attilio seria ocultada ou secundarizada em detrimento dos nomes de Armando de Godoy e dos irmãos Jerônimo e Abelardo - sobretudo diante da forte campanha de divulgação da Firma Coimbra Bueno, que se projetava sob título de "construtores da cidade de Goiânia".
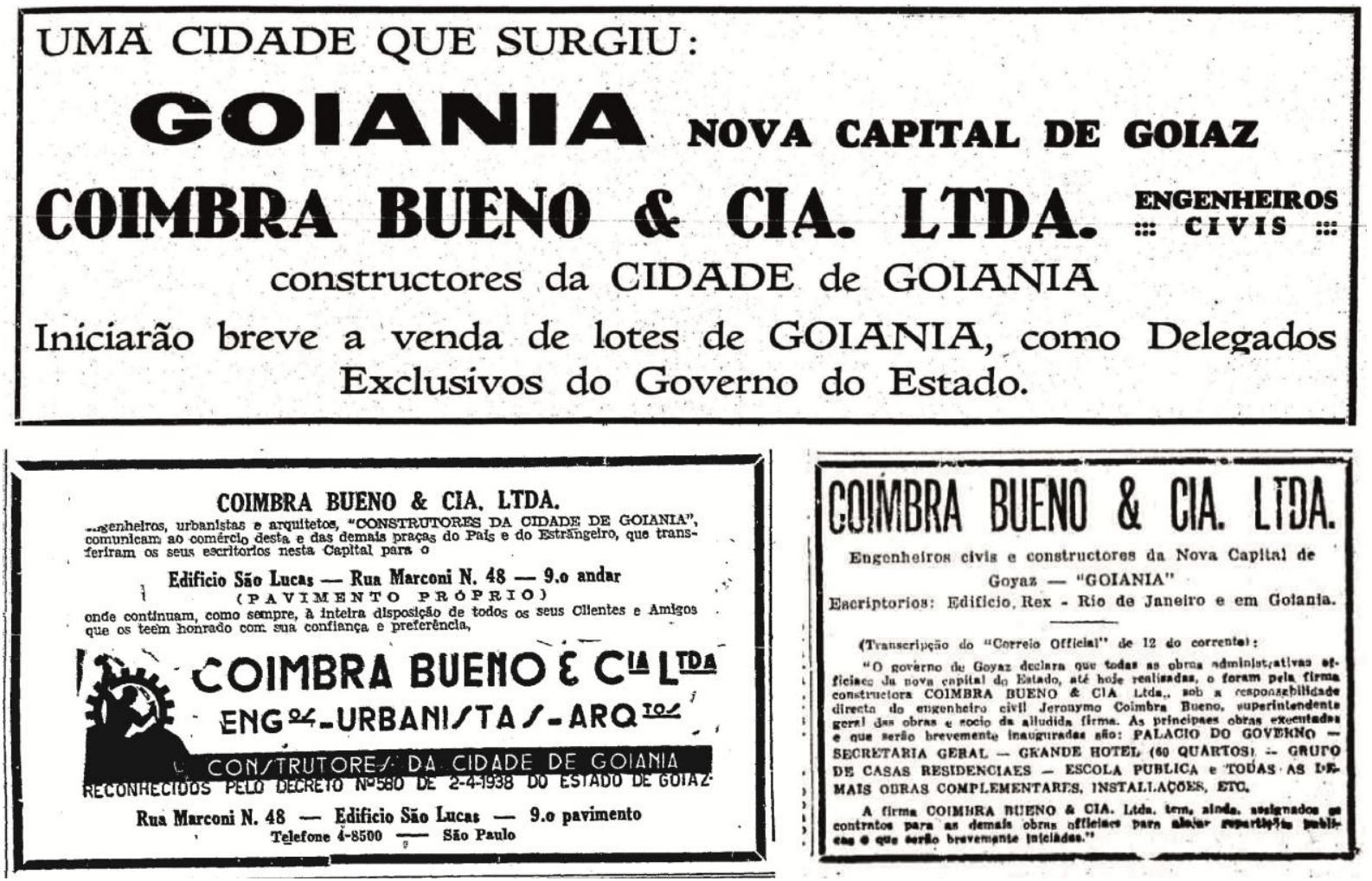

Figura 7: Propagandas da Firma Coimbra Bueno \& Cia Ltda. em jornais de circulação nacional. Fontes: O Estado de S. Paulo (1937), acima; Folha de S. Paulo (1941), à esquerda; O Estado de S. Paulo (1935), à direita.

A contribuição de Armando de Godoy como consultor entre 1936 e 1938, não obstante, sugere uma atuação indireta. Em relatórios da Firma Coimbra Bueno, por exemplo, haveria menções sobre trabalhos conduzidos internamente por uma equipe técnica (em especial o engenheiro alemão Werner Sonnenberg), enquanto a assistência fornecida por Godoy se limitaria apenas a orientações - o que eventualmente implicaria em certa morosidade nas atividades, visto que Armando não poderia dedicar "senão uma atenção secundária aos estudos de Goiânia, entre seus diversos afazeres" (COIMBRA BUENO \& CIA LTDA., 1936 apud ALVARES, 1942, p. 24).

A Zona Sul, graças à orientação do Dr. Godoy, teve o projeto feito nos moldes do subúrbio de "Redburn" [sic], que os milionários americanos construíram nas vizinhanças de New York, essencialmente para residências. Assim, projetamos, com

${ }^{20}$ Ver os trabalhos de Ackel (2007) e Diniz (2007). 
o auxílio do Dr. Werner Sonemberg, este Setor, e pretendemos projetar o "Setor Oeste" (COIMBRA BUENO \& CIA LTDA., 1936 apud ALVARES, 1942, p. 32)

Posteriormente, numa entrevista a técnicos de um órgão municipal de Goiânia - e registrada na obra de Cordeiro e N. Queiroz (1990) -, os irmãos Jerônimo e Aberlado revelariam mais detalhes acerca do processo.

Já estávamos estudando a ampliação do Setor Sul. Então nós procuramos o Dr. Armando de Godoy um dos engenheiros urbanistas da Prefeitura do Rio de Janeiro. O Armando de Godoy deu as diretrizes calçadas nas cidades americanas. Então nós, lá no Rio, começamos a projetar de acordo com os levantamentos. Praticamente o Armando não chegou a riscar nada. Ele nos deu uma revista americana. [...] Depois nós mandamos buscar uma porção de livros de urbanismo nos Estados Unidos. Armando não fez esboço nenhum. (COIMBRA BUENO apud CORDEIRO; QUEIROZ, N., 1990, p. 28)

Em suma, nota-se que a contribuição de Godoy de fato seria fundamental para que determinados traços fossem impressos à nova capital, mas não necessariamente como uma obra de autoria individual - de modo que seu nome figuraria juntamente com os de Sonnenberg e dos irmãos Coimbra Bueno no carimbo do plano de urbanização do Setor Sul. Ou seja: seu subsídio para as revisões seria, sobretudo, intelectual, articulado no campo das ideias (GONÇALVES, 2002), ao apontar diretrizes e referências urbanísticas.

A segunda questão, à semelhança da primeira, diz respeito à magnitude do papel dos irmãos Coimbra Bueno para o processo de construção de Goiânia, ainda controversa na historiografia. É sabido que Jerônimo e Aberlado, naquele momento engenheiros recémformados pela Escola Politécnica do Rio de Janeiro, tinham relações de parentesco com Pedro Ludovico Teixeira - o que justifica, em parte, a posição de destaque que assumem na condução das obras e planos da nova capital. Os irmãos ainda teriam acesso direto a Getúlio Vargas e outros nomes fortes à frente de órgãos e instituições, consolidando um prestígio não apenas técnico, mas também político - de sorte que, não por acaso, Jerônimo Coimbra Bueno chegaria a ser governador do estado nos fins da década de 1940, ao mesmo tempo que assumiria importantes funções na Comissão de Estudos e Localização da Nova Capital do Brasil.

Outro aspecto da atuação dos Coimbra Bueno que é recorrentemente evocado se relaciona às intencionalidades que motivariam as revisões do plano, onde os irmãos também representariam as pressões do capital imobiliário. Como indica Wilton Medeiros (2013, p. 118), isso se deve especialmente ao fato que, "aproveitando-se da sua condição de engenheiro responsável pela construção de Goiânia, fez incluir parte das terras que havia recebido como pagamento por seu trabalho, no Plano de Urbanização" da região da cidade-satélite de Campinas - a pequena cidade que, na ocasião, legalmente já se configuraria um bairro de 
Goiânia. No entanto, ainda segundo o autor (MEDEIROS, W. A., 2013, p. 118), se por um lado "não é possível desconsiderar a boutade imobiliária e suas consequências, na trajetória de Coimbra Bueno", não se pode minimizar a relevância dos irmãos para a consolidação de Goiânia - ou para a consolidação do urbanismo no Brasil.

É justo frisar que Jerônimo e Aberlado Coimbra Bueno detinham expressivo conhecimento técnico e estavam sintonizados com os debates urbanísticos do país e do mundo. Abelardo, por exemplo, se deteria numa entrevista em explanar as bases do "verdadeiro urbanismo" - que não se limitaria a embelezamentos e obras monumentais, mas também se voltaria à "conjugação econômico-social entre a cidade e o campo", penetrando "na seara do agrônomo, do médico, do legislador, do geo-físico, do historiador, do sociólogo, do artista" (COMO..., 1941, p. 3). O engenheiro continuaria:

Traçar uma cidade parecerá fácil. Julgam muitos até que esta tarefa se reduz, apenas,
a uma questão de topografia e de desenhos bonitos. Isto, porém, não constitui o
verdadeiro urbanismo. Os estudos preliminares, a coleta de informações seguras, a
vistoria integral de toda a região a ser estudada, sua paisagem, natureza, vias de
comunicação, origens históricas, escoamento de sua produção, enfim, todo o aspecto
morfo-fisiográfico, por assim dizer, de toda a zona - exigem cuidados especiais do
urbanista. Uma cidade não deve ser fundada a esmo, porque estaria fadada a ter vida
estacionária, senão efêmera. (COMO..., 1941, p. 3)

Concomitantemente, os Coimbra Bueno procurariam cercar-se por profissionais, em especial nomes considerados de notável saber técnico - visto que os irmãos já estavam atentos à possibilidade de atuarem na construção da nova capital federal -, para o desenvolvimento de estudos para diversas cidades brasileiras e até do exterior ${ }^{21}$. Nos projetos de Goiânia, além de Armando Augusto de Godoy, também pode-se mencionar contribuições de Salvador Batalha (que posteriormente seria um dos jurados do famoso concurso do Ministério da Educação e Saúde Pública) e Anhaia Mello (em princípio, consultado sobre o zoneamento do Setor Central), além de outros engenheiros, arquitetos, desenhistas, topógrafos e técnicos citados em relatórios e ativamente presentes no andamento das atividades.

Ademais, não se pode esquecer que a Firma Coimbra Bueno ainda contaria com Alfred Agache em seu quadro técnico. Aparentemente, o francês não chegaria a atuar no plano de Goiânia, mas posteriormente visitaria a cidade na companhia de Jerônimo, Aberlado e Getúlio Vargas, a fim de conhecer o local escolhido para a futura sede administrativa do país. As curiosas impressões de Agache sobre o projeto de Goiânia, considerada por ele a cidade mais moderna do Brasil, seriam registradas na reportagem de um jornal local.

\footnotetext{
${ }^{21}$ Aberlado Coimbra Bueno teria sido convidado a realizar estudos de urbanização para a cidade boliviana de Cochabamba, segundo reportagem do O Globo (UM URBANISTA..., 1943). Já posteriormente, nos fins da década de 1980, o engenheiro também participaria das discussões acerca do Proyecto Patagonia - iniciativa que, dentre as ações, visava transferir a capital argentina para a cidade de Viedma (EXPERIÊNCIA..., 1989).
} 
Há longo tempo conhece as plantas de Goiânia, afirmou-nos S. S., ressaltando-lhes à vista, desde o primeiro exame, a perfeita orientação técnica que lhe imprimiu, com exuberante aplicação artística, notando-se, em seus detalhes, um verdadeiro acentuado carinho. O plano de Goiânia, segundo a opinião do Prof. Agache, leva importante vantagem sobre o de uma das mais modernas cidades do Brasil - Belo Horizonte. Segundo já teve ocasião de observar, assegurou-nos o Prof. Agache, Belo Horizonte apresenta um defeito de que Goiânia não pode ter receio. Belo Horizonte obedeceu a dois planos, conforme sua expansão. O primeiro compreende a parte do centro e inicial da cidade, perfeitamente bem elaborado. E o segundo, que é o de expansão, compreendendo os arredores, destoa da parte central, oferecendo, assim, uma divergência que não passa desapercebida aos olhos dos técnicos. A preocupação de se fazer um grande traçado em Goiânia prevendo uma cidade, que em menos de cinco anos não ficará concluída, é digna de louvores - disse-nos o Prof. Agache. (EM GOIÂNIA..., 1940, p. 2)

É em meio a essa complexa trama, composta por personagens multifacetados, que se procederia, a partir de meados da década de 1930, a revisão dos traços inicialmente concebidos para Goiânia.

Convém ressaltar que, enquanto ocorriam os reestudos, o Setor Norte e principalmente o Setor Central já se encontravam em vias de estabelecimento, com obras edílicas e traçado viário em grande parte definido segundo as diretrizes de Corrêa Lima - o que acarretaria pouca margem para modificações estruturais. Logo, em linhas gerais, as ações nessas áreas se articulariam sobretudo através da reavaliação do zoneamento anteriormente proposto, incluindo uma significativa redução da zona comercial disposta entre as avenidas Goiás e Anhanguera.

Realmente, segundo os mais recentes trabalhos de urbanização, e na opinião de nossos maiores urbanistas (Dr. Godoy, Dr. Anhaia Mello, e outros), a área reservada pelo Dr. Correia Lima para o comercio, era cerca de quatro vezes maior que a indicada pelo urbanismo, considerada a cidade com toda a população para a qual era prevista. [...] Uma zona comercial muito extensa traria, como consequência, um número demasiado de estabelecimentos comerciais para a população prevista para a cidade, aumentando, assim, demasiadamente as "ofertas" em relação às "procuras". Daí, um desequilíbrio da lei de "oferta" e "procura", no comércio da cidade, funesta para o comércio e para a cidade, porque resultaria na existência de um grande número de pequenas casas, com deficiente movimento de vendas, incapazes de se desenvolverem e imprimirem progresso à cidade. (COIMBRA BUENO \& CIA LTDA., 1936 apud ALVARES, 1942, p. 29-30)

Já o Centro Cívico - sugestivamente denominado por Corrêa Lima como Praça Couto de Magalhães, em referência ao governante decimonônico mencionado na seção anterior -, apesar de concentrar as principais construções em andamento, pôde ser replanejado por ainda contar com grande área disponível. Em relação ao plano de Attilio, a Firma Coimbra Bueno suprimiria algumas edificações com o objetivo de ampliar espaços livres, sob a justificativa de que "as manifestações públicas, as reuniões cívicas, as paradas políticas e militares, necessitam de espaço para serem realizadas" (COIMBRA BUENO \& CIA LTDA., 1936 apud ALVARES, 1942, p. 33). 
Conquanto fosse quebrado o "mono-centralismo" com a inclusão de outra ampla praça no Setor Sul, conforme aponta Graeff (1985, p. 29), o Centro Cívico permaneceria como o grande marco de uma capital que ainda se projetava mais na imaginação do que materialmente. E, para facilitar a apreensão de suas linhas - sobretudo em meio à sistemática divulgação que se fazia da cidade -, seriam confeccionadas peças gráficas como plantas urbanísticas humanizadas e perspectiva em vol d'oiseau, amplamente reproduzidas em livros, periódicos, álbuns e até utilizadas em exposições.

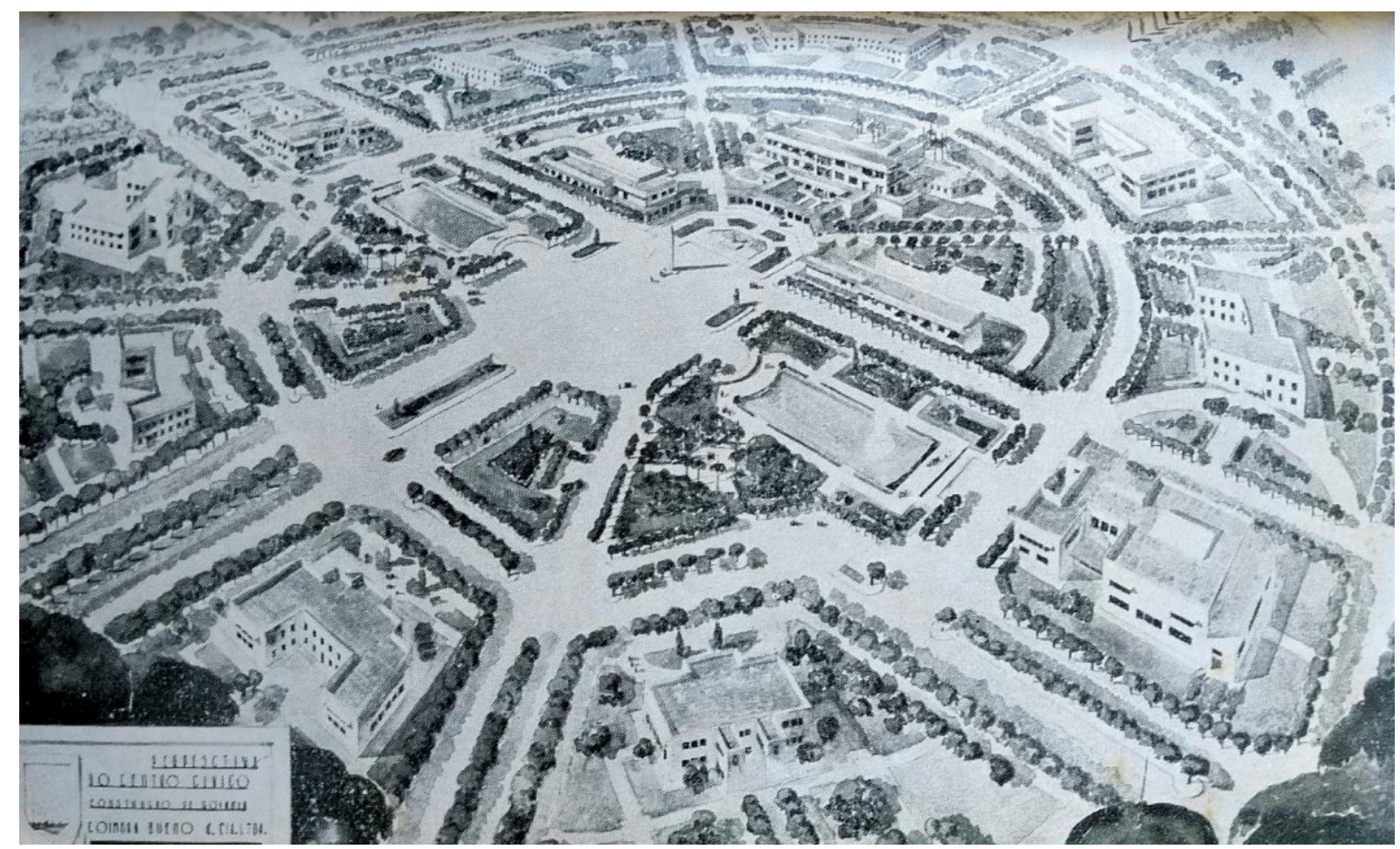

Figura 8: Perspectiva do Centro Cívico. Autoria: Coimbra Bueno \& Cia Ltda. Fonte: IBGE (1942).

A visão superior da cidade a partir do Centro Cívico ressaltaria o ponto de convergência do traçado radial, bem como a existência de generosos espaços livres, ajardinados ou não, e elementos como espelhos d'água e fontes, que conviveriam com edifícios de baixo gabarito e traços sóbrios. A vegetação ao longo de passeios e avenidas seria igualmente destacada, com diferenças em relação aos croquis de $\mathrm{Attilio}^{22}$ : ao invés de palmeiras e vegetação arbustiva disciplinarmente podada, o tratamento paisagístico da Avenida Goiás "com um renque central de árvores frondosas destruindo os efeitos de perspectiva e fechamento de perspectiva que dariam às três avenidas convergentes" (GRAEFF, 1985, p. 13) faria que o caráter pitoresco sobressaísse em relação ao monumental.

\footnotetext{
${ }^{22}$ Os croquis, integrantes do acervo da família Corrêa Lima, podem ser encontrados nas obras de Manso (2001) e Diniz (2007).
} 
Nos mesmos moldes, também se construiria uma maquete do Centro Cívico. O modelo seria registrado numa fotografia presente na obra de Alvares (1942) - num ângulo de observação coincidente ao da perspectiva.

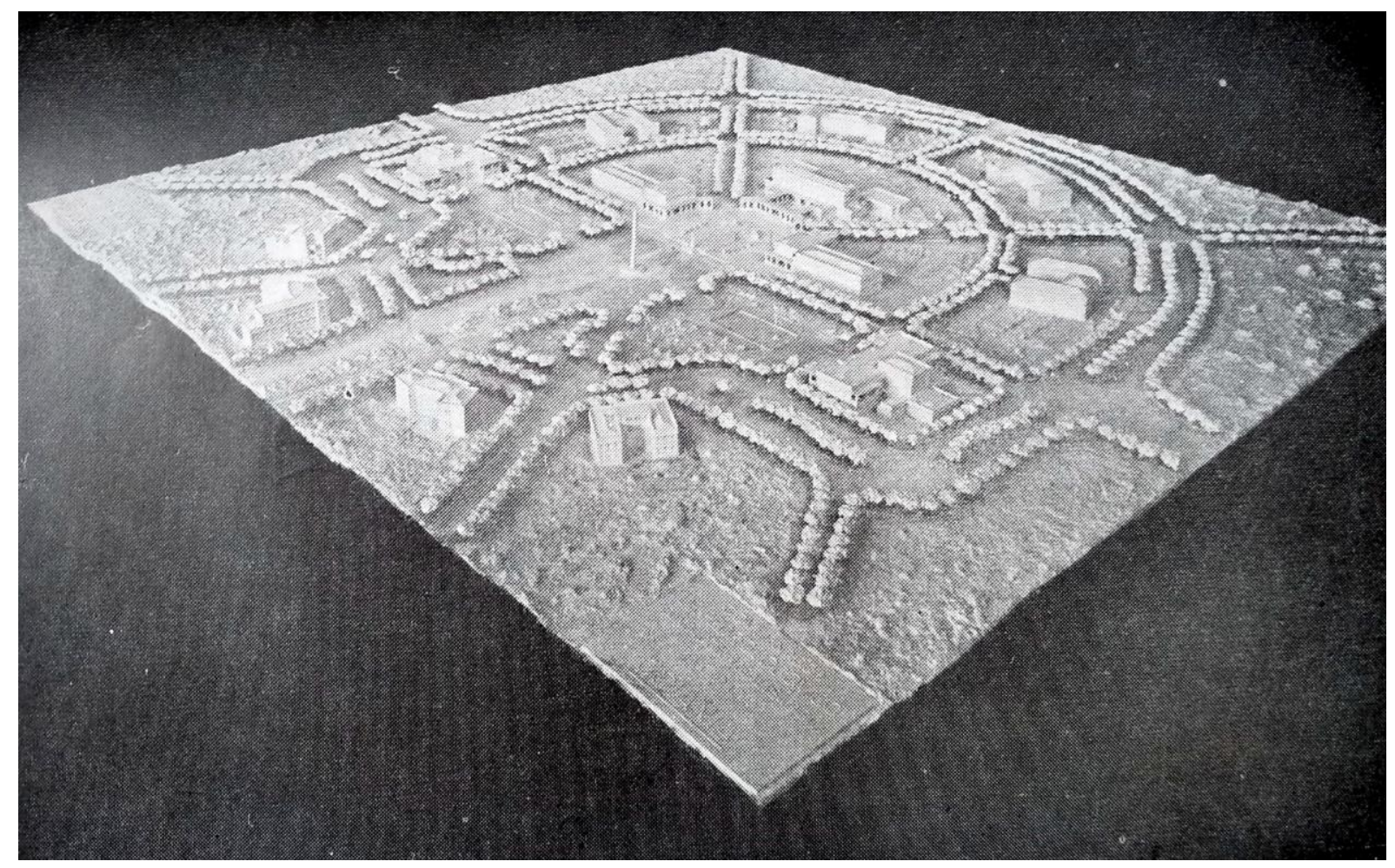

Figura 9: Maquete do Centro Cívico. Autoria: desconhecida. Fonte: Alvares (1942).

Pôde-se mapear a apresentação da maquete - juntamente com planos, perspectivas e fotografias - em ocasiões como a Feira Internacional de Amostras de 1937, realizada no Rio de Janeiro, e a Exposição de Viação e Obras Públicas de 1938, igualmente sediada na capital federal. Outrossim, há suspeitas que também poderia ter figurado numa exposição sobre Goiânia, organizada no salão da Associação dos Artistas Brasileiros, num período exatamente entre os eventos supracitados. Na Exposição de Viação e Obras Públicas, a maquete inclusive chegaria a aparecer no registro de um coquetel oferecido pelo governo do estado de Goiás à imprensa do Rio de Janeiro, logo à frente de nomes como Herbert Moses, presidente da Associação Brasileira de Imprensa - sob sua gestão se construiria o icônico edifício-sede da associação, projetado pelos irmãos Roberto -, Nero de Macedo, ex-senador de Goiás, e o engenheiro Abelardo Coimbra Bueno (O GOVERNO..., 1938).

Aliás, essa privilegiada relação com a imprensa, bem como a postura da Firma Coimbra Bueno e do governo de Goiás - sobretudo através de seu Departamento de Propaganda e Expansão Econômica do Estado - voltada à intensa divulgação de Goiânia, muito deveria às orientações que Armando de Godoy teria fornecido em seu relatório encaminhado ao interventor Pedro Ludovico Teixeira. No documento, Godoy (1933/1943, p. 
221) teria salientado a importância de uma propaganda bem dirigida para "a formação rápida de novos centros urbanos [...] no sentido de atrair capitais e habitantes".

Temos a respeito um exemplo bem eloquente na construção de Magnitogorsk pela República Russa. Trata-se de uma cidade industrial que surgiu em zona deserta. Todos os meios de propaganda foram empregados, figurando entre eles a radiodifusão, o teatro, o livro, o jornal, o cartaz, etc. Um dos efeitos foi despertar em toda parte um grande interesse em ver surgir numa zona inteiramente despovoada uma cidade moderníssima que, não obstante ter sido iniciada há menos de cinco anos, já conta com duzentos mil habitantes. A mesma coisa se observou em relação a Radburn, que é uma cidade modelar, construída de acordo com todas as exigências de tráfego e da vida moderna. (GODOY, 1933/1943, p. 221)

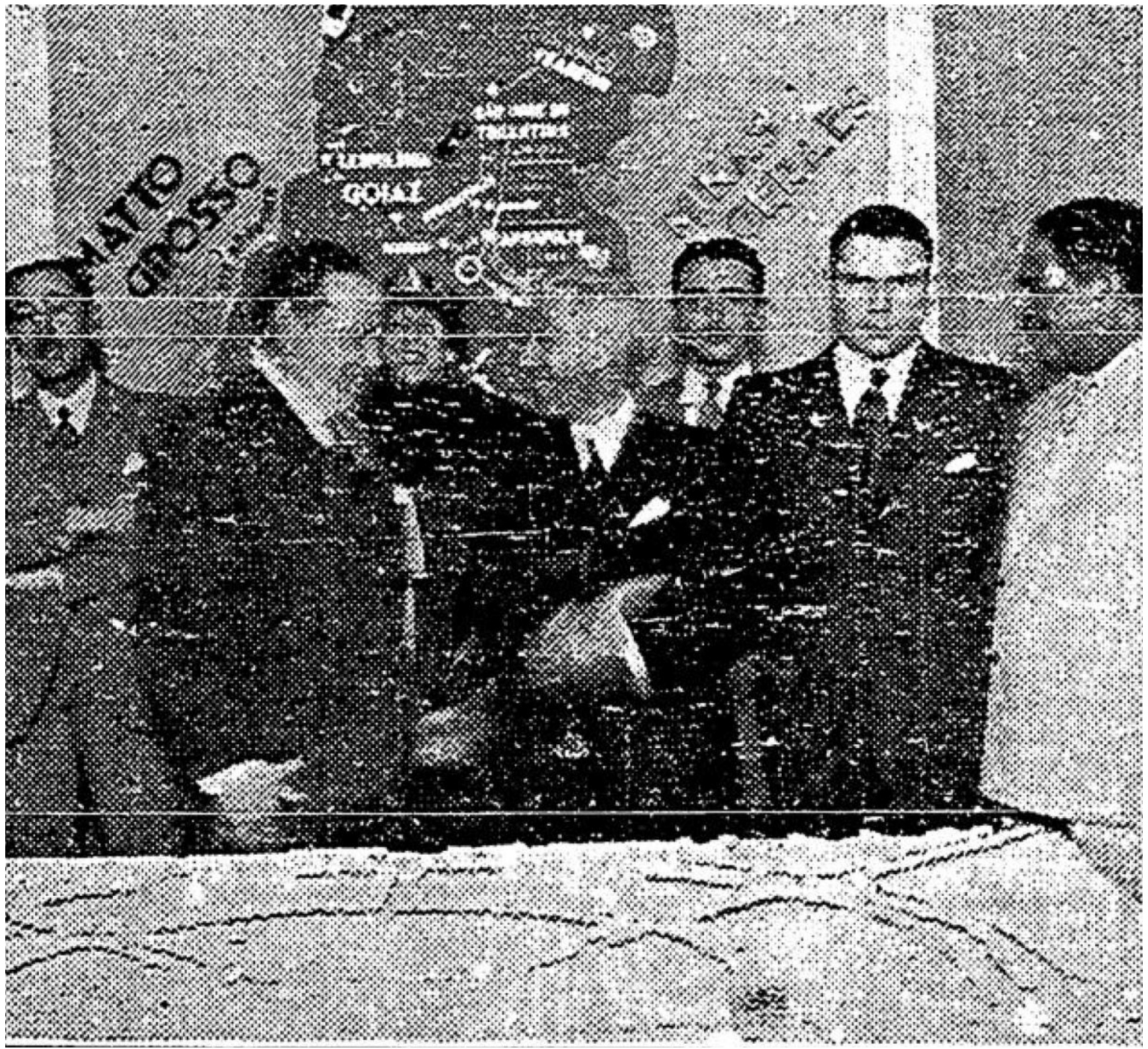

Figura 10: Maquete do Centro Cívico na Exposição de Viação e Obras Públicas, no Rio de Janeiro. Autoria: desconhecida. Fonte: O Globo (1938).

Por fim, aproveitando a menção a Radburn, deve-se destacar o maior objeto da revisão empreendida pela Firma Coimbra Bueno: o Setor Sul. Inteiramente redesenhado em relação ao projeto de Attilio - conquanto replique um esquema radial -, o plano idealizado para o bairro da nova capital seguiria os mesmos princípios empregados por Clarence Stein e Henry Wright no subúrbio americano, em resposta às necessidades impostas pela era do 
automóvel (STEIN, 1951): separação das ruas residenciais dos eixos de tráfego (com adoção de $c u l$-de-sac para atenuar o fluxo local), separação do fluxo veicular do fluxo de pedestres e a previsão de vegetação abundante, em especial no interior das grandes quadras - para onde se voltariam as frentes das casas. Num dos relatórios da Firma Coimbra Bueno, se argumentaria a favor dessas soluções.

Isto, porque é incomodo e perigoso o pedestre andar no meio de veículos, como se vê comumente. Também é mais cômodo para o pedestre andar por um parque que por uma rua. Foi, então, projetado um sistema de parques internos, limitados pelos fundos dos terrenos, que se comunica por toda a cidade afora, de forma a poderem os pedestres (sobretudo as crianças) andarem pelos parques para se locomoverem neste setor. Naturalmente que, para comunicações, não havia necessidade de todo um parque. Bastaria um beco, mas foram projetados parques para satisfazer a outras necessidades: - boa aeração que só grandes blocos de vegetação permitem, para localizar áreas para recreio das crianças, jardins de infância, escolas, campos de sport, enfim, toda uma série de confortos necessários a uma vida civilizada. (COIMBRA BUENO \& CIA LTDA., 1936 apud ALVARES, 1942, p. 32-33)

A referência a Radburn seria amplamente utilizada, como meio de conferir credibilidade ao plano de Goiânia. No texto introdutório do já citado Álbum de Fotografias sobre o Planejamento e Construção da Cidade de Goiânia, por exemplo, constaria que:

O Setor Sul, zona estritamente residencial, teve seu traçado orientado pelo Dr. Armando de Godoy, consultor técnico de urbanização de Goiânia, e possui as características das moderníssimas cidades americanas, que tem o seu modelo em Radburn. Extensos jardins e gramados, onde ficam localizadas as escolas e campos esportivos, se entrelaçam pela cidade, proporcionando agradáveis sítios de recreio. (NETO, 1937/1995, p. 2)

De acordo com o mesmo texto, os traços do Setor Sul apareceriam como distintos aos do Setor Central e Norte.

Os Setores Central e Norte, onde ficam situadas as zonas comercial e industrial, apresentam um traçado geométrico mais severo e clássico, ao molde das cidades europeias. Seus anteprojetos são de autoria do urbanista Attilio Corrêa Lima, atravessa-os a principal avenida da cidade, com 50 metros de largura e 980 de extensão. (NETO, 1937/1995, p. 2)

Em outro caso, numa entrevista a Pedro Ludovico, similarmente se mencionaria o Setor Sul e Radburn - sem deixar de citar Corrêa Lima como autor do projeto principal da cidade -, salientando o ineditismo da solução urbanística no país.

Foi também o dr. Armando de Godoi quem projetou o setor sul de Goiânia, aplicando os conhecimentos mais modernos que há sobre a matéria: só em um arrabalde de Nova York se encontra coisa igual, difícil, portanto, de ser executada, presentemente, em nosso meio. ("PORQUE..., 1942, p. 7)

Embora a efetiva implantação do Setor Sul só se iniciasse na década de 1950 - com o descumprimento de algumas premissas basilares do projeto, diga-se de passagem -, desde sua concepção o bairro já figuraria como uma das imagens de Goiânia, uma vez que sua planta seria expressivamente reproduzida e mencionada (muitas vezes, em detrimento do traçado em 
patte d'oie de Attilio). A diagramação na qual seria apresentada pelo Álbum de Goiaz, no entanto, desmembrada de uma planta geral, sugeriria outra faceta de uma cidade que ainda se esboçava e já continha em si múltiplas visões urbanísticas: era quase como se houvesse várias "Goiânias”. Como afirmaria Francis Violich:

O plano da nova capital do estado (não confundir com a capital nacional uma vez proposta para o Estado de Goyaz) representa o trabalho de vários planejadores brasileiros e três diferentes escolas de planejamento: primeiro, o pequeno povoado segue o plano em grelha de tradição colonial portuguesa; segundo, a nova seção agora completada, representando a escola francesa de diagonais e radiais, trabalho do urbanista Attilio Corrêa Lima; terceiro, a seção semelhante a Radburn projetada por Dr. Armando Godoy, distintamente norte-americana. (VIOLICH, 1944, p. 123 124)

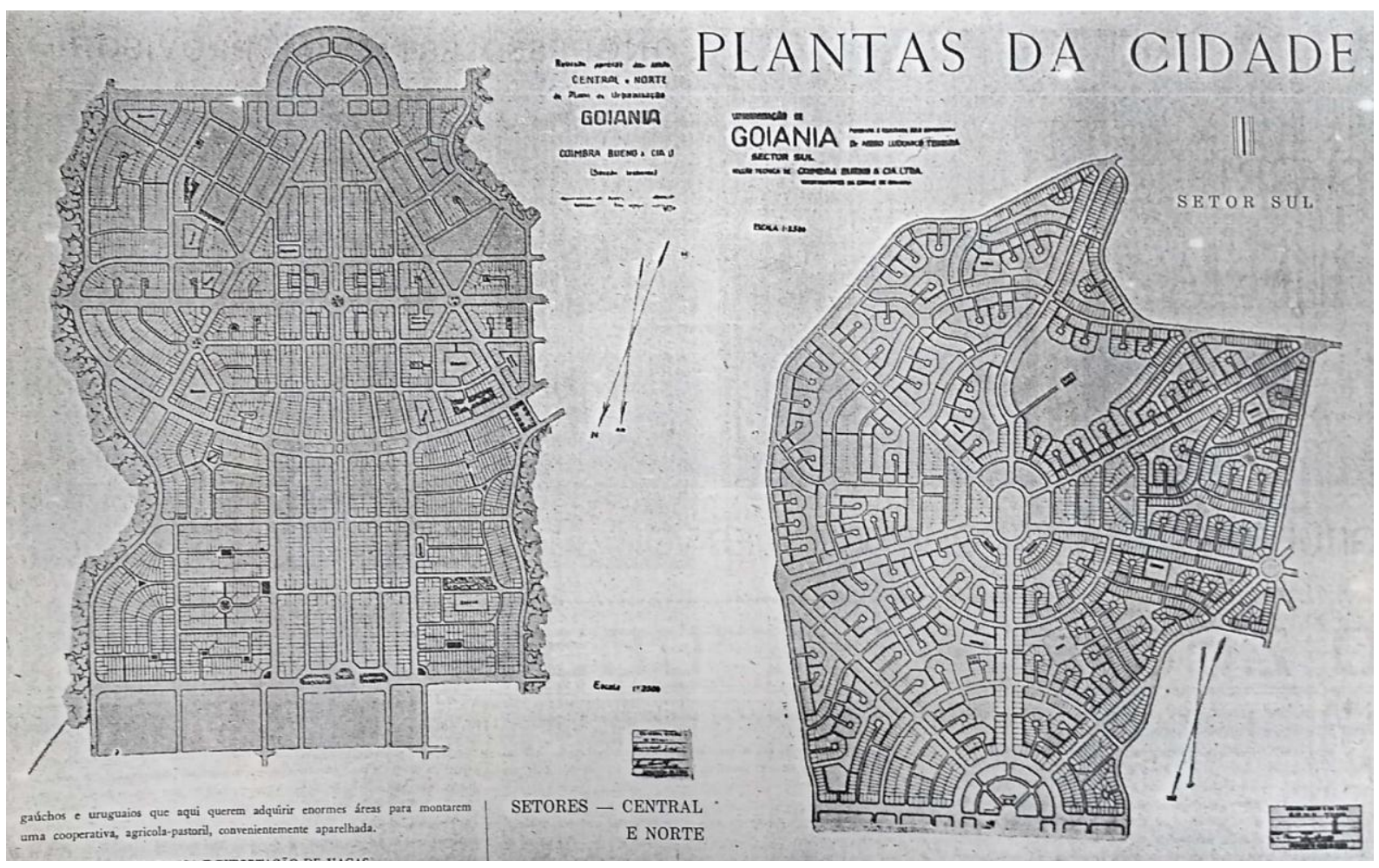

Figura 11: Plantas de Goiânia, com o Setores Central, Norte e Sul. Fonte: O. Barbosa (c. 1939)/Acervo do SEPLANH.

Assim, as linhas definidas por Attilio Corrêa Lima e revisadas pela Firma Coimbra Bueno - com Armando Augusto de Godoy e os demais profissionais da equipe técnica indicariam as feições que a nova capital deveria ter. Seguindo essas diretrizes, pelo menos a princípio, a cidade-ideia gradativamente ganharia contornos de materialidade, condensandose na cidade-concretude. Entre a idealização e a concretização, porém, haveria a dura empreitada representada pela cidade-obra - com operações igualmente complexas para erguer, física e simbolicamente, uma metrópole em pleno sertão. Continuemos, para vislumbrar mais uma faceta da construção de Goiânia. 
Cidade-obra 


\section{CIDADE-OBRA}

\subsection{A construção e as imagens do progresso}

Tudo nos dias iniciais da construção de uma cidade é mais ou menos pitoresco. A azáfama, o corre-corre dos edificadores, a curiosidade dos interessados e dos simples observadores. Isso, em meio a montões de terras e a pilhas de tijolos e telhas, tem um aspecto divertido, inusual pelo menos na maior parte da cotidianidade da vida urbana, mas em Goiânia do começo, pode-se dizer que a cor predominante era a marrom. A cor do pó, da poeira. [...] Era o festival cromático do progresso. (COSTA, G. C. apud TELES, 1986/2012, p. 108)

"Quinze dias ou um mês de ausência da atual capital goyana, basta-nos para verificar o intenso movimento existente em nossa futura metrópole" (GOIÂNIA..., 1936, p. 1). Essa afirmativa, nas primeiras linhas de uma matéria local, sinalizaria o tom de muitas outras reportagens ou relatos concernentes aos primeiros anos de Goiânia. A despeito dos embates referentes à transferência da sede administrativa, dos poucos recursos orçamentários para sua concretização e das dificuldades logísticas, o sonho, afinal, parecia consolidar-se a cada nova via aberta e a cada nova construção iniciada, diante da cidade-obra.

A acelerada velocidade da empreitada reverberava de múltiplos modos. Era comum, por exemplo, em livros, jornais e álbuns fotográficos, a divulgação de listas que indicariam não apenas o crescente número de habitantes, mas também a quantidade de estabelecimentos - de igrejas a escolas, de bancos a papelarias - ou de profissionais em atuação - de engenheiros a dentistas, de alfaiates a fotógrafos -, como sinais do desenvolvimento da urbe. Outros parâmetros próprios seriam utilizados: Artiaga (1949) chegaria a contabilizar a quantidade de clubes desportivos da capital - que, nos fins da década de 1940, já detinha seis times de futebol -, enquanto Attilio Corrêa Lima, ao comentar acerca do que observara em Campinas, empregaria um curioso exemplo para mensurar o progresso da região.

São dignos de nota os serviços de obras públicas urbanas, como meio fios, coretos e jardins onde antes eram simples pastagens. Conquanto pareça pilhéria, não podemos deixar de assinalar a introdução do sorvete. Quem conhece o interior do Brasil, sabe o que significa esse refrigerante na economia local. Não pelo valor que representa como comércio, mas como índice de progresso, por ser um gasto supérfluo. Pois bem, em Campinas existem, atualmente, três sorveterias. (LIMA, A. C., 1937/1942, p. 98)

Outrossim, o número de projetos e construções seria igualmente capaz de revelar o ascendente ritmo das obras. Em sua publicação, Alvares (1942) indicaria que a Seção de Arquitetura da Superintendência de Obras teria desenvolvido 270 projetos no ano de 1936, dos quais 73 seriam edifícios de particulares - para fins residenciais, comerciais ou mistos. Ainda segundo o autor, a partir de dados daquele mesmo órgão, este número subiria para 334 em 1937 e, apenas no primeiro trimestre de 1938, já alcançaria a marca de 136, embora 
entrassem no cálculo alguns projetos concebidos para cidades do interior de Goiás - o que confirmaria que "Goiânia estava sendo, além de Capital do Estado, um centro de irradiação educacional, que ia integrando, rapidamente, um novo 'processus' de cultura, na lentidão das velhas cidades goianas" (ALVARES, 1942, p. 123). Já Corrêa Lima indicaria que o núcleo de Campinas, próximo à capital em construção, teria "duplicado" o número de casas em poucos meses - "fato extraordinário em vista de ter sido nulo o aumento das construções nesta cidade em período anterior de 50 anos" (LIMA, A. C., 1937/1942, p. 98) -, ao passo que Otto Prazeres (1941), jornalista que anteriormente teria atuado como secretário interino de Getúlio Vargas, afirmaria que seriam justamente as cifras capazes de sinalizar a existência "de uma cidade vitoriosa bem no centro do Brasil, [...] obra de brasileiros, povoada e construída por brasileiros, criação exclusiva brasileira, êxito completo brasileiro". A modernização seria inegavelmente vertiginosa.

Uma cidade mostra-se ou revela-se, principalmente, pelo índice, pelo total ou pelo
crescer de suas construções. A nova capital de Goiaz tinha, no seu centro urbano, em
1938 - 1614 prédios. Desse ano para o seguinte, de 1939 , o aumento foi de apenas
303 prédios, subindo o total para 1959 . De 1939 para 1940, o progresso tornou-se
vertiginoso, apresentando-se neste período mais 1432 prédios, ficando a cidade com
um total de 3349 edifícios. No ano findo, portanto, segundo indicam os algarismos
que acabamos de citar, Goiânia construiu por mês mais de cem prédios, ou quase
quatro prédios por dia. Não é um crescimento: é quase uma explosão ou mais que
uma explosão se lembrarmos o marasmo goiano em época que não vai longe.
(PRAZERES, 1941)

A dinâmica que se verificaria em Goiânia, portanto, remeteria a um movimento sem precedentes em Goiás, mesmo diante de tantos óbices ao longo de sua construção.

[...] Goiânia, apesar da guerra e das dificuldades impostas na aquisição de material para construções, não se deixou contagiar pelo marasmo ou pela inércia. A metrópole do oeste avança assim a passos largos para ocupar uma posição de destaque, entre as suas congêneres no país, expandindo-se cada vez mais e crescendo assustadoramente, dando um belo exemplo de trabalho disciplinado aos olhos ávidos daqueles que a visitam. (GOIÂNIA..., 1944)

Diante da intrínseca relação que se estabelece entre o homem e o espaço - da qual deriva a atuação latente deste último como matéria-prima de símbolos e memória coletiva (LYNCH, 1960/1999) -, o ambiente em profunda transformação naturalmente se impregnaria à percepção de moradores e visitantes, de modo que seriam recorrentes as menções aos primeiros edifícios e ao aspecto de um grande canteiro que a cidade evocava. Há relatos como o da professora Celme de Mendonça (apud GOIÂNIA, 1985, p. 173) que, em seu primeiro contato com Goiânia, teria tido a impressão que a cidade "simplesmente brotava dos lotes vagos e das ruas bem delineadas", num violento ritmo de arrojo e progresso. Ou, ainda, a leitura de Augusto Bastos Morbach, que exprimiria visão similar na forma de versos: em sua 
poesia, vencedora de um concurso promovido pela Revista Oeste, Morbach conferiria vida aos vetustos buritizeiros das imediações de Goiânia, colocando-os como testemunhas do espetáculo que era a agitada construção de uma nova cidade na vasta campina, anteriormente “estirada na languida preguiça / de um silêncio sem-fim...” (MORBACH, 1944, p. 24).

\begin{abstract}
Os buritizeiros nunca haviam lido a Bíblia, / mas sabiam, por ouvir dizer, / a história da Babel. / Por isso eles acreditaram que na campina violentada / ia haver outra balbúrdia de Babel. / Aqueles homens adoidados / furavam a terra / mediam-na / zangaiavam-se com lanças bicolores, / riscavam-na toda com riscos iguais/ às estradas caprichosas das saúvas estradeiras! / Depois foram surgindo da terra ferida / daqueles riscos / daqueles cortes, / umas espécies de cupins cubados, / que cresciam / que subiam / e barravam o escampado da campina... / Eram ranchos enormes / como nunca os buritizeiros haviam visto / construídos pelos vaqueiros conhecidos. / Tiniam ferros, / zunzuneavam canções, / catiras, sambas, cantigas extranhas ... / esturgiam gritos, écos, palavriados, balbúrdia... / havia coriscos de gumes de aço refulgindo ao sol. / Era o ritmo do trabalho ritmado / ousadas concepções de avenidas e ruas... / Era a eclosão da / Metrópole sonhada, / da Metrópole Desejada / de muitas gerações! (MORBACH, 1944, p. 24)
\end{abstract}

Os numerosos exemplos recuperados até aqui, cada um à sua maneira, sintetizam um quadro permeado pelas vicissitudes inerentes ao urbano - porém, especialmente amplificadas no particular contexto de uma cidade nova. Pois, se Halbwachs (1950/1990, p. 136) indicaria que "a diferenciação de uma cidade resulta da origem de uma diversidade de funções e costumes sociais; mas, enquanto o grupo evolui, a cidade, em seu aspecto exterior, muda mais lentamente", na urbe construída ex nihilo - ou mesmo na Campininha das Flores - se experimentaria uma lógica quase inversa, uma vez que o profuso estado de transitoriedade parecia impor um compasso próprio aos surpresos olhos daqueles que permeavam o local.

Há sete anos no mesmo local havia cerrado e naquele momento cruzávamos uma cidade encantadoramente bela com todos os requisitos urbanísticos. Parecia que estávamos sonhando [...]. Em Goiânia tudo é dinamismo. O progresso é ali impulsionado por asas incontáveis. A paisagem se transforma com uma rapidez incrível. Ontem mata, hoje avenida. Ontem rio, hoje represa, usina, iluminação elétrica. Ontem macega, hoje campo de aviação, estádio. Ontem pântano, hoje bosques de eucaliptos. Ontem apertadas veredas por onde o gado desfilava. Hoje amplas estradas, largas avenidas. Tudo, assim, numa metamorfose deslumbrante. (FIGUEIREDO, J. L., 1944, p. 24)

O que seria reiteradamente expresso por meio de números e palavras similarmente se revelaria através da visualidade das fotografias, que deteria um papel central ao registrar o paulatino estabelecimento da nova capital. Entretanto, para além de sua propriedade documental, é notável como as imagens assumiriam um protagonismo próprio, em especial pela capacidade de evidenciar, de forma direta e (em princípio) fidedigna, a lépida cadência em que se dava o processo. Assim, não por acaso, o documento fotográfico seria tão utilizado para fins de publicização do empreendimento - e na construção de narrativas -, sobretudo no bojo de um distinto momento político que se experimentava local e nacionalmente. 
Duas tomadas aéreas publicadas na coletânea do Instituto Brasileiro de Geografia e Estatística (1942), por exemplo, demonstrariam com clareza a expansão de Campinas percebida por Attilio Corrêa Lima - leitura que, de alguma forma, similarmente aparenta derivar de um sobrevoo: separadas entre si por apenas um ano, a primeira fotografia retraria a cidade ainda limitando-se à região da Praça Joaquim Lúcio e Praça Santo Afonso, enquanto a segunda, de 1935 (ano que Campinas legalmente se incorporaria ao município de Goiânia), mostraria um núcleo espraiado e em franco crescimento, principalmente ao longo do eixo hoje denominado Avenida 24 de Outubro - em direção ao local onde se construía Goiânia.

Apesar de todo esse progresso, é de notar que Campinas, distando apenas cinco quilômetros de Goiânia, será no futuro apenas um dos seus arrabaldes mais importantes. Formada por uma quadrícula de ruas relativamente modestas, desenvolvendo-se em torno de uma praça, onde se acha a igreja e um convento de freiras, com o advento da nova capital, sua estrutura urbana modificou-se sensivelmente. Na extremidade sul, onde está o largo da Cadeia, por uma estrada larga e reta, que se comunica com a nova capital, formou-se um extenso tentáculo, desenvolvendo-se toda a cidade nesta direção. (LIMA, A. C., 1937/1942, p. 98)
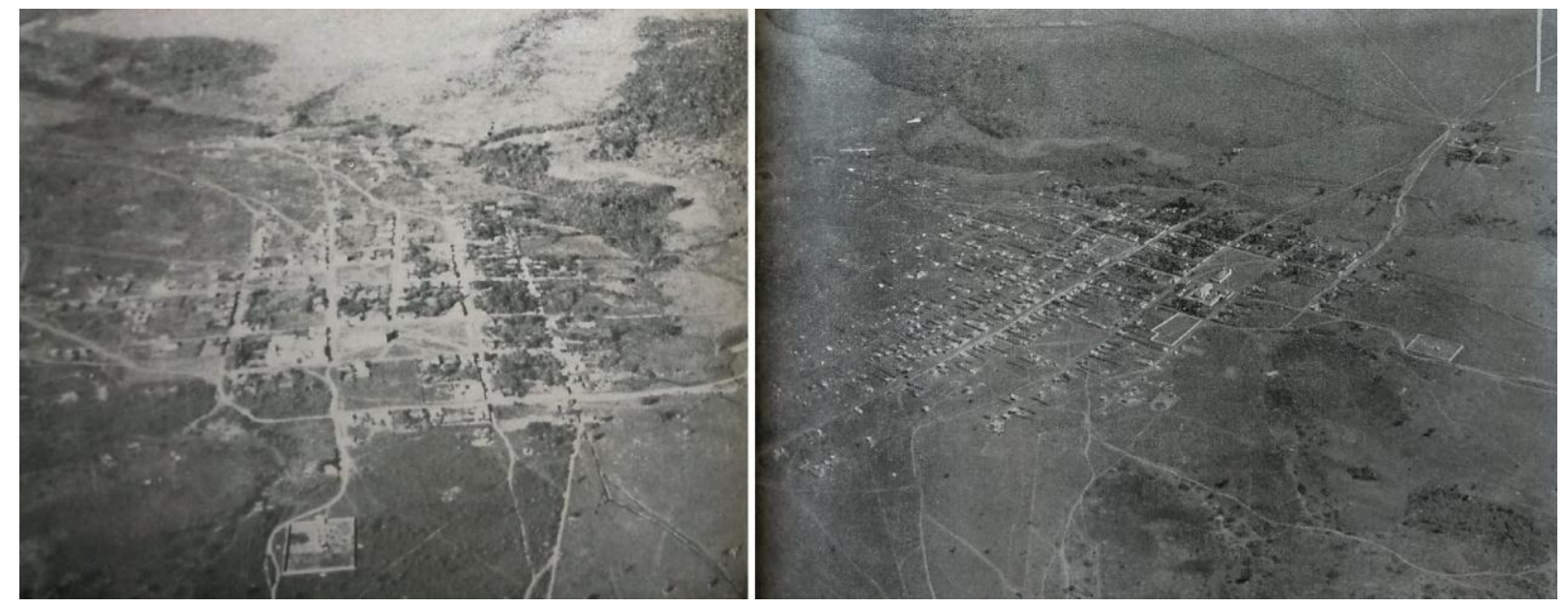

Figura 12: Campinas entre 1934 e 1935. Autoria desconhecida. Fonte: IBGE (1942), modificado pelo autor.

Semelhantemente aos registros do núcleo vizinho preexistente, os levantamentos aéreos possibilitariam apreender a implantação do novo núcleo, cujas primeiras linhas visíveis se refeririam ao patte d'oie de Attilio - transpostas ao solo como que num gesto único. $\mathrm{O}$ Álbum de Fotografias sobre o Planejamento e Construção da Cidade de Goiânia traria três fotografias em sequência, capturadas entre 1935 e 1937, para demonstrar a evolução da cidade "nascida na campina virgem, gerada e criada sob a mais rigorosa e atenta assistência técnica, dotada de todos os benefícios da moderna ciência urbanística, protegida por excelente plano diretor" (NETO, 1937/1995, p. 3). Em que pese a baixa qualidade das imagens, é possível identificar que em 1935 já estariam demarcados o local do Centro Cívico, os principais eixos radiais (Avenida Tocantins, Avenida Araguaia e Avenida Goiás), a malha reticulada do Setor Central e o campo de aviação - um elemento ressaltado nos estudos de Corrêa Lima e que 
curiosamente precederia a estação ferroviária, sobretudo diante da necessidade de tornar acessível a capital que, nos seus primeiros anos, ainda não contaria com trilhos de ferro.

O Aeródromo, foi por nós projetado e construído, quando ainda havia descrença na possibilidade da ida de aviões ao local. Confiantes no papel que cabe à aviação, principalmente para as longas distâncias e acesso difícil, e, conhecendo a deficiência dos campos de pouso existentes no Estado, empreendemos a construção, relativamente simples, dada as condições do terreno. Consta o campo de duas pistas que cruzam norte-sul e este-oeste, aproximadamente com 100 metros de largura e 1000 de extensão. (LIMA, A. C., 1937/1942, p. 109)

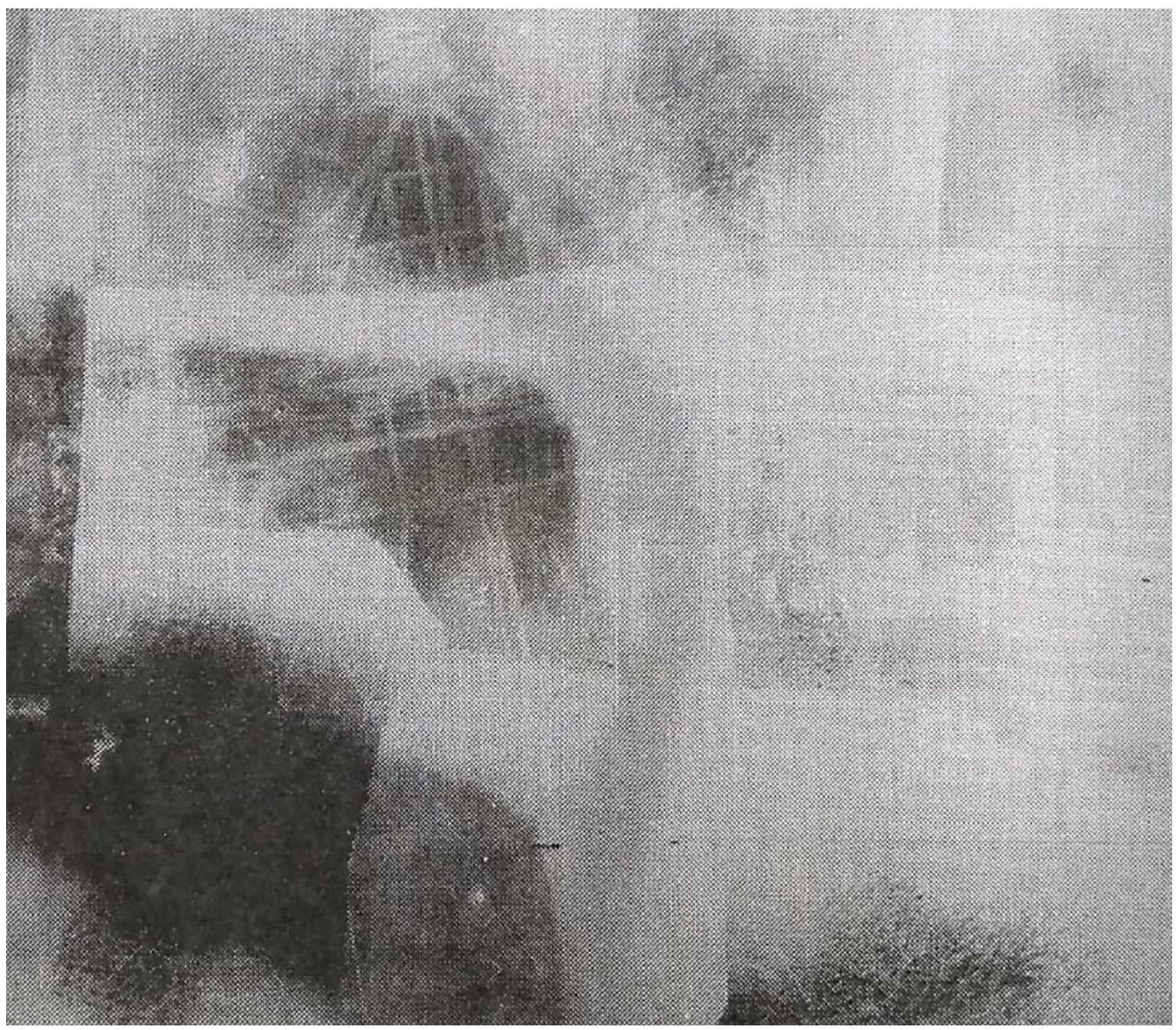

Figura 13: Levantamento aéreo de 1935. Escola de Aviação Militar. Fonte: Neto (1937/1995)/Acervo do MIS/GO.

Diferentemente da primeira fotografia, o levantamento aéreo de 1936 seria ampliado através da combinação de várias tomadas, abarcando assim o núcleo de Campinas - que se ligava às obras da nova capital por meio de uma estrada de terra. Além da execução de novos elementos no núcleo em formação, como o traçado em arco da Avenida Paranaíba, chama atenção a inclusão de frases nesta prancha do álbum - legendas que sinalizariam o progresso das atividades, mas também contribuiriam para a sedimentação de determinados nexos, como de uma cidade erguida subitamente. Dentre elas, têm-se "Cresce o Arraial de Campinas", 
“...Os esboços das ruas se definem”, “...Construções semeadas vão surgindo” e “...A Campina vai-se transformando em cidade" (NETO, 1937/1995, p. 10).

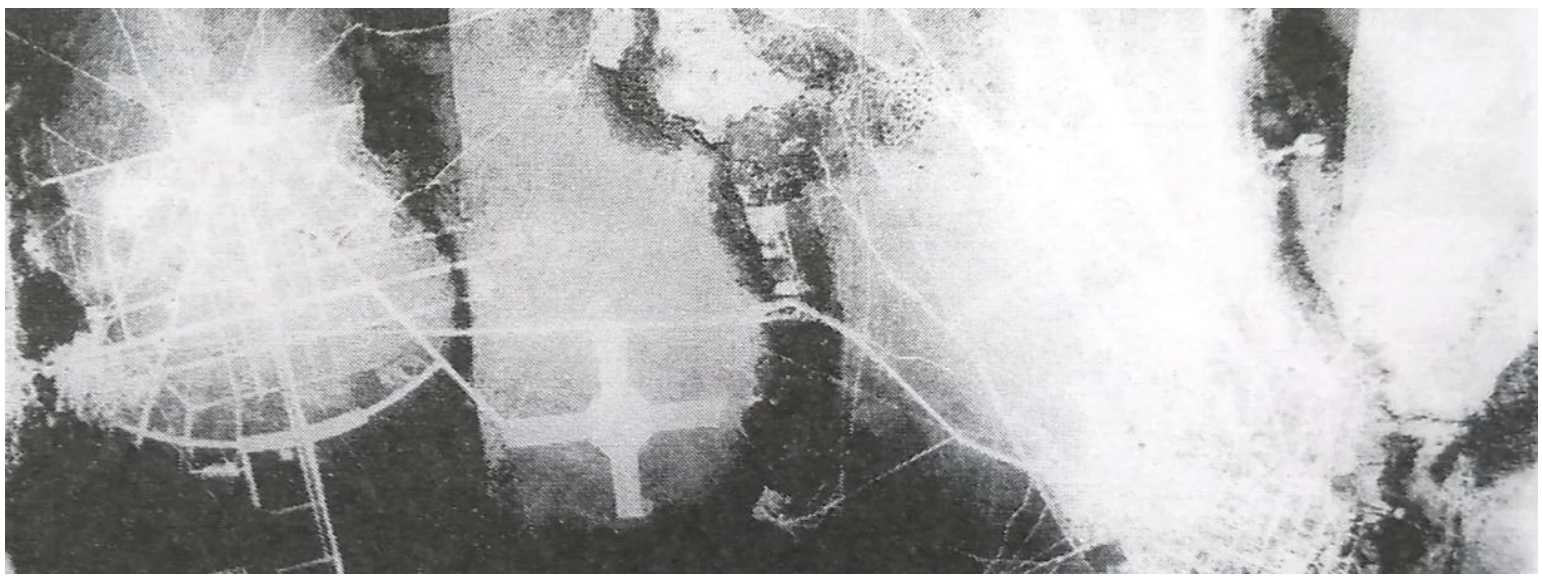

Figura 14: Levantamento aéreo de 1936. Escola de Aviação Militar. Fonte: Neto (1937/1995)/Acervo do $\mathrm{MIS} / \mathrm{GO}$.

A terceira fotografia da sequência, de 1937, mostraria com maior nitidez o processo de adensamento no novo núcleo, com suas obras concentradas especialmente na região do Centro Cívico e nas imediações da Rua 20 (onde se encontrariam as residências-tipo para funcionários do governo). É possível notar, ainda, o esboço das retangulares quadras do Setor Norte, com algumas edificações nos locais que seriam denominados Bairro Popular e Vila Militar, bem como a presença de ocupações nas proximidades do Córrego Botafogo - área que abrigaria construções pioneiras da cidade, de caráter provisório. Como na prancha anterior, a fotografia viria acompanhada de frases como “...Os três anos de trabalho foram fecundos”, “...As ruas se alastram”, “...No lugar da campina 8500 hab. (em 1934 no Arraial de Campinas 900 hab.)" (NETO, 1937/1995, p. 11).

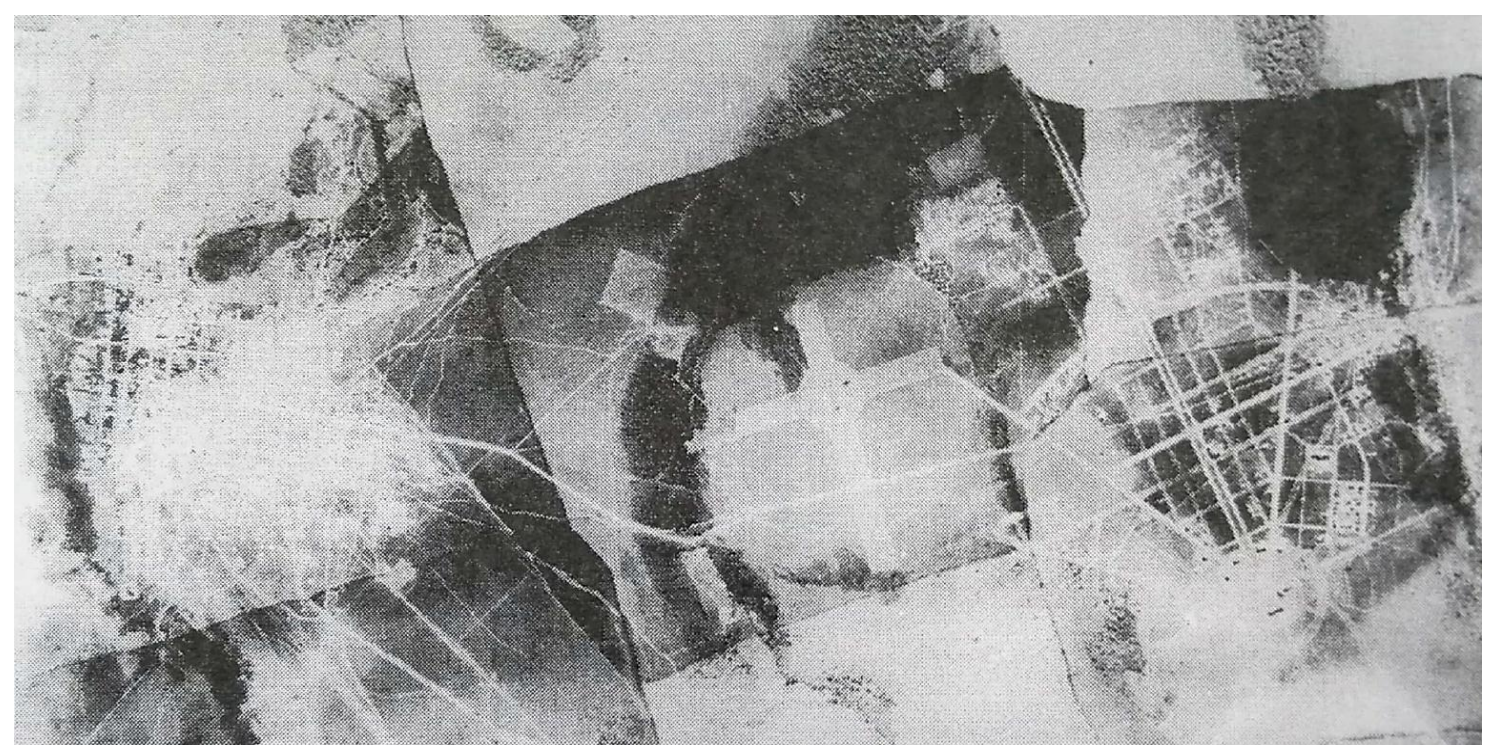

Figura 15: Levantamento aéreo de 1937. Escola de Aviação Militar. Fonte: Neto (1937/1995)/Acervo do MIS/GO. 
Os levantamentos aerofotogramétricos seriam reproduzidos em outros meios com eventuais recortes que, se por um lado poderiam aumentar o nível de detalhes ou atender necessidades de diagramação de determinada publicação, por outro também não deixariam de excluir algumas áreas significativas - como o núcleo preexistente Campinas ou ocupações não previstas no plano original. Deve-se ressaltar, contudo, que a aerofotogrametria não se apresentaria como um elemento avulso, sendo combinada, por exemplo, com outras vistas também capturadas a partir de sobrevoos - que similarmente forneceriam uma perspectiva superior da nova capital, mas se distinguiriam pela obliquidade, o que permitiria uma melhor apreensão de seu tecido urbano. Assim, entre tomadas gerais e parciais, de acordo com os ângulos de captura se daria ênfase a aspectos como o traçado (ainda sem sinais de asfalto) e as massas edificadas que rapidamente surgiam no sítio.

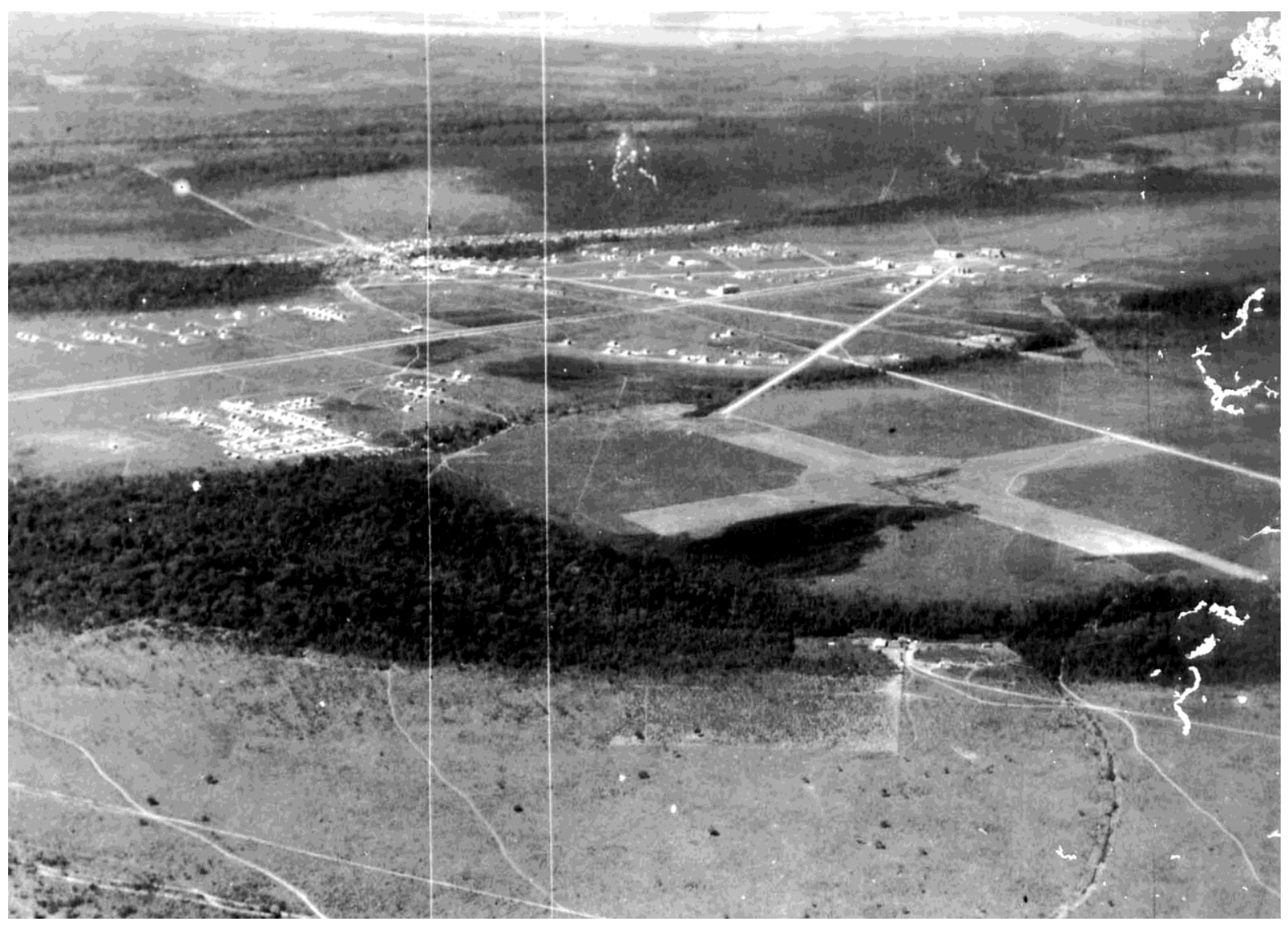

Figura 16: Goiânia em 1937. Escola de Aviação Militar/Antônio Pereira da Silva. Fonte: Acervo do CPDOCFGV.

Além de estamparem o Álbum de Fotografias sobre o Planejamento e Construção da Cidade de Goiânia, as imagens de sobrevoo também permeariam o Álbum de Goiaz e praticamente todas as obras historiográficas pioneiras. Ademais, ainda pôde-se mapeá-las em acervos como do ex-ministro da Educação e Saúde Gustavo Capanema - atualmente depositado nos arquivos do Centro de Pesquisa e Documentação da Fundação Getúlio Vargas 
-, como amostra das realizações da interventoria e do governo central no pós-1930 23 . Não se trata, porém, de um olhar apenas mediado pelas lentes das câmeras: sem deixar de lembrar as perspectivas da Firma Coimbra Bueno, convém destacar que a vista em vol d'oiseau seria o primeiro contato de diversos viajantes que chegariam à nova capital de avião. Pierre Monbeig (1938/1942, p. 76), por exemplo, registraria sua surpresa ao sobrevoar o sertão e se deparar com uma urbe que crescia "com o vigor de uma nova e robusta planta em um ambiente de aparência hostil".

Uma última hora de voo, a mais de 2500 metros, nos faz ver uma parte do Estado de Goiaz, onde as habitações se tornam cada vez mais raras e as roças cada vez mais minúsculas. O cerrado permanece mais inteiro que no Triângulo Mineiro, mais espesso e também mais elevado. Essa terra pôde antigamente conhecer uma atividade humana mais intensa na época da mineração; mas, será a terra do futuro? O viajante é bem tentado a acreditá-lo, quando, com uma celeridade brutal, em pleno meio do sertão, a uns 60 quilômetros da via férrea, se erguem os modernos edifícios de Goiânia. Estupefação de descobrir, enquanto o piloto inicia uma hábil descida do seu pesado aparelho, construções ousadamente modernas! (MONBEIG, 1938/1942, p. 71-72)

Impressão similar seria registrada por Cristóvão Leite de Castro, secretário-geral do Conselho Nacional de Geografia.

Viajar-se no meio de extensa vegetação, para, depois de horas e horas de reflexo de paisagens verdes, e só verdes, encontrar-se um núcleo urbano, moderno, planejado, cheio de habitações, de movimento e de vida, em que se respira a ânsia do progresso, é qualquer cousa de surpreendente e constitui uma afirmação expressiva, afirmação de vontade e de confiança, pelo que se realiza hoje na visão do futuro. Viajando-se de avião, a miragem de Goiânia longínqua, envolta numa extensa massa vegetal circundante, é uma surpresa que conduz à meditação profunda da vontade humana a impor-se no quadro colossal da natureza imensa. (CASTRO, 1942/1942, p. 113-114)

Todavia, tais visões, fruto de uma perspectiva própria, não seriam necessariamente compartilhadas por muitos daqueles que se dirigiriam a Goiânia de outros modos. Paulo Augusto de Figueiredo, um dos organizadores da Revista Oeste, rememoraria sua chegada à nova capital nos fins da década de 1930 - mas com uma leitura bem distinta do geógrafo francês.

\footnotetext{
23 No arquivo de Gustavo Capanema, há um expressivo acervo documental referente a Goiânia, dentre manuscritos e peças gráficas como plantas, perspectivas e fotografias - muitas das quais presentes também no material de referência desta dissertação, dada a circulação das imagens. A origem deste acervo em específico remeteria, pelo menos em parte, a um levantamento empreendido por Capanema nos fins da década de 1930, com o intuito de organizar um livro-documentário em comemoração ao primeiro decênio do governo de Getúlio Vargas. O livro, que se chamaria Obra Getuliana, não chegou a ser publicado, mas mobilizou numerosos agentes como os fotógrafos alemães Eric Hess, Erwin von Dessauer, Peter Lange e Paul Stille - a este último, inclusive, se atribuiriam algumas das tomadas aéreas de Goiânia, embora se ressalte que grande parte das fotografias da nova capital adviria de fotógrafos de atuação local, como Alois Feichtenberger e Antônio Pereira da Silva. Para mais informações sobre a Obra Getuliana, verificar trabalhos como de Lacerda (1994) e Cavalcanti (2006).
} 
Cheguei a Goiânia, à noite, em princípio de 1938. De Uberaba, íamos de trem até Leopoldo de Bulhões, com baldeação e pernoite em Araguari. De Leopoldo de Bulhões a Goiânia, a viagem era de carro, em estrada (por sinal boa) de terra. Nessa curta viagem, impressionou-me a quantidade de emas e seriemas que vi pelas planícies marginais da estrada. O carro já tinha passado por Goiânia, estava em Campinas, quando perguntei ao motorista:

-Falta muito para chegar a Goiânia?

- Já passamos, estamos em Campinas.

"Puxa - disse comigo mesmo - onde é que vim parar! Então é isso que é Goiânia (algumas ruas, alguns palácios, o resto...um deserto)?” (FIGUEIREDO, P. A. apud TELES, 1986/2012, p. 205)

O mesmo Paulo Augusto de Figueiredo, não obstante, reconheceria que Goiânia iria além de suas feições iniciais e dispunha-se, sobretudo, como um símbolo. Daí derivaria a célebre expressão "Goiânia não é coisa para ser vista; é coisa para ser compreendida" (FIGUEIREDO, P. A., 1943, p. 2), presente em um de seus artigos que exultariam o empreendimento da nova capital - e, consonantemente à linha editorial da Revista Oeste, o ideário estadonovista.

Encarada a cidade "em si", não se perceberá muito claramente o seu lugar nos quadros dos valores nacionais. Goiânia - repitamos ainda - vista "objetivamente", não é mais do que uma cidade como outra qualquer. Mas como realização, é algo que está além e acima de qualquer cidade brasileira. [...] Goiânia é como que a própria expressão, em termos urbanísticos, do Brasil Novo, do Brasil que se redescobriu, do Brasil unificado num só corpo e num só espírito, do Brasil que coordenou todas as nossas forças, orientando-as para fins altos e nobres, do Brasil que se ergueu do "berço esplêndido" e começou, já, a cavalgada da glória. [...] Goiânia é, assim, espécie de cadinho, em que se cozem e purificam os nossos vários caracteres. Nela, mais do que em outro ponto qualquer, se encontram os dois Brasil - o do litoral e o do sertão -, nela se está formando a célula do Brasil integral. (FIGUEIREDO, P. A., 1943, p. 2-3)

Gerson Castro Costa apontaria exatamente a mesma lógica. Em que pese o choque inicial ao verificar em Goiânia "um vazio informe, [...] quase um panorama lunar, inexplicável aos olhos inexperientes do observador" (COSTA, G. C. apud GOIÂNIA, 1985, p. 95), Castro Costa contemporizaria o cenário de uma cidade em construção igualmente atribuindo-lhe um sentido ideológico. O progresso pareceria independer de um estágio de consolidação plena e, naquele quadro, se arrimaria especialmente na iniciativa de sua realização - e na promessa de um faustoso futuro.

Efetivamente, é uma obra filha do esforço e do labor locais, é uma realização que não foi sequer buscar a inspiração de sua origem nos centros de alta densidade demográfica do litoral, como sói suceder histórica e tradicionalmente na interiorização territorial das Américas. Saiu de si própria, de pleno núcleo geográfico do País, num desassombro vigoroso que bem atesta a potencialidade civilizadora do povo brasileiro. [...] Goiânia é de fato senhora, no porvir, de um dos mais belos destinos das cidades brasileiras. (COSTA, G. C., 1942, p. 3-4)

Sem adentrar em possíveis paradoxos - uma vez que a ideia de uma cidade nascida de si própria poderia conflitar, por exemplo, com as filiações urbanísticas de Goiânia, tão 
evocadas pela mesma vertente discursiva -, se é possível identificar uma tônica comum nos discursos de Paulo Augusto de Figueiredo e Gerson Castro Costa, permeada por uma semântica traduzida em termos como "nacionalidade" e "obra", não deixemos de assinalar a atuação concomitante das imagens da Revista Oeste na sedimentação dessas mensagens. Seguindo o nexo de uma construção cultural que buscava romper com as representações de decadência e atraso, várias das fotografias dispostas ao longo de suas 23 edições operariam no sentido de salientar um Goiás pujante - visualmente traduzido através de obras de infraestrutura, como ferrovias e pontes, ou mesmo boiadas -, ao mesmo tempo que a "menina dos olhos" ludoviquista, Goiânia, apareceria abundantemente representada sobretudo a partir de vistas urbanas. No que tange especificamente à cidade-obra, destaca-se uma peça gráfica reproduzida em diversas edições da revista, cuja composição se estruturaria a partir de duas fotografias da nova capital atreladas às figuras de Pedro Ludovico e Getúlio Vargas, com os dizeres "Goiânia assinala o profundo realismo da Marcha para o Oeste" e "Uma obra gigantesca de brasilidade que recomenda à gratidão da pátria o nome do grande brasileiro Pedro Ludovico Teixeira”.

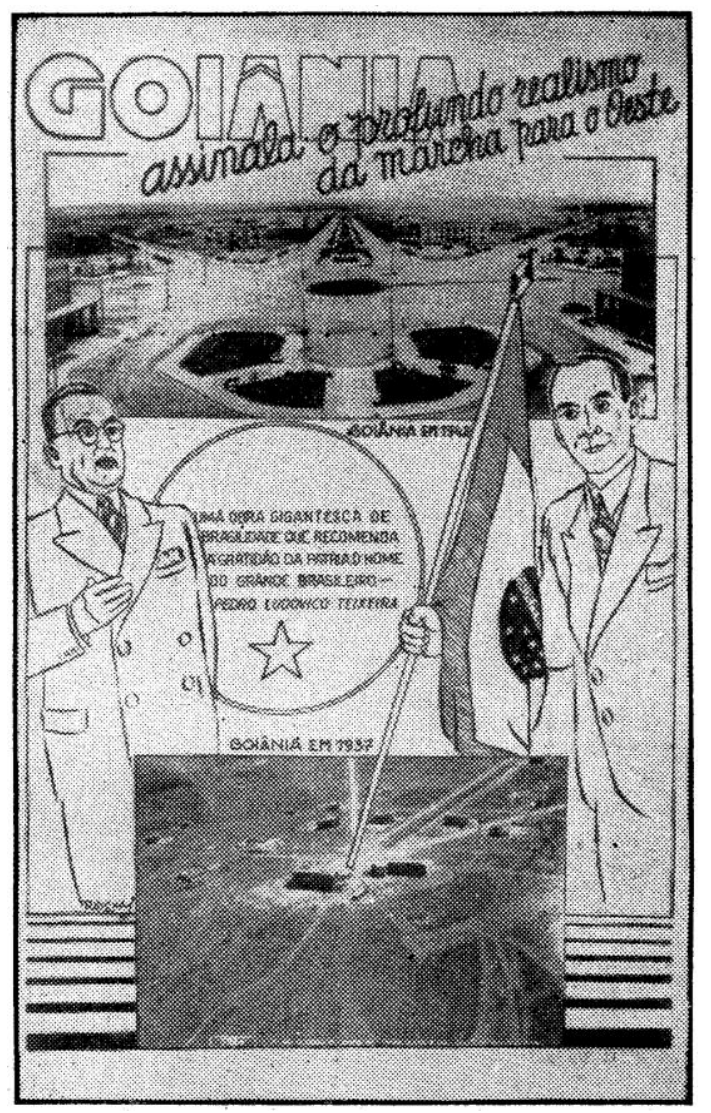

Figura 17: Pôster de Goiânia. Autoria desconhecida (fotografia acima) e Escola de Aviação Militar/Antônio Pereira da Silva (fotografia abaixo). Fonte: Revista Oeste (1944) 
As duas capturas presentes na peça gráfica dizem respeito ao Centro Cívico da nova capital em momentos distintos. Na fotografia disposta na porção inferior, vê-se o cerne do novo núcleo a partir de um sobrevoo realizado em meados de 1937, onde é possível identificar ao centro da imagem, próximos entre si, o Palácio do Governo e a Secretaria Geral do Estado, edifícios que já se encontrariam entregues e ocupados, embora ainda se verificassem provisórias estruturas de obras nas suas imediações. Contíguos às vias radiais, se disporiam outros edifícios que abrigariam órgãos federais, como a sede da Delegacia Fiscal e o Juízo Eleitoral. As obras seguiam com velocidade, mas os blocos soltos numa campina recortada por esboços de via ainda remeteriam mais ao cenário lunar evocado por Castro Costa que à nobreza do centro de uma nova capital. Em contrapartida, se apreenderia um quadro distinto na fotografia da porção superior, datada em 1942 - e ressalta-se a indicação da data na legenda como artifício para mensurar o ritmo da construção: contemporâneo ao Batismo Cultural de Goiânia, o registro a partir do topo do Palácio do Governo já sugeriria um núcleo consolidado, com numerosos edifícios, rede elétrica e um cuidadoso tratamento paisagístico com jardins baixos, passeios públicos e tenras árvores dispostas de forma ritmada.

Essa lógica comparativa baseada no uso de duas ou mais imagens para revelar o intenso desenvolvimento da cidade, aliás, seria comum. Numa matéria comemorativa ao nono aniversário de Goiânia, publicada no $O$ Popular (jornal que, lembremo-nos, fora fundado e dirigido, entre outros, por Joaquim Câmara Filho, o insigne diretor do Departamento de Propaganda e Expansão Econômica do Estado), a perspectiva do Centro Cívico confeccionada pela Firma Coimbra Bueno se apresentaria como a idealização, ao passo que a fotografia de 1942 - a mesma empregada na Revista Oeste - se mostraria como a realização. O jogo de figuras, colocadas lado a lado, sintetizaria o conteúdo da reportagem, que listaria uma série de feitos empreendidos num curto espaço temporal, capaz de surpreender até mesmo os mais otimistas (9ªNIVERSÁRIO..., 1942, p. 1).

[...] serviço de esgoto, asfaltamento, construção de magníficos prédios, modernas avenidas, perfeita rede d'água, o melhor cinema do interior do Brasil, telefone automático, serviço de urbanização da cidade, inúmeros e importantes prédios públicos, piscinas e lagos artificiais, praças e jardins obedecendo aos mais modernos requisitos de estética, serviço de assistência social, residências para funcionários públicos, estabelecimento de ensino nos moldes determinados pela pedagogia hodierna, e uma série de outras concretizações, também dignas de registro [...] $\left(9^{\circ}\right.$ ANIVERSÁRIO..., 1942, p. 1) 


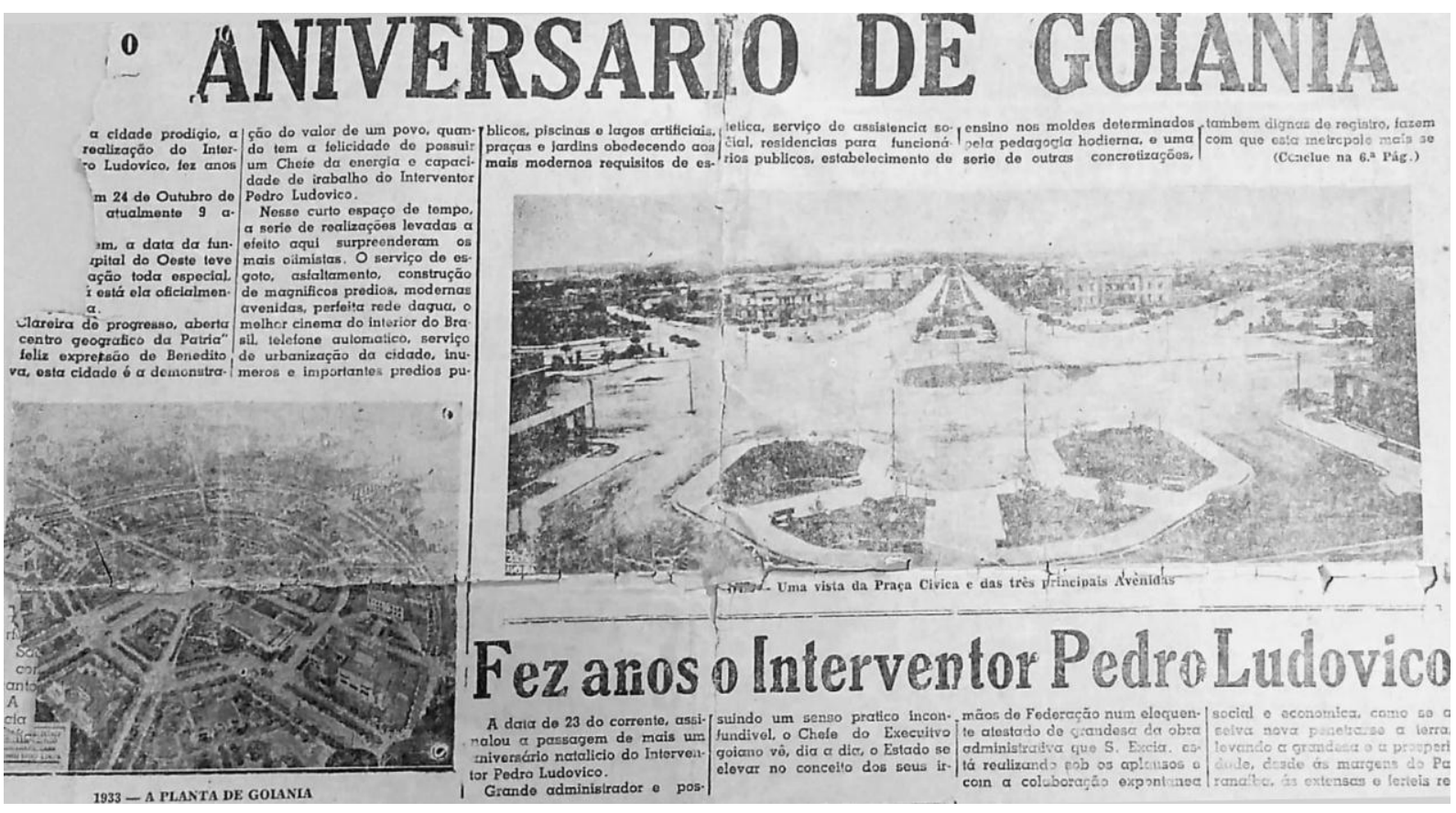

Figura 18: Reportagem sobre o $9^{\circ}$ aniversário de Goiânia. Firma Coimbra Bueno \& Cia Ltda. (fotografia à esquerda) e autoria desconhecida (fotografia à direita). Fonte: O Popular (1942)/Acervo do AHEG.

Outro exemplo encontra-se no livro de Ofélia Monteiro (1938), em seu subcapítulo intitulado "III Fase, Construção", onde se percebe a sequência de três imagens do Palácio do Governo - conquanto não necessariamente imediatas entre si. A primeira das fotografias (figura 19) apresentaria o edifício em construção, com a etapa de alvenarias finalizada; já na segunda (figura 20), numa ocasião não muito posterior à primeira fotografia, se indicaria o início dos trabalhos de pintura; enquanto na última (figura 21) o edifício aparentemente já se encontraria concluído, mas ainda sem esboçar tratamento urbanístico em seu entorno - uma vez que a publicação de Ofélia Monteiro (1938) antecederia o término dos trabalhos na região do Centro Cívico.

Pelo estágio da obra ${ }^{24}$, os registros possivelmente corresponderiam ao período entre os anos de 1935 e 1937 - momento em que a Firma P. Antunes Ribeiro e Cia, empresa que o arquiteto Paulo Antunes Ribeiro outorgaria ao amigo Attilio para celebração dos contratos com o Estado de Goiás, já não era mais responsável pelos serviços de construção. Isso significa que a execução de razoável parcela da obra ocorreria sem o acompanhamento do autor de seu projeto arquitetônico original, colocando os irmãos Coimbra Bueno como

\footnotetext{
${ }^{24}$ Num relatório da Firma Coimbra Bueno, há a informação que, nos fins de 1934, se encontrariam "prontas as fundações, levantadas as paredes do primeiro e do segundo pavimentos e concretadas as lajes, de impermeabilização, e do $2^{\circ}$ piso" (COIMBRA BUENO \& CIA LTDA., 1936 apud MONTEIRO, O. S. N., 1938, p. 467). De acordo com o mesmo relatório, em março de 1936 a obra se encontraria em estágio avançado, com revestimento interno e externo, cobertura e instalação de esquadrias já concluídos. A informação é corroborada por outras fotografias, além de um trecho do relatório de Attilio Corrêa Lima recuperado por Diniz (2007). O documento, datado no início de 1935 e contemporâneo ao afastamento de Attilio das obras, apontaria que o Palácio detinha revestimento externo.
} 
empreendedores (ou pelo menos mediadores) de algumas das decisões projetuais. Esses meandros sutilmente apareceriam na sequência fotográfica.

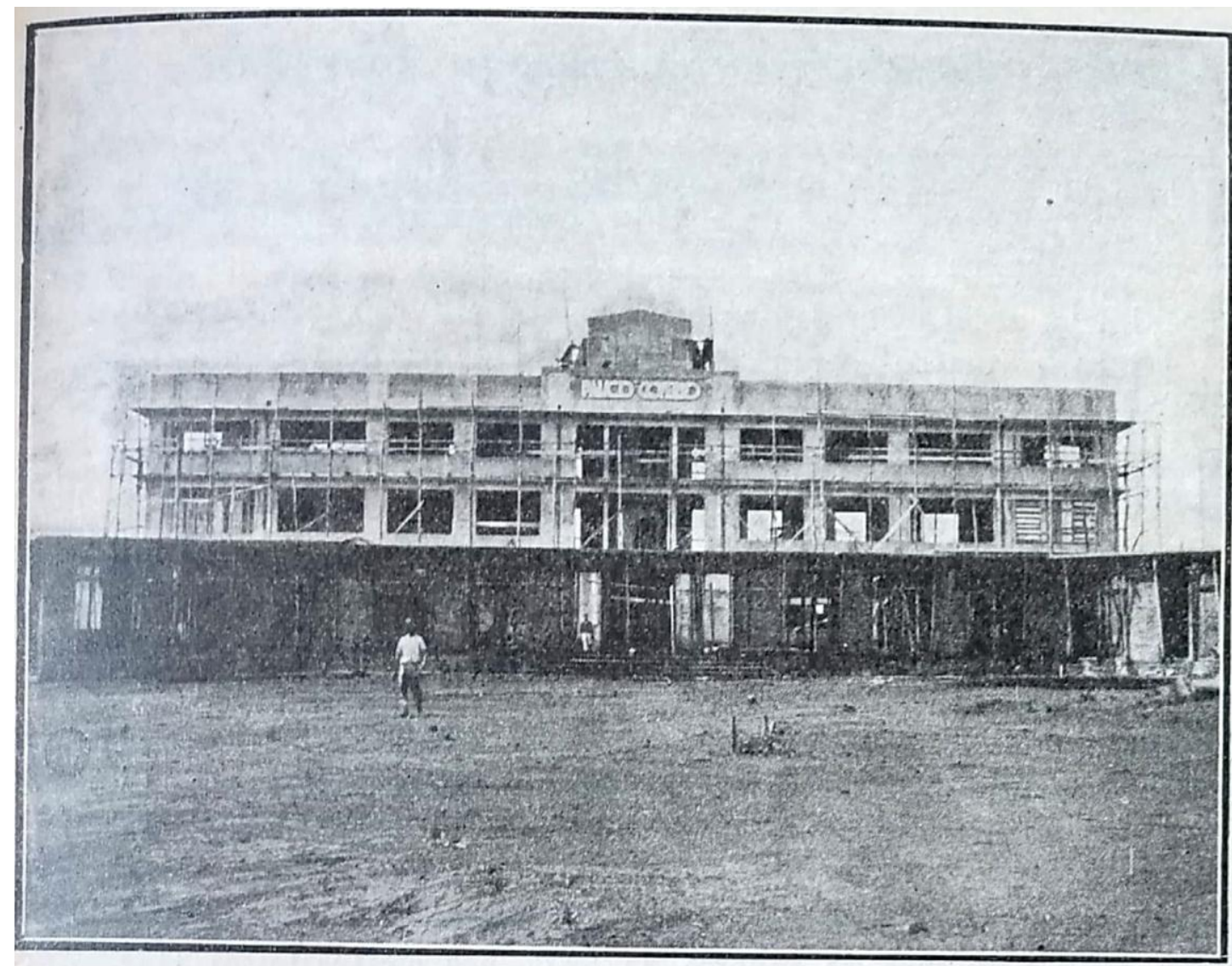

Figura 19: "Palácio do Governo, em construção". Legenda da publicação. Autoria desconhecida. Fonte: O. S. N. Monteiro (1938).

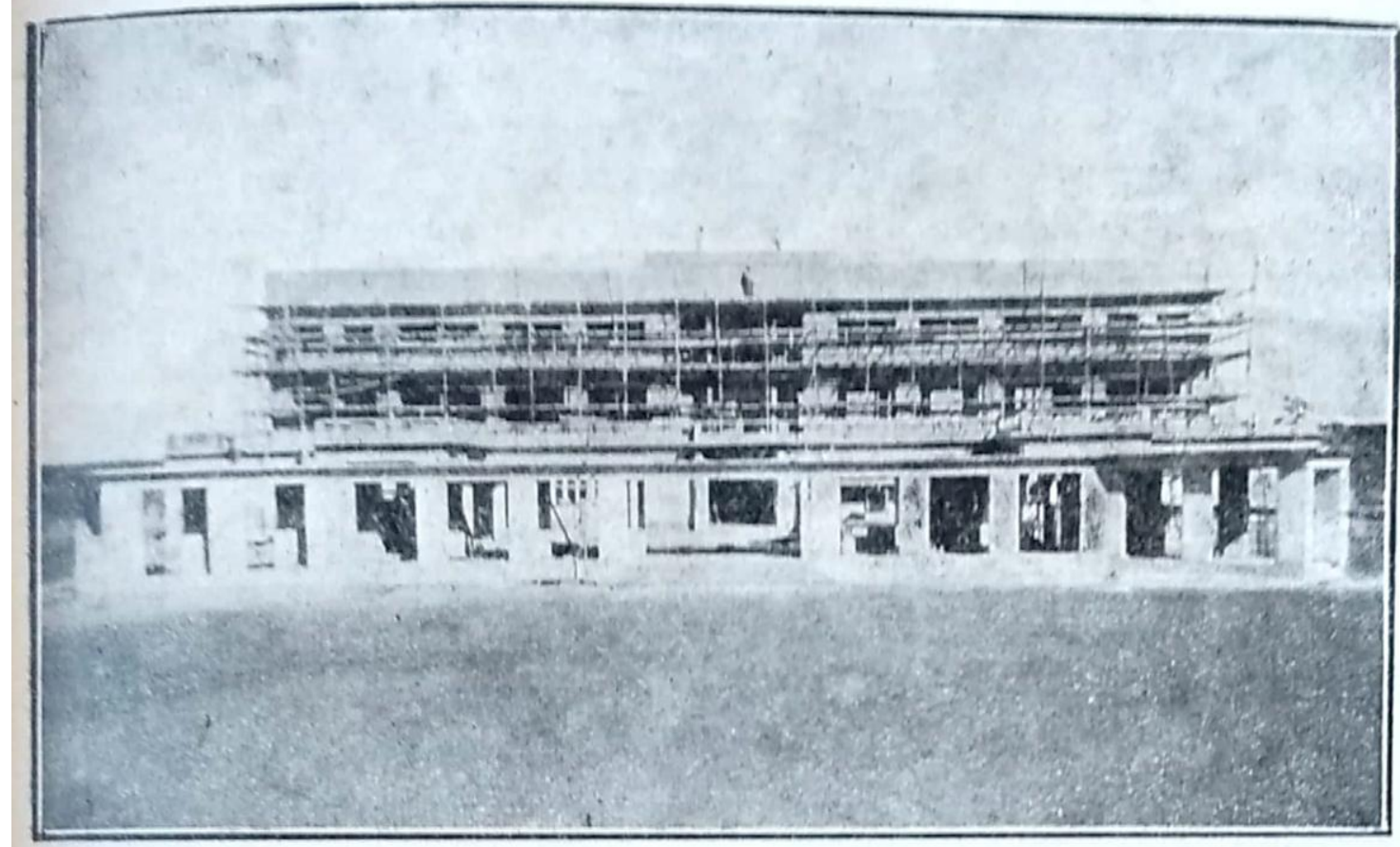

Figura 20: "Palácio do Governo (ao se iniciar a pintura externa)". Legenda da publicação. Autoria desconhecida. Fonte: O. S. N. Monteiro (1938). 


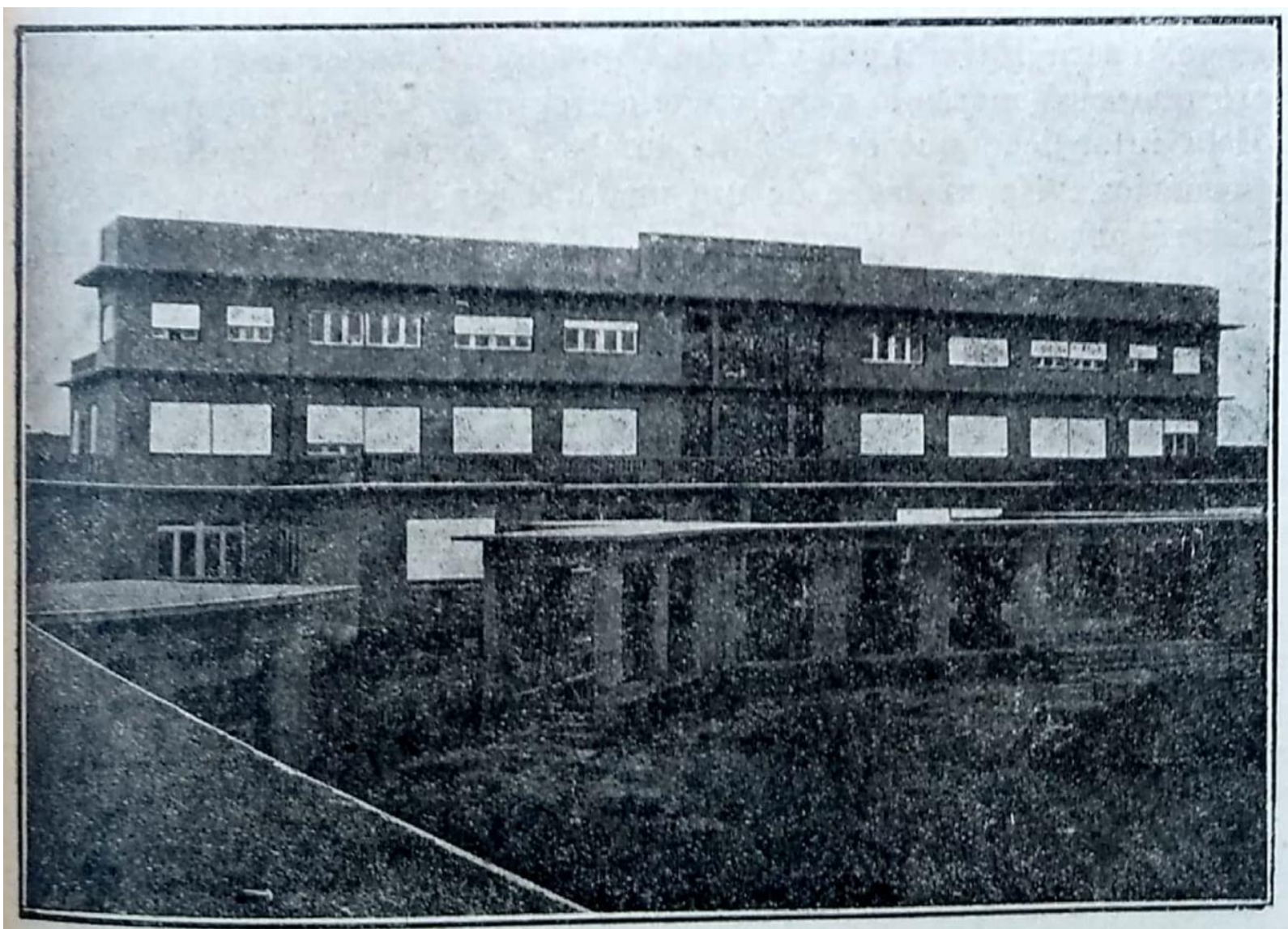

Figura 21: "Palácio do Governo, em Goiânia". Legenda da publicação. Autoria desconhecida. Fonte: O. S. N. Monteiro (1938).

Além de alterações no dimensionamento das aberturas, chama atenção a presença da inscrição "Palácio do Governo" na primeira imagem - e apenas nela -, como indício de retrabalho em meio a decisões concomitantes à obra. O detalhe (ou sua ausência) não passaria despercebido por Eurico de Godoi - expressivo arquiteto goiano formado pela Faculdade Nacional de Arquitetura da Universidade do Brasil -, que rememoraria seu olhar de criança naquele princípio de cidade.

Numa dessas vindas a Goiânia, o Palácio do Governo já estava em fase de acabamento e fiquei encantado com um enorme letreiro feito da própria massa vermelha da fachada, na parte mais alta do prédio, isto é, na platibanda. O nome era PALÁCIO DO GOVERNO e tinha mais ou menos 1 metro de altura por uns 15 ou 20 metros de comprimento. Logo que voltei à minha escolinha, contei ao meu professor o fato. Ele simplesmente não aprovou, achou que deveria ser uma placa de bronze, pequena e discreta, para identificar o prédio público. Fiquei pensativo com aquela reação, não sabia quem tinha razão, se aquele professorzinho, bem dizer da roça, ou os construtores e arquitetos do Palácio. Dias depois, voltando à obra, qual não foi minha surpresa, ao ver os operários desmanchando (raspando a massa) todo aquele grande letreiro. Não é que o meu professorzinho, lá de Campininha, tinha razão? (GODOI apud GOIÂNIA, 1985, p. 232)

Analogamente, outro elemento que deixaria de existir durante a construção é o volume central na cobertura da edificação, modificando seu coroamento inicial. Não foi possível levantar o projeto original do Palácio do Governo, embora seja perceptível, em 
croquis do Centro Cívico elaborados por Corrêa Lima, um volume similar num ainda esquemático edifício. Segundo escassas informações colhidas na Secretaria Municipal de Planejamento Urbano e Habitação de Goiânia, o volume aparentemente seria uma espécie de cúpula, onde se disporiam areias de Goiás. De qualquer modo, independentemente de sua finalidade, a demolição do elemento evidencia revisões arquitetônicas permeadas por múltiplos agentes - como é possível verificar em outro tópico do relatório encaminhado pela Firma Coimbra Bueno ao Diretor Geral da Fazenda em 1936 -, e onde a eventual falta de consenso ou tempo hábil para definição de questões poderiam acarretar na supressão ou modificação de detalhes.

Aproveitamos a oportunidade para chamar a atenção de V. Excia. para ser modificado o brasão do Estado para um mais simples e moderno, fácil de ser memorizado e se possível em tempo de ser esculpido no painel, acima da fachada da frente do Palácio, que reservamos para este fim, e que seria de toda conveniência ser esculpido antes da terminação das obras. Deixamos de esculpir o atual brasão em vista da impossibilidade de o fazer, por ser demasiadamente complicado. (COIMBRA BUENO \& CIA LTDA., 1936 apud MONTEIRO, O. S. N., 1938, p. 468)

Outro caso que ajuda a compreender as dinâmicas de obra diz respeito ao Grande Hotel. Por motivos que iriam da mudança da administração de obras a limitações construtivas, percebem-se diferenças substanciais entre a concepção inicial ${ }^{25}$ e o edifício no momento de sua inauguração, sobretudo mediante modificações nas fachadas - como padrão das esquadrias e proporções de volumes - e adoção de soluções técnicas distintas - como a substituição da cobertura em laje impermeabilizada por telha cerâmica escondida pela platibanda, à semelhança da residência de Warchavchik na Rua Santa Cruz, conforme lembraria Diniz (2007). Outrossim, em que pese a idealização projetual sem nenhum letreiro, a inscrição "Grande Hotel” seria similarmente executada (e, nesse caso, mantida) na fachada voltada para a Avenida Goiás. Adolfo Boari, que trabalhara nesta obra juntamente com seu pai, revelaria alguns dos percalços durante a construção.

- [...] Meu pai deu uma errada danada lá. Ele deixou a planta e fez um serviço muito mais caro. Perdeu dinheiro lá. Desmancharam o que ele fez. Ele fez uma escada de serviço que não tinha. Eu briguei com meu pai. Saí de lá sem falar com ele. Ele atravessou uma viga que a pessoa tinha que abaixar para passar.

- Mas, se seu pai fazia estas modificações na planta original, não havia ninguém contra?

- Tinha o Dr. Eurico Viana que entregava e deixava ficar; [...] (BOARI apud GOIÂNIA, 1985, p. 18)

Em que pesem os contratempos e as acomodações, as obras trariam consigo a aura do progresso não apenas pela concretização dos desígnios ou pelos traços dito modernos das

${ }^{25}$ O projeto original pode ser encontrado na obra de Diniz (2007). 
edificações, mas também pelo emprego de técnicas construtivas ainda pouco difundidas na região, sobretudo com a utilização do concreto armado. As feições das construções, com estruturas concebidas para abrigar múltiplos pavimentos, também impressionariam o ainda menino Eurico de Godoi.

Dias após nossa chegada, fomos fazer uma visita a única obra iniciada na cidade, os alicerces do Palácio do Governo. Eu, ainda muito menino, fiquei assustado de ver o tamanho dos buracos destinados às fundações que iriam suportar o grande edifício. Nunca tinha visto uma construção com mais de dois pavimentos. Até hoje penso que os buracos eram realmente enormes, calculo um metro de largura por um metro de altura; era o que hoje chamamos de alicerce corrido de pedra marroada. (GODOI apud GOIÂNIA, 1985, p. 232)

Não se pode deixar de mencionar o relevante papel de Attilio Corrêa Lima na adoção de determinadas soluções construtivas, tanto por sua concepção arquitetônica quanto pela atuação nas primeiras etapas da construção da nova capital. As obras de Goiânia seriam marcadas por um profissional ainda em transição, principalmente diante de sua formação e das especificidades locais, mas sabe-se que Attilio estava atento a inovações construtivas como a pré-fabricação e a racionalização da arquitetura. Em cartas enviadas aos seus pais na época que residia na França ${ }^{26}$, Corrêa Lima mencionaria realizações de Le Corbusier e Walter Gropius, além de citar um colega de curso, Berthold Lubetkin - egresso do Vkhutemas que, com sua expressiva bagagem técnica, ministraria um curso de concreto armado para Attilio, Paulo Antunes Ribeiro e outros colegas do Institut d'Urbanisme de l'Université de Paris (DINIZ, 2017).

Attilio Corrêa Lima, contudo, se mostraria ciente das dificuldades de empregar determinadas técnicas diante do cenário que se vislumbrava na construção civil nacional e regional. Numa de suas cartas como estudante, o urbanista indicaria estar pensando sobre a possibilidade de criar "uma escola profissional para formar operários especializados na construção, especialmente em cimento armado" (LIMA, A. C., 1929 apud DINIZ, 2017, p. 254). Posteriormente, após atuar em Goiânia, se relembraria das dificuldades de se erguer uma cidade em pleno sertão sem deixar de mencionar o "problema da mão de obra deficiente, não adaptada aos métodos modernos de construir" (GOIÂNIA..., 1942, p. 3) - e, não por acaso, constaria no contrato de administração da obra do Palácio do Governo o traslado de uma equipe de mestre e operários do Rio de Janeiro para a execução da estrutura da edificação.

\footnotetext{
${ }^{26}$ Ver a publicação O itinerário pioneiro do urbanista Attilio Corrêa Lima, de Anamaria Diniz (2017). O segundo volume da obra traz 58 cartas fac-símiles de Attilio, digitalizadas e organizadas cronologicamente.
} 
Postura similar seria adotada pelos irmãos Coimbra Bueno que, conquanto tenham assumido obras em andamento, também contribuiriam substancialmente para desenvolvimento técnico das construções da nova capital. Os engenheiros Jerônimo e Aberlado, por exemplo, igualmente estariam a par do concreto armado, uma vez que se registra a abordagem do tema na Escola Politécnica do Rio de Janeiro - da qual são egressos pelo menos desde 1914 (FREITAS, M. Z., 2011). Concomitantemente, os irmãos contratariam diversos profissionais de currículos destacados, como os engenheiros Gustav Aderup - que trabalhara nos cálculos da estrada de rodagem Rio-Petrópolis, a primeira rodovia asfaltada do país - e Jorge Diniz Carneiro - que antes atuara na Construtora Pederneiras S/A e, posteriormente, chegaria a assumir a Secretaria de Viação e Obras da Prefeitura do Rio de Janeiro. A expertise da equipe técnica subsidiaria iniciativas como o redimensionamento da última laje do edifício da Secretaria Geral, também originalmente concebido por Corrêa Lima, de modo que haveria capacidade "para receber mais um andar, em época em que isto se fizer necessário" (COIMBRA BUENTO \& CIA LTDA., 1936 apud MONTEIRO, O. S. N., 1938, p. 469) - o que acabou não acontecendo.

Outrossim, os irmãos ainda recrutariam mão de obra especializada para a execução do acabamento das edificações: os pintores seriam os mesmos encarregados pela pintura do Palácio dos Campos Elísios, de São Paulo; os estucadores teriam atuado no revestimento do Edifício Rex, no Rio de Janeiro; e os mestres de obra adviriam da reforma do Teatro Municipal e da construção do edifício do Ministério da Viação, também na capital federal. O rigor com a qualidade dos serviços se arrimaria na retórica do progresso, onde as construções seriam imbuídas de um valor educativo ao adotarem acabamentos parelhos aos edifícios de centros como São Paulo e Rio de Janeiro.

[...] estas obras são as primeiras aqui edificadas, elas têm, portanto uma função altamente educativa. Elas representam os marcos de um avanço que a administração atual vai dando à civilização do Estado e, portanto, devem ser colocadas no ponto mais próximo possível dos fins colimados: a sincronização de nosso progresso com o dos centros mais avançados do Brasil; e assim, impressionar bem fundo o espírito de nossa gente para fazê-las sentir com a evidência dos fatos o quanto nós estamos atrasados em relação àqueles centros, e com argumento insofismável das cousas feitas, convencê-los que este avanço que se tenta é realizável. Esta função psicológica, profundamente educativa, que estas obras necessariamente têm que cumprir, têm sido o motivo de nosso zelo em dar-lhe um acabamento o quanto possível perfeito. (COIMBRA BUENO \& CIA LTDA., 1936 apud MONTEIRO, O. S. N., 1938, p. 473)

O caráter pedagógico transparecia pela função modelar das edificações pioneiras, uma vez que estas se disporiam como exemplo para as construções subsequentes, mas não somente isso: propagava-se que "as obras de Goiânia serviram de escola e aprendizado ao 
brasileiro do Oeste" (ALVARES, 1942, p. 178), conforme informaria a legenda de outra fotografia do Palácio do Governo ainda em construção - e que, diferentemente das imagens publicadas na obra de Ofélia Monteiro (1938), apareceria tomado por operários que, sob o obliquo sol do final de expediente, posavam para o registro.

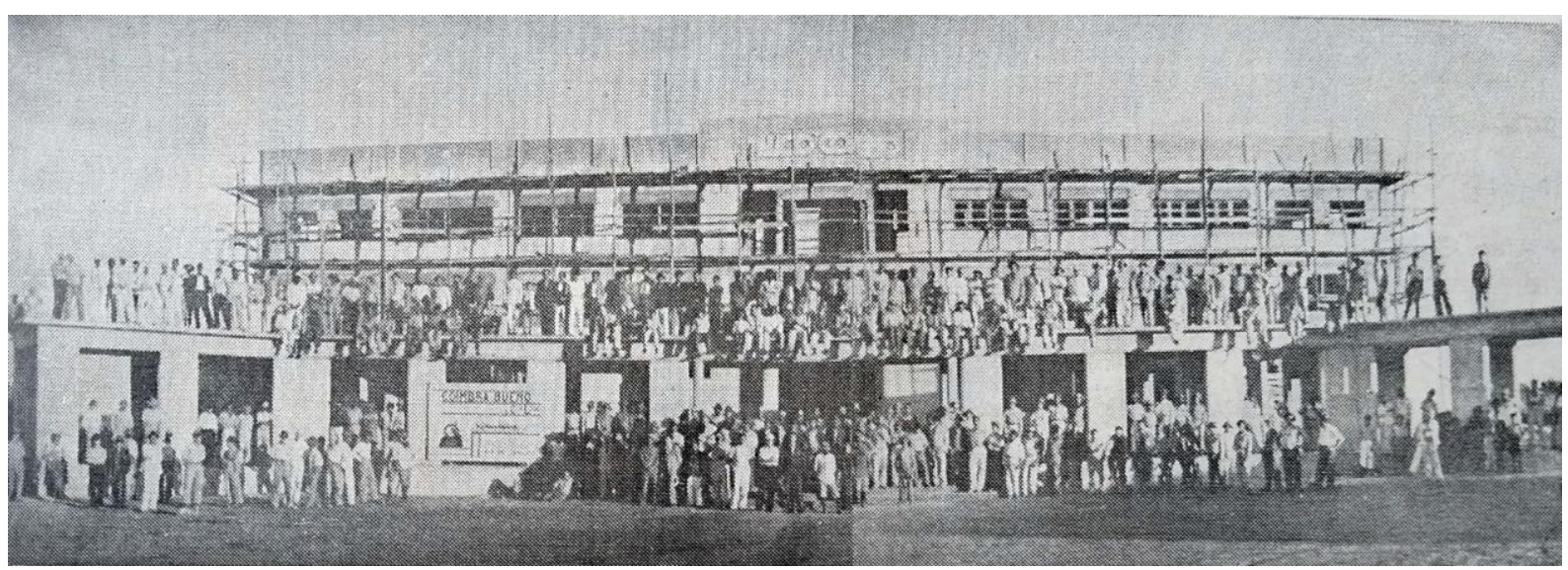

Figura 22: Operários no Palácio do Governo. Autoria desconhecida. Fonte: Alvares (1942).

A materialização da cidade, diversas vezes definida como uma colmeia de trabalho, se daria, portanto, a partir do empenho dos homens da política e do saber técnico, mas também pelas mãos dos trabalhadores braçais, frequentemente ignotos, em numerosas frentes de serviço. O progresso igualmente seria, pois, filho do árduo labor, das longas jornadas e dos mutirões, outros aspectos da cidade-obra.

\subsection{A construção e as imagens do labor}

Com o chegar da tarde eis que chegam também / os operários da cidade, artistas verdadeiros / sempre escondidos sob o manto do anonimato. / E a gente vê, provocando os céus, / desafiando vendavais e furacões / esses colossos de cimento armado... / Vê, e fica pensando num corpo recurvado de cansaço, / nuns pobres olhos castigados pela inclemência do sol / e nas mãos calejadas e nodosas que plasmaram o cimento, / tirando da massa bruta toda essa maravilha que hoje forma a cidade. (FLEURY, 1944, p. 32)

O cotidiano da cidade que se erguia na campina, a princípio, seria impregnado pela azáfama das obras. "Aqui só se falava em trabalho. Goiânia era uma verdadeira oficina, uma grande oficina em construção, pouca diversão", afirmaria o pioneiro Hilarino Veloso da Silveira (apud GOIÂNIA, 1985, p. 110), ex-funcionário da Superintendência de Obras, num nexo que não deixaria de ser constantemente evocado com matizes ufanistas em discursos que permeariam a construção da nova capital. Numa reportagem da Folha de Goiaz intitulada "Goiânia, oficina de trabalho no oeste brasileiro", exaltava-se que, logo após o término das festividades do segundo aniversário de sua inauguração oficial, tudo na nova capital voltaria à costumeira rotina na qual os "trabalhadores de rua, operários, colegiais e servidores anônimos do progresso local atravessam as avenidas na faina de sua labuta diária [...] no seu 
interminável labor de construções, negócios e divertimento de toda a espécie”. (GOIÂNIA..., 1944). Similarmente, o então tenente-coronel José de Lima Figueiredo (1942, p. 3), um entusiasta da interiorização do país ${ }^{27}$, daria tons epopeicos à empreitada ao indicar que "depois de assentada a escolha do local, tudo se operou como se fosse a poder de mágica" por meio de mãos quase incansáveis.

Os operários nacionais e alienígenas não tinham tempo a perder. A golpes vivos de
energia levantam-se os andaimes e as máquinas iam movimentando a terra, afim de
aplicar ali os princípios clássicos que emprestaram encantos, dignos de nota por
qualquer visitante, a Washington e Versailles. A fada boa não descansava nem
deixava seus obreiros em folga e, enquanto não aprontava seu trabalho em Goiânia,
Campinas ia tomando acentuado incremento com a vinda de forasteiros atraídos pelo
faro de bons negócios. (FIGUEIREDO, J. L., 1942, p. 3)

Tendo como fio condutor as alusões ao labor, essa faceta da construção de Goiânia assim encontraria sua habitual representação sobretudo na figura do operário - aquele que, entre as visitas dos técnicos à região onde se implantaria o novo núcleo e os primeiros sinais do traçado que rapidamente se esboçaria no sítio, seria responsável por operar a quase mágica sinalizada por Lima Figueiredo. E, em que pese a menção ao maquinário, a transposição dos desígnios para o chão do cerrado se daria de maneira essencialmente manual: Pedro Ponchet Meireles, potiguar que atuara de servente de pedreiro a chefe de obras, revelaria que "para cortar a rua, era tudo feito na picareta e na pá. Não existia trator, existia aqui um compressor velho [...]" (MEIRELES apud GOIÂNIA, 1985, p. 148) que, embora chegasse a ser citado com certo furor em peças publicitárias (sugerindo uma ampla mecanização nas obras da cidade), não necessariamente corresponderia ao principal instrumento na realização de expressiva parcela das atividades.

O esforço braçal, destarte, reiteradamente apareceria nos registros de serviços preliminares. A abertura (e manutenção) de estradas, por exemplo, tão cara para a chegada de materiais de construção à nova capital - haja vista que, lembremo-nos, a estrada de ferro ainda não se encontrava diretamente interligada a Goiânia -, mobilizaria diversos trabalhadores que contariam basicamente com ferramentas manuais para regularizar o terreno, conforme evidenciaria a captura pelas lentes de Alois Feichtenberger. Num intrigante jogo de perspectiva que lhe é comum, o fotógrafo salientaria o contraste de personagens em primeiro plano e numa cota elevada - dentre eles, o primeiro prefeito de Goiânia, Venerando de Freitas

\footnotetext{
${ }^{27}$ Lima Figueiredo, militar que atuaria à frente de diversos órgãos do governo e ainda como deputado federal na década de 1950, seria autor de publicações e conferências como Limites do Brasil, Terras de Mato Grosso e Amazônia, Oeste paranaense e Getúlio Vargas e a conquista do sertão. Sob esse sentido, entusiasmado com a construção de Goiânia, Lima Figueiredo visitaria a cidade e sobre ela escreveria alguns artigos publicados em periódicos como Revista Oeste e Revista da Semana.
} 
Borges - com as diminutas figuras dos obreiros ao fundo, cujas feições pouco se revelariam sob as abas de seus chapéus, mesmo ao aproximar o olhar da imagem.

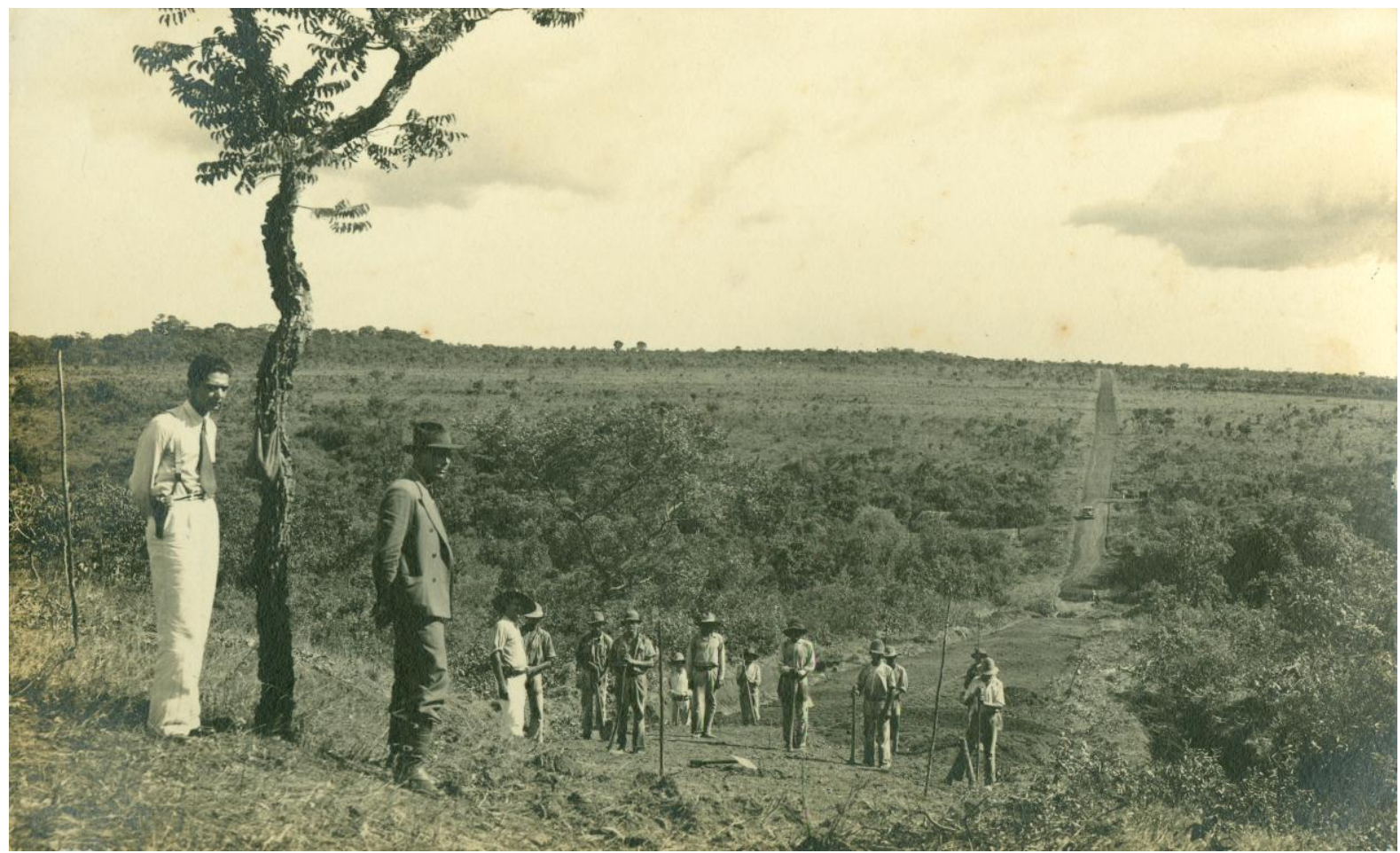

Figura 23: Venerando de Freitas Borges com trabalhadores em abertura de estrada, década de 1930. Alois Feichtenberger. Goiânia-GO. Acervo MIS/GO.

Outra fotografia, bastante célebre, diz respeito à limpeza do terreno onde se implantaria a nova capital. A imagem, datada em 1933 de acordo com os registros do Museu da Imagem e do Som de Goiás - conquanto a legenda na publicação de Alvares (1942) indique data posterior - registraria um grupo de homens, com vestimentas próprias para enfrentar o forte sol do Brasil Central, na roçagem da área que futuramente abrigaria o Centro Cívico da cidade - e onde, ao fundo, a planura da linha do horizonte seria rompida apenas pela vegetação na região do Bosque dos Buritis. Dante Ungarelli, outro pioneiro da cidade, relembraria a ocasião, na qual participaria sobretudo através de palavras de incentivo.

Goiânia nasceu sob o signo do mutirão. Nós fizemos mutirão para roçar a Praça Cívica, e eu estava lá, carregando água, não conseguimos ajuntar cem homens, mas tinha muito mais de cem para comer e beber, nunca deixou de ter os aproveitadores. Esse mutirão foi comandado por Licardino de Oliveira Ney, pelos Moraes e nós, os Ungarelli. Eu não rocei, eu carregava água e estimulava com palavras, dizendo que ia ser uma grande cidade, que estávamos roçando esse cerrado, que vai ser uma metrópole, uma cidade grande. (UNGARELLI apud TELES, 1986/2012, p. 79-80) 


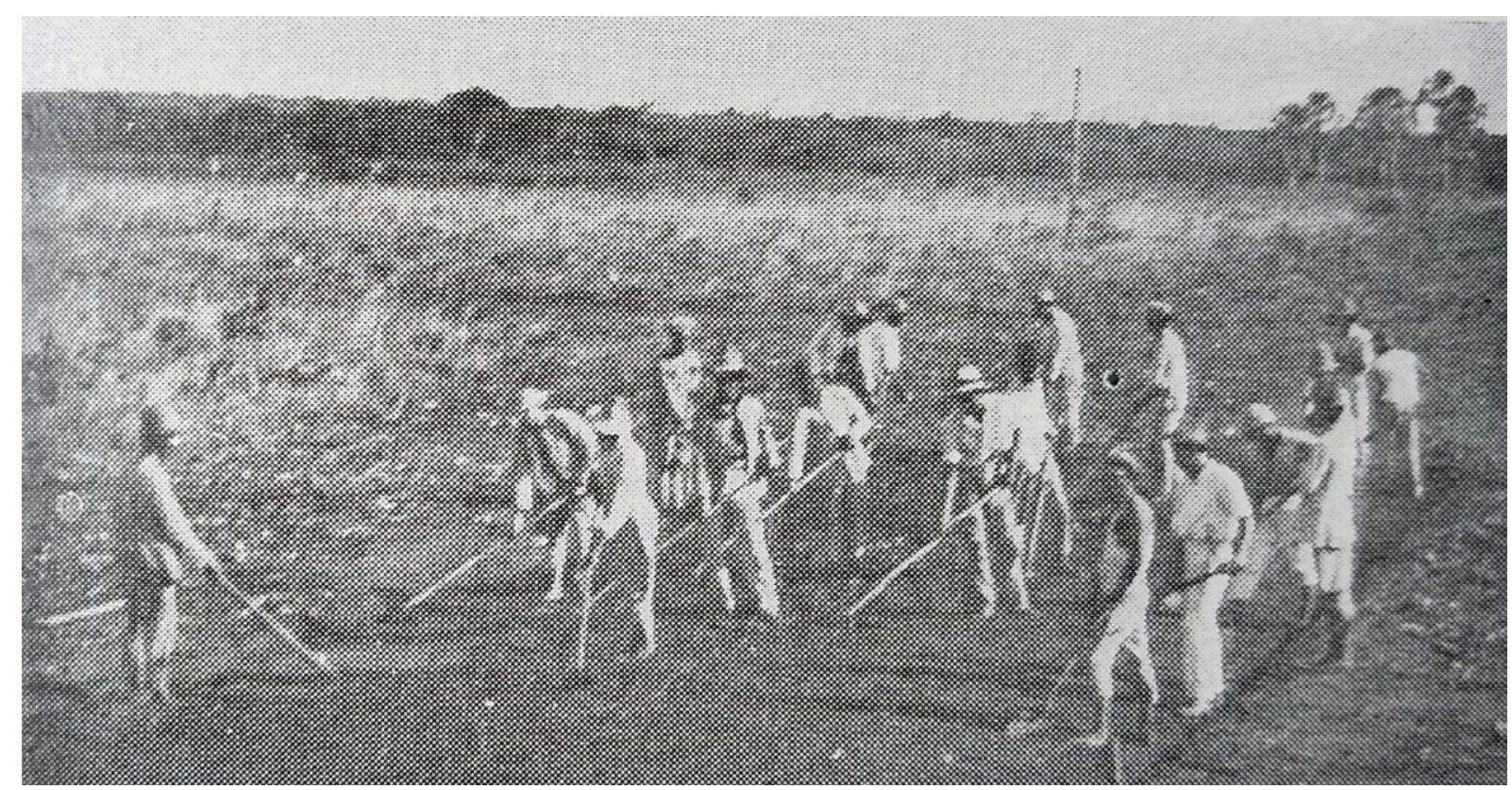

Figura 24: "Os trabalhos preparatórios: operários abrindo os primeiros arruamentos, em 1934 e 1935, nas planuras dos arredores de Campinas, onde se construiu a Nova Capital do Estado de Goiás". Legenda da publicação. Autoria desconhecida. Fonte: Alvares (1942).

O mutirão, intimamente ligado à gênese de Goiânia - e frequentemente retomado ao longo de sua história política ${ }^{28}$-, em princípio apareceria como alternativa à questão dos parcos recursos orçamentários, ao mesmo tempo que tacitamente traria consigo a exploração do trabalho, como sinalizariam Wiederhecker, Chaves e Pereira (1987). Pois, se a prática do mutirão para a construção de habitações ainda pode ter alguma justificativa - mesmo que frágil -, uma vez que "o morador está empenhado no trabalho para a construção de um bemmercadoria [...], na construção de infraestrutura urbana (rede de esgoto, água, guias e sarjetas, escolas, etc.) ela constitui um artifício cruel” (MARICATO; MORAES, 1986) à medida que, sob a retórica da atuação por um bem comum (ou a concretização de um ideal), se lançaria mão do trabalho gratuito em meio a um quadro permeado por carências. O depoimento de Antônio Elias, também sobre uma roçagem, indicaria determinadas dinâmicas na mobilização de mão de obra.

O doutor Carlos de Freitas contratou o roçado. Fez um mutirão, nóis reuniu lá e foi roçar. Ninguém recebeu nada não, foi mutirão mesmo. Ele ainda pediu ajutório. No fim da tarde, ele cantou nóis tudo. Eu tinha 50 mil réis magrinho, ainda dei a ele, ainda. Era pra mais de cem trabalhadores. Tinha trabalhador pra daná. Esparramou gente naquela chapada por toda a banda. [sic] (ELIAS apud WIEDERHECKER; CHAVES; PEREIRA, 1987, p. 15-16)

\footnotetext{
${ }^{28}$ Ermínia Maricato e Lúcia Maria Moraes, no artigo $O$ mentirão, ou melhor, o mutirão de Goiás, recuperariam o exemplo da Vila Mutirão, um conjunto habitacional construído em Goiânia na década de 1980 a partir de iniciativa do governo estadual e através do regime de mobilização que lhe dá nome. Sob o mote "mil casas em um dia", a empreitada seria revestida pelo poder político num intenso tom midiático, mediante ampla divulgação em diversos veículos de comunicação.
} 
Entre os assalariados, as frágeis condições de trabalho também se reproduziriam. Segundo Alvares (1942), registrou-se na Superintendência de Obras, ao longo de aproximadamente quatro anos, mais de quatro mil trabalhadores - um número bastante representativo visto que, de acordo com estimativas, a população de Campinas e Hidrolândia (municípios que inicialmente integrariam Goiânia) somava 14.300 habitantes no ano de fundação da nova capital (SABINO JÚNIOR, 1960). A cifra, contudo, oscilava de acordo com a disponibilidade financeira: "se havia dinheiro, crescia o número de operários em atividade, as construções prosseguiam" (ALVARES, 1942, p. 63); em contrapartida, com a escassez de recursos, o ritmo das obras era reduzido, bem como a quantidade de trabalhadores e a pontualidade dos pagamentos. $\mathrm{O}$ atraso na quitação de salários, aliás, era um problema constante, o que obrigava a adoção de saídas, no mínimo, criativas.

[...] se instalou, com grande júbilo do operariado, a conhecida "Cantina do Estado". Pode-se afirmar que foi, em linhas gerais, a primeira cooperativa que se organizou oficialmente em Goiânia: a Fazenda do Estado adiantava numerário à "Cantina", que, assim, sortia seu armazém de gêneros, roupas, sapatos e os produtos mais essenciais, de procura dos trabalhadores. [...] A princípio, esse engenhoso sistema provou regularmente: se os operários não recebiam dinheiro, tinham, pelo menos, o feijão de cada dia....Aconteceu, porém, algum tempo depois, o irremediável, como sempre...A Diretoria da Fazenda se foi atrasando em recolher as "autorizações" da "Cantina" e o seu gerente, sem verbas suficientes, não podia abastecer o armazém dos artigos necessários. A situação se agravou, acentuadamente, até que foi rescindido o contrato com a "Cantina" e esta também extinguiu. (ALVARES, 1942, p. 69)

A prática mais usual, no entanto, era a venda de salário para comerciantes e agiotas, como sinalizaria Adolfo Boari (apud GOIÂNIA, 1985), Vitorino de Freitas (apud WIEDERHECKER; CHAVES; PEREIRA, 1987) e outros tantos operários.

Eu tinha um agiota. Todo mês, eu vendia o salário do mês para ele, com desconto de 20 por cento. Dava procuração e vendia o salário para ele. E me mantinha mais ou menos durante a semana fazendo servicinhos que a gente chamava de biscates. (FREITAS, V. apud WIEDERHECKER; CHAVES; PEREIRA, 1987, p. 12)

A retenção de porcentagem nos valores a receber aconteceria, inclusive, na cantina mencionada por Alvares (1942), conforme revelaria outro depoimento transcrito no trabalho de Wiederhecker, Chaves e Pereira (1987).

O pagamento era feito por hora de trabalho. Então marcava-se as horas numa ficha e aquilo eram somadas mensalmente e pagas com 6 meses e até 8 meses de atraso, parece que houve. Então se precisava o operário de dinheiro para algum problema de emergência, ia na cantina [...]. Então a gente ia lá, eles descontavam o papelzinho e ficava com 25 por cento. Se você tinha direito a 100 cruzeiros, eles descontavam 25 pro bolso deles e devolviam 75. Depois eles recebiam lá no Estado, por que eles sempre tinham um dinheirinho, não é? (BARBOSA, S. apud WIEDERHECKER; CHAVES; PEREIRA, 1987, p. 12) 
Diante da falta de pagamento, ocorreriam diversos levantes e greves - que chegariam a ser contabilizados em relatórios da Firma Coimbra Bueno. Só no ano de 1935, por exemplo, cinco paralisações seriam levadas a cabo - sem mencionar as tentativas de greve, que seriam numerosas (COIMBRA BUENO \& CIA LTDA., 1937 apud ALVARES, 1942). Curiosamente, a gradativa diminuição dos movimentos reivindicatórios com o passar dos anos se atribuiria à melhoria da disciplina dos trabalhadores, segundo os mesmos relatórios conquanto se mencionasse outras condutas vistas como escusas.

A relativa disciplina que atualmente se vê nas Obras, é obtida a custo, e deve-se
exclusivamente à boa índole dos operários, à sua confiança na administração da
Superintendência, e no Governo. Devo notar, contudo, a existência de fatos sobre os
quais somos obrigados a fazer "vista grossa", devido às restrições administrativas já
aludidas. Tais fatos são: saída de operários para trabalhar temporariamente em obras
particulares, pouco desenvolvimento no serviço de determinados oficiais, faltas
continuadas de outros, restrições na autoridade dos Mestres, etc. Tais irregularidades
desaparecerão automaticamente com a regularidade dos pagamentos, mas são
inevitáveis no momento. (COIMBRA BUENO \& CIA LTDA., 1937 apud
ALVARES, 1942, p. 66-67)

Outrossim, além da irregularidade nos pagamentos (e das precárias condições de habitabilidade, tema que abordaremos posteriormente), outra peculiaridade inerente às relações de trabalho nos canteiros da nova capital se referiria às longas jornadas de trabalho. Evidentemente, parte das extensas jornadas se atribuiria à premência de realizar serviços extras para complementação de renda, como revelaria o maranhense Vitorino de Freitas (apud WIEDERHECKER; CHAVES; PEREIRA, 1987, p. 11), que indicaria também ser "biscateiro nos domingos e feriados. Trabalhava quase dia e noite e nas madrugadas também". Todavia, a prática também seria verificável nas obras públicas, dada a necessidade de se imprimir maior velocidade às construções - sobretudo em meio às disputas entre mudancistas e antimudancistas, de modo que preeminentemente urgia a rápida consolidação de uma estrutura mínima capaz de receber o aparato estatal que ainda se situava majoritariamente na Cidade de Goiás. Ou seja: seria regular a ampliação da exploração da mão de obra não somente através da incorporação de contingente de trabalhadores aos canteiros, quando possível, mas também avultando as horas de ofício e suprimindo folgas previstas por lei conforme sugeriria o emigrante português José Fernandes (apud WIEDERHECKER; CHAVES; PEREIRA, 1987, p. 11) ao recordar que "trabalhava das 6 da manhã às 6 da tarde, com intervalo de duas horas para o almoço. Quando era com o concreto, trabalhava dia e noite. Houve ano em que trabalhei 365 dias".

Como consequência, algumas obras seriam concluídas num lapso temporal bastante reduzido. Bernardo Élis, por exemplo, afirmaria que o edifício onde temporariamente 
funcionara a Assembleia Estadual teria sido erguido em 45 dias - fato igualmente apontado por Alvares (1942) na legenda de uma fotografia, conquanto haja incompatibilidade de datas -, algo que, mesmo considerando o pequeno porte da construção, apenas seria viável a partir da utilização intensiva da força de trabalho.

Findava 1936, melancolicamente, em meio ao recesso de 60 dias da aguerrida Assembleia. Escaldado com a crise provocada pelo Poder Legislativo, resolve o Governo transferi-lo imediatamente para Goiânia. [...] Entretanto, urgia uma Casa para o funcionamento da Assembleia; teria que ser um prédio com grande salão para o plenário, com instalações condignas, prédio cuja construção demandava tempo. Nada de vacilações: era meter os peitos. Quarenta e cinco dias após o iniciado, para o edifício entrava a Assembleia Estadual. [...] Nunca se construiu tão rapidamente em todo o Brasil Central! Também nunca um prédio feito para uma finalidade, serviu tão pouco tempo a essa finalidade. (ÉLIS apud GOIÂNIA, 1985, p. 56)

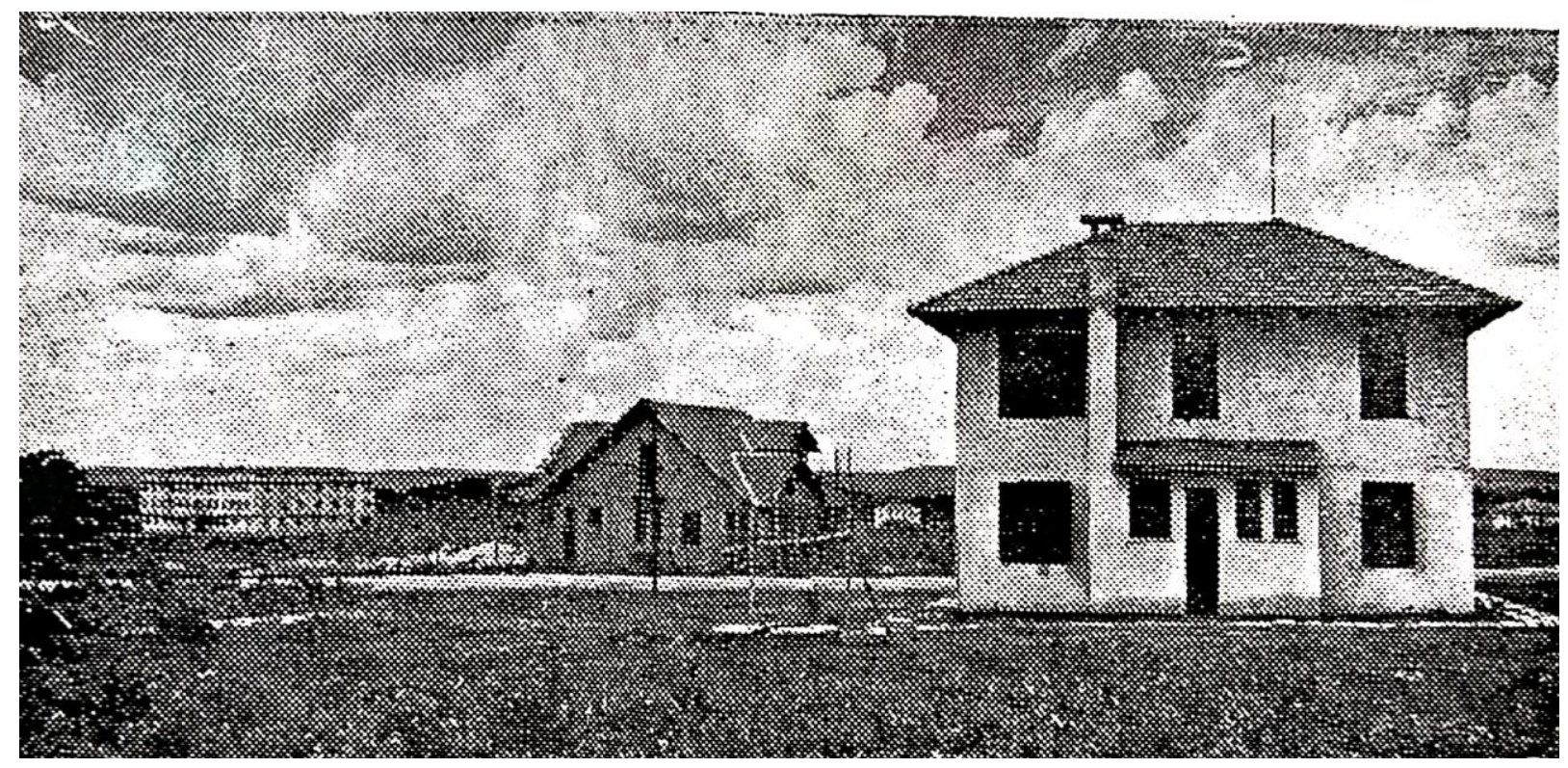

Figura 25: "O prédio da Assembleia Legislativa, na Av. Tocantins, que foi construído em quase 40 dias, em meados de 1936. Ao fundo, o edifício do 'Grande Hotel', na Avenida Goiás". Legenda da publicação. Alois Feichtenberger. Fonte: Alvares (1942).

Essas particularidades presentes nos canteiros de obra da nova capital, especialmente intensificadas pelo contexto de uma cidade em pleno processo de estabelecimento, derivariam sobretudo do caráter manufatureiro das construções - no caso, com características típicas do sistema de manufatura serial, baseado "principalmente no trabalho interno e cumulativo" (FERRO, 1976/2006, p. 113) -, que assim se configuraria mesmo mediante o emprego (parcial) de maquinário e produtos industrializados, já que por si só "não chegam a configurar uma produção industrializada" (VARGAS, 1983, p. 200). Por conseguinte, o que se verificaria na construção de Goiânia se aproximaria bastante de um cenário descrito por Nilton Vargas que, ao abordar a não-racionalização da produção habitacional do país, denotaria a existência de uma racionalidade cujo corolário implicaria na depredação da força de trabalho. 
O capital calcado sobre um processo de trabalho que não tem em vista o aumento de produtividade nem a intensificação do trabalho [...] tem de procurar outras formas para aumentar o excedente econômico. Resta-lhe, desse modo, lançar mão de métodos de organização do trabalho que podem ter um caráter depredatório da força de trabalho. Suas armas são: o estabelecimento de salários não condizentes com a subsistência operária; o aumento da jornada de trabalho; e o uso extenuante da força de trabalho sob condições laborais bastante precárias. (VARGAS, 1983, p. 206)

Naturalmente, levando em consideração limitações locais já mencionadas - tal como o quadro temporal na qual a consolidação de Goiânia se articula -, entende-se que a expectativa por sinais de uma forma de produção industrial - ou mesmo de manufatura heterogênea, isto é, "baseada principalmente na montagem de elementos pré-fabricados" (FERRO, 1976/2006, p. 113) - aqui tenderia a ser irrazoável e anacrônica. Não é essa a questão que é pertinente decantar uma vez que, recordemo-nos, as obras de Goiânia não deixariam de carregar consigo os matizes do progresso.

O que se salienta é que, por um lado, a construção da nova capital marcaria um movimento de inserção de Goiás na nova divisão de trabalho que já verificava-se em escala nacional (WIEDERHECKER; CHAVES; PEREIRA, 1987), a partir da formação de um mercado consumidor urbano e de uma classe operária - sobretudo diante da gradual incorporação do migrante proveniente do campo; ao mesmo tempo, se evidencia um status quo na forma de produção que, por razões cuja complexidade escapa aos limites desta dissertação, multiformemente se manifestaria na construção civil do país - e, não por acaso, o que aconteceria em Goiânia guardaria semelhanças com o que se observaria décadas depois próximo dali, nos canteiros de Brasília. Nesse sentido, as imagens do labor na construção da nova capital de Goiás também sinalizariam, implicitamente ou não, meandros próprios das relações de trabalho no contexto de produção manufatureira que integrariam um âmbito mais amplo.

O cunho parcelado da manufatura serial, por exemplo, marcadamente estabelecido através de equipes fragmentadas e hierarquizadas (FERRO, 1976/2006), se revelaria através dos arranjos presentes em fotografias como aquela que finda a seção anterior, onde o registro do edifício em construção se apresenta tomado por operários e outros agentes da cadeia produtiva. Em outros termos, a disposição das figuras humanas entre as bordas da captura fotográfica assume uma determinada lógica capaz de desvelar ordenamentos - funcionais e sociais - que variariam de acordo com atribuições e origens de cada um. Tomemos como exemplo outra fotografia, referente à obra da Delegacia Fiscal, datada no início de 1937. 


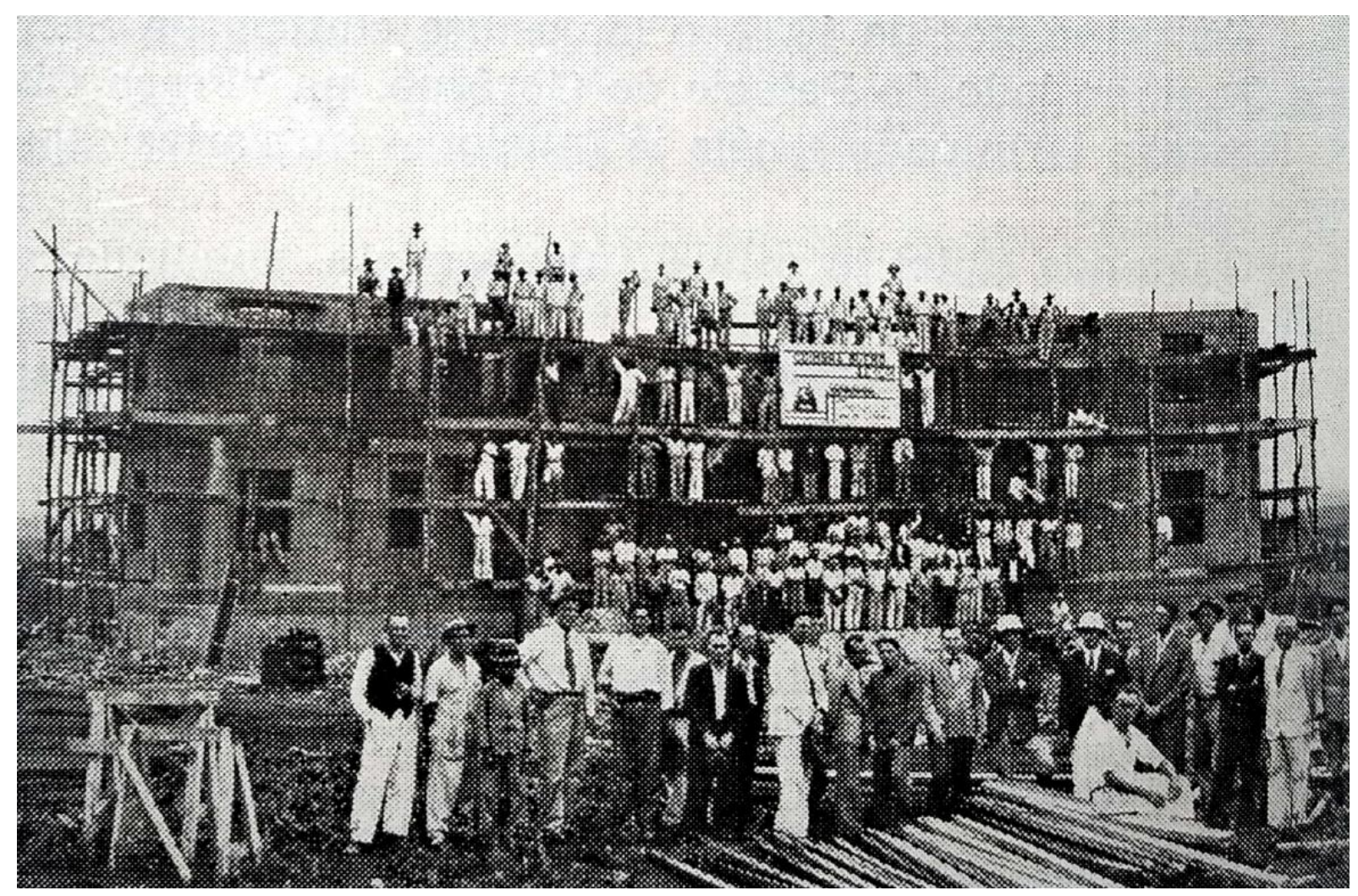

Figura 26: Delegacia Fiscal em construção. Autoria desconhecida. Fonte: Alvares (1942).

O registro traz, em primeiro plano, além das bem trajadas personalidades políticas, os irmãos Jerônimo e Aberlado Coimbra Bueno, o engenheiro-arquiteto José Neddermeyer naquele momento à frente da Seção de Arquitetura da Superintendência de Obras - e demais técnicos e mestres de obras oriundos, principalmente, dos recrutamentos em grandes centros conduzidos pela firma construtora. Esses últimos, aliás, muitos dos quais migrantes estrangeiros, como integrantes do núcleo de trabalhadores já qualificados desempenhariam uma dupla função, segundo Wiederhecker, Chaves e Pereira (1987, p. 7): “a de se responsabilizar pela execução das tarefas mais técnicas do processo construtivo e, como responsáveis pela rotina de trabalho, pelo treinamento e subordinação dos trabalhadores". Mais especificamente no que se refere à organização laboral, dada a fragmentação do trabalho, Ferro (1976/2006) ressaltaria o encargo do mestre de obras na totalização do trabalhador coletivo, isto é, na ligação entre as equipes - e, embora se tratasse de um "elo secundário na cadeira de poderes” (FERRO, 1976/2006, p. 117), não deixaria de exercer cotidianamente a posição hierárquica que lhe era delegada.

[...] Os pedreiros e serventes tinham uma certa dificuldade em bater um papinho com os chamados mestres-de-obras porque eram todos estrangeiros. [...] Eram espanhóis, alemães e alguns italianos. Na sua maior parte, eram espanhóis. Então não tinha boca pra gente. Não havia relacionamento bom entre nós e estes mestresde-obras. Havia servilidade. Tinha uma coisa: o aprendiz que passasse na mão daquela gente tinha que dar oficial mesmo. Porque não era mole não, e era correndo. 
Tinha que fazer o serviço, era correndo, era velocidade e muito bem feito. (BARBOSA, S. apud WIEDERHECKER; CHAVES; PEREIRA, 1987, p. 9)

Por outro lado, em que pese estarem no mesmo plano de destaque na fotografia, os mestres de obras se distinguiriam dos homens do saber técnico. O par engenheiro-mestre, conforme expõe Vargas (1983), compreenderia formações distintas onde o primeiro representaria o conhecimento científico e o segundo, o conhecimento empírico.

Esta interferência da ciência no processo de trabalho configura na organização do canteiro o par engenheiro-mestre com uma nítida separação de funções. O primeiro, formado no ensino acadêmico, detém o conhecimento técnico-científico e fiscaliza sua aplicação na obra; representa também a empresa, sendo o responsável pela administração do empreendimento. O mestre, formado no canteiro, chega a essa posição depois de muitos anos de labuta em várias funções e após ter provado que sabe assumir a liderança dos trabalhadores; serve, portanto, de tradutor das ordens emanadas do engenheiro; em virtude de sua origem social, conhece a linguagem e os costumes operários; sabe como dosar persuasão com coação para convencer o trabalhador a produzir. Este par engenheiro-mestre transparece a contradição [...] entre o científico e o empírico, o "moderno" e o "arcaico", e o capital e o trabalho. (VARGAS, 1983, p. 197)

Ainda na fotografia da obra da Delegacia Fiscal, em segundo plano, se disporiam, em maior número, os operários, entre os andaimes de madeira e a placa de obra da Firma Coimbra Bueno. Compondo a força de trabalho braçal, tais trabalhadores seriam atraídos à nova capital principalmente a partir de correntes migratórias internas, "motivados pela esperança de uma nova vida e atraídos pelo fascínio que o capital exerce, já que está sendo criado um mercado de trabalho promissor" (WIEDERHECKER; CHAVES; PEREIRA, 1987, p. 8). E, conquanto se afirmasse que a contratação de operários seguia termos exigentes nos recrutamentos - era obrigatório apresentar referências e atestados de firmas de engenharia para provar já ter trabalhado nos ofícios, por exemplo (COIMBRA BUENO \& CIA LTDA., 1936 apud MONTEIRO, O. S. N., 1938) -, muitos dos trabalhadores em Goiânia seriam admitidos sem experiência, como indicaria Vitorino de Freitas.

Eu vim pra Goiânia tentar serviço. Lutei, consegui um serviço de carpinteiro, que eu não era carpinteiro. Eu aventurei. Eu precisava ganhar, que eu não queria furtar. Eu disse: sou carpinteiro, e ele me admitiu como carpinteiro. (FREITAS, V. apud WIEDERHECKER; CHAVES; PEREIRA, 1987, p. 10)

Nos canteiros de Goiânia, a absorção de mão de obra não qualificada seria justificada, em parte, pela tão enunciada escassez de pessoal. Todavia, somente seria possível diante do arranjo baseado no trabalho parcial, no bojo da produção manufatureira, conforme expõe Monegatto (2013, p. 91).

As estreitezas e as deficiências do trabalhador parcial tornam-se perfeições quando ele é parte integrante do trabalhador coletivo. A desvalorização relativa da força de trabalho, decorrente da eliminação ou da redução dos custos de aprendizagem, redunda para o capital em acréscimo imediato de mais valia, pois tudo o que reduz o tempo de trabalho necessário para reproduzir a força de trabalho aumenta o domínio 
do trabalho excedente. Todas essas são características na construção civil, principalmente habitacional, brasileira. (MONEGATTO, 2013, p. 91)

Assim, como efeito, Monegatto (2013, p. 92) ainda afirmaria que "a construção dos edifícios passou a incorporar um conhecimento técnico e científico independente do saber operário", o que seria exemplificado pela adoção de técnicas construtivas pouco comuns na região, como o concreto armado. Essa lógica demanda, essencialmente, um olhar cauteloso, uma vez que a incorporação de determinados saberes se viabilizaria pela trasladação de técnicos e trabalhadores especializados. No entanto, não se pode desconsiderar um movimento de transmissão de conhecimento nos canteiros, especialmente pautado na oralidade, "forma predominante de o trabalhador iniciar a sua aprendizagem" (VARGAS, 1983, p. 197). É nesse sentido que Alvares (1942) descreveria Goiânia como uma oficina de aprendizado para o brasileiro do Oeste.

A realização de Goiânia também prestou esse valioso benefício aos nossos patrícios oesteanos: foi uma verdadeira escola de obreiros, pedreiros, carpinteiros, marceneiros, pintores, eletricistas, etc. e centenas de oficiais, ajudantes, aprendizes tiveram, nas obras da Nova Capital, o ensejo de adquirir conhecimento e de se tornarem uteis ao seu Estado, num meio que era tão falho desses recursos. (ALVARES, 1942, p. 178)

Ainda na esteira das relações produtivas que permeariam as imagens do labor, é importante destacar que a sequência engenheiro/arquiteto-mestre-encarregado pressupõe, por conseguinte, a cisão entre a concepção e a execução - uma prática não necessariamente nova, mas acentuada com a substituição do artífice pelo migrante rural nas construções do país (XAVIER PEREIRA, 1988 apud MONEGATTO, 2013) -, de modo que o desenho assumiria o papel basilar de documento de trabalho tanto por seu potencial enunciativo quanto pela capacidade definir as parcelas da produção com maior exatidão, "da regulamentação da produção à sua organização, da mensuração externa à sistematização de operações" (FERRO, 1976/2006, p. 154). E se Deforge (1970 apud FERRO, 1976/2006, p. 153) indicaria que "um desenho completo é uma ordem", se verificariam casos extremos nas obras de Goiânia, conforme recordaria o pioneiro Adolfo Boari.

- O Sr. estava contando que participou da construção da torre do relógio...

- Sim, eu peguei a obra da fundação e entreguei tudo aquilo. [...]

- Mas o Sr. estava contando que a construção daquela torre não foi supervisionada por engenheiro nenhum...

- Não, engenheiro nenhum. Eu recebi a planta e entreguei tudo pronto, sem que o engenheiro fosse lá. (BOARI apud GOIÂNIA, 1985, p. 18)

Outrossim, o descolamento da concepção e da execução também implicaria na existência de dois contextos distintos, o escritório e o canteiro, que curiosamente transpareceriam de maneira recorrente, através dos registros iconográficos, em publicações e 
álbuns. O escritório, por exemplo, figuraria por meio de capturas das várias seções abrigadas nas dependências da Superintendência de Obras, no edifício da Secretaria Geral, como a Seção de Construção e a Seção de Contabilidade. Tomada por técnicos debruçados sobre pranchetas, se teria ainda a Seção de Arquitetura, onde é possível identificar José Neddermeyer.

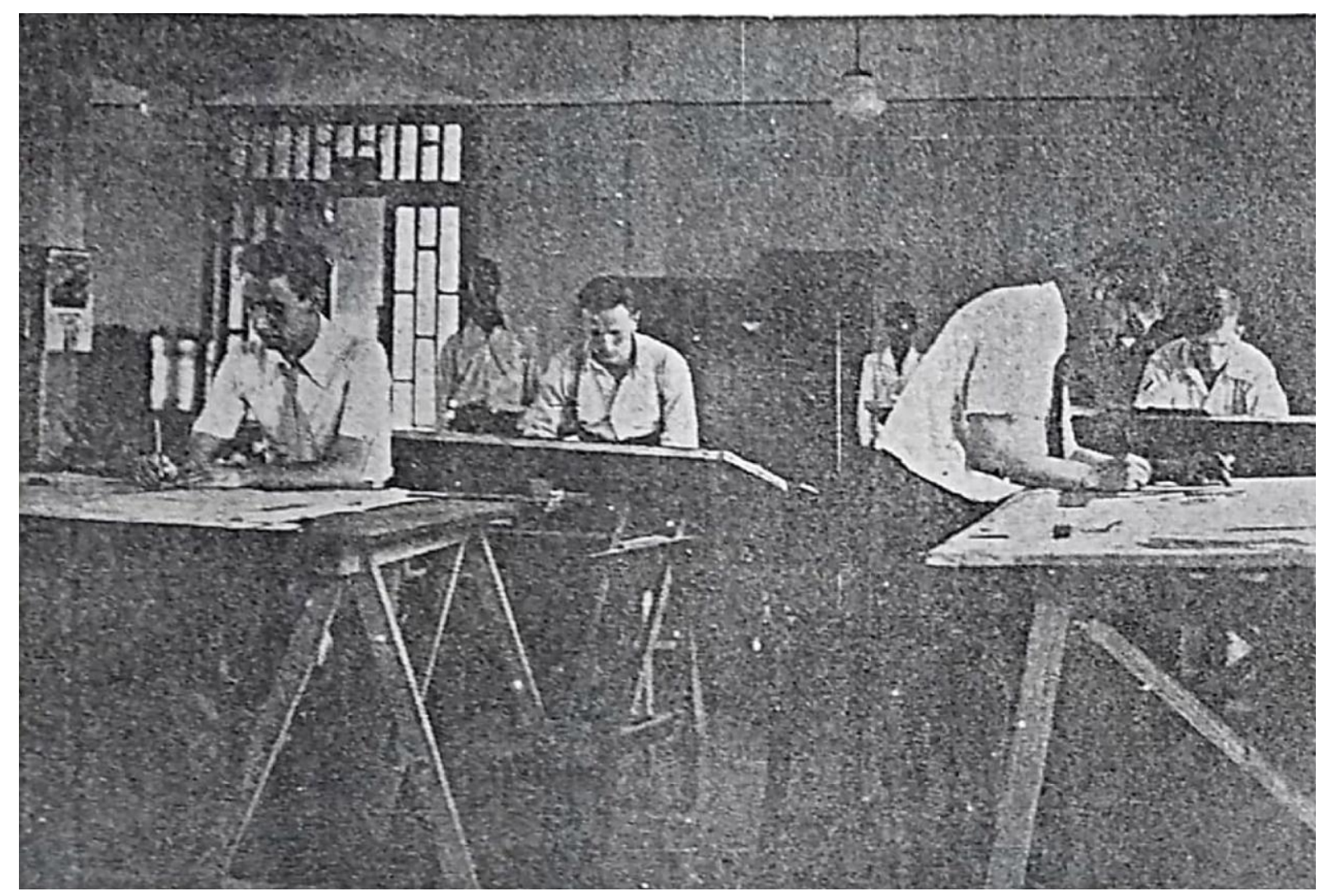

Figura 27: Seção de Arquitetura. Autoria desconhecida. Fonte: O. Barbosa (c. 1939)/Acervo do SEPLANH.

Já o canteiro, em adição às fotografias apresentadas nas páginas anteriores, seria representado inclusive através de traços, como num croqui que diria respeito à obra do CineTeatro Goiânia - que, por sua vez, possivelmente derivaria de uma das fotografias do mineiro João de Paula Teixeira Filho, o Paratéca, primeiro fotógrafo nomeado em Goiás (MUSEU DA IMAGEM E DO SOM DE GOIÁS, 2002). No debuxo, a estrutura de concreto ainda inconclusa, ressaltada por traços verticais e escalonados - e num efeito intensificado pelas escoras -, seria permeada por operários, dispostos em todos os cantos e realizando múltiplas atividades manuais. Apesar de exíguas, duas figuras na porção esquerda do croqui chamariam atenção não apenas por utilizarem trajes diferentes, mas por conversarem entre si portando, nas mãos, algo que parece ser um projeto. Estes aparentemente seriam mestres de obra e técnicos, figurando a presença de diferentes agentes na produção atuantes na construção. 
passou na minha mão, pelo menos o material. De forma que tinha um engenheiro, um pedreiro e eu, como servente. Eles entendiam da parte técnica, da parte de aperfeiçoamento, era com eles. Mas na parte grosseira de preparar o material, passou nas minhas mãos. (FREITAS, C. F., 2004 apud MATTOS, S. C., 2008, p. 48)

O croqui, que habitaria páginas no compêndio do Instituto Brasileiro de Geografia e Estatística (1942) e, posteriormente, na publicação de Artiaga (1949), sugeriria uma imagem comum no cotidiano da nova capital, sobretudo inerente à cidade-obra, repleta de canteiros como tal.

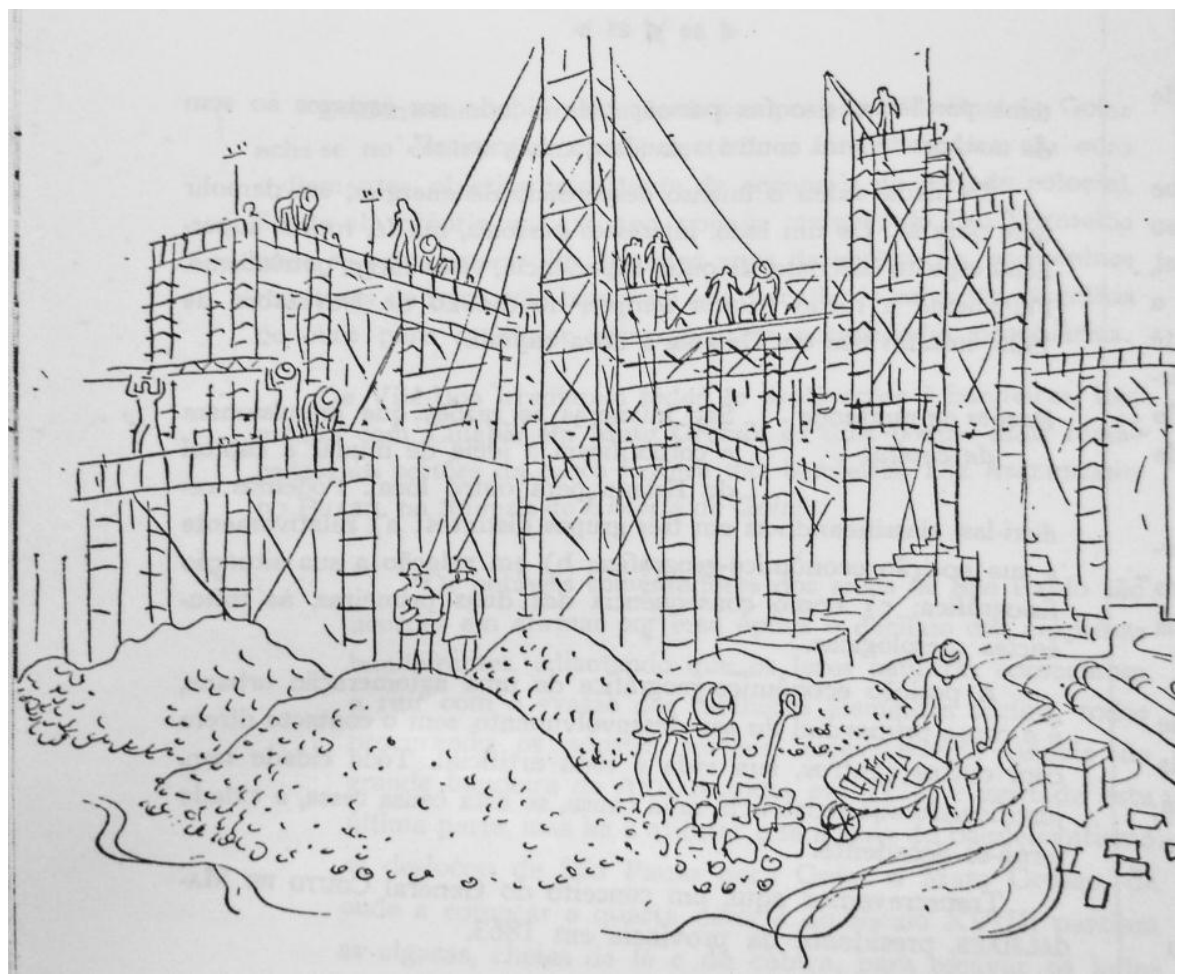

Figura 28: Croqui da obra do Cine-Teatro Goiânia. Autoria desconhecida. Fonte: IBGE (1942).

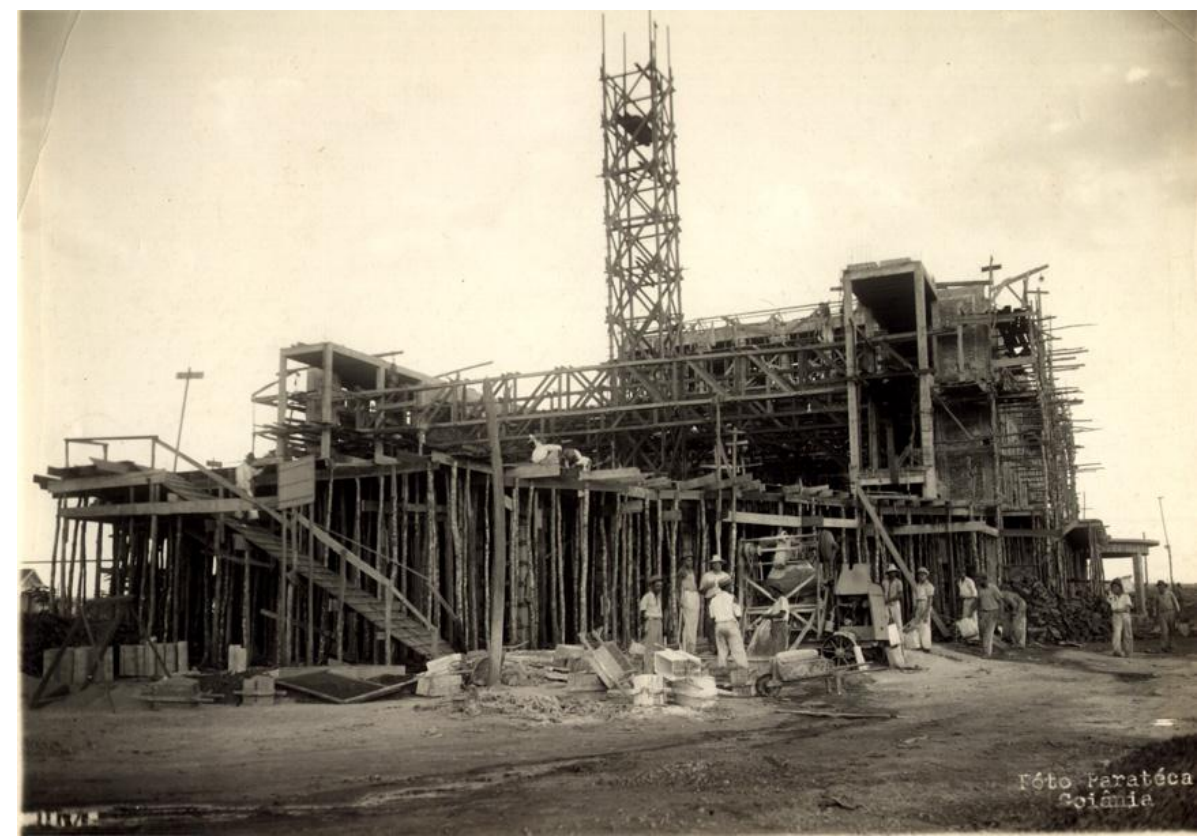

Figura 29: Construção do Cine-Teatro Goiânia, década de 1940. Foto Paratéca. Goiânia-GO. Acervo MIS/GO. 
Ademais, além das construções em si, outras facetas comporiam a iconosfera do trabalho. As imagens do labor se dariam nas próprias obras, mas igualmente se estenderiam à exploração de matéria-prima local - para assegurar o fornecimento regular de materiais de construção -, às provas de resistências de materiais - em princípio, conduzidas pela parcela especializada da mão de obra - e à confecção de elementos construtivos, como ladrilhos e esquadrias, com o intuito de minimizar custos e as dificuldades de deslocamento decorrentes de compras em distantes centros. Vale atentar, ainda, para as legendas destas fotografias nas publicações, em geral extensas, conferindo sentidos próprios aos registros dos fotógrafos - e demonstrando uma representativa atuação na sedimentação de discursos.

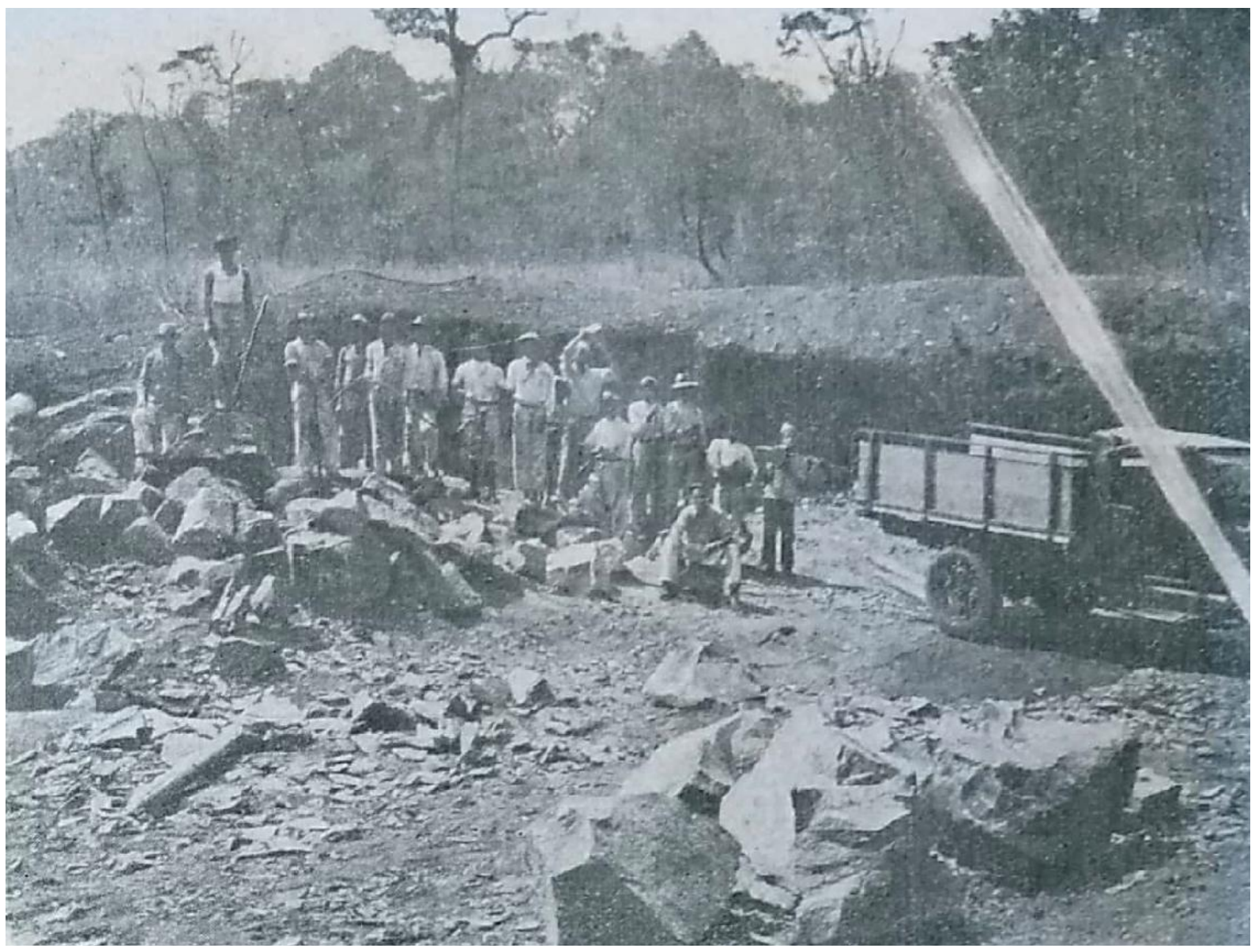

Figura 30: "Extração das primeiras pedras que serviram para a construção da cidade". Legenda da publicação. Autoria desconhecida. Fonte: IBGE (1942). 


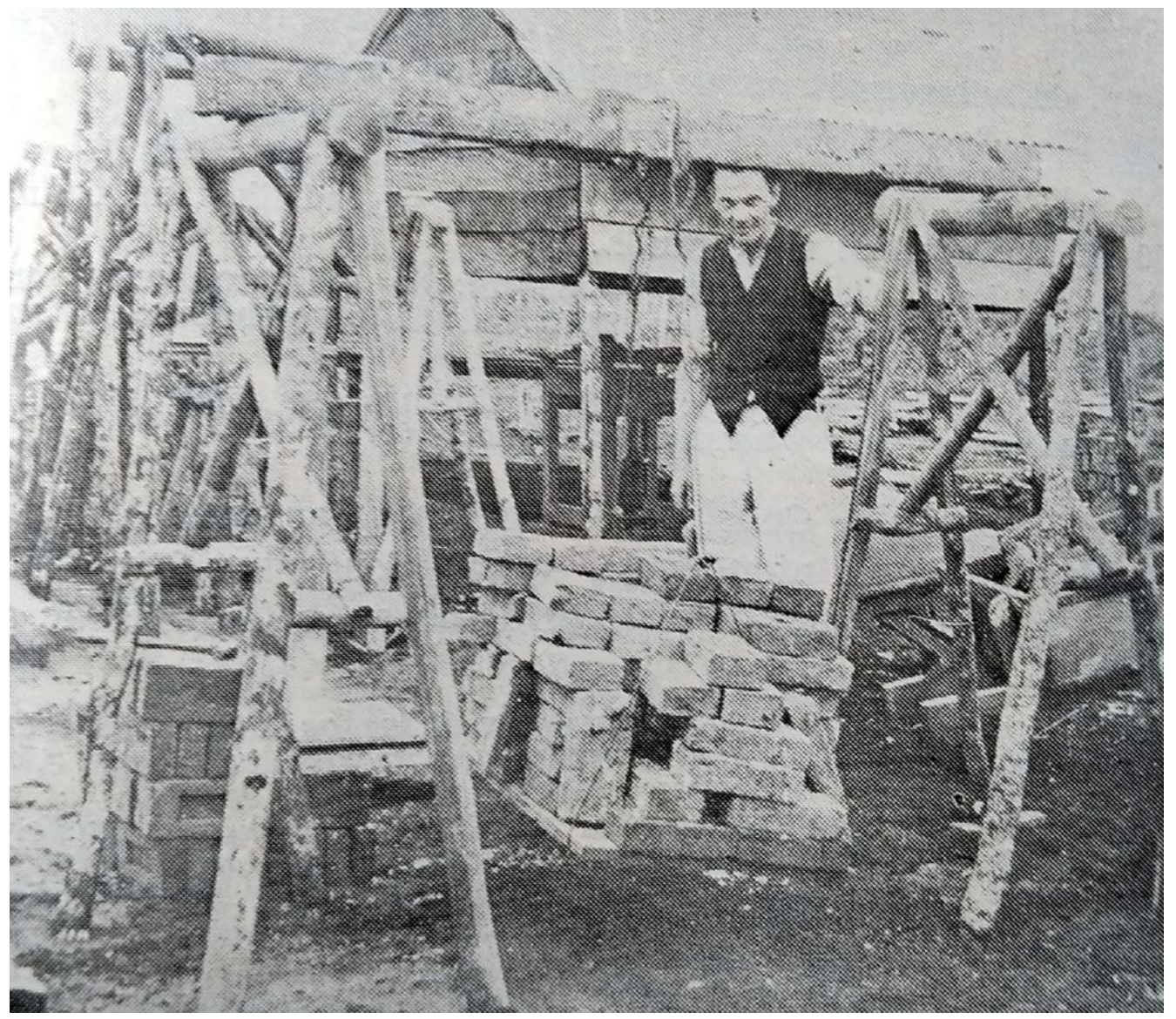

Figura 31: "Os materiais sempre foram submetidos a provas de resistência: vê-se a experimentação das vigas que eram empregadas nas obras". Legenda da publicação. Autoria desconhecida. Fonte: Alvares (1942).

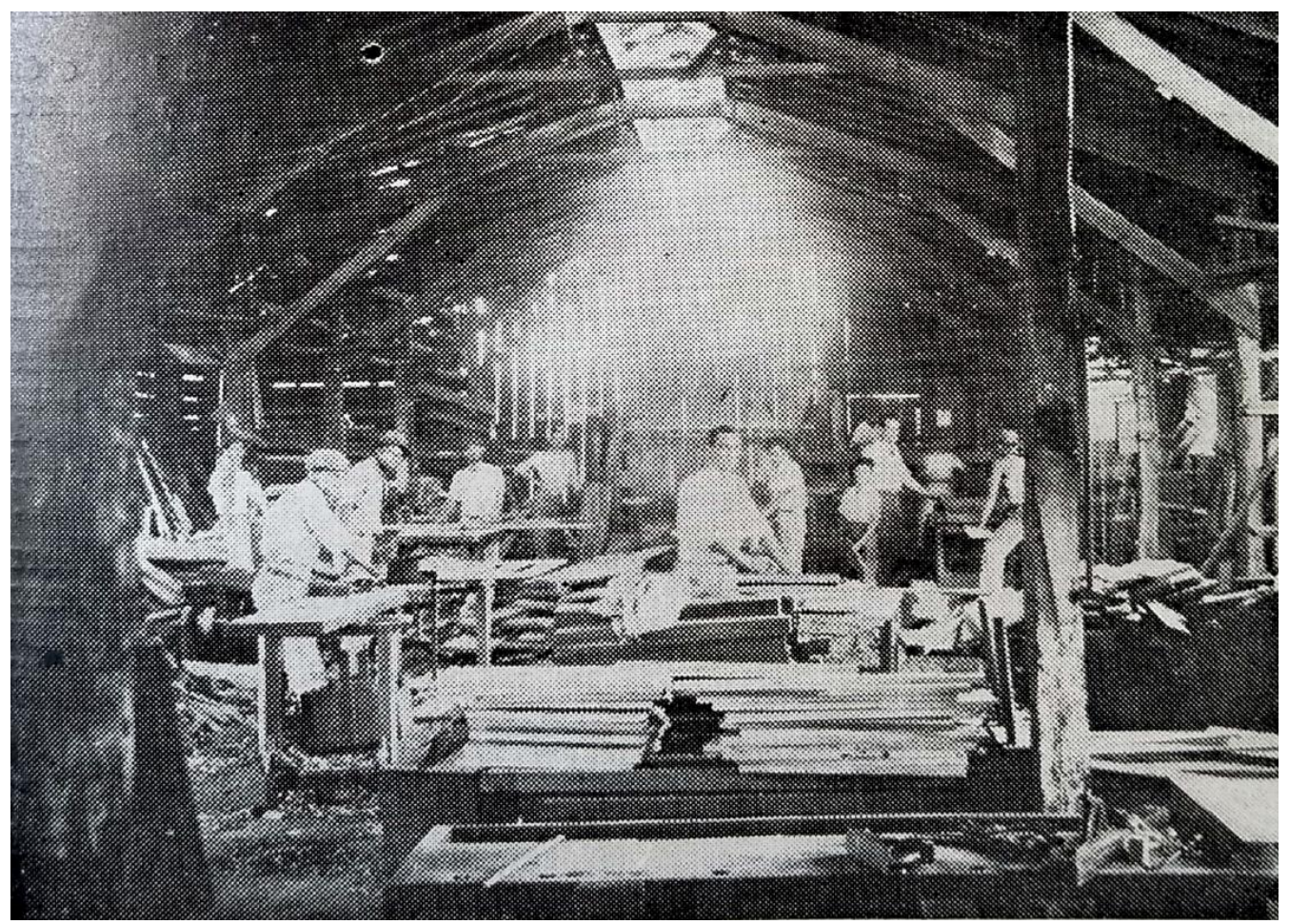

Figura 32: "A marcenaria do Estado, reaparelhada pelos engenheiros Coimbra Bueno, no bairro 'Botafogo': foi uma das indústrias locais que melhores resultados trouxeram, para a economia das obras; todas as esquadrias e mobiliário, mesmo de fino acabamento, foram executadas nessa marcenaria". Legenda da publicação. Autoria desconhecida. Fonte: Alvares (1942). 
Na cidade em construção, onde tudo aparentava estar por fazer, o progresso e o labor caminhariam juntos, portanto, apesar de supostas contradições - que se traduziriam, na verdade, em simultaneidades. Os traços de modernidade da nova capital somente se concretizariam mediante um amplo movimento que, por um lado, reverberaria num processo de dinamização local - da expansão demográfica ao fomento de indústrias, como aquelas voltadas para produção imediata às construções - e, por outro, revelaria os limites da implantação de uma cidade nova numa zona de fronteira, permeada pelas múltiplas carências que decorrem desta condição. Assim, o operário, privilegiada personificação do labor empreendido na construção de Goiânia, seria um dos elementos que se situaria nesta dialética, de modo que as imagens que daí adviriam se imbuiriam em ambivalências. No entanto, ainda haveria outras representações da cidade-obra que seriam igualmente capazes de evidenciar as acomodações especialmente presentes ao longo dos primeiros anos da nova urbe. Para efeitos didáticos, e sem pressupor a inexistência de concomitâncias em outras facetas, chamamo-las de imagens das coexistências.

\subsection{A construção e as imagens das coexistências}

Felizmente todos os óbices foram vencidos e aí está Goiânia em pleno florescimento. Tanto mais valor tem esse seu desabrochar porque não foi cidade criada com pompa e altos dotes. Ela se fez desde a primeira edificação, que foi o palácio do governo, através de todas as vicissitudes, à custa ainda do carro de boi, desse mesmo carro de boi dos outros tempos da conquista. Foi esse mesmo carro de boi que nos serviu para movimentar a terra na construção das pistas para o aeroporto da cidade. (GOIÂNIA..., 1942, p. 3)

As palavras acima, proferidas por Attilio Corrêa Lima numa entrevista ao jornal carioca A Noite, ajudariam a sintetizar o paradoxal quadro manifesto na construção de Goiânia. O avião, considerado "o maior propulsor do progresso no oeste" (ALVARES, 1942, p. 35), curiosamente apenas chegaria à cidade pela ação do carro de boi, instrumento que deteria um caráter rudimentar e longínquo - lembremo-nos do desenho de Thomas Ender -, mas também valoroso para a execução de serviços fundamentais, como a regularização do terreno do campo de pouso. Logo, se o título da seção onde a passagem se encontra - "onde o carro de boi é mais útil que o automóvel” (GOIANIA..., 1942, p. 3) - a princípio poderia causar estranheza, num momento em que particularmente havia cerca de 54 carros de boi para cada caminhão ou 3 carroças para cada automóvel - conforme dados apresentados no Álbum de Goiaz (BARBOSA, O., c. 1939) -, a tração animal, talvez o maior símbolo das raízes agrárias do estado onde a nova capital assentava-se, de fato seria uma importante força motriz em direção ao progresso. 
Não que inexistissem outros meios. Caminhões apareceriam, entre um registro e outro, em frente ao Palácio, pelas ruas da cidade, ou próximos aos locais de extração de materiais, auxiliando no seu transporte. Concomitantemente, os irmãos Coimbra Bueno disporiam de um veículo oficial na Superintendência de Obras, um Barata Ford - estampado nas páginas da publicação de Alvares (1942) -, para visita às obras. E não se pode deixar de citar ainda o famoso rolo-compressor, que seria fotografado em frente às estruturas provisórias, de madeira, como aquela que abrigaria o Escritório Central (enquanto o edifício da Secretaria Geral não era finalizado). Aparentemente, sua presença traria deslumbramento, sobretudo entre as crianças, que pareceriam perfilar-se para vislumbrar a máquina - ou para figurarem na imagem, ou ambos. Posando para o registro, também se vê Jerônimo Coimbra Bueno, imediatamente junto ao rolo-compressor.

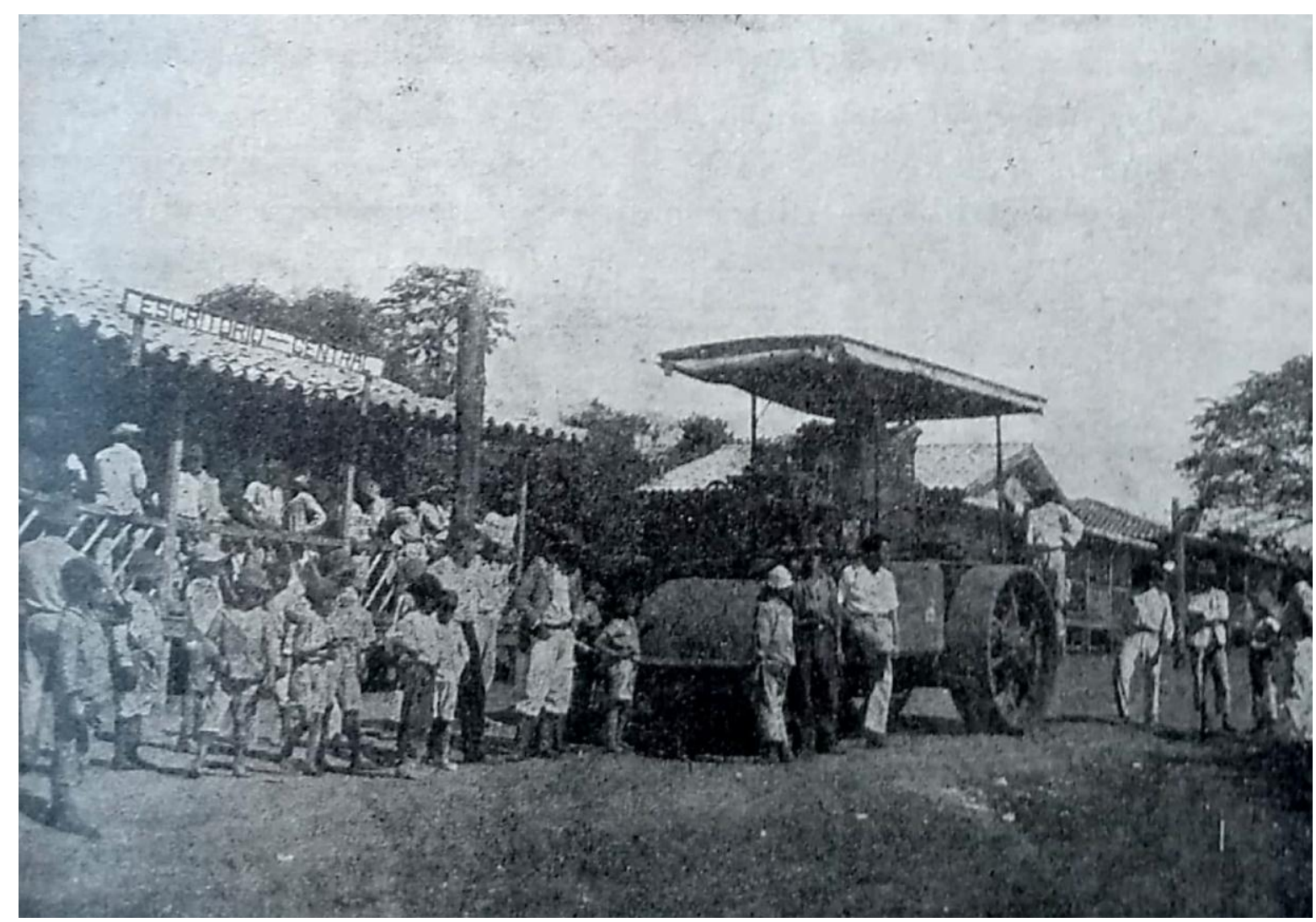

Figura 33: Rolo-compressor em frente ao Escritório Central. "Acampamento das Obras de Goiânia". Legenda da publicação. Autoria desconhecida. Fonte: O. S. N. Monteiro (1938).

Entretanto, se trataria de equipamentos que nem sempre seriam suficientes para atender as necessidades, seja pela obsolescência, seja pela quantidade frente aos serviços a executar. Recordemo-nos, por exemplo, que Pedro Ponchet Meireles (apud GOIÂNIA, 1985, p. 148) sugeriria uma inadequação do compactador, ao indicar que não sabia "onde arranjaram esse museu para tirar o [rolo-]compressor velho". Outrossim, os próprios relatórios da Firma Coimbra Bueno similarmente mencionariam o problema para justificar as 
dificuldades em manter um ritmo satisfatório no andamento das construções - uma vez que a deficiência de transportes para acarrear os materiais de produção local, decorrente do quadro de "caminhões velhíssimos e em péssimo estado de conservação, combustível caríssimo e cujos estoques eram forçosamente reduzidos a um tal ponto que comumente se esgotavam" (COIMBRA BUENO \& CIA LTDA., 1936 apud MONTEIRO, O. S. N., 1938, p. 453) implicariam em recorrentes atrasos. E, em contraposição ao veículo da Superintendência de Obras, ainda haveria o pitoresco caso do mestre de obras que andava a cavalo "pois era tudo distante demais, não havia jeito de andar a pé, e nem havia carro pra nada, nem estradas" (FARIA FILHO apud GOIÂNIA, 1985, p. 38).

Em 1934, somente dois grandes prédios estavam sendo erguidos neste descampado: o Palácio do Governo e o Grande Hotel. O mestre de obras dessas construções vestia-se como um cowboy americano e chamava-se Serrano. Fazia, durante várias vezes ao dia, o percurso Palácio-Grande Hotel montado num belo cavalo arriado com toda pompa a que tinha direito. Foi a primeira e última vez que vi uma fiscalização de obras na capital do Estado feita a cavalo. (GODOI apud GOIANIA, 1985, p. 232)

Nesse sentido, as múltiplas temporalidades permeariam o cotidiano na construção de Goiânia, assim como suas representações. Diante das variadas restrições, todos os meios disponíveis seriam válidos para dar seguimento às atividades e assim, soluções que poderiam ser vistas de maneira pejorativa, na verdade tenderiam a seguir o tom da entrevista de Attilio Corrêa Lima: o florescimento de um capital moderna em pleno sertão, erguida em meio a todos os óbices e acomodações, reservaria maiores méritos. É especialmente sob essa perspectiva que, em determinados casos, não haveria parcimônia na inclusão de fotografias que poderiam contraditar a modernidade enunciada em discursos. O suposto contrassenso marcaria o encontro de duas realidades, ao mesmo tempo que pressupunha a gradativa passagem do estado de atraso ao estado de progresso - como sugeriria o emprego do pretérito na legenda de uma fotografia presente na obra de Alvares (1942).

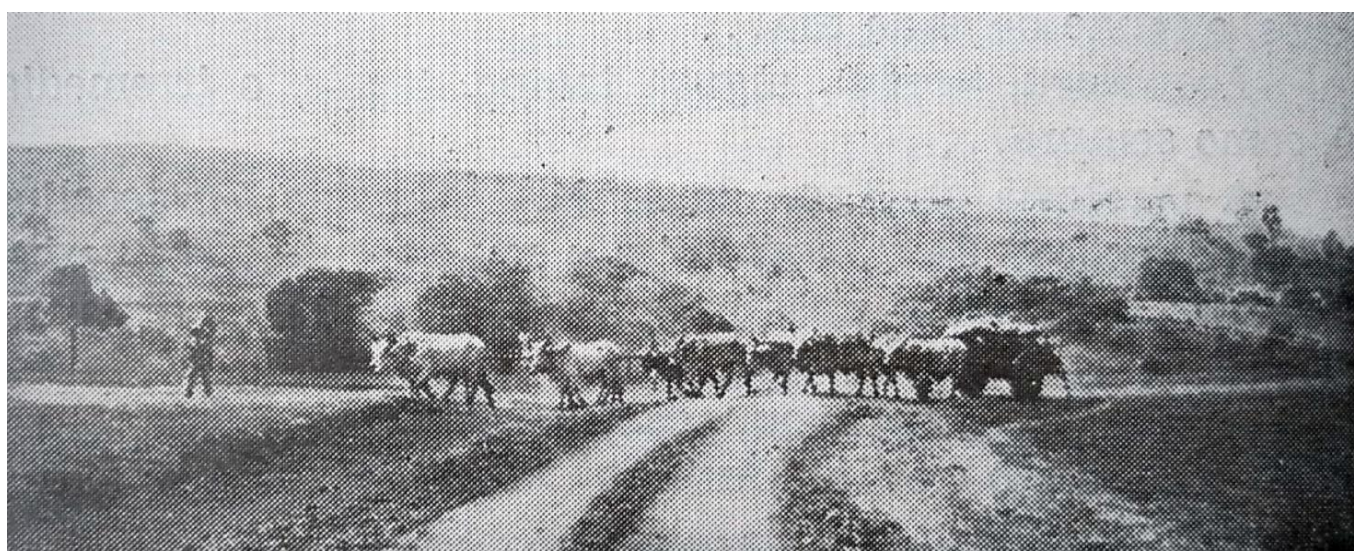

Figura 34: "Os problemas do transporte. No transporte de mercadoria e de abastecimento, era usual o aproveitamento do carro-de-boi". Legenda da publicação. Autoria desconhecida. Fonte: Alvares (1942). 
Em meio à cristalização das representações, as legendas das fotografias, aliás, assumiriam um papel de destaque, haja vista que poderiam embutir numa mesma imagem conotações diferentes - de acordo com o contexto na qual se inserisse e especialmente diante do deslocamento da figura do fotógrafo daquela do jornalista/escritor/editor. Desta forma, potencialmente diferiria o modo como os elementos visuais seriam assimilados e consumidos através das legendas, sem as quais, segundo Walter Benjamin (1931/1987, p. 107), "qualquer construção fotográfica corre o risco de permanecer vaga e aproximativa" - ainda que nem sempre apontassem caminhos consonantes às intenções originais.

[...] as fotos se transformam em autos no processo da história. [...] Essas fotos orientam a recepção num sentido predeterminado. A contemplação livre não lhes é adequada. Elas inquietam o observador, que pressente que deve seguir um caminho definido para se aproximar delas. Ao mesmo tempo, as revistas ilustradas começam a mostrar-lhes indicadores de caminho - verdadeiros ou falsos, pouco importa. Nas revistas, as legendas explicativas se tornam pela primeira vez obrigatórias. É evidente que esses textos têm um caráter completamente distinto dos títulos de um quadro. (BENJAMIN, 1931/1987, p. 174-175)

Se esses pensamentos de Benjamin demandam uma leitura cautelosa, uma vez que as legendas não necessariamente carregam consigo o compromisso de viabilizar uma mediação fidedigna - ou uma interpretação iconológica, conforme os termos de Kossoy (1988/2014) -, em outra via pode-se compreender sua inserção no campo da intencionalidade - e possivelmente por isso Benjamin não demonstre inquietude em recuperar a veracidade destes "indicadores de caminho".

Os propósitos que movem a construção de discursos e narrativas, portanto, também se revelariam nas legendas das fotografias, presentes nas variadas plataformas de reprodução. E como exemplo, tem-se um registro composto por alguns burros de carga que, em meio às veredas, carregariam sobre seus lombos telhas cerâmicas. Na publicação de Alvares (1942, p. 72), a fotografia seria acompanhada da seguinte legenda: "as dificuldades de transporte em Goiás. Material de construção transportado em cangalhas, no lombo de burros". Conquanto a legenda fosse genérica, sem precisar qualquer localização, se daria a entender que a captura diria respeito às obras de Goiânia - tanto pelo teor do livro de Geraldo Alvares quanto pela inserção da fotografia, num capítulo que trataria do problema de pessoal e de materiais na construção da nova capital. Já no Álbum de Fotografias sobre o Planejamento e Construção da Cidade de Goiânia - uma composição anteriormente datada e de finalidade muito específica, própria para ser encaminhada a Getúlio Vargas -, a mesma fotografia se disporia junto à legenda “Goiaz. O transporte na Velha Capital” (NETO, 1937/1995, p. 62). Se atribuiria à imagem, destarte, a propriedade de sintetizar as condições de vida na Cidade de Goiás, reforçando as antíteses que arrimariam a transferência da sede administrativa do 
estado. Como veremos posteriormente, esse nexo permearia todo o álbum encomendado pelo interventor Pedro Ludovico.

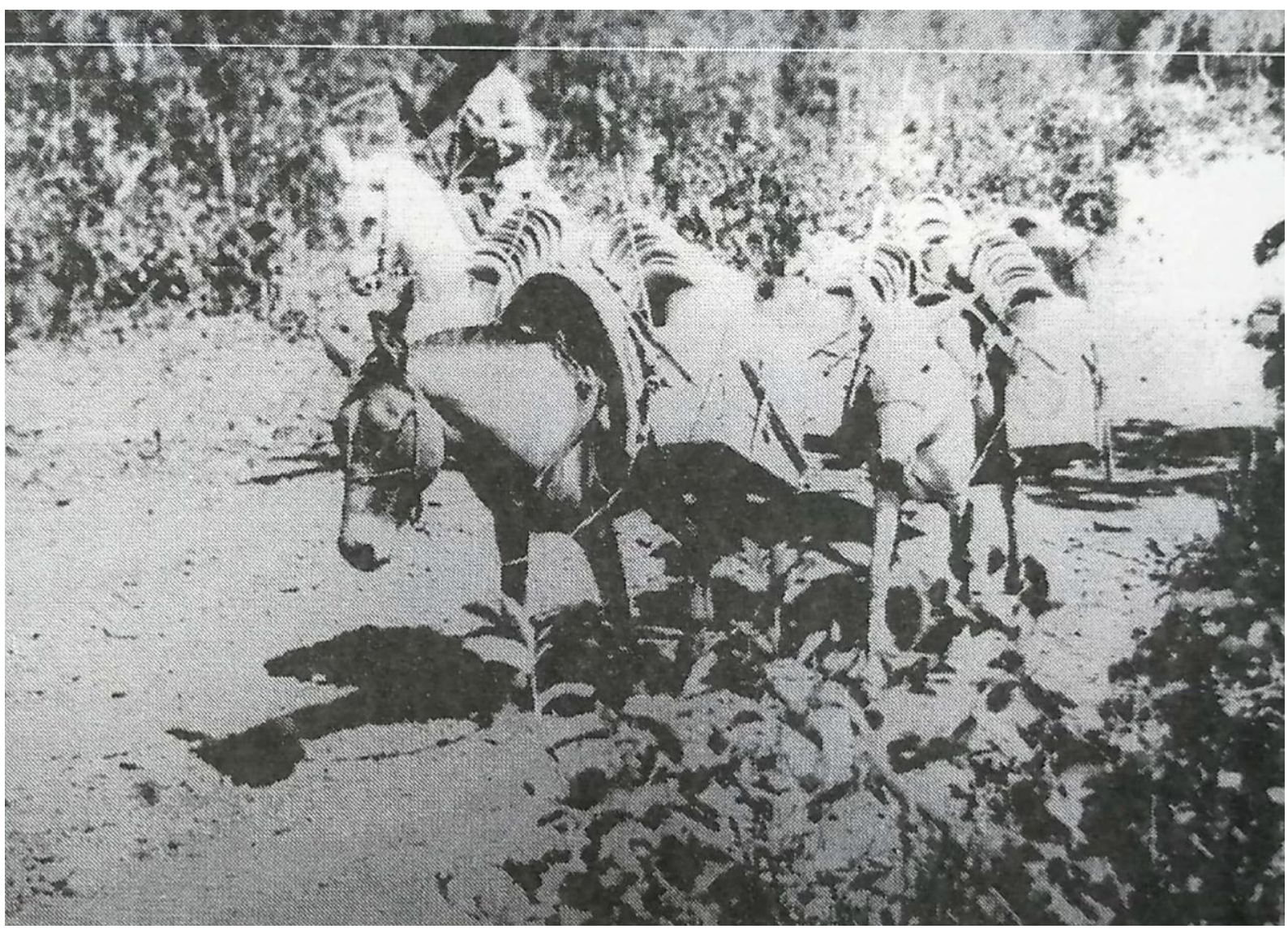

Figura 35: Burros de carga. Autoria desconhecida. Fonte: Neto (1937/1995)/Acervo do MIS/GO.

Outras fotografias, no entanto, não deixariam dúvidas à medida que evidenciariam com clareza as coexistências na construção de Goiânia. E dentre elas, uma das mais icônicas, profusamente reproduzida em publicações da época e ainda hoje ativa no imaginário goianiense, diz respeito ao registro do carro de boi na região do Centro Cívico.

Visualmente, a dialética se articularia principalmente diante do jogo de planos e signos capturados por Alois Feichtenberger. Ao fundo, se apresentariam em meio ao terreno roçado dois prédios públicos, de linhas sóbrias e horizontalizadas: o Palácio do Governo e a Secretaria Geral do Estado - este último, diga-se de passagem, hoje também abriga o Museu da Imagem e do Som de Goiás. Imediatamente em frente aos edifícios, operários dividiriam o espaço com materiais, entulhos e alguns postes de madeira - esparsos ao longo do Centro Cívico. Há ainda a presença de maquinário e caminhões, não muito distantes de uma discreta carroça - nas proximidades do vão entre os edifícios. E, em primeiro plano, um rolo compactaria o solo movido por três juntas de boi, destacados pela proximidade ao observador. Diante das várias dimensões que a representação consigo traz, é como se, em meio às 
simultaneidades, os bois - e tudo aquilo que tais animais simbolizassem - ainda estivessem à frente do progresso, ao mesmo tempo que preparariam suas bases.

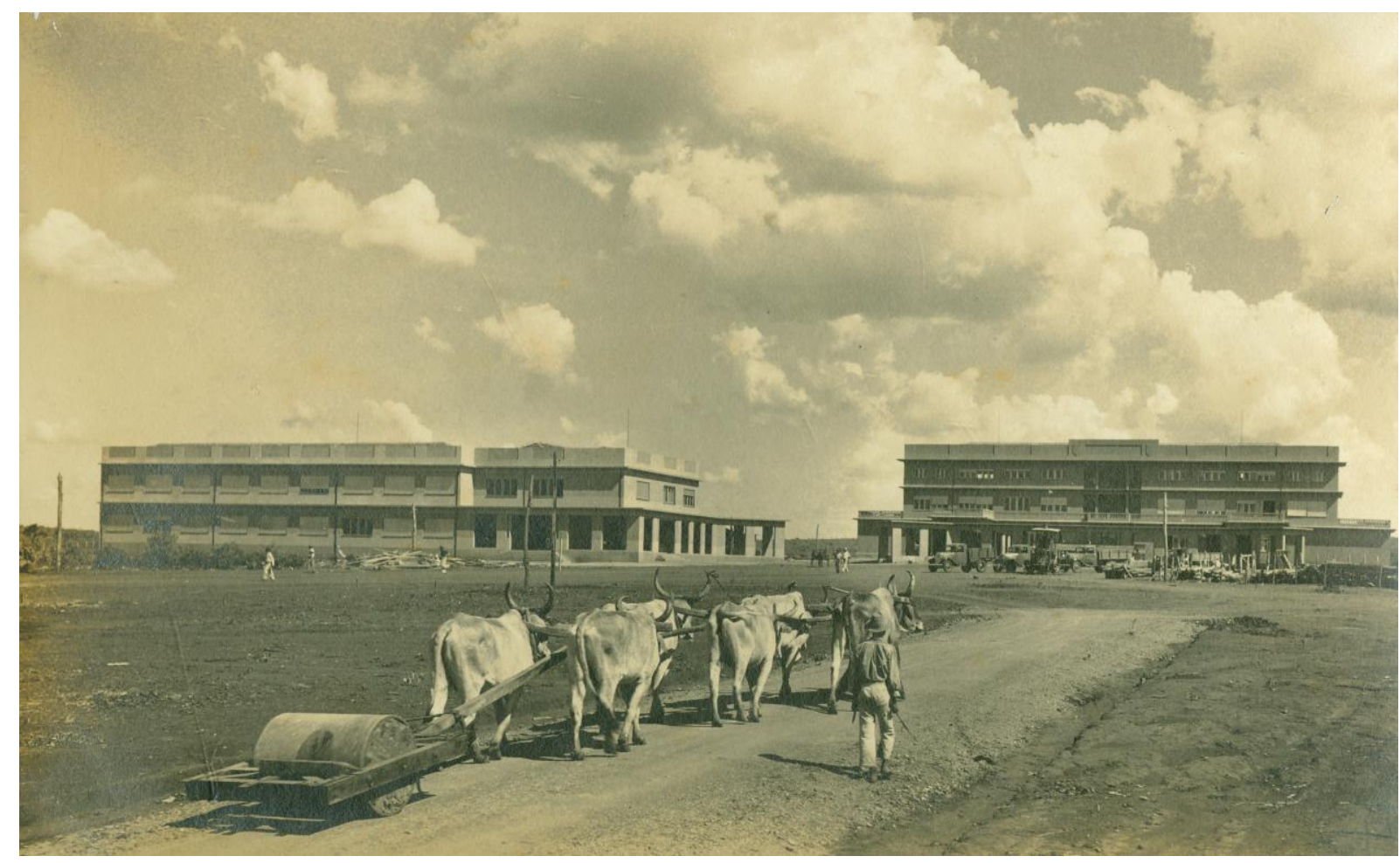

Figura 36: Carros de boi na Praça Cívica, 1936. Alois Feichtenberger. Goiânia-GO. Acervo MIS/GO.

Datada em 1936, a fotografia originalmente aparece no álbum Expedições ao norte, fruto da primeira passagem do austríaco pela região - o fotógrafo apenas se estabeleceria na capital goiana em definitivo na década de 1960 (FIGUEIREDO, S. H., 2003). Feichtenberger, aliás, neste lapso temporal cobriria como repórter de guerra as ocupações alemãs na Áustria e na Grécia, durante a Segunda Guerra Mundial. Além disso, também atuaria em outros locais do Brasil, como São Paulo, onde trabalharia como fotógrafo das Indústrias Matarazzo e ainda seria responsável por parte dos registros da capital paulista publicadas em São Paulo antigo, São Paulo moderno - um álbum comemorativo lançado às vésperas do quarto centenário da cidade. Essa capacidade de sintetizar dinâmicas locais apareceria no destaque ao intenso movimento e dinamismo da metrópole - enfatizados pelo fotógrafo através dos arranha-céus, do tumultuado tráfego de veículos e das multidões -, mas também na captura de acomodações igualmente presentes na capital paulista - como sugere o registro de obras no local da futura Avenida 9 de Julho, datada na década de 1930 e recuperado por Guilherme Talarico de Oliveira (2018). Essa perspectiva da "modernidade múltipla" comumente posta em evidência por Feichtenberger seria, segundo o autor, fruto do "choque" entre a realidade presenciada no país e a "manutenção dos padrões eurocêntricos de percepção de mundo" (OLIVEIRA, G. T., 2018). 
É curioso notar como a fotografia do carro de boi em frente ao Palácio do Governo se insere numa iconosfera mais ampla, transcendendo o objeto de estudo - o que naturalmente não significa afirmar que houvesse contatos diretos entre profissionais e produções, mas sim coincidentes olhares em ambientes que, mediante processos distintos, passavam por profundas transformações. Deste modo, conscientemente ou não, as dialéticas apareceriam quase como um temário próprio, habitando documentos fotográficos no Brasil e em outros países do mundo. Pode-se recuperar casos como de Lévi-Strauss que, aproximadamente em 1937 (por sinal, mesmo ano que o antropólogo visitara Goiânia), registraria, numa sequência de fotos, uma via do Bairro da Liberdade tomada por uma boiada. Os diálogos se dariam especialmente pela contraposição dos animais a uma dinâmica de progresso simbolizada pelos bondes elétricos. Não obstante, os bois em irrupção, ao contrário de Goiânia, pareciam entravar a modernidade, perturbando o fluxo dos bondes.

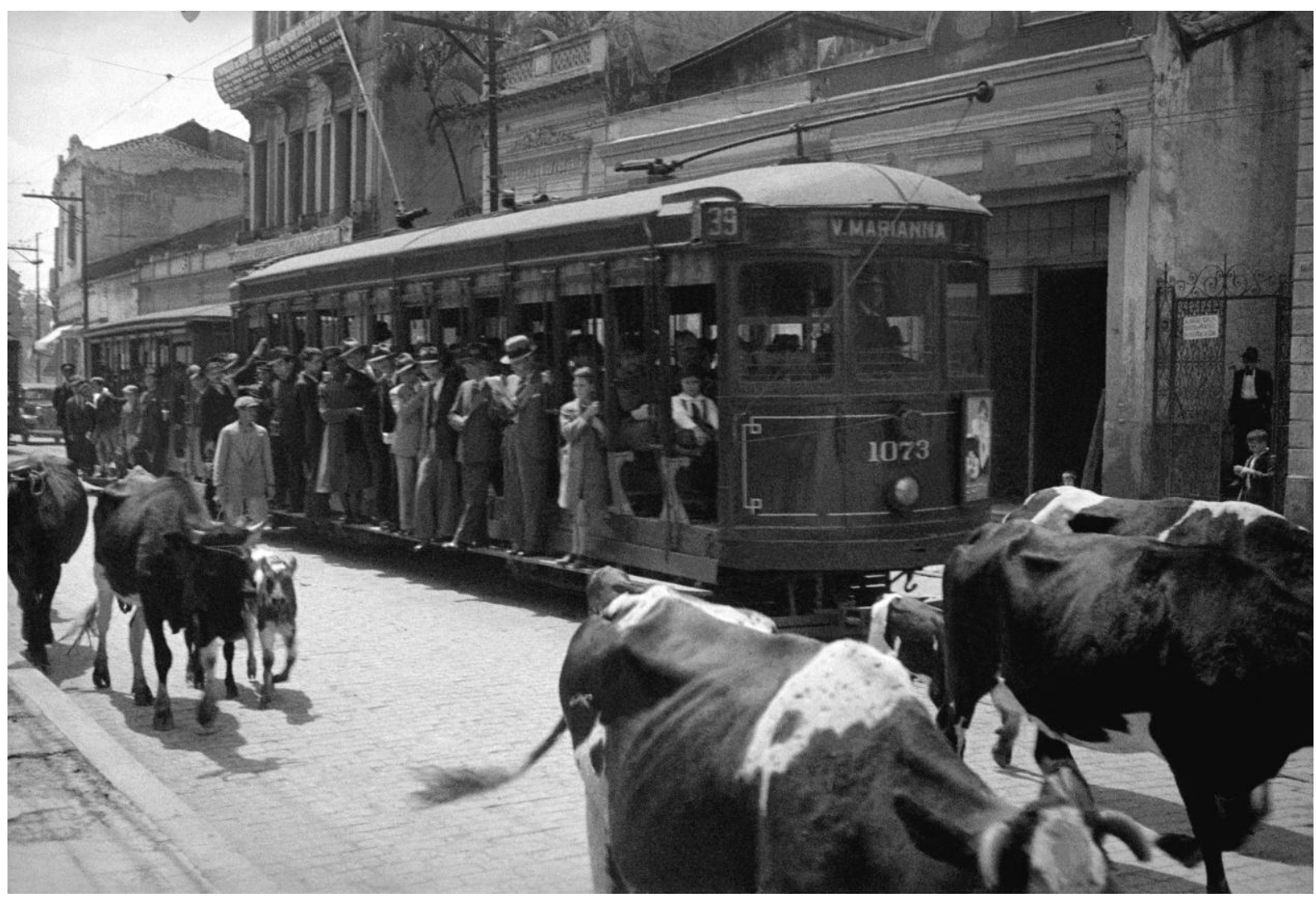

Figura 37: Rua da Liberdade, São Paulo, c. 1937. Claude Lévi-Strauss. Fonte: Acervo do IMS.

Semelhantemente à nova capital de Goiás, em outras fotografias, as supostas oposições se encerrariam num quadro permeado por obras em cidades novas - e onde as feições dos novos edifícios similarmente carregariam os signos da modernidade, com suas devidas particularidades geográficas e temporais. Em Washington, por exemplo, numa fotografia que retrataria o término da ala sul do prédio do Tesouro Americano (figura 38), um carro de boi - também em primeiro plano, porém pouco protagonista pelo enquadramento e 
altura de captura da foto - conviveria com a aura clássica da imponente edificação. Trata-se, no entanto, de uma foto datada em 1860, num contexto onde os veículos automotores eram raros e a tração animal era a principal força motriz. Já na década de 1950, numa foto de Chandigarh (figura 39), Ernst Scheidegger disporia o edifício do Secretariado, ainda em construção, ao fundo de um seco pasto tomado pelo gado em primeiro plano. Diante de um quadro que remeteria mais à tranquilidade da vida campestre do que ao movimento de uma cidade em construção (algo que daria não só pela presença dos animais e ausência de figuras humanas, mas também pela implantação da lâmina numa ampla área livre), o registro tomado por si só potencialmente despertaria dúvidas quanto ao estágio das obras - se de fato tratar-seia de uma empreitada em andamento ou se, na verdade, seria uma ideia abandonada. Todavia, numa Índia essencialmente rural, a dinâmica evocada pelo gado não seria gratuita - tanto que sua figura teria sido um elemento assimilado por Le Corbusier ${ }^{29}-$, sobretudo diante da sacralidade do animal no hinduísmo.

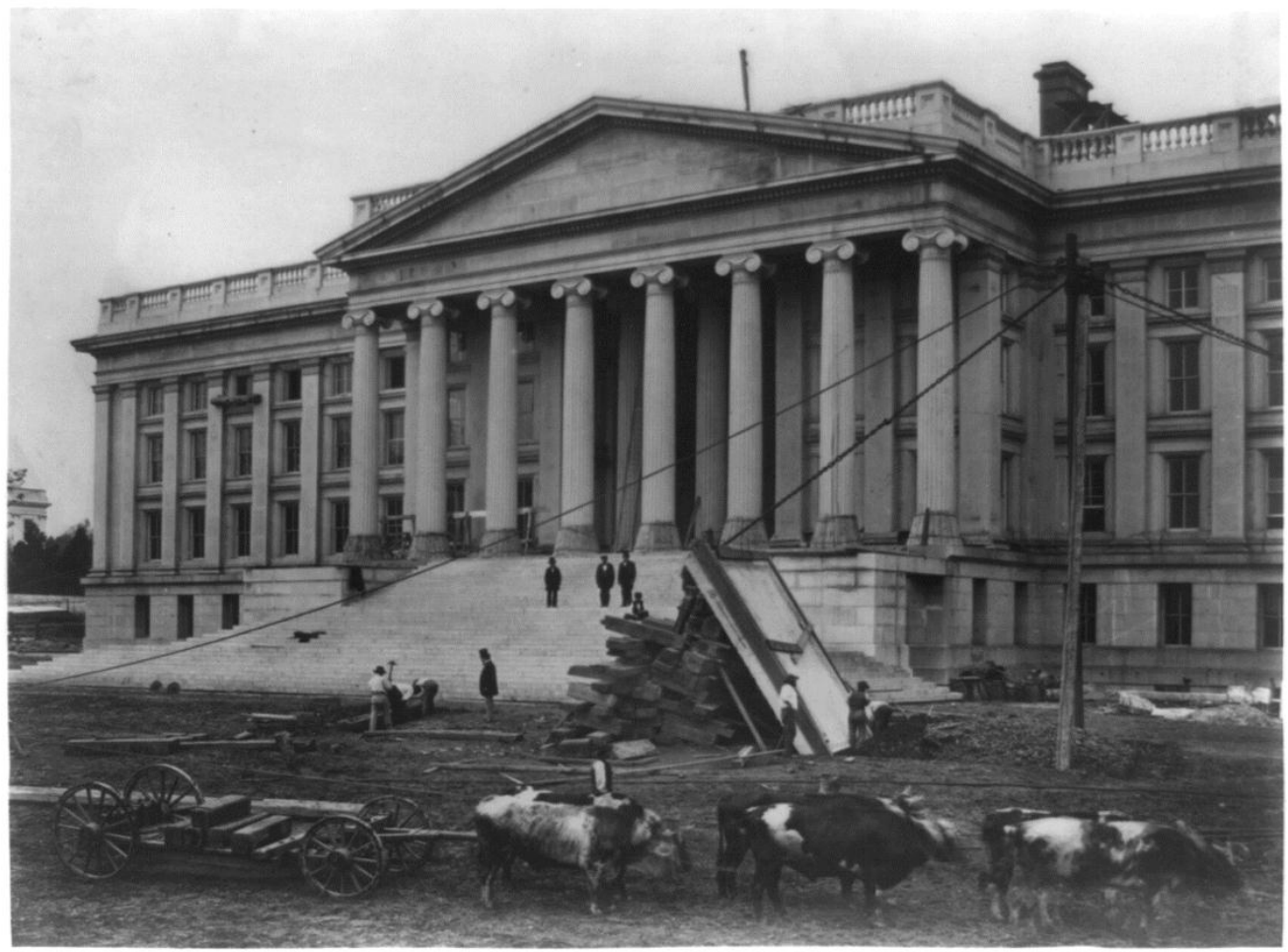

Figura 38: Construção do Tesouro Americano em Washington D.C., com bois em primeiro plano no lado sul. Lewis E. Walker. Fonte: Library of Congress/USA.

29 Claúdio José Pinheiro Villar de Queiroz (2010) aponta a presença de tais referências na concepção arquitetônica de edifícios de Chandigarh. Segundo o autor, na Casa do Governador, o elemento que coroa a cobertura "constitui o símbolo de força dos potentes touros indianos" (QUEIROZ, C. J. P. V., 2010, p. 49); no Palácio da Justiça, a cobertura/estrutura vistas a partir de um corte transversal sugeririam um "Y" que, realçado pelas extremidades superiores em curva, trariam o aspecto simbólico dos taureaux; e no Palácio da Assembleia, de modo flagrante, "a revelação decorre de contemplação da impressionante marquise que compõe o peristilo e dos recortes ou vazados nas colunas, mimetizando abstratas caras, olhos e bocas dos grandes bovinos que Le Corbusier desenhou e redesenhou, como se refletisse e acariciasse a própria Índia” (QUEIROZ, C. J. P. V., 2010, p. 49). 


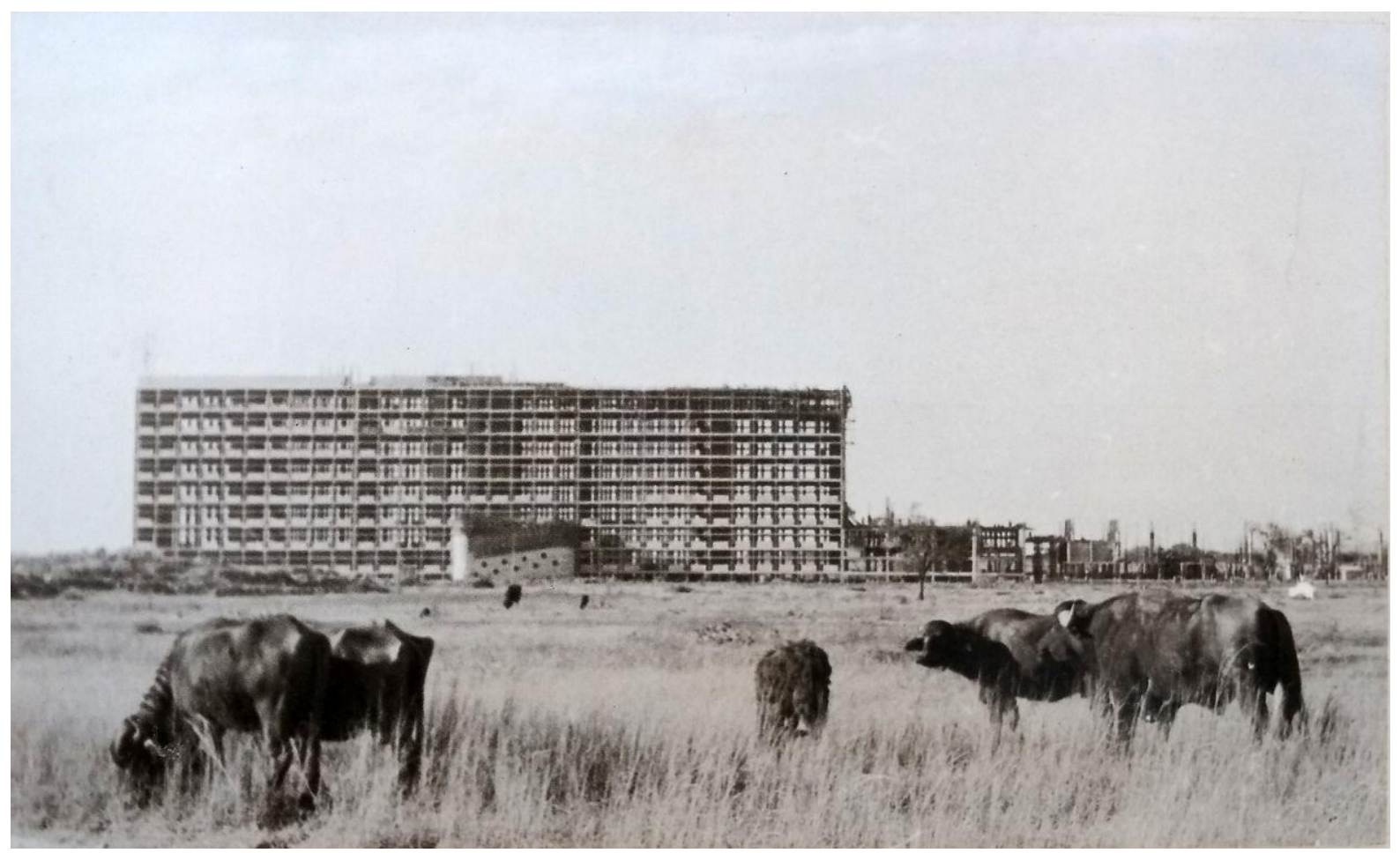

Figura 39: Secretariado de Chandigarh em construção. Ernst Scheidegger. Fonte: Moos e Scheidegger (2010).

Em síntese, de diferentes modos as representações do mundo rural e do mundo urbano num mesmo locus instigariam o imaginário mediante uma suposta antítese, à medida que correntemente "é significativo que a imagem comum do campo seja agora uma imagem do passado, e a imagem comum da cidade, uma imagem do futuro", como aponta Raymond Williams (1973/1989, p. 397) - ou ainda que "a ideia do campo tende à tradição, aos costumes humanos e naturais", enquanto a "ideia da cidade tende ao progresso, à modernização, ao desenvolvimento" (WILLIAMS, 1973/1989, p. 397). No entanto, ainda segundo o autor, este nexo pressupõe um sistema dicotômico - que ou desconsideraria o presente ou o imergiria num tensionamento - e, ao invés de simplesmente apreender imagens do campo e da cidade como contrapostas, é preciso vislumbrar a existência de interrelações, sobretudo diante de zonas de fronteiras (econômicas, sociais e culturais).

A adaptação dessas ponderações subsidiaria articular as imagens das coexistências como chaves de leitura da construção de Goiânia, de maneira que as acomodações nem sempre apareceriam como elementos contrários ao engendramento da aura de modernidade, mas marcariam o outro lado de uma mesma moeda no curso de um amplo processo conquanto as rememorações também pressuponham esquecimentos, como veremos adiante. Nesse sentido, seria expressiva a forma que a fotografia de Feichtenberger se replicaria em vários outros álbuns e publicações contemporâneas à gênese da cidade - como no Álbum de Goiaz e mesmo no Álbum de Fotografias sobre o Planejamento e Construção da Cidade de 
Goiânia - e posteriormente, para além das estremas temporais que balizam esta dissertação, mediante ressignificações: a fotografia sinalizaria a mediação de uma conjuntura permeada por uma "modernidade possível" (GONÇALVES, 2002), uma expectativa baseada no horizonte de uma modernidade iminente e, com o avançar das décadas, uma modernidade alegadamente lograda. Entende-se, portanto, que a ampla reverberação do registro se daria por sua capacidade de sintetizar as amálgamas que matizariam toda a gênese de Goiânia. Representaria ainda o ponto de inflexão que se conformava com a concretização da nova capital: sobre as raízes de um estado de parcos recursos, se operariam transformações estruturais com os meios possíveis, num gesto de nuances miraculosas - como sugeriria Inês Piacesi, atribuindo o feito ao interventor.

Há, no entanto, um outro Pedro que veio desbancar o grande feito de Cabral, agora em pleno século XX. É o homem que descobriu o modo de fazer milagres. De um velho Estado, eternamente primitivo, esquecido e quase nulo, ele tirou um mundo novo e, dentro dele, fez emergir a tradição de um Povo, e a ressurreição de uma causa perdida - Goiânia. É a metempsicose dos gênios: Goiaz renasce na "criança" admirável e perfeita que é Goiânia. (PIACESI et al., 1943, p. 6)

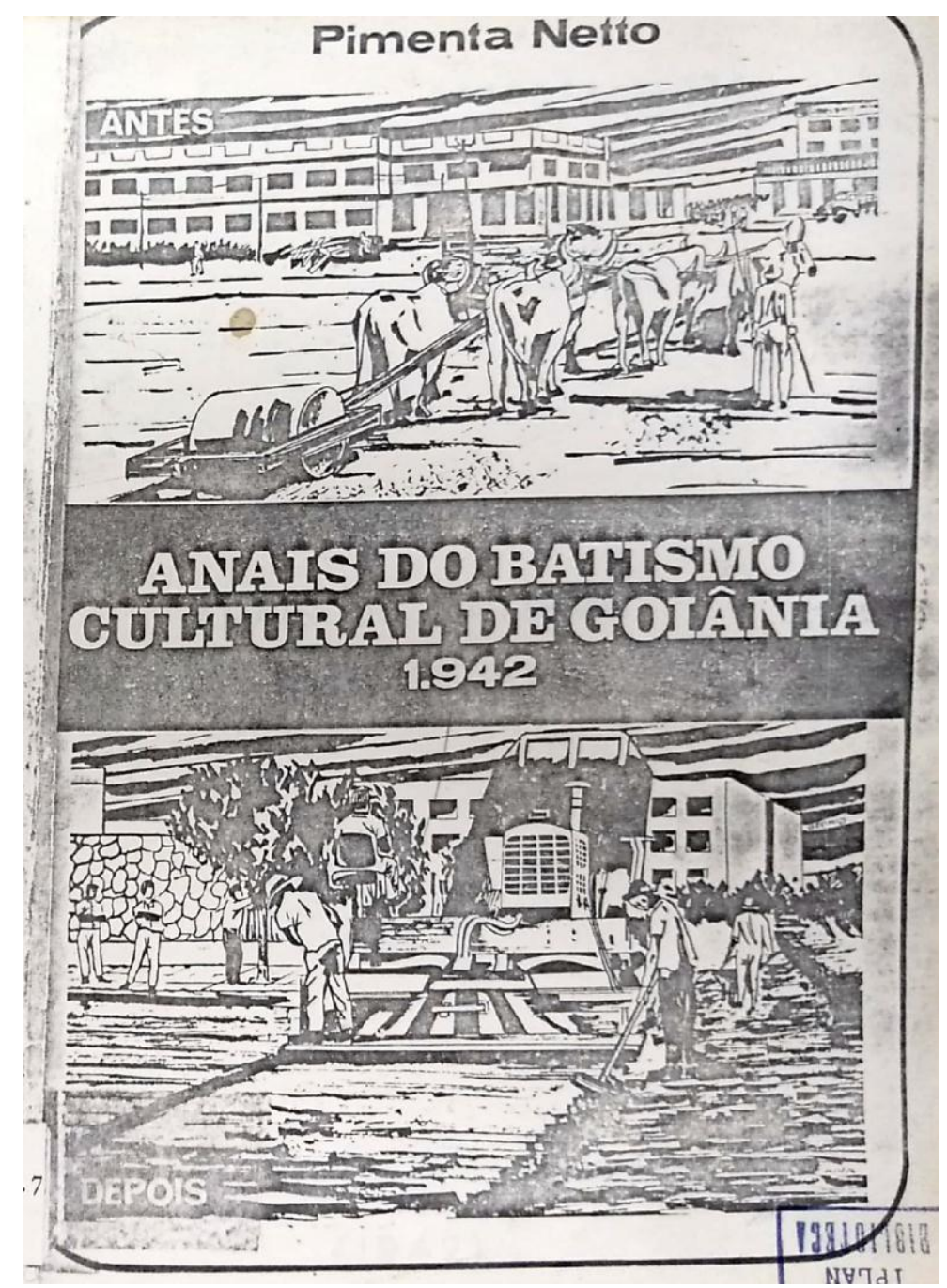

Figura 40: Capa da obra Anais do Batismo Cultural de Goiânia. Fonte: Netto (1969)/Acervo da SEPLANH. 

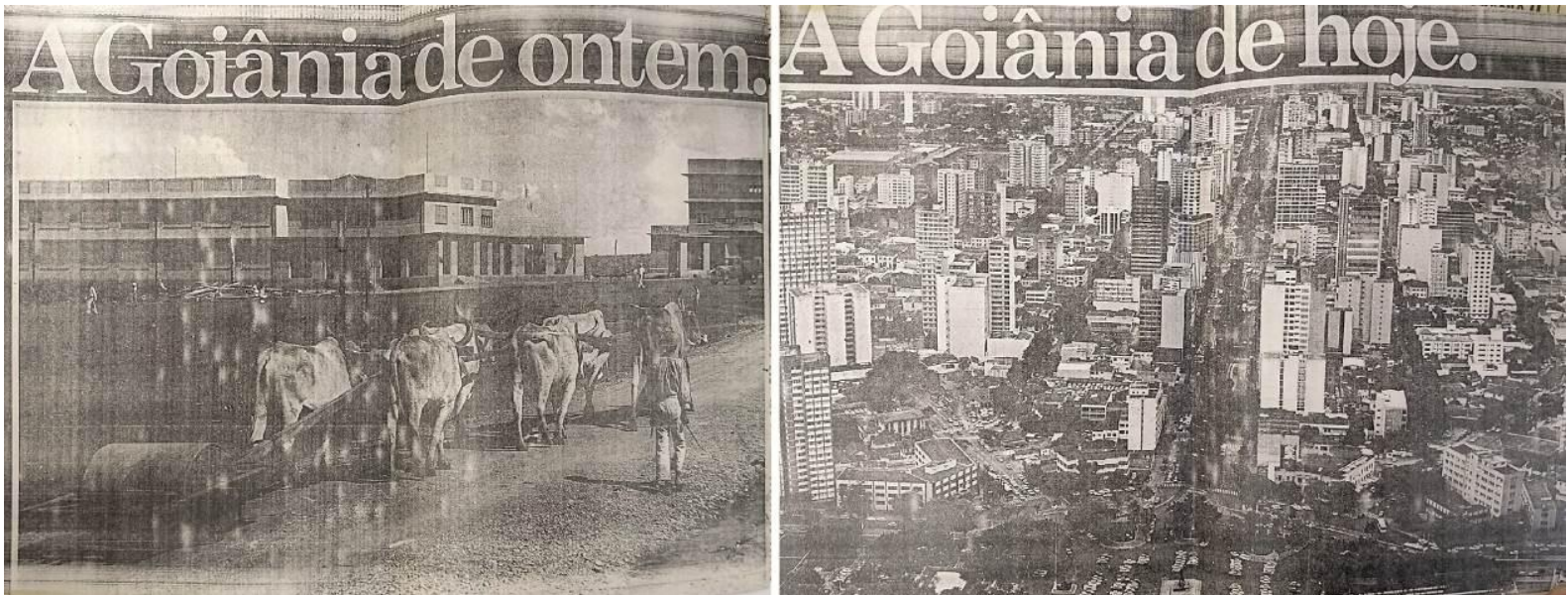

Figura 41: Peça publicitária em jornal, c. década de 1980. Fonte: Acervo da SEPLANH, modificado pelo autor. 


\section{Cidade-concretude}




\section{CIDADE-CONCRETUDE}

\subsection{Notas sobre as dialéticas na nova capital}

Goiânia não é a cidade populosa, não é o arranha-céu que não tem, não é o luxo dos salões, não é a receita pública fabulosa, nem tampouco os cassinos que porventura queiram ver. É uma grande ideia na vida nacional, é um símbolo. Conseguiu chamar a atenção de todos os brasileiros para a magna questão das potencialidades econômico-sociais das nossas zonas mediterrâneas. (COSTA, G. C., 1942, p. 3)

Civilização, beleza e progresso. Com esses três substantivos, uma montagem de página dupla no periódico carioca Revista da Semana indicaria o que se apreenderia em Goiânia, a nova capital que, cada vez mais, assumia-se como tal. As fotografias, contumazes na revista e cuidadosamente escolhidas para a composição, contribuiriam para corroborar o que se enunciava: as linhas "modernas" de edificações como o Palácio do Governo, o CineTeatro Goiânia, o Automóvel Club, o Mercado Público e até a sede do jornal O Popular; o tratamento paisagístico nas avenidas e praças da cidade, marcado pela topiaria, pelo ritmo de uma vegetação ainda diminuta e pelas fontes luminosas; o Lago das Rosas, balneário de praia artificial com sua famosa balaustrada e trampolim de inspirações Art Déco (esse último ainda em construção); tudo isto sinalizaria o sucesso da empreitada, que apareceria quase como se apreciada pelo olhar imóvel do interventor, num busto que traria a inscrição "Doutor Pedro Ludovico Teixeira, o arquiteto de Goiânia”.

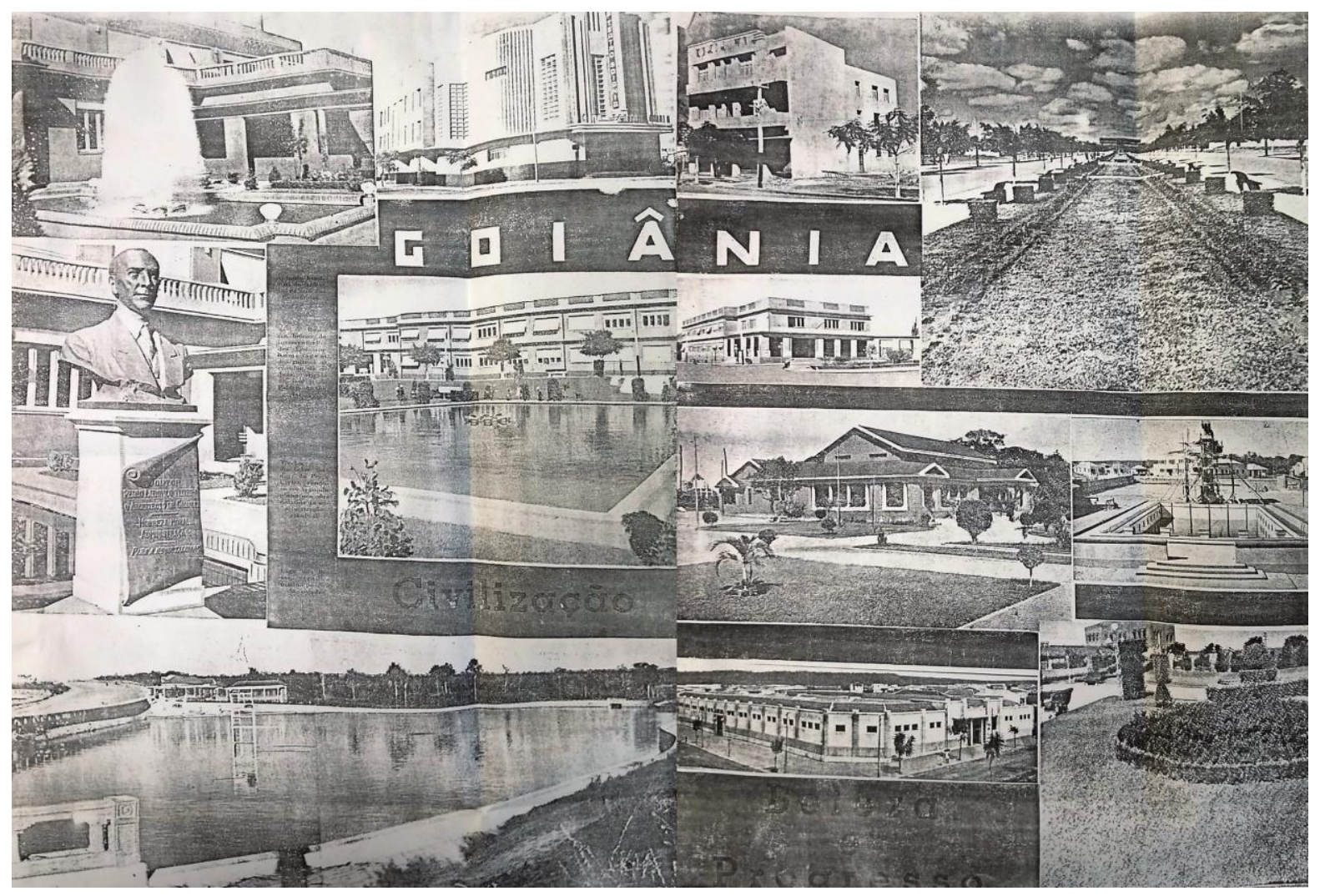

Figura 42: Montagem de Goiânia. Autoria desconhecida. Fonte: Revista da Semana (1942)/Acervo da SEPLANH, modificado pelo autor. 
O estado de concretude em princípio confirmaria as expectativas que permeavam as concepções da cidade-ideia - embora a concretude não necessariamente implicasse na integralidade de um processo de estabelecimento, uma vez que o próprio Pedro Ludovico Teixeira (1973, p. 196) compreenderia que "uma cidade [...] se constrói, se completa, com o perpassar dos séculos e das gerações”. A modernidade, engendrada em meio aos discursos, se delinearia não mais somente a partir do campo retórico, mas igualmente acompanhada de transformações materiais no bojo de uma modernização que, sobrepujando-se aos sinais de progresso já presentes em Goiás, se manifestaria em Goiânia de forma privilegiada.

Deve-se recordar, contudo, que em que pese a contínua existência de ambivalências, haveria narrativas que associariam a modernidade à nova capital e especialmente a partir de um nexo referencial e binário, de modo que parte da aura moderna atribuída a Goiânia se condensaria mediante uma intrínseca relação de oposição à antiga sede administrativa. Tal contraste, por sua vez, não seria estanque, à medida que ora se basearia na depreciação da Cidade de Goiás, acentuando um movimento de ruptura, ora se centraria no estabelecimento de uma continuidade cordial - sobretudo num segundo momento em que, com o avanço da construção de Goiânia, intentava-se pacificar a animosidade entre os habitantes das duas capitais (ARRAIS, 2013) -, onde uma seria a guardiã das tradições goianas e, a outra, o exemplo do arrojo ou o prenúncio do porvir.

Se as pessoas que vem a Goiás se interessam, inicialmente, por ficar conhecendo
Goiânia, que é o índice da evolução social, presente e promissora, desta unidade da
República, manifestam-se invariavelmente desejosas de conhecer também a cidade
de Goiás, a velha Vila Boa, às margens do lendário rio Vermelho - que em dois
séculos foi a capital da capitania, da província e depois do Estado de Goiás e onde
cada rua, cada recanto e cada edifício, em estilo barroco ou em simples estilo da era
colonial, nos falam da pujança econômica da região nos tempos em que viveram os
mineradores de ouro. Na antiga cidade estão quase todas as nossas relíquias
históricas. (O VALOR..., 1944)

Sem adentrar na discussão que a noção de tradição é uma criação própria da modernidade (GIDDENS, 1999/2002), o estabelecimento de um vínculo de caráter antitético sinalizaria um dos prismas inscritos no termo moderno que, conforme incursionaria Patetta (2008/2012, p. 99), “se tornou importante e problemático quando apareceu o termo antigo, ou ainda quando vieram a se precisar a categoria e a concepção do antigo". Diante dos contrapontos, ressalta-se a presença de uma operação narrativa onde, no jogo de discursos, o espaço e suas representações não seriam apenas sintomáticos, mas agentes ativos.

A sequência das pranchas do Álbum de Fotografias sobre o Planejamento e Construção da Cidade de Goiânia, por exemplo, é capaz de revelar, mediante uma oportuna disposição dos registros, a intenção de reforçar distanciamentos. Fotografias de prédios 
públicos de Goiânia, concebidos para abrigar órgãos administrativos, seriam apresentadas imediatamente antes ou depois de fotografias de edifícios-sede desses mesmos órgãos anteriormente situados na Cidade de Goiás. Uma vez que a arquitetura também é representação, saltariam aos olhos as distinções entre os traços coloniais ou ecléticos presentes na "velha capital" (e essa é exatamente a expressão utilizada ao longo do álbum), que remeteriam à vetustez, e as feições hodiernas de volumes escalonados e linhas sóbrias exibidas na nova cidade, signos de progresso. A modernidade, destarte, se estruturaria sobre o lastro das antinomias.
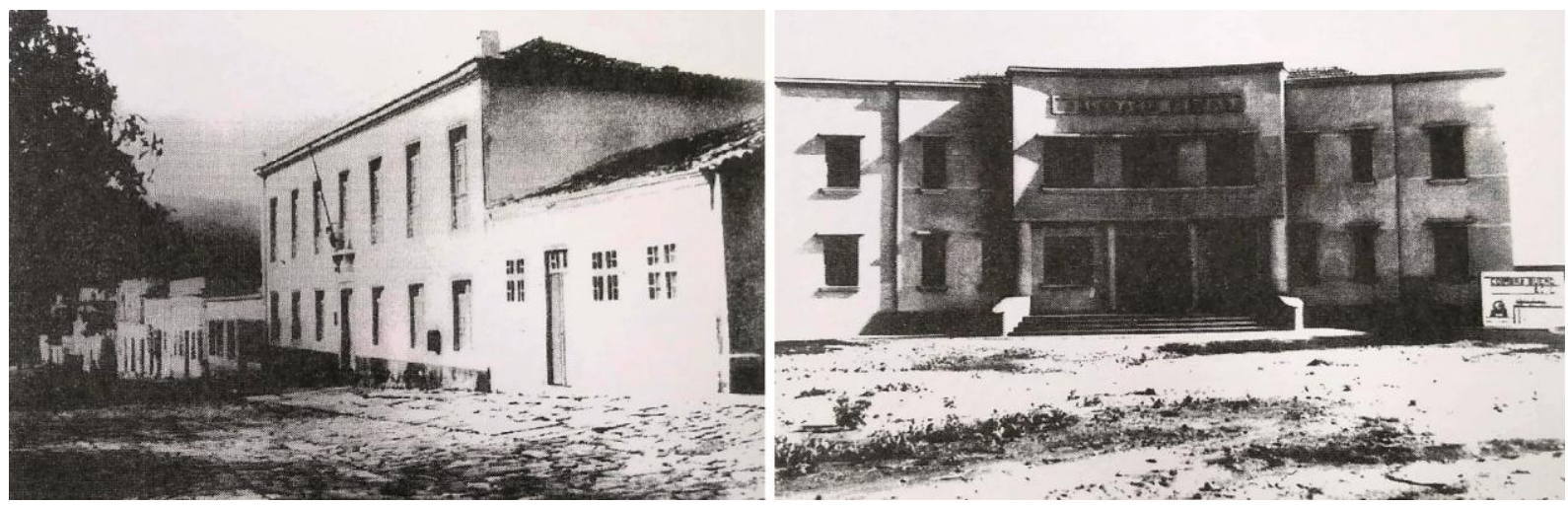

Figura 43: Edifícios da Delegacia Fiscal em Goiás e Goiânia, respectivamente. Autoria desconhecida. Fonte: Neto (1937/1995)/Acervo do Museu da Imagem e do Som de Goiás, modificado pelo autor.

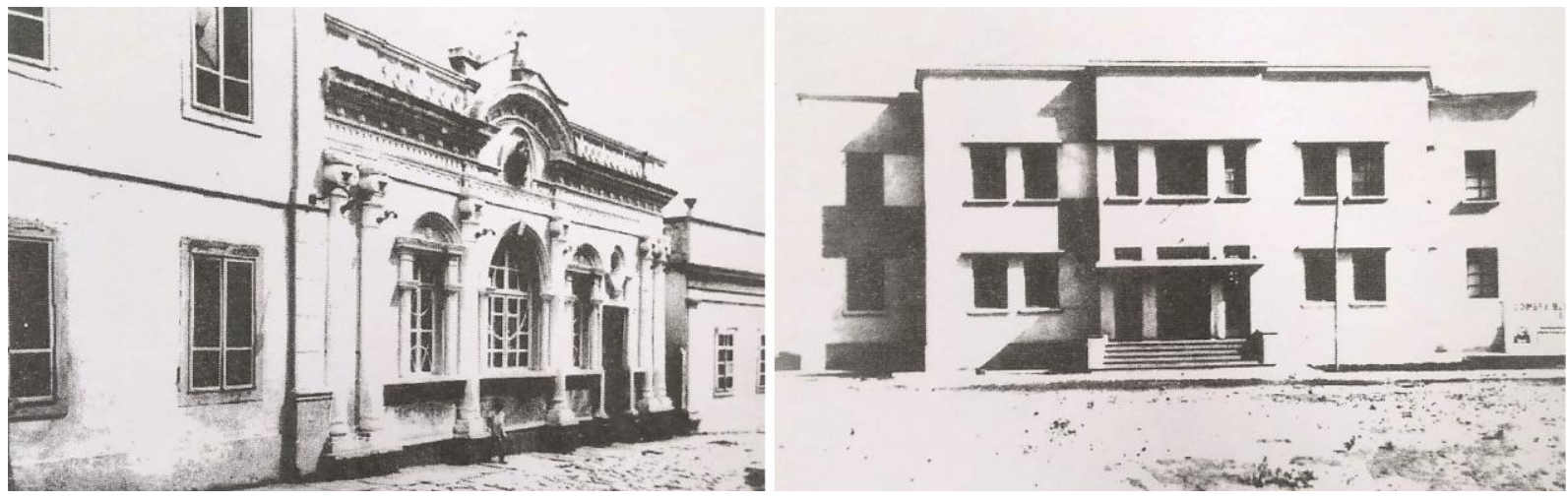

Figura 44: Edifícios do Juízo Federal em Goiás e Goiânia, respectivamente. Autoria desconhecida. Fonte: Neto (1937/1995)/Acervo do Museu da Imagem e do Som de Goiás, modificado pelo autor.

A construção de dicotomias como novo/velho ou progresso/tradição se apresentaria de modo multiforme e também se deslocaria para os pares cidade/campo e moderno/arcaico, como já pôde-se observar até aqui, e é possível reiterar a existência de uma lógica antagônica ainda se atendo ao Álbum de Fotografias sobre o Planejamento e Construção da Cidade de Goiânia - onde a foto do burro de carga apresentada no capítulo anterior demonstraria, segundo sua legenda, como era o transporte na velha capital, enquanto fotografias posteriores estampariam um avião da VASP em Goiânia, em meio a engravatados homens e muitos curiosos. Já no Álbum de Goiaz, ou em publicações como a Revista Oeste, tomadas urbanas 
contrastariam com imagens de grandes rebanhos ou robustos zebus em zonas rurais - e nestes casos não necessariamente apareceriam dispostas de forma negativada, mas apresentadas em referência à pujança econômica do estado ${ }^{30}$.

Todavia, as narrativas como via para incorporação da memória ao engendramento de identidades, segundo Ricoeur (2000/2007, p. 98), se dariam mediante uma operação de caráter seletivo, onde se ofereceria "à manipulação a oportunidade e os meios de uma estratégia engenhosa que consiste, de saída, numa estratégia do esquecimento tanto quanto da rememoração". E se isto apareceria nas celebrações dos atos fundadores - fundação da nova capital e inauguração oficial da cidade que, por sua vez, fariam alusões às datas na égide da Revolução de 30 -, igualmente se desvelaria através do jogo retórico que, em essência, procurava vincular Goiânia a tudo que fosse moderno e, por dedução, colocar noutro polo (por vezes obscurecido) as facetas que não fossem convenientes à imagem que pretendia-se consolidar - conquanto, em última instância, pudessem aparecer ligadas à nova capital como indícios de um estado de vicissitude. Nesse sentido, as múltiplas intencionalidades em geral permeariam a manutenção de certa coesão na linha discursiva que designaria Goiânia como indiscutível símbolo de progresso - o que Luciano Silva (2014) classificaria como "narrativas utópicas".

Um elemento basilar que ajuda a elucidar essa lógica diz respeito à difusa propaganda criada em torno de Goiânia, por meio dos diversos veículos de comunicação - e, não por acaso, a abertura deste capítulo se dá com a composição da Revista da Semana. Sem perder de vista que a origem dessas iniciativas, em princípio, se daria através da orientação de Armando de Godoy no relatório encaminhado a Pedro Ludovico, lembremo-nos que, dentre as principais motivações das campanhas, se situaria a premência de atrair capital e habitantes para a região. Assim, com fotografias, projetos, mapas ou frases de efeito (como no célebre cartaz que traria a inscrição "Enriqueça 4 vezes mais adquirindo lotes na nova capital”), podese dizer que as propagandas de fato teriam efetividade e por meio delas, muitos dos pioneiros teriam conhecimento da empreitada e decidiriam se aventurar na cidade que surgia - como nos casos do fotógrafo Eduardo Bilemjian e do a princípio servente de pedreiro Pedro Meireles.

\footnotetext{
${ }^{30}$ Deve-se considerar ainda que determinadas demandas a fotógrafos advinham de fazendeiros que procuravam registrar e divulgar suas terras e gados, o que motivava a confecção e eventualmente a inclusão destas fotografias em publicações. Benito Bianchi (2000), um dos fotógrafos pioneiros de Goiânia, participara de um álbum sobre o Triângulo Mineiro organizado por Orlando Barbosa, nos moldes do Álbum de Goiaz, e afirmaria que tal serviço teria sido custeado por ruralistas que, por sua vez, teriam seus animais apresentados nas páginas da obra. Similarmente, Dalmo Teixeira (2002), filho de João de Paula Teixeira Filho, relataria a demanda por fotografias de gados em Minas Gerais, onde o pai tinha que tomar certas precauções como não tirar fotos perto de cercas ou não misturar bois, vacas e cavalos.
} 
Um dia, vi fixado, na Estação da Luz, em São Paulo, uma planta da nova capital do estado de Goiás, a qual me chamou a atenção. Disse: "Liberta, isso é o lugar de futuro, vamos para lá". Fiquei com esse pensamento na ideia. Acabada a Revolução de 32, em São Paulo, resolvi mudar para a nova capital do Estado de Goiás, que estava em construção [...] (BILEMJIAN apud TELES, 1986/2012, p. 87)

Viajei para Goiânia, convencido por uma propaganda que o Dr. Pedro Ludovico mandou publicar nos rádios. E eu, como um tanto aventureiro, procurei vir para Goiânia. Saí de Floriano no dia 16 de junho e cheguei aqui no dia 07 de julho de 1939, em Anápolis. Aí, procurei vir para Goiânia o mais rápido e o serviço que encontrei para mim foi ser servente de pedreiro nas obras da capital de Goiás, o que fiz com muita satisfação. (MEIRELES apud GOIÂNIA, 1985, p. 146)

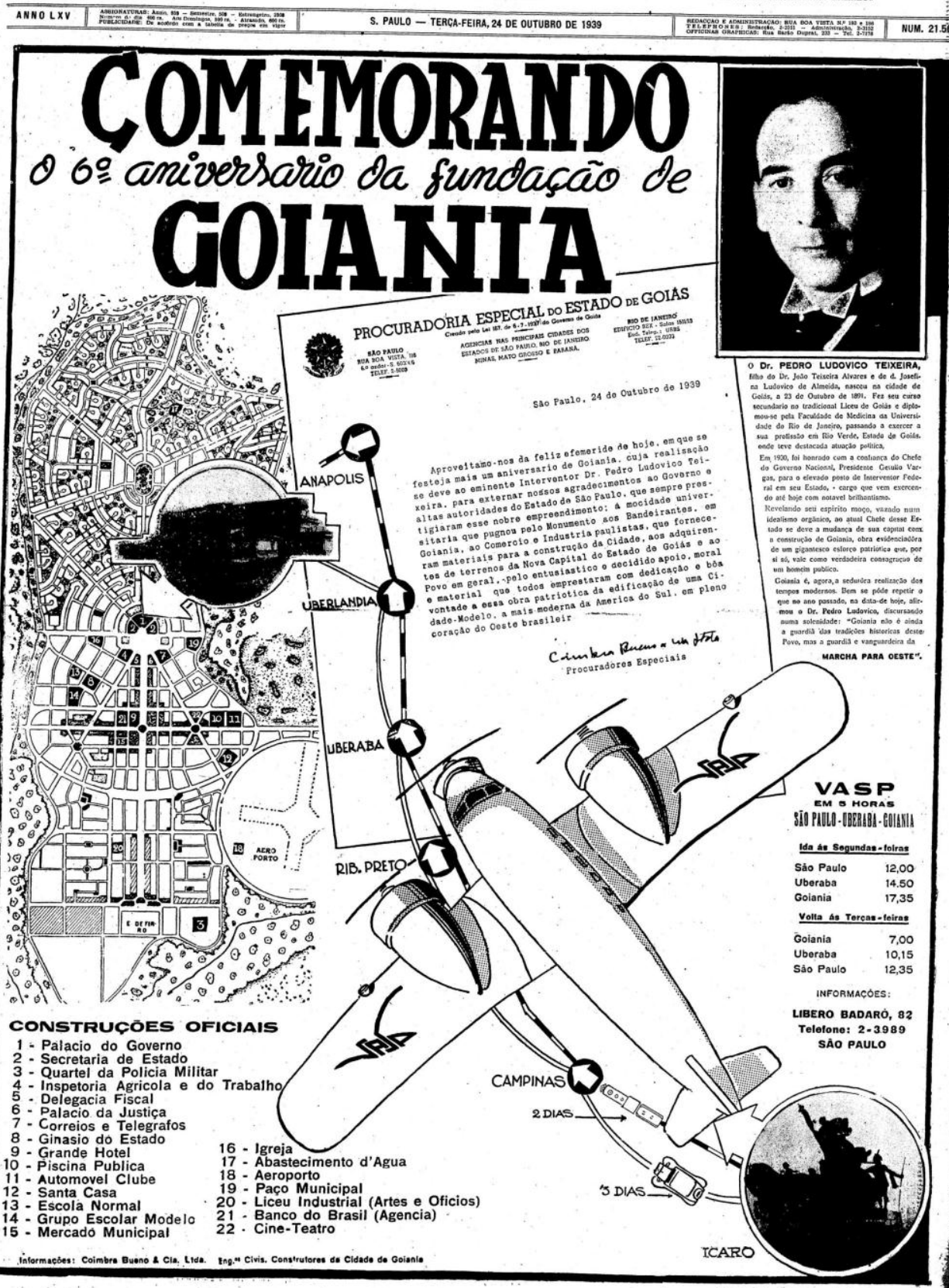

Figura 45: Exemplo de divulgação em capa de jornal datado de 24 de Outubro de 1939. Autoria desconhecida. Fonte: O Estado de S. Paulo (1939). 
Por outro lado, a atratividade de investimentos e população a Goiânia e a Goiás não se daria exclusivamente através da difusão do empreendimento e do estado, mas também passaria pelo empenho na reversão de longínquas imagens estigmatizadas cujos efeitos transitariam entre a indiferença e a negativação. Os engenheiros Coimbra Bueno, em relatório, revelariam a dificuldade de se realizar negócios diante das variadas referências pejorativas de Goiás e, como saída, clamariam pela intensificação das propagandas. Não coincidentemente, os irmãos seriam um dos grandes agentes divulgadores da construção da nova cidade - o que também derivaria de outras razões - e Aberlado até chegaria a integrar a Comissão de Divulgação de Goiás, criado em 1935 por Pedro Ludovico para auxiliar o Departamento de Propaganda e Expansão Econômica do Estado em ações fora de Goiás.

Estamos constantemente vendo o nome do Estado fora dele, em referências pouco
recomendáveis, e não podemos deixar de lamentar fatos assim, cujas consequências
ressentimos na dificuldade de aquisição de materiais. [...] "GOIÁS EXISTE?" foi a
pergunta irônica que inúmeras vezes ouvimos nas repartições federais e nos meios
comerciais de S. Paulo e do Rio de Janeiro, quando tratando de interesses do Estado.
[...] Por várias vezes tivemos a oportunidade de procurar interessar capitalistas em
negócios aqui, que fariam incrementar nosso progresso e, sem nos prevalecermos de
nenhum atributo oficial, quando apenas transmitíamos informações de caráter
inteiramente particular, sondamos vários capitalistas que se limitam a realçar uma
série de dificuldades mostrando-se desinteressados; em todos estes entendimentos
ressaltamos a necessidade de maior e mais intensa possível, a propaganda do Estado.
(COIMBRA BUENO \& CIA LTDA., 1936 apud MONTEIRO, O. S. N., 1938, p.
454)

Alvares (1942, p. 45), na legenda de um registro onde Joaquim Câmara Filho entrevistava Abelardo Coimbra Bueno, afirmaria que "Goiás tornou-se divulgado com a realização de Goiânia”. A assertiva é sintomática e, diante do questionamento à memória da decadência e do atraso, Goiânia seria, na condição de grande vitrine do estado, o símbolo de um novo tempo que se enunciava. Urgia, portanto, desde o princípio, projetar sobre a nova capital as imagens que Goiás visava incorporar, o que eventualmente implicava em hiperbolismos discursivos. Gerson de Castro Costa, numa entrevista enquanto diretor-geral do Departamento Estadual de Imprensa e Propaganda, sinalizaria, pelo menos parcialmente, a razão e importância desta sobeja tônica.

Como é sabido, no início da edificação de Goiânia, tínhamos necessidade de uma divulgação intensa, contundente, chocante, - em busca da qual se lançava mão de todos os meios, trazendo alguns, aparentemente, efeitos contraproducentes. Mas é verdade que precisávamos pôr o nome de Goiás no cartaz, a todo custo, considerando que éramos um Estado completamente obumbrado por uma nuvem secular e pesada de indiferença perante as demais unidades federativas, a despeito de suas enormes possibilidades econômicas até então inteiramente desconhecidas. (A PROPAGANDA..., 1944, p. 17)

Naturalmente não se minimiza o espectro político de parte desses discursos, como ferramenta de reafirmação em escala local - sobretudo diante das disputas entre mudancistas e 
antimudancistas - e nacional - prefigurada pela Marcha para o Oeste, onde Goiânia seria uma realização primal. Na verdade, trata-se de uma relação de limites fluídos, onde Estado e imprensa (ou, mais amplamente, agentes de produção cultural) flertariam especialmente com o advento do Estado Novo - como sugere o coquetel na presença de Herbert Moses, o financiamento estatal da Revista Oeste e a ampla difusão das notícias de Goiás expedidas pelo Departamento de Propaganda e Expansão Econômica do Estado, como relevaria um relatório de Câmara Filho ao Diretor Geral da Fazenda.

A propaganda deste Estado vem sendo recebida com prazer pela imprensa de todo o
país. Daí o destaque dado pela mesma aos comunicados que a ela envio, bem assim
os constantes e inúmeros pedidos de jornais e revistas que querem colaboração. Tem
esse departamento recebido, de pessoas notáveis da imprensa e da literatura,
congratulações epistolares, pelo modo como vem sendo feita a ressurreição da nossa
terra, esquecida e abandonada outrora. [...] Iniciei o serviço distribuindo
comunicados a 45 jornais. Hoje, porém, há dias distribuo a 150 jornais e revistas. É
desejo meu aumentar esse número para 200, sem mais delongas. (CÂMARA
FILHO, 1936 apud MONTEIRO, O. S. N., 1938, p. 190)

Diante da necessidade de colocar Goiás e Goiânia em evidência, a divulgação chocante mencionada por Castro Costa por vezes se valeria de artifícios singulares. Em 1936, por exemplo, se veicularia a informação que Goiânia seria uma cidade tão moderna que, ao invés de cemitério, teria apenas forno crematório, com o argumento de que "o cemitério, de acordo com os preceitos do urbanismo, não diz bem as condições de higiene de uma cidade moderna" (GOYANIA..., 1936, p. 3). A notícia, que causaria bastante furor, não seria necessariamente verídica e numa das matérias que trariam tal informação, publicada no jornal carioca Correio da Manhã, percebe-se que o impactante chamariz seria na verdade uma estratégia para publicitar Goiânia. Contiguamente, se sedimentaria sua imagem de progresso, seja textualmente - ao reiterar que a cidade "reflete pelos seus traços de elegância arquitetônica o que existe de mais moderno em matéria de urbanismo [...] pela mão de um dos técnicos de maior reputação nacional" (GOYANIA..., 1936, p. 3) -, seja visualmente - ao trazer uma tomada parcial da região onde se construíam as casas para os funcionários, pressupondo um núcleo plenamente estabelecido. O mineiro Pedro Osório, que atuara como secretário do Departamento de Propaganda e Expansão Econômica do Estado, posteriormente confirmaria o propósito.

Câmara Filho era um jornalista muito carismático. Ele fazia muitas correspondências, até fantasiosas, aos jornais do País, visando fixar Goiânia e atrair gente para cá. Ele escreveu primeiro sobre o crematório. Dizia que Goiânia, como cidade moderna, não teria cemitério, mas um crematório, e para isso o governo estava fazendo estudos para implantá-lo. Isso provocou a imediata reação da Igreja, e o bispo Dom Emanuel, que era da Comissão da Fundação de Goiânia, veio imediatamente em nome do Núcleo Apostólico protestar. O Brasil, sendo um País católico, não ficava bem, protestou o bispo. Câmara Filho se desculpou, dizendo que 
fizera o artigo somente para fixar o nome de Goiânia, porque ao referir-se à nova capital, todo mundo só falava em Campininha, desconhecendo Goiânia. (OSÓRIO apud TELES, 1986/2012, p. 227)

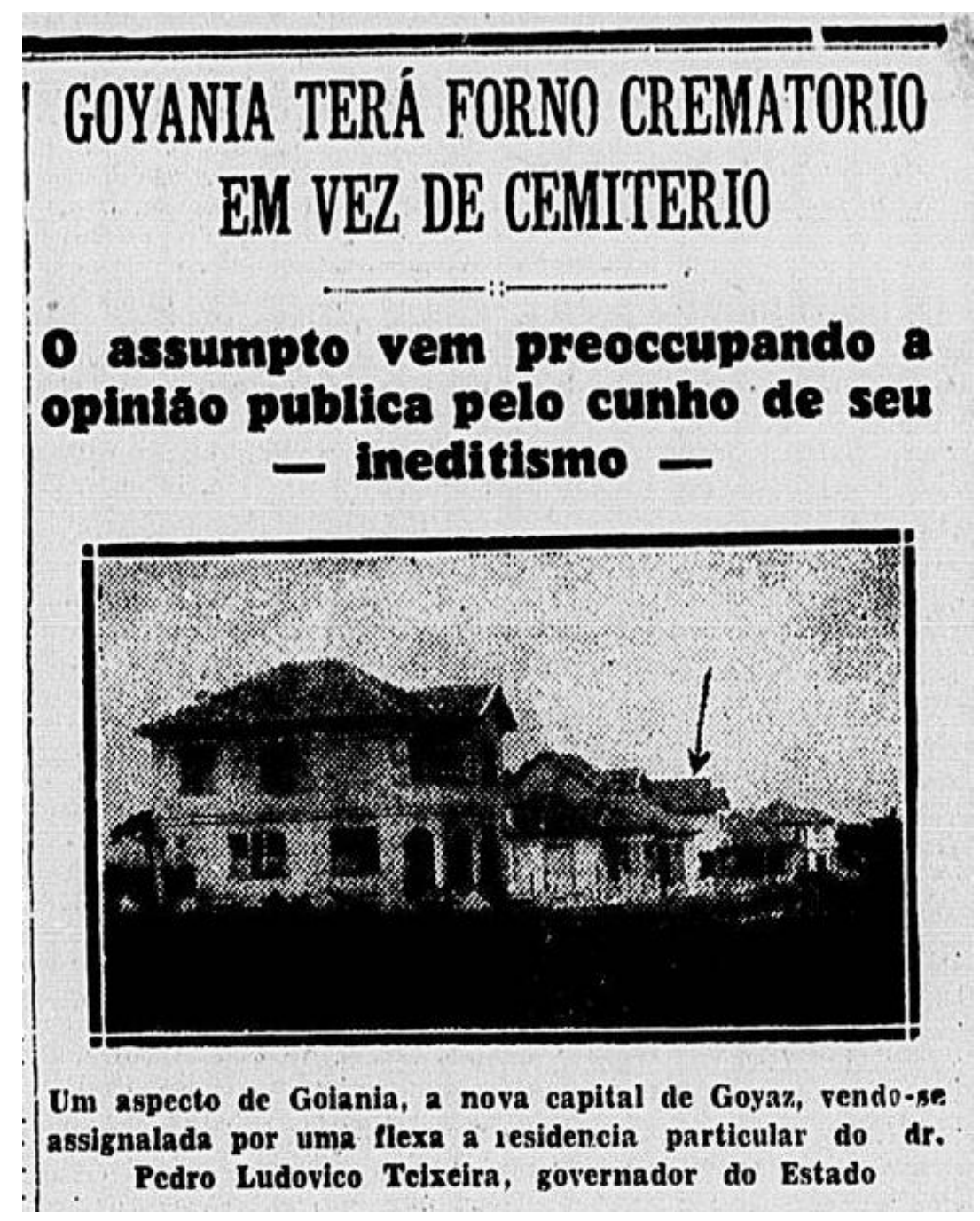

Figura 46: Parte superior da reportagem sobre o crematório. Autoria desconhecida. Fonte: Correio da Manhã (1936).

Se esse caso excepcional contribui para desvelar algumas das dinâmicas presentes na constituição de narrativas que, por sua vez, contribuiriam para o engendramento de uma nova identidade, essencialmente moderna, é importante reiterar que a identidade não é fruto do acaso, mas do esforço. Em meio aos embates simbólicos que permeariam o processo, o empenho no fechamento identitário pressuporia lançar mão do fechamento da narrativa, como sinaliza Ricoeur (2000/2007), com suas seleções, destaques, cortes e bricolagens. Nesse sentido, é possível compreender algumas das lógicas que motivariam a (re)produção de discursos e práticas ao longo da gênese de Goiânia, exemplificadas pela tônica de parcela da imprensa.

Entretanto, num quadro onde a cidade e suas representações se produzem mutuamente - premissa que, segundo Gorelik (2002), concretiza-se na América Latina como 
em poucas partes do mundo -, há um ambiente particularmente fértil para as dialéticas uma vez que, na história americana, nota-se que frequentemente "as questões valorativas e conceptuais aparecem no mesmo momento, ou inclusive antecedendo os processos que as geraram em seus lugares de origem" (GORELIK, 1999, p. 59). Registros como a fotografia do carro de boi lembram-nos que, ao invés de abismos entre categorias que apenas permitiriam um arranjo antitético, em Goiânia - tal como num cenário mais amplo - haveria mesclas, coexistências e sobreposições. Assim, entre o que se enunciava e o que realmente se verificava na nova capital, se estabeleceria um eventual desalinhamento, como sugere LéviStrauss - que, apesar dum sentido distinto, também se valeria de um nexo referencial.

Do dia para a noite, os jornais se cobriram de anúncios de página inteira. Anunciavase a fundação da cidade de Goiânia; em torno de um plano pormenorizado, como se a cidade fosse centenária, enumeravam-se as vantagens prometidas aos habitantes: limpeza pública, estrada de ferro, água e esgotos, cinema. [...] Visitei Goiânia em 1937. Uma planície sem fim, que parecia, ao mesmo tempo, um terreno baldio, um campo de batalha, eriçada de postes de eletricidade e de estacas de agrimensura, exibia uma centena de casas novas dispersas pelos quatro cantos do horizonte. A mais importante era o hotel, paralelepípedo em cimento, que, no meio desse achatamento, evocava uma aero-estação ou um fortim; ter-se-lhe-ia aplicado de boa vontade a expressão "bastião da civilização", num sentido não mais figurado mas direto, que adquiria, com esse uso, um valor singularmente irônico. Pois nada poderia ser tão bárbaro, tão inumano, quanto esse empreendimento contra o deserto. Essa construção sem graça era o contrário de Goiás; nenhuma história, nenhuma duração, nenhum hábito havia saturado o seu vazio ou amenizado a sua rigidez [...] (LÉVI-STRAUSS, 1955/1957, p. 127-128)

Evidentemente, é necessário relativizar tais impressões. À semelhança dos juízos dos viajantes europeus do século XIX - embora Lévi-Strauss demonstrasse mais complacência com a Cidade de Goiás -, o francês, talvez assombrado pela visão de um planalto "coberto somente de capim duro e de espinheiras" e sem "nenhuma via férrea, nenhuma estrada de acesso, apenas alguns trilhos próprios para carroças" (LÉVI-STRAUSS, 1955/1957, p. 127), teceria uma visão própria sobre um empreendimento ainda em curso, pouco considerando o estágio alvorar e as especificidades locais. Em contrapartida, não se pode deixar de observar que, nos primeiros anos, a quebra de expectativas seria contumaz em muitos dos contatos iniciais com a nova capital. Afinal, recordemo-nos da frase de Paulo Augusto de Figueiredo (1943, p. 2) - "Goiânia não é coisa para ser vista; é coisa para ser compreendida" - que, de acordo com o crítico literário José Brito Broca (1944, p. 34), deveria estar inscrita logo na entrada da cidade "para prevenir o forasteiro contra juízos apressados" (os quais ele mesmo confessa ter tido num primeiro momento).

Muitos turistas, mais irrefletidos e irrazoáveis, chegam a reclamar ônibus, bondes e outros tantos elementos de uma grande cidade. Reclama-se também muito contra a terra vermelha, essas nuvens de pó, que erguidas a todo momento pelos veículos, deixam em estado lastimável a roupa de casemira e tornam impossível o uso do 
terno branco. De fato, com exceção de duas ou três avenidas, o resto da cidade ainda não tem calçamento. $O$ protesto contra a poeira já é um refrão indefectível em Goiânia. [...] Vi um companheiro de viagem, incapaz de refletir dois minutos, exclamar, cheio de má vontade: - "Mas isso é a tal cidade?...". Também eu reclamei, a princípio; não obstante, compreendi. [...] Seria possível, em seis anos, fazer uma pequena cidade mais compacta. As ambições de Goiânia, porém, são muito grandes para que ela logre atingi-las em pouco tempo. Lembremo-nos do que era Belo Horizonte com seus anos de vida. E Belo Horizonte, perto do Rio, num dos maiores estados do Brasil, em zona rica e povoadíssima. (BROCA, 1944, p. 33-34)

Destaca-se, por conseguinte, que concomitantemente às narrativas que sugeririam uma capital estritamente moderna, vislumbrava-se uma urbe repleta de carências próprias de um núcleo em formação (sobretudo ali, no sertão), num persistente estado de "vir a ser" que de modo multiforme permearia toda a construção da cidade - o que potencialmente provocaria frustrações diante do descompasso entre a expectativa gerada por parte dos discursos e a realidade matizada por um olhar cético. Em meio à diversidade de prismas e para além das alusões às vicissitudes, haveria então narrativas que adotariam uma perspectiva menos romantizada e, curiosamente, por vezes até mesmo propagadas por fontes enunciadoras comuns - visto que a existência das narrativas utópicas, amparadas sobretudo na simbologia da nova capital ou na expectativa de um porvir, no final das contas não pressuporiam a anulação de narrativas realistas que, mediante um referencial distinto, assumiriam um tom cético (SILVA, L. O., 2014). Assim, as simultaneidades equitativamente se transporiam para o campo discursivo.

Ademais, é importante encarar esses nexos não apenas como elementos exclusivamente particulares ou locais, conquanto tenham suas especificidades - como, por exemplo, o fato de maturarem-se numa cidade nova -, mas deve-se, sim, considerar a inserção de Goiânia numa lógica mais ampla. A cidade latino-americana, de acordo com Romero (1976/2005), se estabeleceria num jogo de desenvolvimento heterônomo - onde as mudanças seriam ditadas por modelos externos, como europeus - e de desenvolvimento autônomo onde as transformações derivariam das estruturas internas, a partir do qual, por exemplo, adviriam as facetas vernáculas. Este duplo processo, ainda segundo o autor, assim conformaria não somente as culturas urbanas, mas igualmente ditaria as relações entre o mundo rural e o mundo urbano - e "neste último é onde as ideologias adquirem mais vigor e afrontam mais claramente seu enfrentamento - um jogo dialético - com as estruturas reais" (ROMERO, 1976/2005, p. 20). Daí derivariam as acomodações, em meio a interlocuções e embates.

As antíteses, em suma, não seriam capazes de exprimir a complexidade do momento contemporâneo à construção da nova capital. Goiânia não se conformaria imbuída numa 
modernidade hermética, da mesma forma que não se presume Goiás (a cidade e o estado) imersos numa estagnação axiomática. No lugar das dicotomias, assume-se portanto a existência de dialéticas inscritas em Goiânia, manifestas nas distintas facetas de uma cidade cuja avenida central apresentava-se florida e exemplarmente simétrica, segundo Brito Broca (1944, p. 35) - mas que, após uma curta caminhada, logo conduziria o transeunte à selvagem "savana, nas campinas imensas do planalto central"; ou de uma cidade cujas residências alegadamente atentas aos modernos preceitos de arquitetura conviveriam com habitações improvisadas de adobe, madeira e palha, na região do Botafogo. É sob esta conjuntura dialógica que as representações de Goiânia se cristalizariam, sedimentando algumas das imagens da cidade.

\subsection{Retratos de Goiânia}

[...] normalmente, a vida na Goiânia de 1945 era pacata. A Avenida Goiás, deserta de prédios e de gente, a vida noturna concentrada diante do Grande Hotel, lugar oficial de namoro, as moças sempre em grupo, desfilando diante dos rapazes parados na calçada, admirando-as. Era o passeio noturno, a pé, o único divertimento, como em todas as cidades do interior do Brasil. (TURCHI apud GOIÂNIA, 1985, p. 180181)

Num poema premiado pela Academia Goiana de Letras contemporaneamente ao Batismo Cultural de Goiânia, Rosarita Fleury (1944, p. 32) se dirigiria a um visitante de terras distantes, de um "inferno a que chamam civilização" - onde não se conhecia o prazer de olhar o céu ou o deleite de andar lentamente pois desde cedo corria-se para não perder os bondes -, para desvelar a nova capital goiana. Pois Goiânia, em pleno Oeste brasileiro, seria sua cidade mais linda e faceira, repleta de irresistíveis encantos capazes de fazer com que o visitante não a deixasse mais - e passasse a sonhar o mesmo sonho que habitava o coração de todos os seus habitantes, a expectativa de Goiânia se tornar "um sol irradiando vida e calor aos pontos mais longínquos do sertão" (FLEURY, 1944, p. 33).

Como numa deambulação, Fleury (1944) descreveria os cenários da cidade. Mencionaria o bucolismo dos capinzais e buritis, que conviveriam com o vai-e-vem das ruas em formação, ladeadas por bangalôs rosados e modernos sobrados. Citaria a Avenida Anhanguera, movimentada como um formigueiro; a Avenida Goiás, com bancos cheios de casais num fim de tarde; e a Praça Cívica, com o silêncio de final de expediente apenas rompido pelo discreto canto das fontes luminosas. Bairro Popular, Vila Militar e até os chamados "bairros pobres" de Botafogo e Vilanova seriam igualmente lembrados, cada um com seus cotidianos particulares. E, na outra ponta da estrada, Campinas, estendendo seus braços para abraçar Goiânia - e se transformar em Goiânia também. 
Os versos de Rosarita, tal como outros artigos e contos, relatos e fotografias, contribuem para revelar imagens contumazes da cidade-concretude. Os diferentes elementos da capital apareceriam como referências coletivas que não apenas estremariam a experiência espacial da comunidade, mas, como símbolos eleitos, também atuariam na condição de matéria-prima do imaginário e da memória daqueles que vivenciavam o local. Em essência, não se pressupõem imagens absolutamente derivadas de literalidades ou exclusivamente fruto de um contato imediato entre os indivíduos e os elementos físicos da cidade uma vez que, segundo Lynch (1960/1999, p. 57), "há também outros fatores influenciadores da imagem, tais como o significado social de uma área, a sua função, a sua história ou, até, o seu nome”. Assim, diante de sua manifestação como representações - isto é, abarcando as "traduções mentais de uma realidade exterior percebida" (LE GOFF, 1985/1994, p. 11) ou almejada -, as imagens igualmente se estabeleceriam mediante um processo de abstração - e, a partir de seu papel mediador, simultaneamente retroalimentariam as visões acerca da nova capital.

Dentre as visualidades que comporiam os retratos da cidade, pode-se recuperar, por exemplo, o Cine-Teatro Goiânia, palco das solenidades da inauguração oficial - o que lhe conferiria uma "importância toda especial, pelo fato de que se constituiu como que uma apresentação da cidade ao País" (UNES, 2001 apud GOIÂNIA..., 2010, p. 131). Concebido por Jorge Félix de Souza com a colaboração de José Neddermeyer, o edifício seria um marco urbano tanto por situar-se no obliquo encontro de duas importantes avenidas (o que lhe garantiria certo destaque perspectivo) quanto por sua iconicidade, alinhada a uma orientação déco essencialmente urbana presente em rádios e cinemas da época. Suas feições streamlined sinalizariam modernidade a partir de uma estética industrial que, como lembra Correia (2008), se daria através do emprego de escalonamentos e elementos verticais que remeteriam a engrenagens, bem como esquadrias em forma de escotilha e volumes arredondado que sugeririam o convés de um navio. E esses traços permeariam a leitura de Rosarita de uma maneira curiosa: em que pese a alusão naval, Fleury (1944, p. 32) assimilaria as formas do edifício como uma evocação ao pretérito ao indicar que "o Cinema / revestido de cinza, com pintas prateadas / de linhas frias, de um belo esquisito / faz a gente pensar em cousas já passadas, / em gôndolas antigas, em pinturas do Egito!”.

A impressão de Rosarita Fleury, que a princípio poderia apresentar-se estranha a uma estética moderna prefigurada pelas linhas déco, não seria gratuita visto que, de fato, haveria motivos decorativos nas fachadas da edificação que pouco lembrariam maquinários. Isto se daria pois, de acordo com Bayer (1992/1999, p. 15), "assim como o estilo Art Déco nas artes aplicadas era um híbrido eclético [...], a arquitetura Art Déco era fundamentada pela variedade 
do antigo, exótico e mais recentes fontes". Desta forma, apesar de se dispor como reação a Beaux-Arts, o Art Déco poderia trazer aspectos sugestivamente egípcios (ou maias, assírios, bizantinos etc.) que seriam verificados muito distantes de suas culturas de origem e em obras assumidamente hodiernas.

Leitura semelhante ainda seria observada na legenda de uma fotografia do CineTeatro Goiânia na Revista Oeste, onde se associaria o aspecto externo da edificação a uma galera romana - embarcação antiga de proa avantajada -, conquanto diversos detalhes deixassem de aparecer pela qualidade da reprodução. De qualquer modo, a perspectiva diagonal realçaria a comparação, além de melhor permitir a apreensão da edificação - à medida que, diante de seu partido arquitetônico, a adoção de qualquer vista próxima da ortogonal implicaria dificultar a compreensão das formas.

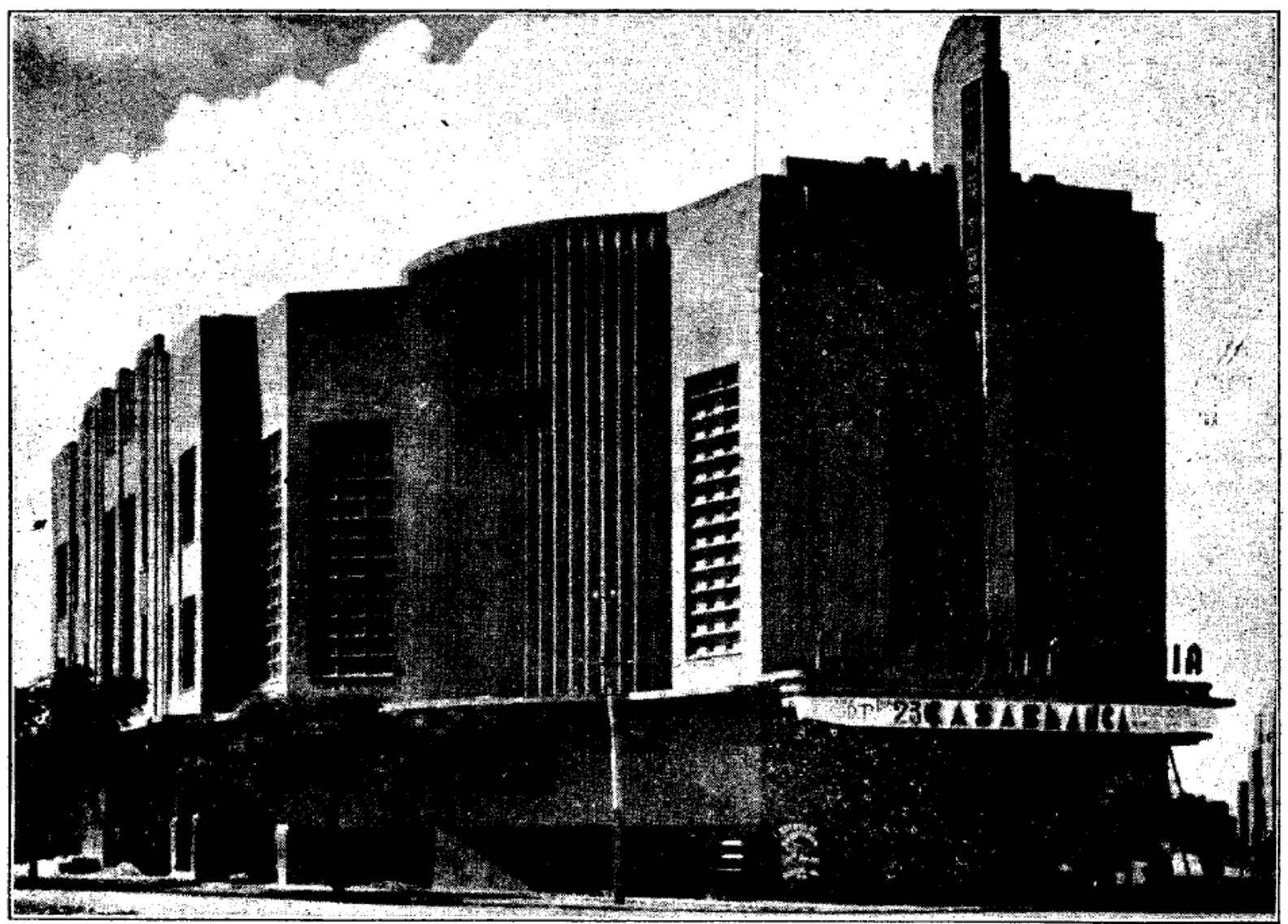

Figura 47: Cine-Teatro Goiânia. "Lembrando, no seu aspecto externo, uma galera romana, essa casa de diversões, situada na esquina das avenidas Anhanguera e Tocantins, foi montada com todo gosto e capricho pelo governo do Estado, que a dotou de uma moderníssima aparelhagem sonora e de exibição e de um mobiliário perfeito e confortável". Legenda da publicação. Autoria desconhecida. Fonte: Revista Oeste (1944).

Se o Cine-Teatro Goiânia seria um dos principais cartões de visita da cidade na ocasião do Batismo Cultural, o Grande Hotel, como um dos edifícios pioneiros, similarmente conformaria muitas das imagens iniciais da nova capital. Afinal, a hospedagem seria fundamental para abrigar muitos de seus primeiros e ilustres visitantes, ao mesmo tempo que 
se conformaria como um dos principais cenários de reuniões e da prática do footing - também chamado de vai-e-vem, uma popular atividade de lazer que basicamente consistia em passeios pela cidade -, assim convergindo parte da nascente vida social de Goiânia. Castro Costa (apud TELES, 1986/2012, p. 108), por exemplo, indicaria que em frente ao Grande Hotel se aglomerariam aqueles de "vida tranquila [...], de manhã à noite, fumando, tomando café pelas redondezas, contanto piadas, gargalhando estrepitosamente até os lóbulos das orelhas, comentando as pequenas notícias locais”, enquanto seu colega, Paulo Augusto de Figueiredo, relembraria do local como ponto de encontro da elite.

No Grande Hotel, reuniam-se, quase todas as noites, os figurões e intelectuais da terra, de permeio com os viajantes. Ali, a gente discutia política, literatura, esportes, problemas da administração, acontecimentos mundanos. Bebíamos, dançávamos, namorávamos. [...] Ali, estávamos sempre, uns mais assíduos, outros nem tanto, os casados mais comedidos, mas todos irmanados na empolgação por Goiânia, lutando por sua consolidação e grandeza. (FIGUEIREDO, P. A., apud TELES, 1986/2012, p. 205-206)

Um registro no álbum Lembranças de Goiânia: "a capital caçula”, atribuído ao fotógrafo italiano Sílvio Berto, pareceria confirmar esses ares de urbanidade em torno do Grande Hotel. A fotografia, datada na década de 1940, traria aspectos físicos que sinalizariam a consolidação do núcleo, como o adensamento edílico na Avenida Goiás, a presença de infraestrutura urbana e o maior porte da vegetação - ressaltado pelo fotógrafo ao incluir em sua composição os ramos da árvore que o abrigava no canteiro central; porém, sem citar a oportuna presença de veículos (em contraponto aos transportes de tração animal), destaca-se a apropriação do espaço por figuras humanas (algo não tão presente nas primeiras fotografias de Goiânia), evocando uma dinâmica ainda não metropolitana, mas que ganhava contornos citadinos congruentes a parte dos relatos. Deste modo, o quadro, permeado por grupos que se aglomerariam sob marquises e frondosas copas de árvores, em pé ou sentados ao longo da larga calçada da via central da cidade, demonstraria o edifício e seu entorno como relevantes espaços de sociabilização, e onde gradativamente delineavam-se as imagens boulevarescas almejadas por Attilio Corrêa Lima - conquanto, lembremo-nos, houvesse modificações no zoneamento por ele idealizado.

A avenida Pedro Ludovico tem um caráter pitoresco e monumental, constituindo uma avenida-jardim. [...] Pela sua largura excepcional e pelo seu aspecto luxuoso, prestar-se-á para as demonstrações e festas cívicas. [...] Na avenida Pedro Ludovico só deverá ser tolerado o comércio de luxo, casas de modas, joalherias, cafés, bars e restaurantes com instalações de gosto. (LIMA, A. C., 1937/1942, p. 101-103) 


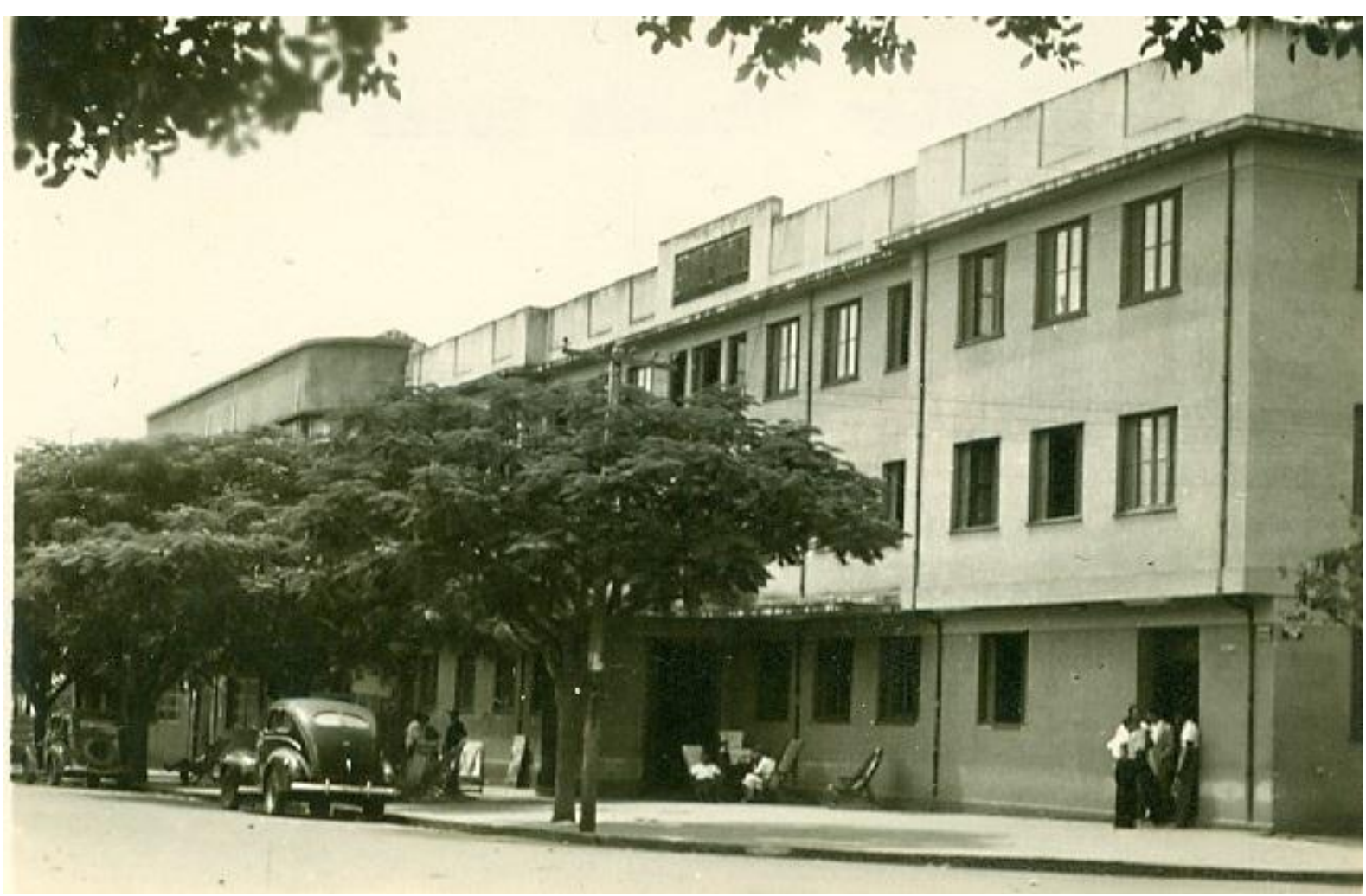

Figura 48: Grande Hotel. Foto do álbum: Lembranças de Goiânia, "a capital caçula". Goiânia-GO. Década de 1940. Sílvio Berto. Fonte: Acervo MIS/GO.

Ainda é interessante notar que, em que pese o caráter quase austero de suas linhas ${ }^{31}$, o edifício inicialmente idealizado por Corrêa Lima despertaria admiração. Pioneiros como o potiguar Pedro Meireles (apud GOIÂNIA, 1985) recordariam da grandiosidade daquela obra que, com os seus três pavimentos, remeteria a um verdadeiro palácio. Já Pierre Monbeig (1938/1942, p. 77), ao descrever sua visita à capital de Goiás, afirmaria que a cidade já possuía mais de duzentos edifícios "mais tentadores que os de numerosas cidadezinhas antigas do interior paulista" - e, dentre eles, o Grande Hotel, "cujo asseio e mesa fazem com que o viajante se esqueça que está no coração do sertão". A impressão do francês seria de um êxito indiscutível (MONBEIG, 1938/1942).

\footnotetext{
${ }^{31}$ Conforme já indicado, os edifícios empreendidos pelo poder público, a exemplo do Grande Hotel, seriam marcados por uma arquitetura que, em essência, visava distanciar-se das imagens evocadas pelas construções da Cidade de Goiás. Nesse sentido, apesar das alterações em obra, as concepções de Corrêa Lima - assim como da Firma Coimbra Bueno ou de outros profissionais, incluindo aqueles contratados por particulares, que absorveriam referências alinhadas aos edifícios pioneiros - via de regra se disporiam congruentes aos anseios de modernidade ao lançar mão de formas que, na medida do possível, sinalizariam uma arquitetura de caráter racional. No entanto, também é preciso considerar que tal orientação arquitetônica se demonstraria conveniente aos poucos recursos orçamentários que dispunha o governo estadual. Armando de Godoy (1933/1943, p. 215), por exemplo, ao argumentar sobre a viabilidade financeira de se transferir a capital, afirmaria a Pedro Ludovico que "um edifício público não precisa ser constituído por materiais caros para se impor à admiração geral sob o ponto de vista estético. A beleza de uma construção está na relação das suas diferentes partes e na distribuição de seus volumes". Ademais, haveria ainda um aspecto construtivo à medida que, como expõe Monegatto (2013, p. 90), "alguns princípios modernos se encaixaram perfeitamente nas justificativas das novas formas de produção" pautadas no trabalho parcial (e com a gradual supressão da figura do artífice), tal como a economia na construção, a padronização e a simplificação das formas arquitetônicas.
} 
O sucesso na concretização do Grande Hotel, destarte, aparentaria simbolizar o sucesso da própria concretização de Goiânia. Num artigo publicado no Correio Oficial, a cobertura da inauguração do edifício no alvorecer de 1937 seria marcada por uma exultante tônica de realização. O desígnio tomava corpo e, como se metaforizando o empreendimento da nova cidade, se afirmaria que aquela "obra arquitetônica que é bem a síntese da grandeza de um povo progressista" em nada deixaria a desejar, "rivalizando em tudo com os melhores dos centros mais adiantados" (INAUGURAÇÃO..., 1937, p. 1).

Meus senhores: inaugura-se hoje, e sob as vossas vistas, o "Grande Hotel", de Goiânia. Ontem, era um sonho, uma quimera e quiçá uma loucura; hoje, uma simples realidade. Simples, bem simples, um Hotel! Mas um Hotel construído com rigorosa observância das exigências atuais e da arte moderna. [...] Deve ser particularmente caro, ao goiano, o contato e a intimidade com esta obra, erguida neste rincão querido, ornamento majestoso da principal artéria da sua futura capital, no centro de Goiaz - coração do Brasil! (INAUGURAÇÃO..., 1937, p. 1)

Sem embargo, assim como Goiânia, o Grande Hotel constantemente pareceria situarse entre dois mundos. O cosmopolitismo, encarnado pelos homens letrados e viajantes, dialogaria com o particularismo dos prosaicos tipos de rua, que seriam contumazes frequentadores das imediações. Ou, caso o visitante esquecesse estar no Brasil mediterrâneo, dado o requinte das instalações da hospedagem, bastaria debruçar-se sobre a sacada conforme recomendaria um anúncio publicitário recuperado por Ofélia Monteiro.

De suas sacadas o turista poderá contemplar, em toda sua plenitude, essa luta ciclópica entre um povo que vai construindo sua cidade e a Natureza virgem, travada em uma das mais encantadoras paragens do "Hinterland" brasileiro. Duelo imponente em que a mão do homem apenas aumenta a beleza verdadeiramente edênica da paisagem. Misto de cidade e de sertão. Visitai Goiânia, a caçula das capitais brasileiras e hospedai-vos no GRANDE HOTEL. (GRANDE... apud MONTEIRO, O. S. N., 1938, p. 439)

Nesse sentido, relatos como o de José Júlio Lima (apud TELES, 1986/2012) dariam indícios de como se estabeleceria efetivamente a relação edifício-cidade, especialmente em seus primeiros anos. O mineiro, ao narrar sua chegada a Goiânia, classificaria o hotel que lhe abrigara como um oásis em meio ao matagal - num momento em que as acomodações se dispunham, sobretudo, em Campinas.

Ali me hospedei, por ser o único, temeroso de que os $400 \$ 00$ mensais não dessem para tamanho luxo. Apresentado ao arrendatário (Neném Veiga), perguntei-lhe:

- Qual o custo para um hóspede mensal?

- Apartamento de frente ou de fundo?

- Há diferença de preço?

- De frente, 180\$00; de fundo, $150 \$ 00$.

Querendo bancar o importante, disse-lhe: "Prefiro o de fundo, por ser mais tranquilo" (tranquilidade em uma cidade em construção, sem frente e sem fundo, em pleno cerrado, onde só se ouvia o ladrar dos cães). (LIMA, J. J. G. apud TELES, $1986 / 2012$, p. 129) 
Diante deste cenário inicial, seriam usuais as tomadas fragmentadas - recurso bastante popularizado nas fotografias especialmente nas décadas de 1920 e 1930 (LIMA, S. F.; CARVALHO, 1997/2008) -, de modo a valorizar o conjunto construído em detrimento do contexto urbano (quando este último ainda não se prefiguraria condizente aos brados de progresso que a plasticidade arquitetônica poderia emanar). A fotografia do Grande Hotel tomada por Sílvio Berto, embora também detenha um caráter parcial, não necessariamente assumiria este uso uma vez que, naquele momento, a cidade já se encontrava num expressivo processo de adensamento - o que seria verificável através de outras fotografias panorâmicas no mesmo álbum. Já uma fotografia de Alois Feichtenberger, tomada no ano de inauguração do hotel e reproduzida em jornais como $O$ Popular e $O$ Estado de S. Paulo, melhor exemplificaria o emprego deste tipo de perspectiva - apesar da utilização de uma fotografia de enquadramento fechado igualmente justificar-se pelo cunho comercial de determinadas veiculações.

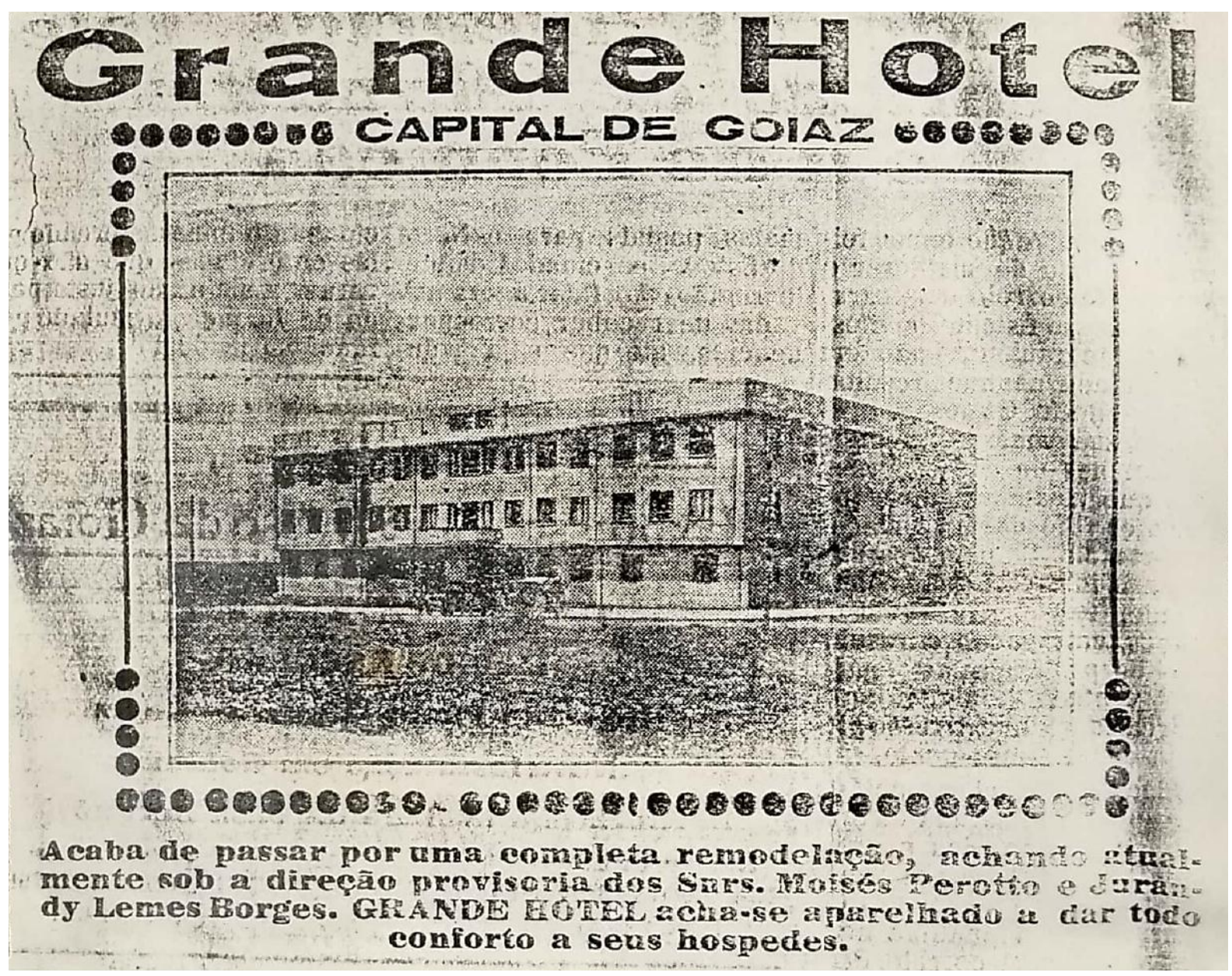

Figura 49: Grande Hotel em recorte do jornal O Popular. Alois Feichtenberger. Fonte: O Popular (1939)/Acervo da SEPLANH.

Impressões como de Lévi-Strauss (1955/1957, p. 128) - que identificaria o hotel como elemento de destaque mas, recordemo-nos, classificaria o edifício como um 
"paralelepípedo de cimento" em meio ao achatamento -, por conseguinte, não seriam tão difíceis de compreender se observadas à luz de registros como do português Antônio Pereira da Silva, cuja captura aérea figuraria em exemplares como o Álbum de Fotografias sobre o Planejamento e Construção da Cidade de Goiânia e o Álbum de Goiaz - e, nesses casos, curiosamente em diálogo com a fotografia de Feichtenberger. Visualmente, o bloco edificado se sobressairia no núcleo de ocupação ainda rarefeita, num estado que permaneceria manifesto alguns anos após sua inauguração.

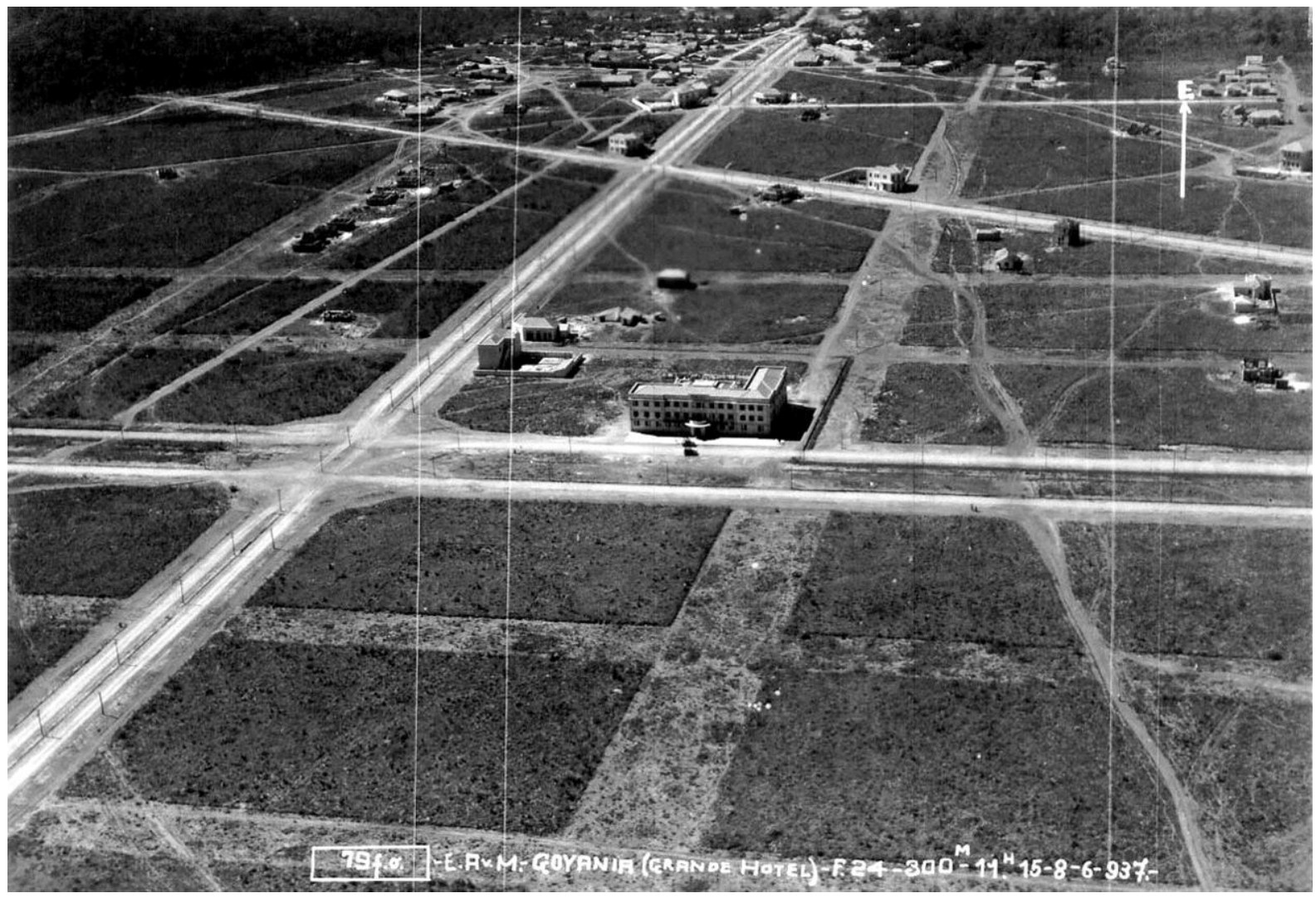

Figura 50: Grande Hotel em 1937. Escola de Aviação Militar/Antônio Pereira da Silva. Fonte: Acervo do CPDOC-FGV.

Outrossim, tal como Goiânia em seus primeiros anos, o Grande Hotel, a despeito das novíssimas instalações, padeceria da falta de água e luz verificada em toda cidade. José Júlio Lima (apud TELES, 1986/2012) continuaria seu relato, lembrando-se justamente deste aspecto.

Como estivesse empoeirado da viagem, quis tomar banho, mas ao abrir o chuveiro, cadê a água?

Procurei o gerente, um português, Sr. Pinto, recém-chegado de São Paulo, onde trabalhava em hotéis 5 estrelas, muito bem-educado, [...] vestido ao rigor da moda, a quem reclamei.

Respondeu-me, a título de consolo:

- Não se procupe, pois houve o rumpimento de um dos canos de abastecimento, mas dentro de 24 horas estará tudo sanado, segundo prumessa do administrador das obras.

- Mas onde poderei banhar-me? 
- O jaito é o rio Meia Ponte.

- É perto daqui?

- Pois fica a uns dez quilômetros.

Foi realmente o jeito, e desse rio me tornei frequentador assíduo, procurando-o todas as manhãs, [...] à guisa de esporte. (LIMA, J. J. G. apud TELES, 1986/2012, p. 129)

Teria sido o Grande Hotel, inclusive, palco do folclórico episódio ocorrido durante a visita de Monteiro Lobato à capital goiana - uma passagem breve, na verdade, encurtada à medida que o visitante se irritara com as limitações da infraestrutura. Daí derivariam os famosos versos do escritor, deixados na portaria na ocasião de sua saída - conforme asseguraria Élis (apud GOIÂNIA, 1985, p. 58): “Goiânia, cidade linda, / que nos encanta e seduz / de dia não tem água / de noite não tem luz”. Um juízo irrazoável, de acordo com Brito Broca (1944).

\begin{abstract}
Parece-me que a maioria dos turistas que chega à nova capital experimenta, a princípio, uma desilusão. Isso porque não se lembra, nos primeiros momentos, das circunstâncias em que se acha condicionado aquele fenômeno urbano; não se lembra de que a cidade tem seis anos apenas e se encontra no Brasil Central, numa região deserta, fora do alcance da estrada de ferro, a uma distância imensa do Rio [...]. Monteiro Lobato ficou furioso e desancou o grande empreendimento de Pedro Ludovico, somente porque lhe aconteceu, no hotel de Goiânia, o que poderia ter acontecido em qualquer hotel das melhores cidades do mundo. (BROCA, 1944, p. 33-34)
\end{abstract}

Monteiro Lobato, contudo, demonstraria ter ciência prévia das limitações de uma cidade nova no coração do Brasil, como se percebe em Geografia da Dona Benta - obra originalmente publicada em 1935, anteriormente à sua visita. De acordo com sua personagem, a dificuldade de transporte seria motivo para que a região não se desenvolvesse tão rapidamente quanto às áreas litorâneas e, enquanto a questão não fosse sanada, o estado conservaria seu caráter pastoril. Todavia, a hora de Goiás iria chegar: num futuro breve, sua nova capital atrairia inúmeros visitantes. (LOBATO, 1935/1995).

Por enquanto Goiânia está criancinha ainda. Está se formando - mas está se formando certa, e ficará tão linda como Belo Horizonte. Já vi a planta da cidade. Ótima. Tudo está previsto. Dentro duns vinte anos o resto do Brasil se espantará com o encanto da nova capital. (LOBATO, 1935/1995, p. 34)

De qualquer modo, em meio àquela cidade em seu engatinhar, problemas de infraestrutura de fato seriam corriqueiros, de sorte que frequentemente assumiriam a ordem do dia na imprensa local. Numerosas reportagens de jornal, sobretudo na Folha de Goiaz - jornal mais vendido do estado entre o final da década de 1940 e início da década de 1950 (MEDEIROS, E., 2015) -, noticiariam o drama no nascer da capital, que se agravaria com o rompimento da barragem do Jaó no ano de 1945. Numa matéria datada nos fins da década de 1940, via-se com desconfiança a promessa (mais uma) de melhoria no abastecimento de 
energia elétrica. O tom da notícia era categórico: a cidade sem força suficiente seria uma cidade de progresso entravado, uma cidade sem conforto (MAIS..., 1949).

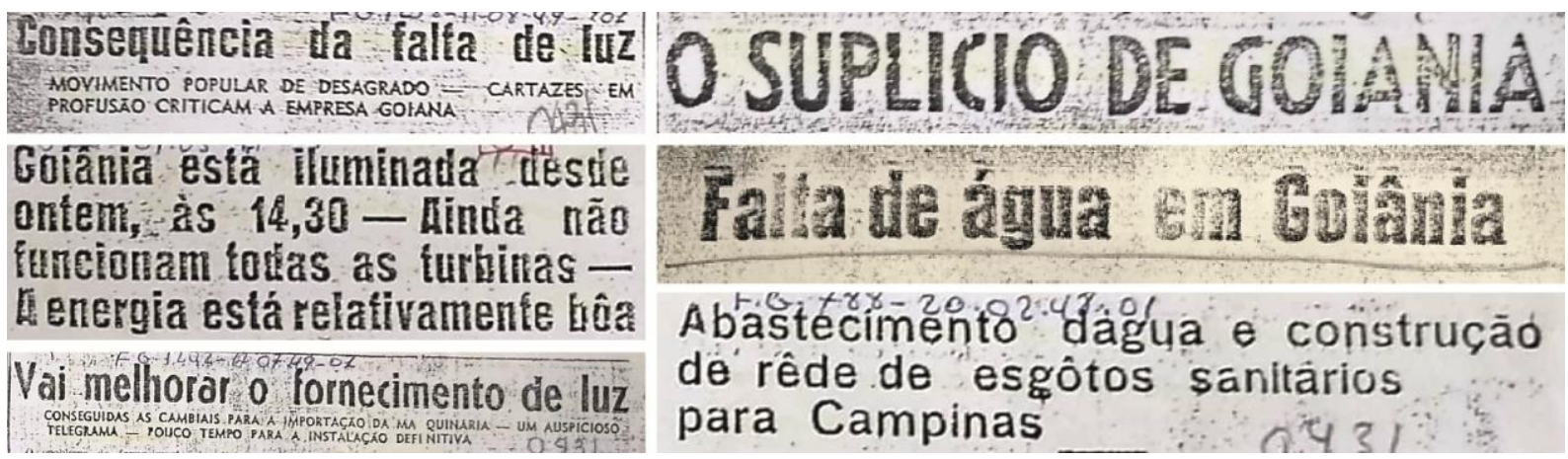

Figura 51: O problema de desabastecimento em recortes de jornais. Fonte (sentido horário, a partir do canto superior esquerdo): Folha de Goiaz (1949); Folha de Goiaz (1949); Folha de Goiaz (1947); Folha de Goiaz

(1948); Folha de Goiaz (1949); Folha de Goiaz (1947)/Acervo da SEPLANH, modificado pelo autor.

Nesta perspectiva, se observariam depoimentos como de Rosarita Fleury, a autora do poema no início desta seção. Rosarita recordaria que "à noite, com a falta de luz elétrica, a escuridão era total. Sem força a água não subia nos encanamentos, assim, naqueles primeiros tempos, a água era carregada em latas para o consumo caseiro” (FLEURY apud GOIÂNIA, 1985, p. 163). Diante do quadro, surgiria a impressão que Goiânia inicialmente não passaria de uma grande fazenda, dada "a extensão dos campos em torno e a escuridão à noite" (FLEURY apud GOIÂNIA, 1985, p. 162). E, na ausência de uma solução definitiva, gradativamente se criariam alternativas para, na medida do possível, não prejudicar as atividades da nova capital - como revelaria a musicista Belkiss Spenciére de Mendonça.

[...] a gente não tinha ferro elétrico, não tinha geladeira, não tinha enceradeira, não tinha nada, a cidade toda estava no escuro, no aladim. Mas o cinema tinha um motor, então, como a cidade era pequena e havia poucas construções a hora em que o motor do cinema era ligado, todo mundo ouvia e já saía de casa para ir assistir o filme. Cada um com sua lanterna na mão para não cair nos buracos das ruas, mas ia ao cinema. Assim era feito também nos dias de concerto. Tudo a gente poderia fazer no cinema porque lá havia esse motor. [...] Quer dizer, foi uma época em que Goiânia sofreu, foi uma época de que a gente não esquece porque tinha muita coisa boa dentro daquele sofrimento, da precariedade da cidade. (MENDONÇA, B. S. C. apud GOIÂNIA, 1985, p. 224)

A situação de carência se impregnaria tanto ao imaginário da população que chegaria a ser tema de moda caipira, como a intitulada "O cartaz da Luz em Goiânia". A canção, interpretada por Zé Micuim ${ }^{32}$ (também autor da letra) e Chico Onça numa rádio local - e transcrita numa reportagem de jornal -, traria um humor carregado de ironia, demonstrando

\footnotetext{
32 A Zé Micuim, juntamente com Goiazinho e Goiá, também se atribuiria a primeira canção composta sobre Brasília (CONSTRUÇÃO..., 2013). De 1955 (e, portanto, anterior à gestão de Juscelino Kubitschek), a guarânia homônima à capital federal chegaria a citar o engenheiro Jerônimo Coimbra Bueno como agente fundamental para concretização do que, naquele momento, seria o grande sonho dos goianos: a transferência do Palácio do Catete para Goiás.
} 
outros meios de expressar o descontentamento com o "já escandaloso caso da luz de Goiânia" (O HUMORISMO..., 1943, p. 4).

Nois agora vai falar / Fais favor preste atenção / É da luis qui tem aqui / Pra tocar nossa Estação / Começa cantar no craro / Acaba na escuridão / Inda dis qui a luis é bôa / Tá ligado alta tenção / Si a luis de Goiânia é bôa / Ninguem pode obiservar / Ajente anda na rua / Nada pode inchergá / Um pergunta pra o outro / Isto é luis ô é luar / O amigo então responde / Eu num sô daqui num posso afirmar / Outro dia um vagalumi / Tava com a luis acêsa / Formô um confusão / Chamaro lá na impresa / Chegô os eletricistas / Tivero grande sulprêsa / Esta luis ainda é firme / I a daqui não tem firmêsa / [...] Eu quiria ser um torpedo / Pra cair lá na usina / A luis subia de posto / Passando a lamparina / Melorava pra Goiânia / E também lá pra Campina / Esta luis tá imporcaiano / A nossa Capital minina. (MICUIM apud O HUMORISMO..., 1943, p. 4)

Os supostos matutos de linguagem coloquial, que não criticavam a cidade e sim a péssima qualidade do serviço de iluminação, pareceriam ser capazes de subverter a lógica que se esperaria da modernidade. Afinal de contas, para eles, a vetusta lamparina em princípio seria melhor que o sistema de iluminação pública previsto para a nova capital, cuja persistente deficiência aparentaria escapar de qualquer providência dos técnicos. A sátira assim lembraria, de certa forma, o que Morse (1984/1995) descreveria como contraponto entre a ingenuidade e o cosmopolitismo - no caso, referindo-se à literatura latino-americana -, algo iminentemente amplificado pela implantação de Goiânia no próprio hinterland.

A literatura logo registrou o significado complexo da cidade latino-americana, que desempenhava um papel de mediação incerta entre seu hinterland e as Londres e Paris de além-mar. Essa situação ambivalente e acidental tornou-a vulnerável a certos tipos de sátira - a visão ingênua, ou maliciosa, da cidade pretensiosa através dos olhos do caipira observador - que não parecem abundar na tradição literária das cidades europeias, mais reverenciosas. (MORSE, 1984/1995, p. 214)

Não obstante, a circulação de críticas animosas ou jocosas não impediria a concomitante existência de discursos, textuais ou não, que sugestivamente sinalizariam a plenitude dos serviços de infraestrutura na nova capital. Numa reportagem de 1939, por exemplo, se afirmaria com certa expectativa que, apesar da luz elétrica pouco eficiente desde a sua fundação, Goiânia enfim estaria verdadeiramente iluminada (GOIANIA..., 1939).

Com as novas instalações de que atualmente dispõe a Empresa, está sendo toda a cidade, desde aquela noite, magnificamente iluminada. Suas avenidas e ruas constituem um conjunto harmonioso e simétrico singularmente embelezado pela regularidade absoluta de lâmpadas potentes. Registramos com prazer o fato. (GOIÂNIA..., 1939)

Já o registro fotográfico da obra de instalações elétricas de uma casas-modelo poderia pressupor acesso integral aos confortos das construções hodiernas, mesmo que fosse apenas em determinados trechos da cidade - o que, como tudo indica, não aconteceria inicialmente. 


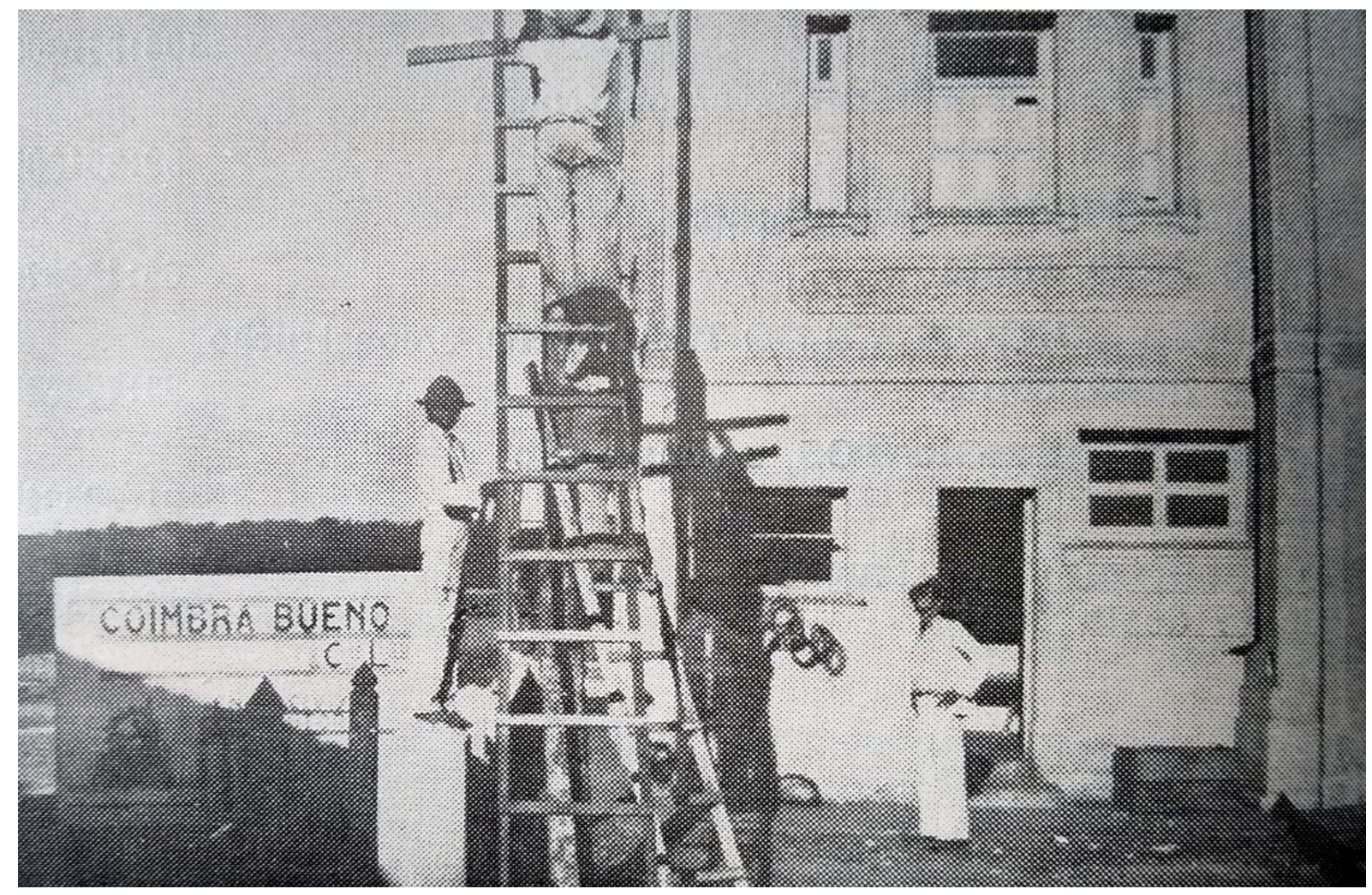

Figura 52: "Instalação de luz elétrica, nos prédios tipo 'casas-modelo', - da Rua 20 (detalhe)". Legenda da publicação. Autoria desconhecida. Fonte: Alvares (1942).

Independentemente dos percalços decorrentes da ainda irregular provisão, não deixa de ser curioso notar como a previsão de determinadas instalações em residências contribuiria para dotá-las de um caráter inovador. Célia Britto (apud TELES, 1986/2012, p. 43) rememoraria que as casas sob os moldes desta da fotografia detinham um "conforto ainda [...] desconhecido por muitos", enquanto Castro Costa (apud GOIÂNIA, 1985, p. 96) revelaria que as elegantes habitações que surgiam na cidade - cujas feições faziam lembrar as urbes litorâneas - "apresentavam uma novidade em Goiás - que eram os banheiros com instalação de vasos sanitários". Embora seja necessário relativizá-las, tais impressões seriam consonantes ao afã de estabelecer uma distinta lógica construtiva na nova cidade.

Seria inteiramente absurdo tomar-se como termo de comparação para se estabelecer o nível higiênico e arquitetônico das construções daqui, os prédios construídos até então no Estado. Não se podia justificar que se fizesse cidade nova (em virtude de não se ter outra que apresentasse condições de salubridade aceitáveis para a capital) e se tomasse como base as construções feitas nessas cidades. Nunca fazer cousa nova para corrigir os erros e tomar os erros como padrão de corrigenda. Não nos esmorecem as críticas neste terreno, estamos por demais seguros do que fazemos. Felizmente que é bem este o pagamento de nossos administradores e podemos assim construir aqui casas que marcam um avanço de cem anos na rotina asfixiante das nossas antigas habitações. (COIMBRA BUENO \& CIA LTDA., 1936 apud MONTEIRO, O. S. N., 1938, p. 469-470)

Ademais, como alternativa à asfixia das velhas residências, ainda se lançaria mão de diversos recursos edílicos e urbanísticos consonantes às exigências de salubridade tão 
evocadas ao longo da transferência da capital. Uma série de parâmetros seriam expressamente indicados no primeiro Código de Obras de Goiânia (1937 apud ALVARES, 1942), tal como distâncias mínimas em relação à frente e às laterais de lotes (de cinco metros, no primeiro caso, e de um metro e meio a dois metros e meio, no segundo), taxa de ocupação (de, no máximo, 35\% para zonas residenciais) e áreas mínimas dos ambientes (com flexibilizações para as habitações operárias do Bairro Popular). Ao mesmo tempo, as divisas dos lotes residenciais não poderiam ter muros superiores a um metro de altura. Essas diretrizes gerariam uma paisagem urbana particularmente nova na região - e especialmente valorizada em fotografias parciais e perspectivadas, destacando contrapontos às vias das antigas cidades, de edifícios adossados entre si -, o que reverberaria no imaginário de pioneiros como o pirenopolino Uassy da Silva.

Quando cheguei a Goiânia, uma coisa me chamou muito a atenção. As ruas me pareciam bastante largas e as casas bem distantes uma das outras. Eu era criança e vinha de uma cidade de arquitetura colonial onde as casas eram construídas juntas umas das outras. Interessante lembrar que naquela época, as casas eram sempre precedidas de jardim que separava a casa, do passeio, em cinco metros, e era observada a distância que variava entre um, dois ou cinco metros, uma das outras características totalmente diferentes da cidade da qual eu vinha. Primeiro porque as nossas casas não tinham jardim, pois elas foram construídas rés do passeio e depois juntas umas das outras. Tínhamos sim, formidáveis quintais em Pirenópolis. Esse recuo de 5 metros para os jardins das casas, nos dava a impressão de que a rua era muito mais larga do que na realidade. Então isso me impressionou bastante em Goiânia. (SILVA, U. G. apud GOIÂNIA, 1985, p. 333)

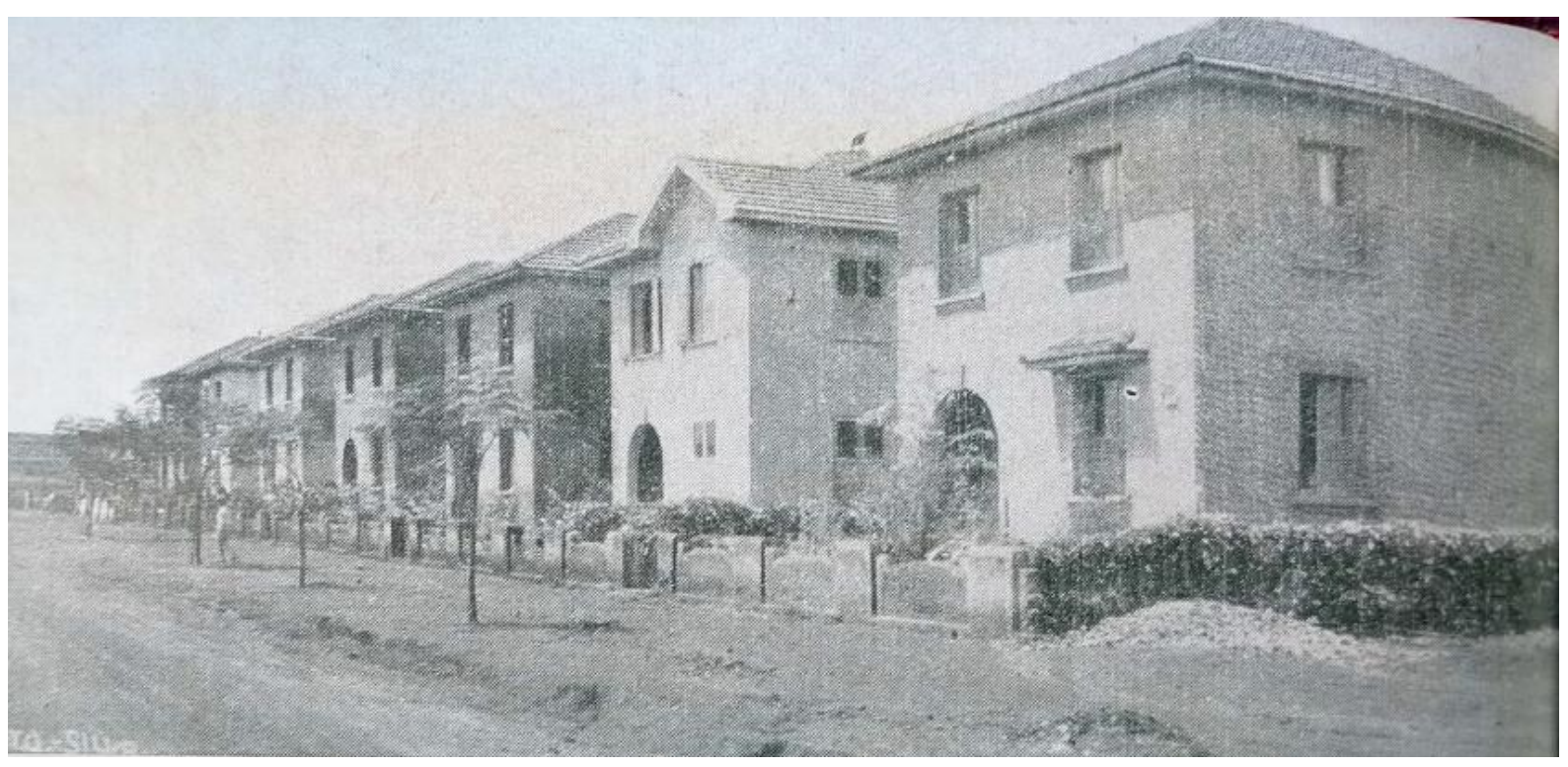

Figura 53: "A nova capital de Goiaz vai sendo, pouco a pouco, enriquecida de belas e confortáveis habitações particulares". Legenda da publicação. Antônio Pereira da Silva. Fonte: IBGE (1942).

Aos olhos da população, portanto, os novos padrões arquitetônicos das primeiras residências pareceriam suficientes para classificá-las como modernas - embora por vezes houvesse muito pouco do que convencionalmente se associaria à arquitetura moderna, em 
mais uma das polissemias do termo ${ }^{33}$. Por outro lado, existiriam habitações pioneiras que efetivamente incorporariam traços de uma arquitetura de novas orientações - como a residência do interventor Pedro Ludovico Teixeira, concebida pelas firmas Coimbra Bueno e Pena Chaves Ltda. - e, por sua vez, juntamente com os edifícios públicos, provocariam reverberações curiosas em Goiânia e Campinas: conforme afirmaria Wolney Unes (2001 apud ARRAIS, 2012, p. 187), suas feições se tornariam referências para agentes da construção civil (como mestres de obras e pedreiros) que, "após observarem os novos e monumentais edifícios da nova capital, tentavam reproduzir em suas obras aqueles frisos, ornatos ou o coroamento".

Esses artesãos agiam por imitação, fosse por iniciativa própria - o que é mais provável - fosse a pedido do proprietário-consumidor. Ao adornar um barracão de taipa ou mesmo de adobe com um imponente zigurate na platibanda, ao dar a forma quadrada ao capitel de um pilar, o mestre-de-obra fechava a ponta de um círculo estilístico que realizava a troca de influências numa escala planetária pela primeira vez na história. (UNES, 2001 apud ARRAIS, 2012, p. 187)

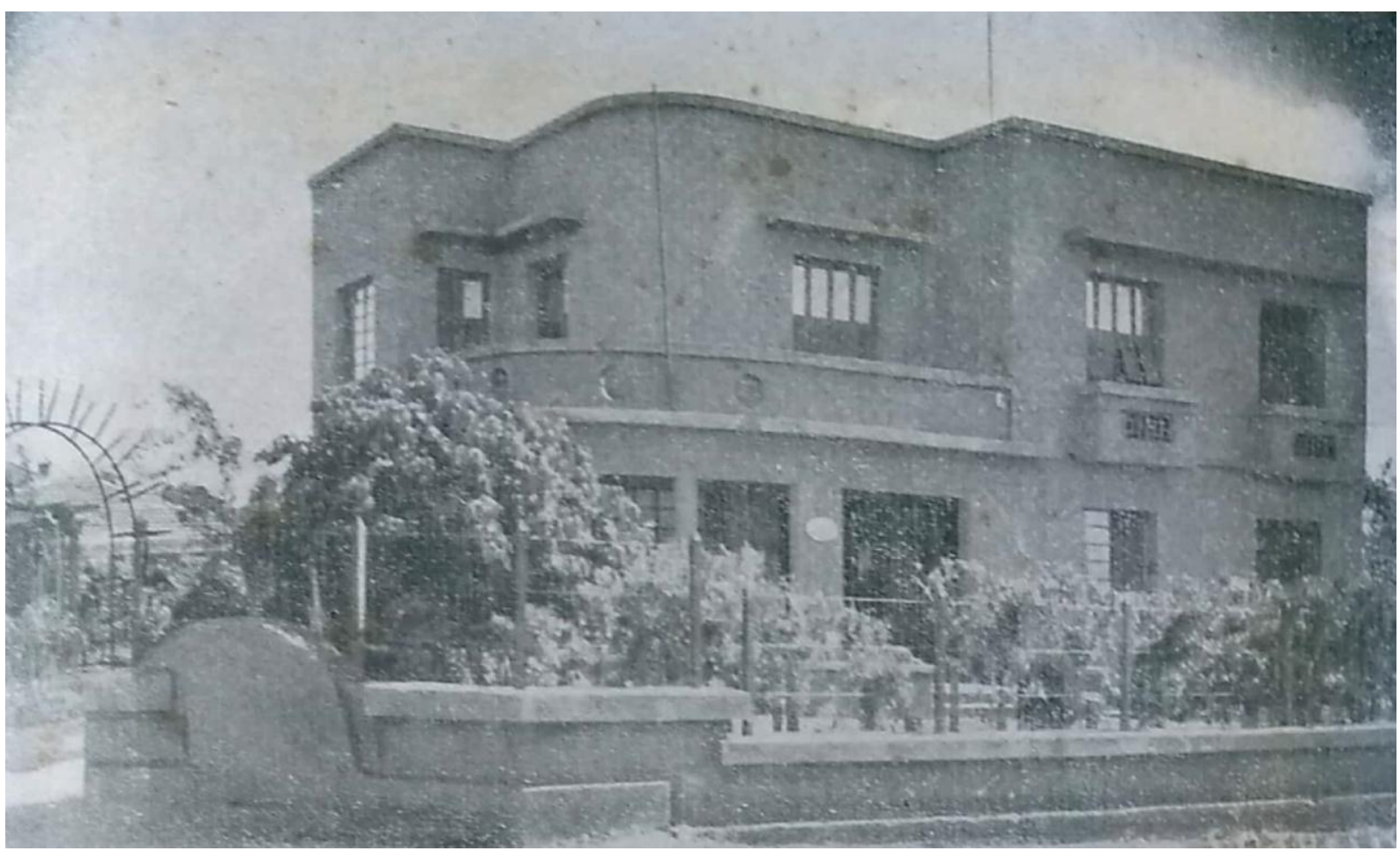

Figura 54: Residência de Pedro Ludovico Teixeira. "Goiânia - tipo de casa residencial". Legenda da publicação. Antônio Pereira da Silva. Fonte: IBGE (1942).

\footnotetext{
${ }^{33}$ No final da década de 1920, frente a um momento de transição onde era comum a confusão de termos, Gregori Warchavchik (1929/2006) passaria a empregar a expressão arquitetura nova ao invés de arquitetura moderna. O motivo, segundo o arquiteto, se daria "justamente para bem marcar a diferença entre as duas e para indicar que não se trata aqui daquela arquitetura que todo mundo chama de moderna, embora de moderno tenha muitas vezes somente o banheiro e a instalação elétrica" (WARCHAVCHIK, 1929/2006, p. 161). Assim, para Warchavchik (1929/2006, p. 161-162), a arquitetura nova seria "aquela que sabe aproveitar o ensinamento dos grandes mestres e a experiência adquirida durante os séculos e que, apesar disto e justamente por isto, segue a linha de desenvolvimento da humanidade e corresponde às necessidades técnicas e estéticas do homem do século XX, bem diferente na sua mentalidade do homem de outros tempos".
} 
Alguns destes edifícios de cunho mais nobre seriam profusamente veiculados em publicações e álbuns e, em concomitância, se publicariam registros de residências proletárias para reforçar a imagem de uma cidade para todos. "Também os operários não foram esquecidos em a nova capital que surge no centro do coração do Brasil”, indicaria a legenda de uma fotografia de casas operárias no compêndio do Instituto Brasileiro de Geografia e Estatística (1942) - por sinal, na mesma página da figura 53 -, de modo que, mesmo com diferentes tipologias construtivas, se pressuporia a garantia de satisfatórios requisitos de habitabilidade.

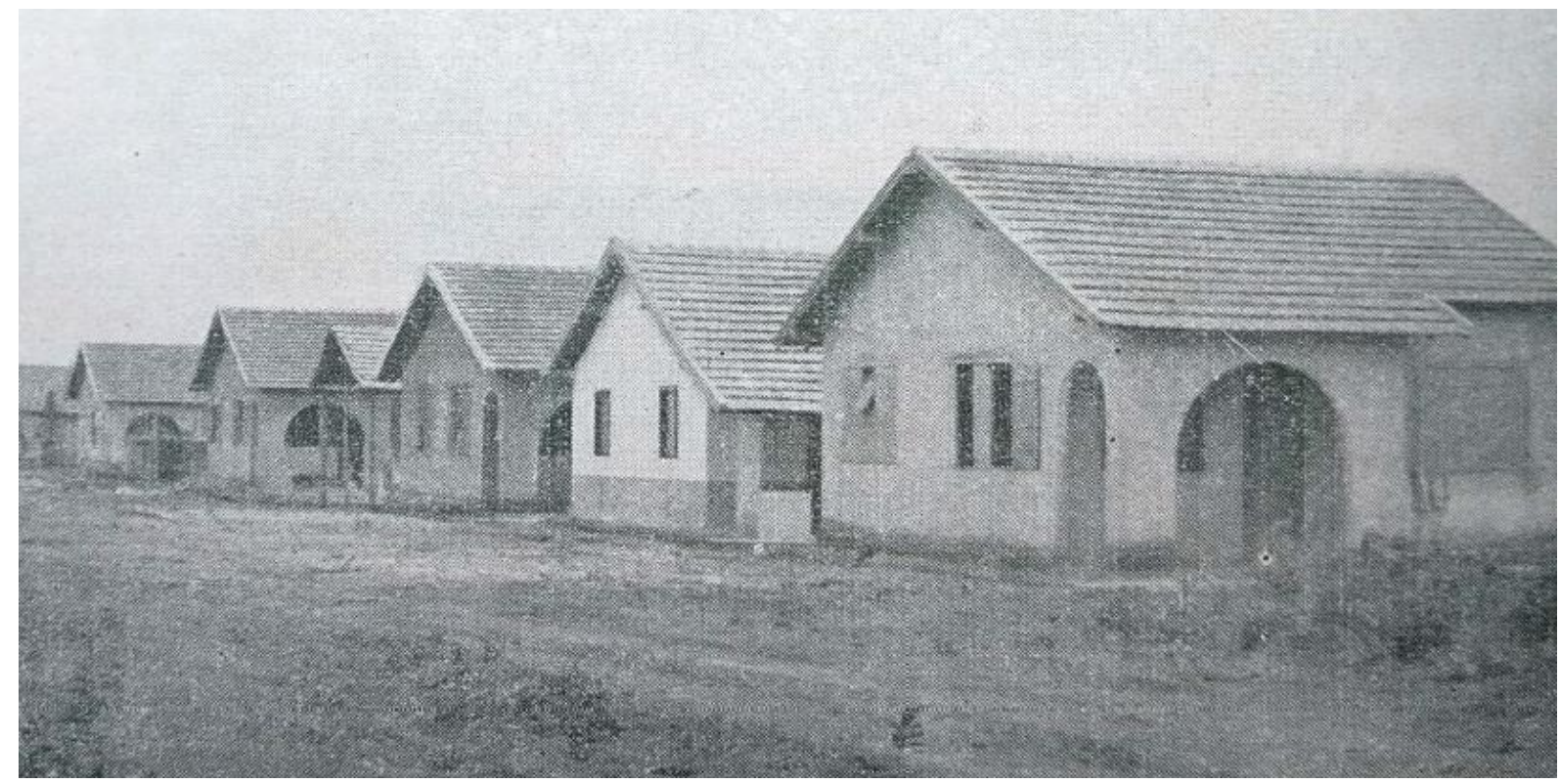

Figura 55: "Também os operários não foram esquecidos em a nova capital que surge no centro do coração do Brasil: algumas habitações do bairro proletário". Legenda da publicação. Autoria desconhecida. Fonte: IBGE (1942).

Essas habitações se situariam ao norte da Avenida Paranaíba, próximas à zona industrial, conforme determinaria Attilio Corrêa Lima (1937/1942) - o que refuta a alegação ainda hoje ativa de que o urbanista não teria previsto, em seu plano, uma área habitacional para os trabalhadores. Posteriormente, o que seria uma ampla zona residencial operária se subdividiria em regiões como a Vila Militar e o Bairro Popular e neste último, aliás, seria comum a cessão gratuita de lotes para servidores e operários nos primeiros anos de Goiânia. Como salientaria uma reportagem intitulada "O operariado desta Capital está de parabéns", a medida evitaria "prejuízos aos que, com o suor do seu rosto, e depois de privações de toda sorte, conseguiram acumular pequenas economias", sendo assim "uma prova do nosso apreço à operosa classe operária desta Capital” (O OPERARIADO..., 1935, p. 1). Todavia, sem 
mencionar a intensa especulação imobiliária ${ }^{34}$, haveria requisitos para angariar o benefício, como arcar com as custas documentais e efetuar a construção em prazo determinado, além da existirem condicionantes como a distância e até normas edílicas que, apesar de ali serem menos exigentes, poderiam inviabilizar a construção diante dos parcos recursos de expressiva parcela dos trabalhadores - como assinalariam os depoimentos de Pedro Meireles e João Tomé de Aquino.

Nesse tempo, o Governo do Estado dava lotes de graça, com prazo de dois anos para se construir e eu não podia nem requerer um lote porque não tinha cinco mil e duzentos réis para requerer o lote. E quando as pessoas que podiam, que requeriam que o agrimensor fosse tirar da Av. Anhanguera para baixo, o sujeito dizia: Que é que eu quero com lote aqui? Não quero lote aqui, não. Da Anhanguera para cima eu aceito, mas para baixo, não. E está aí. Depois de dois anos, eu comprei o direito de um lote [...] (MEIRELES apud GOIÂNIA, 1985, p. 148)

Ah, aqui estavam dando os lotes, né? Dava lote pra construir e eu não podia. Um falou: Oh, tão dando lote no Bairro Popular, aí. Você não quer pegar um lá? Pra fazer uma casa lá? Fazer com o que? Qual dinheiro? Não posso pegar. E muitos pegaram, fizeram o alicerce, parede, essas coisas. Parou, não podia terminar a casa. Acabou vendendo pra outro porque não podia terminar, né? Vendeu pra outro, outro recebeu a escritura e terminou. (AQUINO apud WIEDERHECKER; CHAVES; PEREIRA, 1987, p. 16-17)

Logo, construir nas imediações do córrego Botafogo - local de ocupação tão antiga quanto os serviços preliminares da construção da nova capital -, de maneira alheia ao plano, se apresentaria como a principal (ou a única) opção para muitos. Majoritária parte das habitações operárias, porém, não necessariamente se conformaria à semelhança física (e simbólica) de algumas das casas mais famosas da região: essas últimas, embora também carregadas de precariedades, deteriam um caráter provisório e seriam concebidas, sobretudo, para abrigar temporariamente funcionários do alto escalão do governo e das obras - e, aliás, com projetos atribuídos a Attilio Corrêa Lima (que ali igualmente residiria por um período), fazendo lembrar uma passagem do relatório de Armando de Godoy, onde o engenheiro afirmaria que "uma casa de madeira, com um só aposento, desde que seja bem estudada arquitetonicamente, pode ser um motivo de beleza para uma cidade" (GODOY, 1933/1943, p. 215). Isto posto, as residências contingenciais - de melhor acabamento, por assim dizer -, assumiriam um papel alegórico particular, passando a ser veiculadas como indícios de um quadro de carência compartilhado por todos, em prol de um bem maior - como justificaria um relatório da Firma Coimbra Bueno, conquanto também assinalasse a existência de diferentes

\footnotetext{
${ }^{34}$ Lévi-Strauss chegaria a perpassar a questão em Triste trópicos. Segundo o francês, "houve mesmo, no início, em 1935-36, um período em que se oferecia terra como prêmio aos compradores que concordassem em pagar as despesas de escritura. Pois os notários e especuladores eram os primeiros ocupantes" (LÉVI-STRAUSS, 1955/1957, p. 128).
} 
tratamentos -, ao mesmo tempo que, com o rápido caminhar das obras, marcaria um passado que aparentemente se encontraria superado.

Só o alojamento, para uma população operária que já orça em mais de 1.000 pessoas (operários, suas famílias e agregados), num local inteiramente virgem, onde há 3 anos não existia uma única morada, - só esta parte, a ser executada de acordo com as exigências mínimas de um padrão moderno e tolerável de vida, exigiria quase tanto quanto se gastou com a totalidade das obras. A maioria dos ranchos operários custou menos de $100 \$ 000$ cada. As casas de madeira, feitas com rapidez, sempre para satisfazer necessidade imediata de alojamento do pessoal mais classificado das obras, foram feitas com a mais restrita economia e constituem o mínimo abrigo que se poderia tolerar para viver. Todos, desde o mais graduado até o mais humilde dos auxiliares desta obra, se conformaram com o desconforto e o sacrifício de toda a espécie, que ela vem exigindo. (COIMBRA BUENO \& CIA LTDA., 1936 apud ALVARES, 1942, p. 71-72)
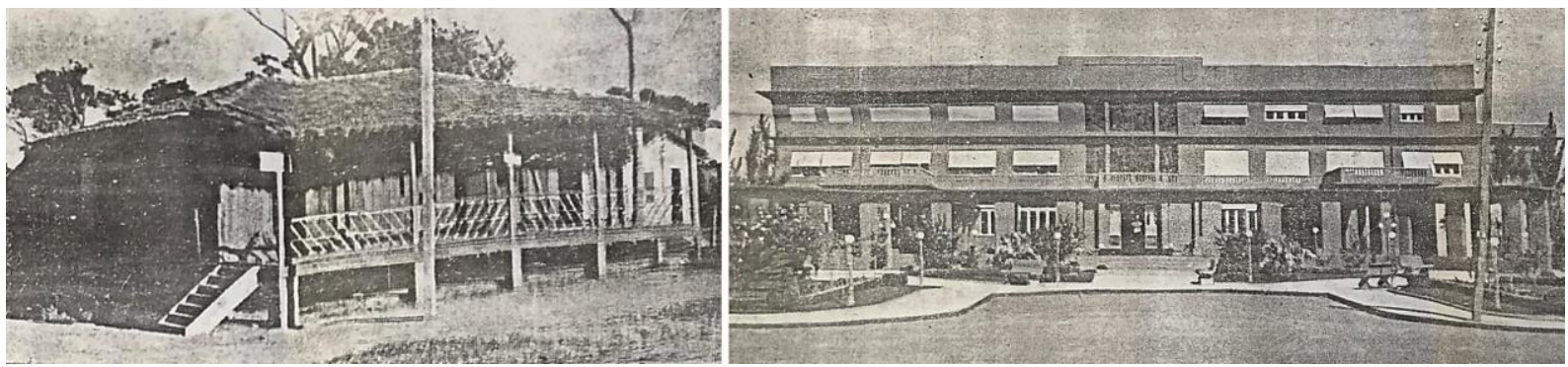

Figura 56: Casa provisória e Palácio do Governo. "Ontem - A primeira residência do interventor Pedro Ludovico em Goiânia, nos primórdios da construção da cidade" (esq.); "Hoje - O Palácio das Esmeraldas, residência oficial do Chefe do Governo, e onde funciona o gabinete da interventoria” (dir.). Legendas da publicação.

Autoria desconhecida. Fonte: Revista da Semana (1942)/Acervo da SEPLANH, modificado pelo autor.

Em contrapartida, como se numa cidade à parte (e de dinâmica própria), considerável parcela das habitações na região do Botafogo se estabeleceria essencialmente muito aquém das exigências mínimas que as residências de alvenaria ou mesmo as casas de madeira “oficiais” poderiam prefigurar. Se nos idos de 1935 Corrêa Lima (1935/1942, p. 56) já alertava acerca de "construções em desacordo com as boas regras construtivas, como sejam: emprego de minerais para alicerces como o denominado de 'Tapiocanga'; adobe em panos de parede e assentamento de tijolos com argila", haveria registros de habitações ainda mais precárias, como aquelas basicamente construídas com palha. Diante do quadro, José Júlio Lima (apud TELES, 1986/2012), ao ver aquelas numerosas casas, imediatamente lembraria de Canudos, sob a luz da descrição de Euclides da Cunha em Os Sertões.

Não se distinguiam as ruas. Substituí-as dédalo desesperador de becos estreitíssimos, mal separando o baralhamento caótico dos casebres feitos ao acaso, testadas volvidas para todos os pontos, cumeeiras orientando-se para todos os rumos, como se tudo aquilo fosse construído febrilmente, numa noite, por uma multidão de loucos... [...] Canudos surgia com a feição média entre a de um acampamento de guerreiros e a de um vasto kraal africano. A ausência de ruas, as pranças que, à parte a das igrejas, nada mais eram que o fundo comum dos quintais, e os casebres unidos, tornavam-no como vivenda única, amplíssima, estendida pelas colinas, e destinada a abrigar por pouco tempo o clã tumultuário de Antônio Conselheiro. (CUNHA, 1902/2010, p. 155-156) 
Esses exemplares residenciais, apesar de se assumirem como um elemento marcante aos olhos dos pioneiros, pouco conformariam as primeiras narrativas visuais. Não que fossem raros os registros - Alois Feichtenberger, por exemplo, muito se deteria nessas supostas contradições, tirando abundantes fotografias na região do Botafogo - mas que, principalmente pela potencial contrapropaganda que poderiam representar, enfrentariam um processo de ocultamento. Dentre as publicações pioneiras - e sem considerar registros de estabelecimentos não residenciais -, apenas o livro organizado pelo Instituto Brasileiro de Geografia e Estatística (1942) traria uma captura aérea da área onde, embora de forma pouco detalhada, é possível ver tanto as casas provisórias empreendidas pelo Estado quanto as habitações autoconstruídas pelos operários. Décadas depois - e para além das estremas temporais da dissertação -, num momento em que Goiânia já se apresentava consolidada, observa-se que outras imagens da época passariam a ser veiculadas com maior frequência, sendo absorvidas pela memória iconográfica da cidade.

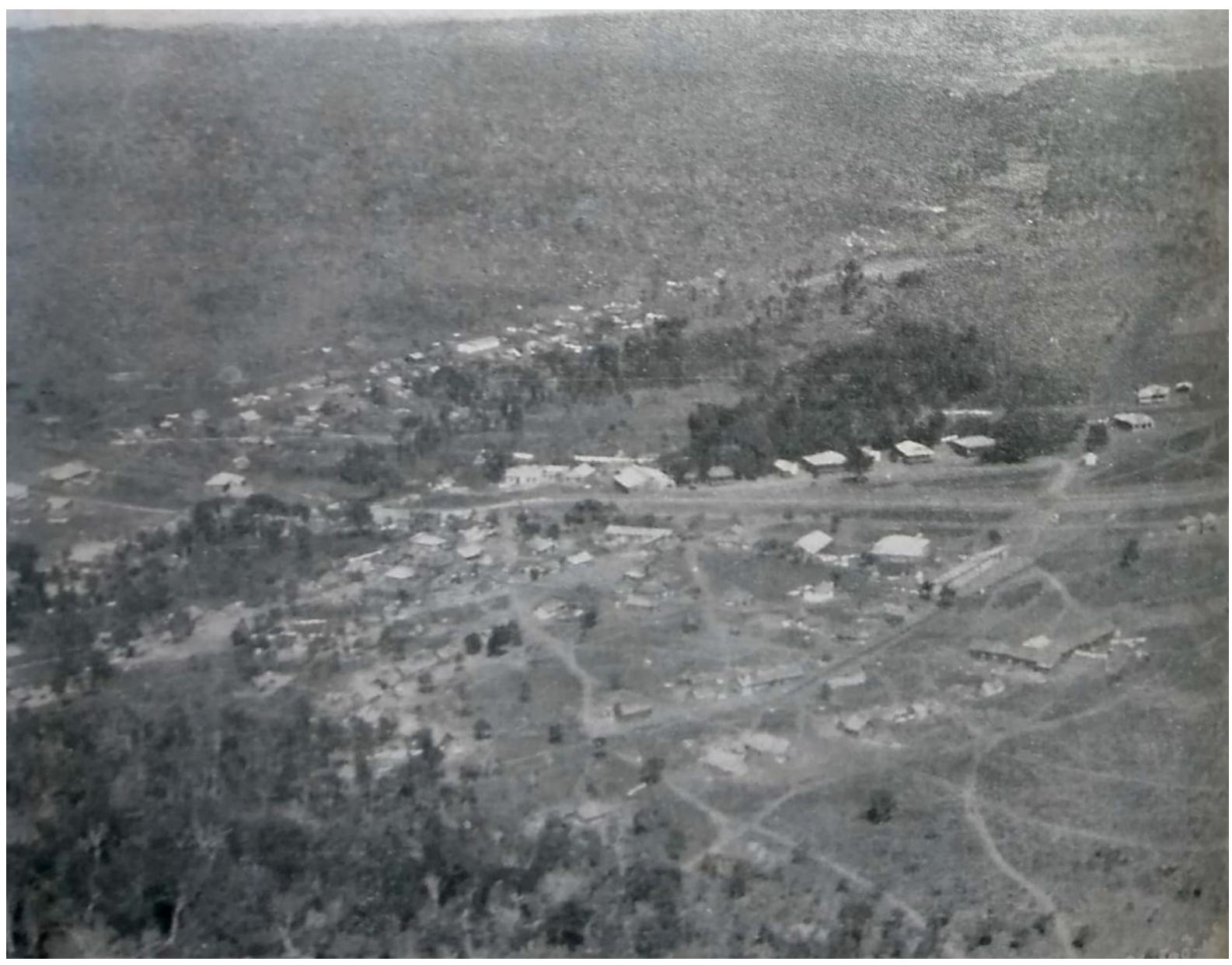

Figura 57: "A pequena cidade improvisada pelos trabalhadores que construíram Goiânia (Bairro Botafogo)". Legenda da publicação. Escola de Aviação Militar/Antônio Pereira da Silva. Fonte: IBGE (1942). 


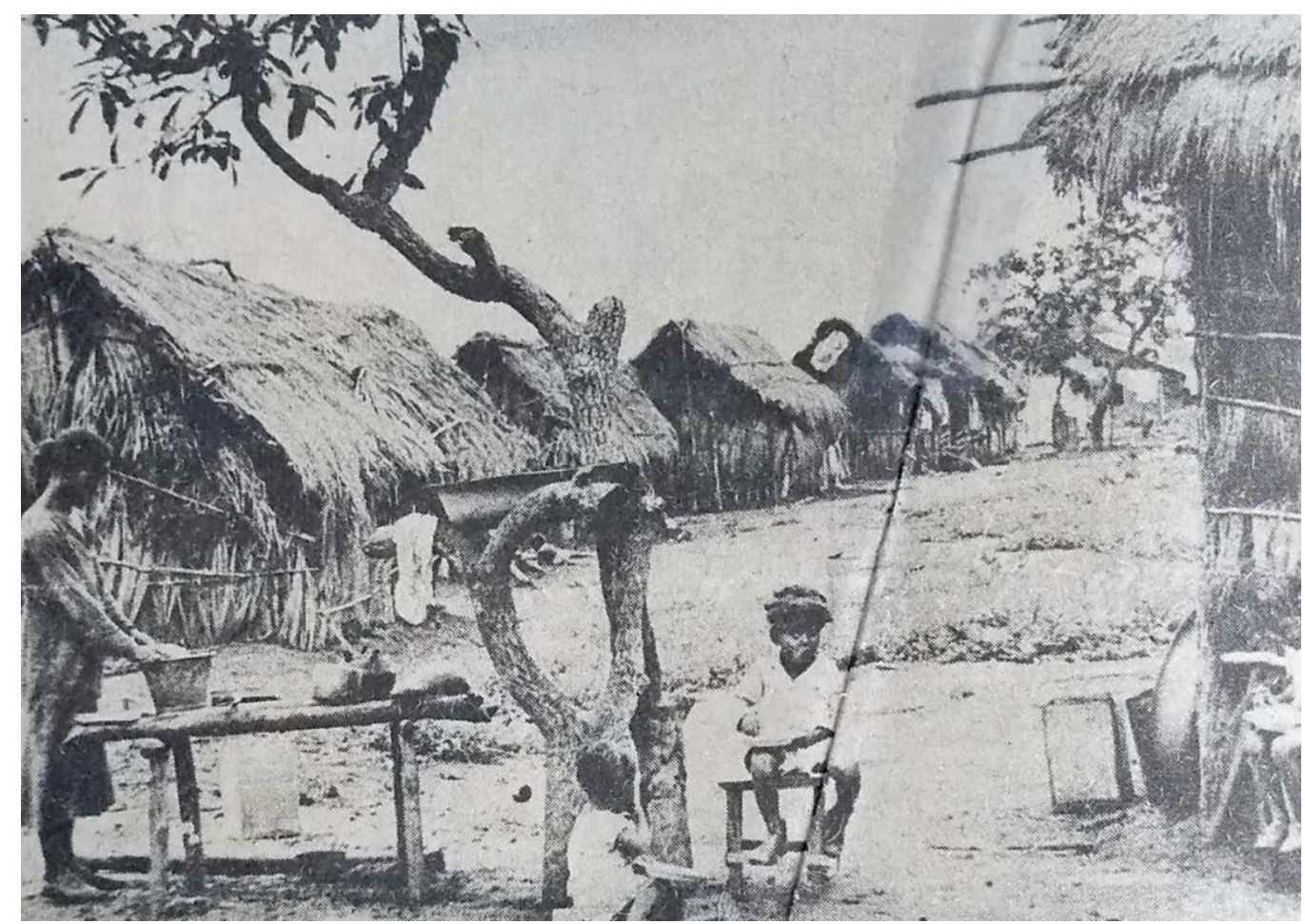

Figura 58: Casas na região do Botafogo. "Os migrantes vinham de todas as partes. No Norte, do Nordeste, do interior do Estado e de Minas Gerais. Alojavam-se como podiam. Buscavam dias melhores". Legenda da publicação. Alois Feichtenberger. Fonte: O Popular (1976).

No momento da construção, entretanto, denotando o empenho em manter a ordem na nascente capital, chegaria a ser afirmar que "Goiânia não terá favelas" (GOIÂNIA..., 1948, p. 3). Deste modo, persistindo as dificuldades de se conseguir soluções adequadas de moradia em Goiânia e Campinas, se preveriam novas áreas habitacionais especialmente voltadas para operários, posteriormente à aprovação do plano urbanístico de 1938 - o que anteciparia algumas de suas primeiras modificações substanciais. Segundo o pioneiro Claudomiro Freitas, essa iniciativa supostamente teria partido de um apelo de Getúlio Vargas, naquela que seria a primeira visita de um presidente a Goiás, no ano de 1940.

Passando dentro do Botafogo viu [Getúlio Vargas] as condições de moradia daquela
turma, mandou que o Pedro Ludovico, que era o governador, o interventor do
Estado, aliás, pediu que loteasse uma área para tirar os operários daquelas más
condições que estava lá na Vila Nova, lá no Botafogo. E aonde foi feito esse
loteamento aqui. Para tirar o pessoal daquelas condições, daquele acampamento. [...]
(FREITAS, C. F. apud MATTOS, S. C., 2008, p. 52)

Dentre os novos bairros, o principal seria denominado Vila Nova, imediatamente a leste do córrego Botafogo. Embora se apresentasse como uma nova oportunidade aos trabalhadores, também com cessão gratuita de lotes, haveria um verdadeiro imbróglio por melhores condições de vida na região.

Sua população, na quase totalidade constituída de operários, hoje, mais do que nunca atravessa uma fase de desalento e de aperturas, por haver a Secretaria de Economia Pública proibido que sejam ali abertas cisternas mas sem primeiro haver 
estendido até lá os canos que conduzem e donde jorram água, esse liquido precioso e tão indispensável à existência. Para agravar mais a situação dos que vivem e se entregam à labuta cotidiana de seus afazeres, o Departamento acima aludido, não permite, também, a reconstrução dos prédios existentes naquele bairro, por serem eles, em grande parte, de aspecto antiestético e avelhantado. Acontece, porém, que a maioria da população de Vila Nova, formada desses proletários que construíram Goiânia, não pode, em absoluto, edificar residências modernas e vistosas, como as do centro da cidade [...] (VILA..., 1945, p. 1)

Assim, o que se verificaria no princípio do bairro Vila Nova seria, em certa medida, a persistência de precariedades - permeada de embates e negociações com o poder público. Adolfo Boari (apud GOIÂNIA, 1985, p.20), por exemplo, revelaria que "tinha casinha lá só de três paus, como um tripé coberto com saco de cimento vazio e ficava ali tomando conta do lote que ganhou. Depois, [...] vendiam o lote e iam embora”. Semelhantemente, a pioneira Leda Vilela, que chegara a Goiânia em 1943, indicaria alternativas encontradas por muitos que precisavam se estabelecer com os meios possíveis.

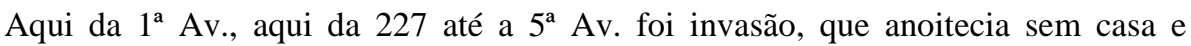
amanhecia o pessoal já morando, construía. Nós mesmos construímos lá uma cada de três cômodos, um barracão de três cômodos numa noite, bem feito, alto, numa noite. Numa noite construímos, quando amanheceu o dia, mais ou menos sete e meia, oito horas, o fiscal passou, a gente já morava dentro. Era rápido, num instantinho, parecia formiguinha trabalhando, do mais velho ao pequenininho, carregando água, amassando barro, fazia aqueles buracos assim com terra fofa, amassava barro e cada um servia de servente, o pedreiro lá trabalhando a noite toda. Amanhecia já prontinha, só faltava o reboco e o acabamento. A família já estava morando dentro. (VILELA apud MATTOS, S. C., 2008, p. 63)

Curiosamente, na Vila Nova, até mesmo casas empreendidas pelo Estado teriam condições pouco alinhadas àquelas enunciadas na construção de Goiânia. Segundo apontariam Ana Paula Koury e Nabil Bonduki, no inventário Os pioneiros da habitação social no Brasil, um núcleo residencial promovido pela Fundação Casa Popular, no ano de 1947, seria entregue sem instalações básicas.

Em Goiânia, a FCP adotou o tipo Sorocaba, uma unidade habitacional de pequena dimensão, com dois quartos. Como em vários outros núcleos da FCP, este foi entregue sem infraestrutura. Segundo depoimentos de antigos moradores, o conjunto permanecia inacabado quando foi ocupado. $\mathrm{O}$ abastecimento de água dependia de uma fonte localizada a 600 metros do local e, para melhorar o saneamento, os moradores tiveram de se organizar para instalar cisternas e fossas. Além disso, o cômodo destinado ao sanitário foi entregue pela construtora sem peças sanitárias; o banheiro era apenas um buraco no quintal. A luz elétrica e a pavimentação foram implantadas apenas alguns anos depois da ocupação das casas. (BONDUKI; KOURY, 2014, p. 333)

Em meio a tantos óbices e discrepâncias na construção da nova capital - de Campinas a Vila Nova, do Bairro Popular ao Setor Central -, então se atribuiria um significado próprio às casas ao sentenciar que estas, indistintamente "grandes e pequenas, palácios e residências" (A TELHA..., 1943, p. 1), carregariam consigo a representação do 
esforço, do sacrifício e da confiança em Goiânia - mesmo diante da distância em relação aos centros produtores e das anormalidades provocadas pela Segunda Guerra Mundial, conforme indicaria uma reportagem da Folha de Goiaz. Pois, em que pesasse a crise habitacional que se tornava cada vez mais avassaladora, em Goiânia se encontraria uma lição de patriotismo e fortaleza "de quem, vindo de outra parte de Goiaz mesmo ou de fora dele, aqui veio bater os esteios de sua casa, aqui veio construir a sua máquina de morar" (A TELHA..., 1943, p. 1).

Neste mesmo texto, para além da referência um tanto quanto singular a Le Corbusier - onde o arquiteto seria apontado como autor da mais completa e perfeita definição de casa e, em seguida, se associaria a palavra "máquina" a termos como "amorável", "ternura" e "afeto" (A TELHA..., 1943, p. 1) -, outro aspecto ainda chamaria a atenção: a identificação de uma verticalização latente, um desejar ver, num momento em que não era perceptível "a escalada do alto, a aventura para cima, a arremetida na direção das nuvens" (A TELHA..., 1943, p. 1). Diante de um símbolo tão figurativo de progresso e ainda inexistente nos primeiros anos da nova cidade, a ausência de arranha-céus em Goiânia seria preenchida por representações gráficas permeadas por um horizonte de expectativas. Uma capa comemorativa do jornal $O$ Popular datada em 1939 - na ocasião em que se completava seis anos desde o lançamento da pedra fundamental da nova urbe -, a inscrição "Goiânia, cidade do futuro" viria acompanhada por carros, trens, viadutos e um pattern de edifícios, todos desenhados. Já nas solenidades da inauguração oficial da cidade, três anos depois, ao fundo do palco do Cine-Teatro Goiânia se veria uma arte composta por marcos existentes - como a Escola Técnica e algo que remete ao Palácio do Governo - ao lado de blocos escalonados que sugeririam o avanço e o iminente crescimento vertical da cidade.
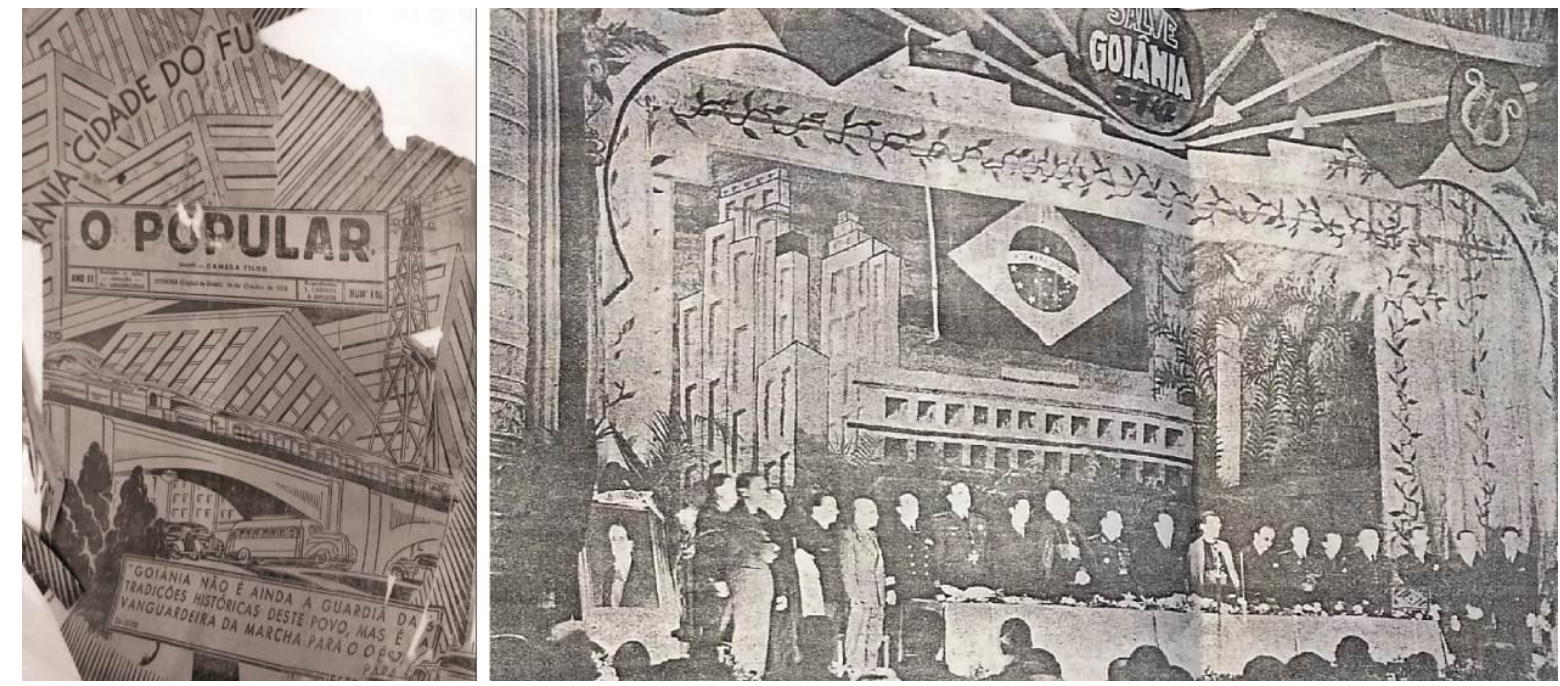

Figura 59: As representações de verticalização. Autoria desconhecida. Fonte: O Popular (1939)/Acervo do AHEG; Revista da Semana (1942)/Acervo da SEPLANH, modificado pelo autor. 
Outrossim, um jornal estrangeiro recuperado por Godinho (2013) chegaria a indicar que a torre da igreja Ateneu Dom Bosco seria considerada um arranha-céu na cidade, enquanto a maioria das construções de Goiânia possuíam no máximo três pavimentos. Sem embargo, o que se verificaria na sequência seria o esboço de um processo de verticalização e, à medida que Goiânia desvestia-se de sua pudica túnica provinciana e paramentava-se de metrópole, como metaforizaria Castro Costa (apud TELES, 1986/2012), o surgimento de edifícios em altura seria celebrado: a sede da Sociedade Goiana de Pecuária, por exemplo, reiteradamente estamparia páginas de jornais, seja despontando como o maior edifício de Goiânia em meados da década de 1940 (O MAIOR..., 1946), seja representando os virtuosos frutos da epopeia da construção da capital - em reportagens que já dedicariam um olhar retrospectivo à empreitada (GOIÂNIA..., 1949).

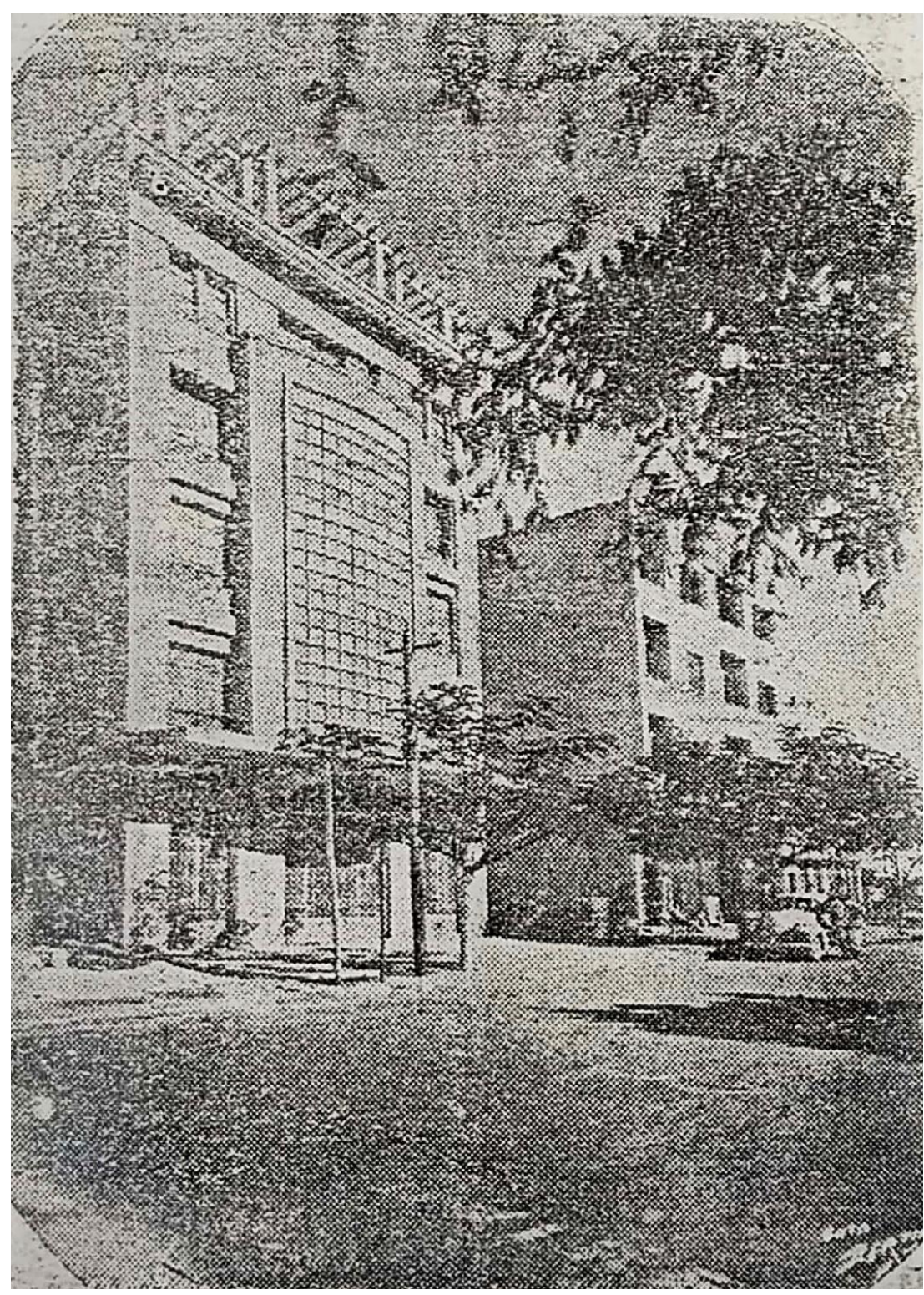

Figura 60: Sede da Sociedade Goiana de Pecuária. Sílvio Berto. Fonte: Folha de Goiaz (1946)/Acervo da SEPLANH. 
Com seus cinco pavimentos, de maneira estrita não se poderia considerar a sede da Sociedade Goiana de Pecuária um arranha-céu. Contudo, numa cidade ainda essencialmente horizontal, o prédio concebido por José Neddermeyer - engenheiro-arquiteto egresso da Escola de Engenharia Mackenzie (MENDES, 2017) - seria um dos importantes passos rumo à consolidação simbólica de Goiânia. O edifício, que chegaria a contar com abrigo antiaéreo (em tempos de guerra, exigia-se tal solução para construções de cinco ou mais pavimentos na nova capital), sinalizaria a crescente verticalização e adensamento da Avenida Goiás, bem como o estabelecimento da própria cidade. E essas facetas seriam realçadas pela fotografia de Sílvio Berto.

A tomada do edifício-sede, por exemplo, se ajustaria perfeitamente a uma captura de orientação horizontal. No entanto, para salientar os traços verticais da edificação, Berto optaria por um enquadramento parcial orientado verticalmente. Ademais, a deformação própria da correção de perspectiva, bastante comum em fotografias de arquitetura, provocaria um efeito de exagero óptico que daria ênfase à verticalidade e ao coroamento da edificação. De resto, à semelhança do registro do Grande Hotel, o italiano incorporaria à composição edifícios vizinhos, bem como os ramos de uma árvore - que fariam lembrar o emprego deste elemento por fotógrafos como Julius Schulman - e um veículo convenientemente disposto na Avenida Goiás. Não que carros fossem necessariamente raros em Goiânia pelos idos de 1946 (embora as bicicletas fossem o meio de transporte mais popular) mas, em meio às intencionalidades que permeiam o olhar fotográfico, Eleyson Rocha de Oliveira, que trabalhara com Berto como aprendiz de fotógrafo, forneceria pistas que nos permitem compreender que nem sempre as fotografias são tão fidedignas quanto se pressupõe.

Nós fazíamos vistas da cidade. Nós colocávamos a máquina, na Avenida Goiás, no
lugar certo, focalizava, tudo direitinho. Então nós convidávamos os donos de carro
da cidade para passarem naquele momento oportuno pra gente fotografar, porque
não havia tanto movimento de carro [risos]. Eles eram chamados, vinham, paravam
ali, naquela hora, né, e a gente batia. (OLIVEIRA, E. R., 2001)

Por fim, o Centro Cívico, como principal motivo da cidade, apresentaria os índices de uma capital que cada vez mais se assemelharia às imagens que lhe foram idealizadas. Síntese da cidade burguesa de Romero (1976/2005), com seus disciplinados jardins, amplas perspectivas e monumentais edifícios públicos - apesar da moderação em rebuscamentos -, a praça central de Goiânia já não era mais o esmerado desenho da Firma Coimbra Bueno ou o palco onde o carro de boi registrado por Feichtenberger se colocaria como protagonista, e sim a própria representação da civilização estabelecida em meio ao sertão. Suas feições impressionariam aqueles que lhe frequentavam, sobretudo os pioneiros advindos dos rincões 
do Brasil Central, segundo desvelaria Jussara Marques de Amorim - a primeira goiana a vencer o Miss Brasil.

Alegria maior ainda eram os passeios até a Praça Cívica que, com seus bonitos jardins, coloridos canteiros de papoulas (nunca mais vi papoulas no Brasil), fontes luminosas e o Palácio das Esmeraldas, formava um conjunto de contos de fadas aos meus olhos de menina, nascida em Itumbiara, onde dividira aqueles curtos anos de vida entre a cidade natal e a fazenda dos pais. (AMORIM apud GOIÂNIA, 1985, p. 251)

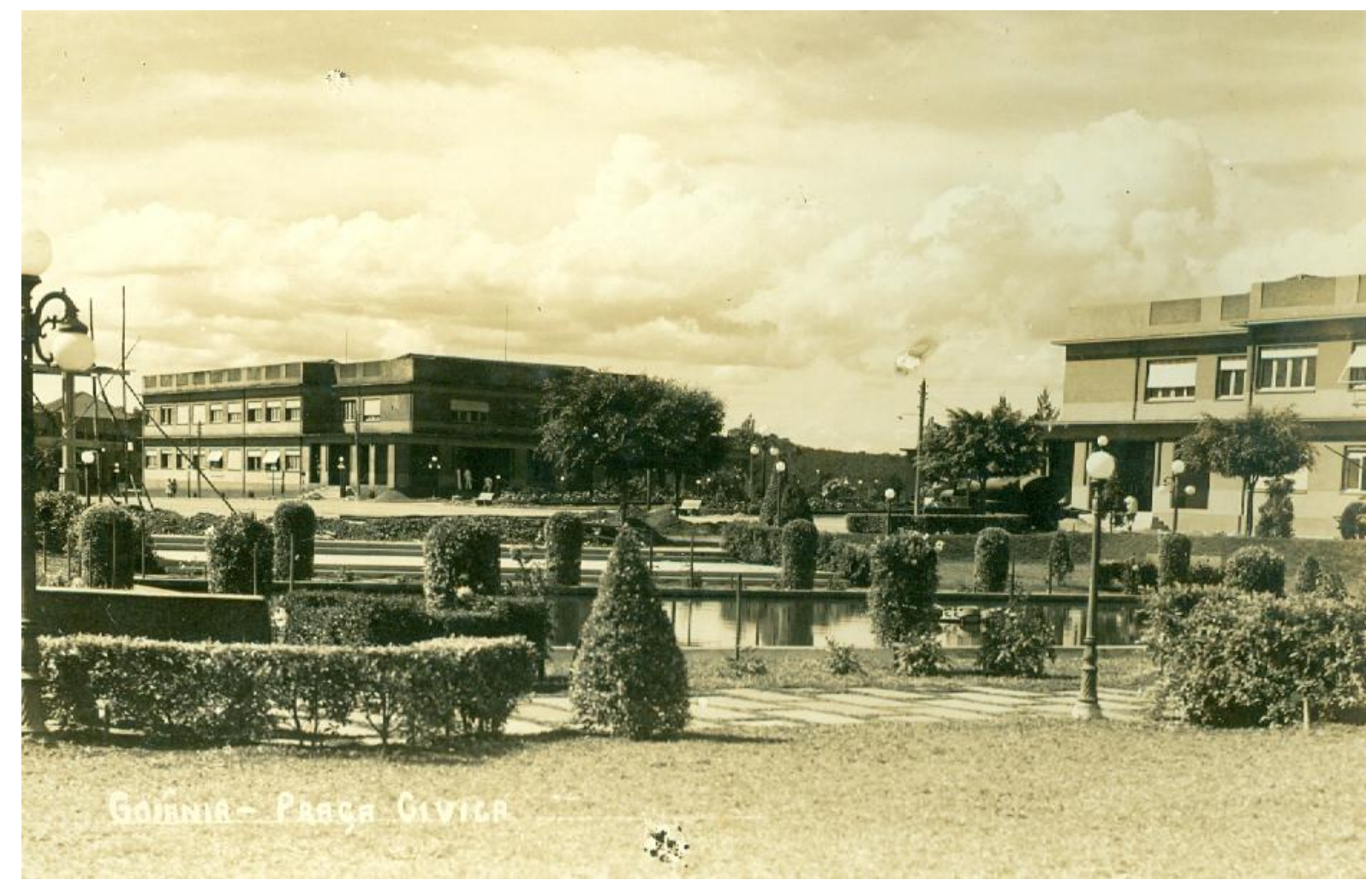

Figura 61: Praça Cívica. Foto do álbum: Goiânia, uma cidade por decreto. Goiânia-GO. Década de 1940. Haroutium Berberian. Fonte: Acervo MIS/GO.

Tal como o Grande Hotel e o Automóvel Club, o palácio do Centro Cívico seria privilegiado espaço da sociedade goianiense, de modo que seus famosos bailes de réveillon e garden parties, se por um lado revelariam a cristalização de determinados hábitos de sociabilidade, por outro indicariam que o tão aclamado sentimento de comunidade daqueles primeiros anos não necessariamente pressuporia a inexistência de cisões, já prefiguradas pela discrepância das condições habitacionais. Como afirmaria Adolfo Boari (apud GOIÂNIA, 1985, p. 19), quem frequentava essas festas "eram os maiorais, os doutores, funcionários públicos de grau, operário ficava pelas beiradas. As festas não eram pra operário" - que, por sua vez, procurariam outras atividades de lazer, inclusive em Campinas e imediações. Em contrapartida, dada a amplitude dos espaços e as funções ali abrigadas, no Centro Cívico se testemunhariam os grandes acontecimentos da cidade, a exemplo da visita do presidente Getúlio Vargas, a missa campal do Batismo Cultural e uma infinitude de eventos e 
demonstrações cívicas de colégios e corporações da capital, confirmando a vocação vislumbrada por Corrêa Lima, que a imaginara tomada pelo povo. As multidões, signos de grandes cidades e conquanto ainda pouco usuais na nascente urbe, cada vez mais se condensariam naquele que seria o ponto nodal de Goiânia.

De lá, aliás, através da icônica perspectiva fruto da concepção em patte d'oie, possivelmente se veria com maior propriedade o gradual crescimento da nova capital. As três avenidas convergentes que, para alguns, inicialmente mais pareceriam estradas em meio ao descampado, passariam a ganhar contornos citadinos com o asfaltamento, os flamboyants e as crescentes construções que paulatinamente interromperiam a malha alternativa dos "trieiros". Não por acaso, vistas como esta seriam empregadas em sequências de antes e depois, como no pôster do capítulo anterior, indicando um estado de concretude.

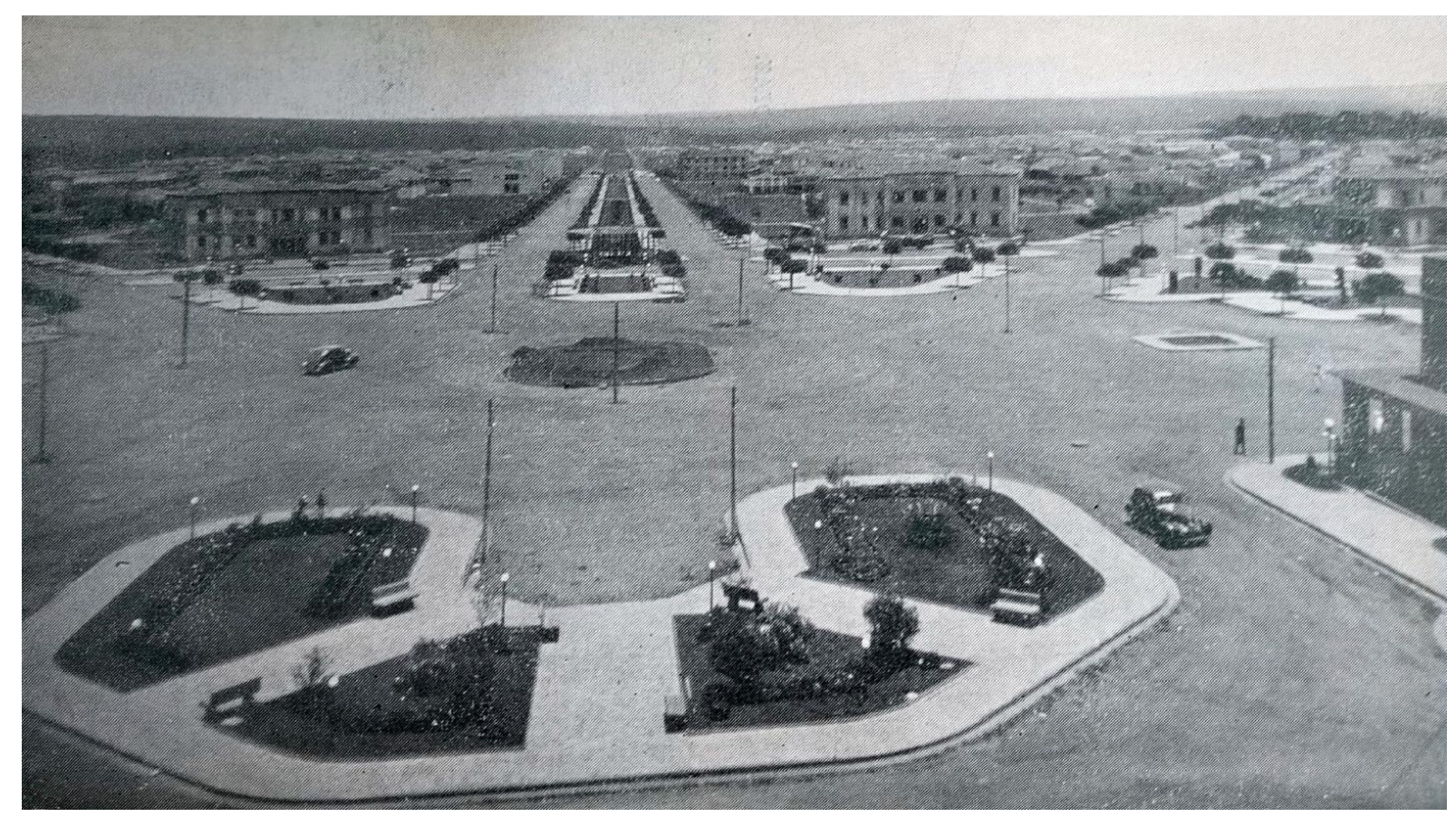

Figura 62: "Aspecto do Centro Cívico, onde se acham localizados todos os principais edifícios públicos de Goiânia". Legenda da publicação. Autoria desconhecida. Fonte: IBGE (1942).

Sob ângulo oposto, a partir do topo do relógio, ainda se teria uma perspectiva nobre do conjunto arquitetônico do Centro Cívico, compreendendo o coreto, o obelisco (depois demolido), a Secretaria Geral, o Fórum e o Palácio do Governo - que posteriormente seria denominado Palácio das Esmeraldas, em virtude de seu acabamento em pó de pedra de tonalidade verde que, em princípio, decorreria de um anseio imagético ${ }^{35}$. No entanto, a mesma orientação permitiria perceber que, para além dos edifícios públicos, o que constava nos

\footnotetext{
${ }^{35}$ De acordo com relatório da Firma Coimbra Bueno, o revestimento da fachada seria, "pela sua originalidade, um elemento de divulgação do Estado, chamando-se 'CASA VERDE', a exemplo de 'Casa Rosada' - Argentina, da 'Casa Branca' - Estados Unidos da América do Norte” (COIMBRA BUENO \& CIA LTDA., 1936 apud MONTEIRO, O. S. N., 1938, p. 468).
} 
mapas como Setor Sul ainda era, na verdade, um cerrado praticamente intocado - numa conjuntura que só se alteraria a partir da década de 1950, com as primeiras casas do bairro. Em meio à construção de Goiânia, nada mais metafórico que o coração administrativo de Goiás disposto exatamente entre pomposas vias que lembrariam o além-mar e o selvático descampado do sertão, como as próprias amálgamas que permeariam a capital e o estado ao longo daquelas décadas de profusas dialéticas.

Os bairros mais próximos ao centro, sem citar os da periferia, na verdade, só existiam nos mapas. Para o sul, além do Palácio, era aquele cerradão cortado por ruas poeirentas, uma casa aqui, outra ali. $\mathrm{O}$ mesmo visual do lado oeste, porque depois do Ateneu Dom Bosco, o setor valorizado de hoje não tinha mais que alguns barracões nos fundos dos lotes. (MENDONÇA, C., apud GOIÂNIA, 1985, p. 174)

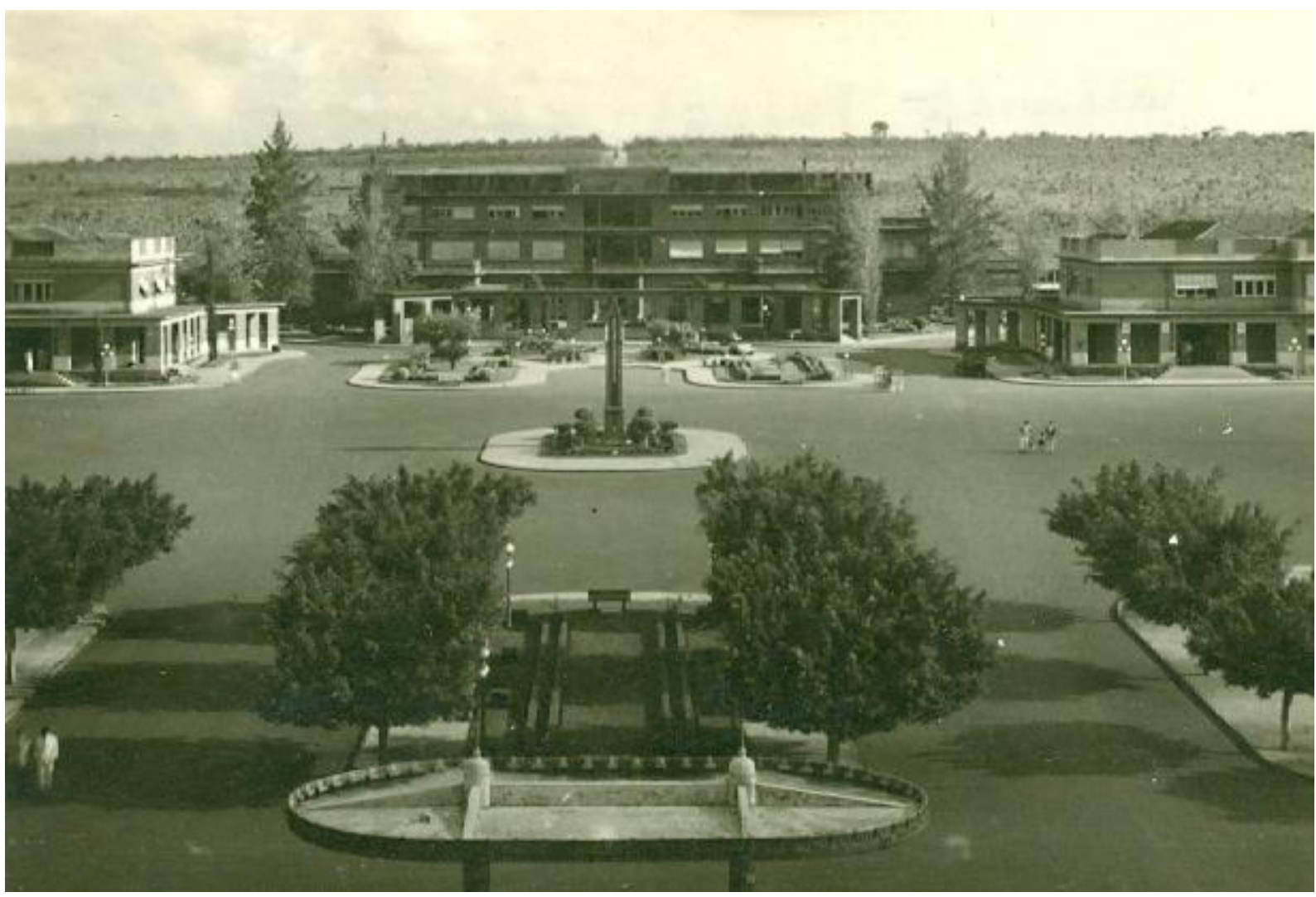

Figura 63: Palácio do Governo e Praça Cívica. Foto do álbum: Lembranças de Goiânia, "a capital caçula". Goiânia-GO. Década de 1940. Sílvio Berto. Fonte: Acervo MIS/GO. 


\section{Considerações finais}




\title{
CONSIDERAÇÕES FINAIS
}

\begin{abstract}
Por que a cidade então? Essencialmente porque constitui um "quadro conveniente", um observatório privilegiado. Mundo de contrastes sociais, onde as hierarquias se afirmam de maneira mais estruturada e mais refinada ao mesmo tempo, ela fornece um campo privilegiado para as controvérsias da história social. Lugar de exercício do poder administrativo que se envolve no controle quantificado de homens e produtos, é local de acumulação do arquivo. É, enfim, o microcosmo onde, com todos os planos da realidade se aproximando, as relações explicativas que de outra forma seriam imperceptíveis porque demais distorcidas se dão a ler. (LEPETIT, 1996, p. 21-22)
\end{abstract}

Goiânia, primeira capital planejada do Brasil no século XX e filha de um momento bastante particular, é um rico objeto cujo olhar à interconexão entre a cidade e as ideias ao longo de sua construção, entre leituras e discursos, permite-nos apreender o meio urbano, ao invés de locus de conflito, como arena de acomodação - numa "combinação inconstante de perspectivas, com o mais moderno e ocidental por vezes aparecendo gasto pelo manuseio e com o mais venerável, e até mesmo o mais exótico" (MORSE, 1984/1995, 221). Essas singularidades, como vimos, se devem aos meios nos quais as dinâmicas ali se conduziriam, diante de um jogo de desenvolvimento heterônomo e autônomo que, em última instância, implicaria na concomitância ou mesmo na antecedência de determinados ideários ou climas culturais em relação aos processos ou objetos que dizem respeito, como sugere Gorelik (1999).

Poderíamos entender que este nexo se apresentaria especialmente potencializado no complexo cenário de transformações que perpassa as décadas de 1930 e 1940: o fim da Primeira República com a Revolução de 30 e o deslocamento de poder que daí decorre em Goiás e no Brasil, com mudanças políticas determinantes; as dinâmicas distintas que se esboçariam na sociedade, mais uma vez em âmbito regional e nacional, prefiguradas pelos processos de urbanização e industrialização, com a crescente incorporação de contingentes rurais; o quadro de novas relações regionais, tanto em termos físicos - como através da expansão do sistema ferroviário e aeroviário - quanto em termos culturais - intrinsecamente envolto num movimento do (re)engendramento das identidades nacional e local; a sedimentação do urbanismo como campo de reflexão e prática profissional, paulatinamente inserindo-se no eixo de debate e ação pública/política no estado e no país; a maturação de novas linguagens arquitetônicas, bem como as novas formas de produção na construção civil; todos estes aspectos, num mesmo diapasão, reverberariam em Goiânia mediante um processo permeado de simultaneidades particularmente amplificadas pelas transições.

Estabelecer um olhar à construção da nova capital de Goiás, portanto, é estabelecer um olhar às sínteses de um largo movimento não apenas abstratamente consumado, mas 
vivenciado, interpretado e moldado. Nesse sentido, a leitura da cidade, sem limitar-se às indissociáveis noções de artefato e campo de forças e assumindo as representações como elementos preponderantes para a consolidação física e simbólica de Goiânia, possibilita-nos vislumbrar operações e diálogos que multiformemente atravessam os tempos e afloram de modo próprio na implantação de uma cidade nova no coração do país, com todos os anseios e carências que isto pressupõe.

O afã de progresso, posto como marca de um grupo político em ascensão e, porém, similarmente corolário do questionamento às persistentes memórias da decadência e atraso, encontraria na ideia de uma nova capital uma via privilegiada. Goiânia, assim, seria concebida em meio aos discursos de modernidade, seja a partir de um plano fruto da técnica, que idealizaria uma paisagem condizente aos novos tempos almejados; seja a partir das feições arquitetônicas que se distanciariam dos traços coloniais ou ecléticos que remeteriam à velha capital, vista como estagnada; seja a partir da iminente modernização que uma nova capital potencialmente exprimiria e irradiaria. Concomitantemente, à medida que as obras do novo centro administrativo avançavam, o próprio meio urbano alimentaria representações que, por sua vez, traduziriam e mediariam a relação estabelecida entre a cidade e seus habitantes e visitantes, através de discursos textuais ou não.

Em suma, a cidade e suas representações se produziriam reciprocamente e, nesta perspectiva, as visões de progresso adviriam da iniciativa de romper um status quo com a transferência da capital, de determinados aspectos físicos e sociais que já se consolidavam na urbe ou, ainda, de um horizonte de expectativas que cada vez mais se distanciava do espaço de experiência - o que Koselleck (1979/2006) atribui à modernidade. Esses referenciais próprios abasteceriam a surpresa de se deparar, em pleno sertão, com um núcleo urbano moderno - no sentido lato do termo -, mas também reservariam potenciais quebras de expectação.

Por outro lado, em meio ao engendramento simultâneo, presumivelmente os discursos modernizantes que deram origem à cidade não anulariam as supostas contradições. Outras facetas da nova capital apresentariam os limites da modernidade enunciada, ora observadas sob a herança de estigmatizadas imagens de Goiás (capazes de relativizar o empreendimento), ora sob a luz de uma perspectiva cética (onde, diante das precariedades presentes ao longo da construção da nova capital, as leituras se amparariam num presente tangível). Sem embargo, tais visões, em que pese enfrentarem determinadas operações de ocultamento, por vezes assumiriam na trama discursiva uma ressignificação própria e, assim, nem sempre deporiam contrariamente aos brados de progresso. Não por acaso, eventualmente 
proviriam de enunciadores comuns, sobretudo como indícios de um estado de vicissitude em meio a tantos óbices - o que, em princípio, tornaria a empreitada ainda mais vitoriosa.

Isto posto, a cidade, nas condições de ideia, obra e concretude, detém uma complexidade que impõe percebê-la para além de categorias estanques e virtualmente opostas uma vez que, de diversas maneiras, haveria profusas interlocuções em sua construção - e mesmo após nosso recorte temporal. Em suma, tacitamente ou não, seriam indissociáveis o urbano e o rural, o moderno e o tradicional, o metropolitano e o provinciano, mediante relações que, no final das contas, seriam inerentes à própria modernidade (ou sua expansão). As coexistências, portanto, se condensariam nas interpretações da construção de Goiânia, ao mesmo tempo que se manifestariam na constituição de uma trama discursiva. A leitura dos discursos para além da textualidade da sedimentada matriz historiográfica representada pelas publicações pioneiras, e igualmente arrimando-se em documentos iconográficos - inclusive aqueles presentes nestas mesmas publicações -, bem como as (re)produções discursivas apresentadas em periódicos contemporâneos à construção da capital e as apreensões de pioneiros ou viajantes, permitiu-nos vislumbrar tessituras que revelam dialéticas de modo mais claro, tal como as intencionalidades que permeariam a construção de narrativas sinalizadas pelo emprego de fotografias de acordo com fins determinados ou mesmo a própria confecção desses registros, conscientemente ou não.

Nos limites deste trabalho, naturalmente não se pretendeu esgotar o debate prefigurado pela construção de Goiânia, transversal a muitos outros temas que, por si só, dariam (ou já resultaram em) pesquisas específicas. Nosso intento foi, sob as estremas das histórias urbana e cultural - ou quiçá através de uma perspectiva urbana da história cultural, nos termos de Peixoto e Gorelik (2016) - contribuir para a ampliação da historiografia goianiense e das cidades brasileiras (em especial as chamadas cidades novas, cujas gêneses reservam profusos pontos de contato com Goiânia) a partir de um prisma próprio, compreendendo a nova capital não somente como fruto de uma concepção urbanística regionalmente inédita moldada pelas mãos de conhecidos nomes da historiografia do urbanismo ou da política, mas como produto e produtora de representações que, conquanto não estanques, em certa medida se perpetuariam após suas primeiras décadas.

$\mathrm{Na}$ sequência, logo no início da década de 1950, Goiânia romperia o teto populacional de seu assentamento basilar e, a partir de então, quase octuplicaria o número de habitantes nas duas décadas seguintes. A cidade se expandiria de tal forma que, às vésperas da inauguração de Brasília, Jorge Wilheim (1960, p. 22) descreveria a nova capital de Goiás como um "centro urbano planejado" circundado por uma área muito grande e de crescimento 
"espontâneo" - expressão que deve ser tomada com cautela, mesmo que não haja consenso sobre as decisões urbanísticas que alterariam o plano original e conformariam os bairros implantados em seguida. Atualmente, com população estimada em mais de 2,5 milhões de habitantes na Grande Goiânia, o título de metrópole lhe parece adequado. Não obstante, como aponta Chaul (2009), as amálgamas persistem de modo que hoje, assim como ontem, não é pertinente (ou mesmo factível) eleger qual faceta melhor lhe exprime. Talvez por isso seja, como cidade e objeto de estudo, tão instigante.

Goiânia mesclava o urbano e o rural, expressava a modernidade e o progresso. Uma parcela da sociedade da época, que tinha voz na política local, escondia o fazendeiro por trás do profissional liberal. O médico, o advogado, o farmacêutico, o engenheiro, o bacharel etc., quase todos ligados à estrutura fundiária, procuravam, por si mesmos, ou por meio de seus representantes, uma mudança nos quadros da política estadual. Faziam crer que o 'velho' - os grupos políticos depostos - tinha cedido lugar a uma nova ordem, de novos homens, entre jalecos e leis, remédios e construções, que, assim, dirigiam o Estado orientados por uma nova mentalidade: mais progressista, mais moderna, mais dinâmica. Tratava-se de uma mentalidade urbana com os pés plantados em solo rural. Tal mesclagem (urbano rural) pode, até os dias atuais, ser notada nas várias facetas da cidade que se tornou Goiânia. [...] Goiânia viva, country, countrypira, sertaneja, carnavalesca, nenhum rótulo é maior que sua dimensão histórica, permeada de heterogêneas faces de um mesmo rosto. Qualquer rótulo será mera expressão de um mero pedaço de seu todo, de suas mesclagens culturais, de suas simbioses geradoras de talentos de sua gente. Goiânia tem útero macunaímico, formação geral entre o urbano e o rural, art déco, berrante sampliado em múltiplos tons. (CHAUL, 2009, p. 107-110). 
Referências 


\section{REFERÊNCIAS}

\section{Referências bibliográficas}

ACKEL, Luiz Gonzaga Montans. Attilio Corrêa Lima: uma trajetória para a modernidade. 2007, 342 f. Tese (Doutorado em Arquitetura e Urbanismo) - Faculdade de Arquitetura e Urbanismo, Universidade de São Paulo, São Paulo, 2007.

ALVARES, Geraldo Teixeira. A luta na epopeia de Goiânia: uma obra da engenharia nacional. Rio de Janeiro: Oficina Gráfica do "Jornal do Brasil", 1942.

ANDRADE, Carlos Roberto Monteiro de. A peste e o plano: o urbanismo sanitarista do engenheiro Saturnino de Brito. 1992. 282 f. Dissertação (Mestrado em Arquitetura e Urbanismo) - Faculdade de Arquitetura e Urbanismo, Universidade de São Paulo, São Paulo, 1992.

. A construção historiográfica da cidade e do urbanismo moderno no Brasil: o caso das cidades novas planejadas. In: PINHEIRO, Eloísa Petti; GOMES, Marco Aurélio A. de Filgueiras (Orgs.). A cidade como história: os arquitetos e a historiografia da cidade e do urbanismo. Salvador: Editora da Universidade Federal da Bahia, 2005. p. 73-90.

ARRAIS, Cristiano Alencar. Fronteira cultural e política nacional: a Revolução de 1930 em Goiás. Revista Fragmentos de Cultura - Revista Interdisciplinar de Ciências Humanas, Goiânia, v. 17, n. 5, p. 821-838, out. 2008.

Identidades modernas do plano urbano de Goiânia. Boletim Goiano de Geografia, Goiânia, v. 32, n. 2, p. 177-192, jul./dez. 2012.

Mobilidade discursiva: o periodismo político em Goiás. Goiânia: Editora UFG, 2013.

ARGAN, Giulio Carlo. A história da arte. In: História da arte como história da cidade. São Paulo: Martins Fontes, 2005. p. 13-72.

ARRUDA, Rogério Pereira de. Cidades-capitais imaginadas pela fotografia: La Plata (Argentina), Belo Horizonte (Brasil), 1880-1897. Belo Horizonte: Fino Traço, 2013.

ARTIAGA, Zoroastro. Monografia corográfica e histórica da nova capital de Goiaz. Goiânia: Escola Técnica de Goiânia, 1949.

BAYER, Patricia. Art Deco architecture: design, decoration and detail from twenties and thirties. Londres: Thames \& Hudson Ltd., 1999.

BENJAMIN, Walter. Pequena história da fotografia. In: Magia e técnica, arte e política: ensaios sobre literatura e história da cultura. São Paulo: Editora Brasiliense, 1987. p. 91-107.

BERMAN, Marshall. Tudo que é sólido desmancha no ar: a aventura da modernidade. São Paulo: Companhia das Letras, 1986.

BERNARDES, Genilda Darc. Considerações sobre o plano de Goiânia. In: SILVA, Luiz Sérgio Duarte da (Org.). Relações cidade-campo: fronteiras. Goiânia: Editora UFG, 2000. p. 155-180.

BERTRAN, Paulo. História da terra e do homem no Planalto Central. Eco-história do Distrito Federal: do indígena ao colonizador. Brasília: Verano, 2000.

BONDUKI, Nabil; KOURY, Ana Paula. Os pioneiros da habitação social no Brasil: volume 02. São Paulo: Editora Unesp; Edições Sesc São Paulo, 2014.

BRAUDEL, Fernand. História e ciências sociais: a longa duração. In: NOVAIS, Fernando A.; SILVA, Rogerio Forastieri da (Orgs.). Nova história em perspectiva volume 1. São Paulo: Cosac Naify, 2011. p. 86-121. 
BRUAND, Yves. Arquitetura contemporânea no Brasil. São Paulo: Perspectiva, 2016.

BURKE, Peter. Testemunha ocular: história e imagem. Bauru: EDUSC, 2004.

CAMPOS, Candido Malta. Os rumos da cidade: urbanismo e modernização em São Paulo. São Paulo: Editora SENAC, 2002.

CAVALCANTI, Lauro. Moderno e Brasileiro: a história de uma nova linguagem na arquitetura (1930-60). Rio de Janeiro: Editora Jorge Zahar, 2006.

CERTEAU, Michel de. A escrita da história. Rio de Janeiro: Forense Universitária, 2006.

CHARTIER, Roger. A história cultural: entre práticas e representações. Algés: Difel, 2002.

CHAUL, Nasr Nagib Fayad. A construção de Goiânia e a transferência da capital. Goiânia: Centro Editorial e Gráfico da UFG, 1988.

. Goiânia: a capital do sertão. Revista UFG, Goiânia, v. 11, n. 6, p. 100-110, jul. 2009.

Caminhos de Goiás: da construção da decadência aos limites da modernidade.

Goiânia: Editora UFG, 2010.

CORDEIRO, Narcisa. Goiânia: evoluções do plano urbanístico. Goiânia: Edição do autor, 1989.

; QUEIROZ, Normalice. Goiânia: embasamentos do plano original. Goiânia: Edição do autor, 1990.

CORREIA, Telma de Barros. Art Déco e indústria: Brasil, décadas de 1930 e 1940. Anais do Museu Paulista, São Paulo, v. 16, n. 2, p. 47-104, jul./dez. 2008.

COSTA, Gerson Castro. Goiânia: a metrópole do Oeste. Goiânia: Prefeitura Municipal, Assessoria Especial de Cultura, 1985.

COSTA, Helouise; SILVA, Renato Rodrigues da. A fotografia moderna no Brasil. São Paulo: Cosac Naify, 2004.

CUNHA, Euclides da. Os sertões. Rio de Janeiro: Centro Edelstein de Pesquisas Sociais, 2010.

DAHER, Tania. Goiânia, uma utopia europeia no Brasil. Goiânia: Instituto Centro-Brasileiro de Cultura, 2003.

DINIZ, Anamaria. Goiânia de Attilio Corrêa Lima (1932-1935): ideal estético e realidade política. 2007. 240 f. Dissertação (Mestrado em Arquitetura e Urbanismo) - Faculdade de Arquitetura e Urbanismo, Universidade de Brasília, Brasília, 2007.

O itinerário pioneiro do urbanista Attilio Corrêa Lima. Jundiaí: Paco, 2017.

ESPADA, Heloisa. Monumentalidade e sombra: a representação do centro cívico de Brasília por Marcel Gautherot, 2011. 224f. Tese (Doutorado em Artes Visuais) - Escola de Comunicação e Artes, Universidade de São Paulo, São Paulo, 2011.

FEBVRE, Lucien. Combates pela história. Lisboa: Editorial Presença, 1989.

FERNANDES, Ana. Urbanismo como política (1930-1945): formulações e experiências. In: REZENDE, Vera F. (Org.). Urbanismo na Era Vargas: a transformação das cidades brasileiras. Niterói: Editora da UFF; Intertexto, 2012. p. 47-69.

FERRO, Sérgio. O canteiro e o desenho. In: . Arquitetura e trabalho livre. São Paulo: Cosac Naify, 2006. p. 105-200.

FIGUEIREDO, Stela Horta. Dossiê: acervo Alois Feichtenberger. Goiânia: 2003.

FREITAS, Maria Luiza de. Modernidade concreta: as grandes construtoras e o concreto armado no Brasil, 1920 a 1940. 2011. 373 f. Tese (Doutorado em Arquitetura e Urbanismo) Faculdade de Arquitetura e Urbanismo, Universidade de São Paulo, São Paulo, 2011. 
GARDNER, George. Viagem ao interior do Brasil. Belo Horizonte: Editora Itatiaia; Editora da Universidade de São Paulo, 1975.

GIDDENS, Anthony. Mundo em descontrole. Rio de Janeiro: Record, 2002.

GINZBURG, Carlo. Olhos de madeira: nove reflexões sobre a distância. São Paulo: Companhia das Letras, 2001.

GODINHO, Iúri Rincon. A construção: cimento, ciúme e caos nos primeiros anos de Goiânia. Goiânia: Contato Comunicação, 2013.

GODOY, Armando Augusto de. A evolução das cidades e a urbs moderna. In: . A urbs e os seus problemas. Rio de Janeiro: Jornal do Commercio, 1943. p. 29-33.

Relatório apresentado ao Dr. Pedro Ludovico, interventor no Estado de Goiás, sobre a mudança da atual capital para Campinas. In: Janeiro: Jornal do Commercio, 1943. p. 211-229. A urbs e os seus problemas. Rio de

Os grandes resultados sociais e econômicos da obediência aos princípios do Urbanismo. In: A urbs e os seus problemas. Rio de Janeiro: Jornal do Commercio, 1943. p. 289-304.

A futura capital de Goiaz. In: INSTITUTO BRASILEIRO DE GEOGRAFIA E ESTATÍSTICA (Ed.). Goiânia. Rio de Janeiro: Serviço Gráfico do Instituto Brasileiro de Geografia e Estatística, 1942. p. 35-40.

GOIÂNIA. Prefeitura Municipal. Assessoria Especial de Cultura. Memória cultural: ensaios da história de um povo. Goiânia, 1985.

GOIÂNIA art déco: acervo arquitetônico e urbanístico - dossiê de tombamento. Goiânia: Instituto Casa Brasil de Cultura, 2010.

GONÇALVES, Alexandre Ribeiro. Goiânia: uma modernidade possível. Brasília: Ministério da Integração Nacional; Universidade Federal de Goiás, 2002.

GOODWIN, Philip. Brazil Builds: architecture new and old - 1652-1942. Nova Iorque: Museum of Modern Art, 1943.

GORELIK, Adrián. O moderno em debate: cidade, modernidade e modernização. In: MIRANDA, Wander Mello (Org.). Narrativas da modernidade. Belo Horizonte: Autêntica, 1999. p. 55-80.

- Imaginarios urbanos e imaginación urbana: para un recorrido por los lugares comunes de los estúdios culturales urbanos. EURE (Santiago), Santiago, v. 28, n. 83, p 125136, mai. 2002.

Das vanguardas a Brasília: cultura urbana e arquitetura na América Latina. Belo Horizonte: Editora UFMG, 2005.

; PEIXOTO, Fernanda Arêas. Introducción: Cultura y perspectiva urbana. In:

(Orgs.). Ciudades sudamericanas como arenas culturales. Buenos Aires: Siglo Veintiuno Editores, 2016. p. 11-19.

GRAEFF, Edgar Albuquerque. Goiânia: 50 anos. Brasília: MEC-SESU, 1985.

GUIMARÃES, Leonardo Dimitry Silva. Goiânia, a metrópole do sertão: representações visuais da capital goiana na Revista Oeste. URBANA: Revista Eletrônica do Centro Interdisciplinar de Estudos sobre a Cidade, Campinas, v. 10, n. 1, p. 250-268, jul. 2018.

HALBWACHS, Maurice. A memória coletiva. São Paulo: Editoria Vértice, 1990.

HOLANDA, Sérgio Buarque de. Raízes do Brasil. São Paulo: Companhia das Letras, 1995. 
INSTITUTO BRASILEIRO DE GEOGRAFIA E ESTATÍSTICA. Goiânia. Rio de Janeiro: Serviço Gráfico do Instituto Brasileiro de Geografia e Estatística, 1942.

KOSELLECK, Reinhart. Futuro passado: contribuição à semântica dos tempos históricos. Rio de Janeiro: Editora PUC Rio; Contraponto, 2006.

KOSSOY, Boris. Fotografia e história. São Paulo: Ateliê Editorial, 2014.

LACERDA, Aline Lopes de. A “Obra Getuliana” ou como as imagens comemoram o regime. Estudos históricos, Rio de Janeiro, v. 7, n. 14, p. 241-263, 1994.

LE GOFF, Jacques. História e memória. Campinas: Editora da UNICAMP, 1990.

O imaginário medieval. Lisboa: Editora Estampa, 1994.

A história nova. In: NOVAIS, Fernando A.; SILVA, Rogerio Forastieri da (Orgs.). Nova história em perspectiva volume 1. São Paulo: Cosac Naify, 2011. p. 128-176.

LEPETIT, Bernard. La ville: cadre, objet, sujet. Vingt ans de recherches françaises en histoire urbaine. Enquête, Marseille, n. 4, p. 11-34, 1996.

É possível uma hermenêutica urbana? In: ; ANGOTTI-SALGUEIRO,

Heliana (Org.). Por uma nova história urbana. São Paulo: Editora da Universidade de São Paulo, 2016. p. 173-189.

LÉVI-STRAUSS, Claude. Tristes trópicos. São Paulo: Editora Anhembi Limitada, 1957.

LIMA, Attilio Corrêa. Avant-projet d'aménagement et d'extension de la ville de Niterói au Brésil. Paris: Vicent, Fréal et Cie Editeurs, 1933.

Goiânia - a nova capital de Goiaz. In: INSTITUTO BRASILEIRO DE GEOGRAFIA E ESTATÍSTICA (Ed.). Goiânia. Rio de Janeiro: Serviço Gráfico do Instituto Brasileiro de Geografia e Estatística, 1942. p. 82-112.

Plano diretor da cidade. In: INSTITUTO BRASILEIRO DE GEOGRAFIA E ESTATÍSTICA (Ed.). Goiânia. Rio de Janeiro: Serviço Gráfico do Instituto Brasileiro de Geografia e Estatística, 1942. p. 45-56.

LIMA, Solange Ferraz de; CARVALHO, Vânia Carneiro de. Fotografia e cidade: da razão urbana à lógica do consumo: álbuns da cidade de São Paulo, 1887-1954. Campinas: Mercado das Letras, 2008.

LOBATO, Monteiro. Geografia de Dona Benta. São Paulo: Editora Brasiliense, 1995.

LYNCH, Kevin. A imagem da cidade. Lisboa: Edições 70, 1999.

MANSO, Celina. Goiânia: uma concepção urbana moderna e contemporânea - um certo olhar. Goiânia: Edição do autor, 2001.

A urbs e os seus problemas: uma lição de urbanismo na trajetória profissional de Armando Augusto de Godoy. 2018. 446 f. Tese (Doutorado em Arquitetura e Urbanismo) Faculdade de Arquitetura e Urbanismo, Universidade de Brasília, Brasília, 2018.

MARICATO, Ermínia; MORAES, Lúcia Maria. O mentirão, ou melhor, mutirão de Goiás. Lua Nova, São Paulo, v. 3, n. 2, p. 74-84, dez. 1986.

MARTINS, Carlos Alberto Ferreira. Arquitetura e Estado no Brasil. Elementos para uma investigação sobre a constituição do discurso moderno no Brasil: a obra de Lucio Costa 1924/1952. 1987. 225 f. Dissertação (Mestrado em História Social) - Faculdade de Filosofia, Letras e Ciências Humanas, Universidade de São Paulo, São Paulo, 1987.

MARTINS, Luciano. A Revolução de 1930 e seu significado político. In: A REVOLUÇÃO DE 30: SEMINÁRIO INTERNACIONAL, 1980, Rio de Janeiro. A revolução de 30: seminário realizado pelo Centro de Pesquisa e Documentação de História Contemporânea 
do Brasil (CPDOC) da Fundação Getúlio Vargas. Brasília: Editora Universidade de Brasília, 1983. p. 668-689.

MATTOS, Raymundo José da Cunha. Corografia histórica da província de Goiás. Rio de Janeiro: IHGB, 1979.

MATTOS, Sílvia Clímaco. Memória e cidade: lembranças do bairro da Vila Nova - 1930 ao presente. 2008. 151 f. Dissertação (Mestrado em História) - Departamento de História, Universidade de Brasília, Brasília, 2008.

MAUAD, Ana Maria. Na mira do olhar: um exercício de análise da fotografia nas revistas ilustradas cariocas, na primeira metade do século XX. Anais do Museu Paulista, São Paulo, v. 13, n. 1, p. 133-174, jun. 2005.

MAWE, John. Viagens ao interior do Brasil. Belo Horizonte: Editora Itatiaia; Editora da Universidade de São Paulo, 1978.

MEDEIROS, Enderson. Folha de Goiaz: o jornal e o seu tempo. In: ENCONTRO NACIONAL DE HISTÓRIA DA MÍDIA, 10., 2015, Porto Alegre. Anais do $10^{\circ}$ Encontro Nacional de História da Mídia. Porto Alegre: Universidade Federal do Rio Grande do Sul, 2015. Disponível em: <http://www.ufrgs.br/alcar/encontros-nacionais-1/encontrosnacionais/10o-encontro-2015/gt-historia-da-midia-impressa/folha-de-goiaz-o-jornal-e-o-seutempo>. Acesso em: 6 mar. 2019.

MEDEIROS, Wilton de Araujo. Goiânia metrópole: sonho, vigília e despertar (1933/1973). 2010. 338 f. Tese (Doutorado em História) - Faculdade de História, Universidade Federal de Goiás, Goiânia, 2010.

Jeronimo Coimbra Bueno - apontamentos iniciais sobre uma trajetória profissional. URBANA: Revista Eletrônica do Centro Interdisciplinar de Estudos sobre a Cidade, Campinas, v. 5, n. 2, p. 109-128, jun. 2013.

Discursos do urbanismo em Goiânia: da instrumentalização política ao surgimento de um campo profissional específico. In: SEMINÁRIO DE HISTÓRIA DA CIDADE E DO URBANISMO, 13., 2014, Brasília. Anais do XIII Seminário de História da Cidade e do Urbanismo. Brasília: Universidade de Brasília, 2014. Disponível em: $<$ http://www.shcu2014.com.br/content/discursos-do-urbanismo-em-goiania-dainstrumentalizacao-politica-ao-surgimento-campo>. Acesso em: 5 fev. 2018.

MENDES, M. O curso de Arquitetura da Escola de Engenharia Mackenzie. In: ALVIM, ATB.; ABASCAL, E.H.S.; ABRUNHOSA, E.C. (Orgs.). Arquitetura Mackenzie 100 anos FAU-Mackenzie 70 anos: pionerismo e atualidade. São Paulo: Editora Mackenzie, 2017. p. 36-74.

MENDONÇA, Jales Guedes Coelho. A invenção de Goiânia: o outro lado da mudança. Goiânia: Editoria Vieira, 2013.

MENESES, Ulpiano T. Bezerra de. Morfologia das cidades brasileiras: introdução ao estudo histórico da iconografia urbana. Revista USP, São Paulo, v. 30, p. 144-155, jun./ago. 1996.

MONBEIG, Pierre. Goiânia. In: INSTITUTO BRASILEIRO DE GEOGRAFIA E ESTATÍSTICA (Ed.). Goiânia. Rio de Janeiro: Serviço Gráfico do Instituto Brasileiro de Geografia e Estatística, 1942. p. 76-81.

MONEGATTO, Karina Raimo Benassi. Do artífice ao peão: a constituição e a quebra do reconhecimento do trabalhador da construção civil - referencial teórico e histórico. In: LOPES, João Marcos; LIRA, José (Orgs.). Memória, Trabalho e Arquitetura. São Paulo: Editora da Universidade de São Paulo, 2013. 
MONTEIRO, Ofélia Sócrates do Nascimento. Como nasceu Goiânia. São Paulo: Empresa gráfica da Revista dos Tribunais, 1938.

MONTEIRO, Rosana Horio. A fotografia em Goiânia nas primeiras décadas do séxulo XX. Revista UFG, Goiânia, ano X, n. 5, p. 88-107, 2008.

MOOS, Stanislaus von (Ed.); SCHEIDEGGER, Ernst. Chandigarh 1956. Zurique: Scheidegger \& Spiess, 2010.

MORSE, Richard M. As cidades "periféricas" como arenas culturais: Rússia, Áustria, América Latina. Estudos Históricos, Rio de Janeiro, v. 8, n. 16, p. 205-225, 1995.

MUSEU DA IMAGEM E DO SOM DE GOIÁS. O Fotógrafo Sílvio Berto. Goiânia: Agência Goiana de Cultura Pedro Ludovico Teixeira, 2001.

. Pioneiros da fotografia em Goiânia. Goiânia: Agência Goiana de Cultura Pedro Ludovico Teixeira, 2002.

NEPOMUCENO, Maria de Araújo. A Revista "Oeste": seus intelectuais e a organização da cultura e modernidade em Goiás (1942-1944). In: Congresso Brasileiro de História da Educação, 5., 2008, Aracaju. Anais do V Congresso Brasileiro de História da Educação. Aracaju: Universidade Federal de Sergipe, 2008, p. 1-11.

NETTO, Pimenta. Anais do Batismo Cultural de Goiânia - 1942. Goiânia: Gráfica O Popular, 1969.

NUNES, Jordão Horta. O pioneiro Sílvio Berto: fotografia e sociabilidade. Sociedade e Cultura, Goiânia, v. 4, n. 1, p. 107-143, jan./jul. 2001.

OLIVEIRA, Eliézer Cardoso de. Imagens e mudança cultural em Goiânia. 1999. 234 f. Dissertação (Mestrado em História) - Instituto de Ciências Humanas e Filosofia, Universidade Federal de Goiás, Goiânia, 1999.

OLIVEIRA, Francisco de. O Estado e o urbano no Brasil. In: BARROS, Joana; SILVA, Evanildo Barbosa da; DUARTE, Lívia (Orgs.). Caderno de debates 2. Cidades e conflito: o urbano na produção do Brasil contemporâneo. Francisco de Oliveira e Cibele Saliba Rizek. Rio de Janeiro: FASE, 2013.

OLIVEIRA, Guilherme Talarico de. A "modernidade múltipla" brasileira na trajetória do fotógrafo Alois Feichtenberger. Revista Photo \& Documento, Brasília, n. 5, ago. 2018.

PALACÍN, Luis; MORAES, Maria Augusta de Sant'Anna. História de Goiás (1722-1972). Goiânia: Editora da UCG; Editora Vieira, 2008.

PANERAI, Philippe. Análise urbana. Brasília: Editora Universidade de Brasília, 2006.

PATETTA, Luciano. A questão do moderno. Tradução: Maria Helena da Fonseca Hermes e Aline Coelho Sanches. Risco: Revista de Pesquisa em Arquitetura e Urbanismo (Online), São Carlos, n. 15, p. 99-104, jan. 2012.

PERES, Selma Martines. A Informação Goyana e Oeste e as estratégias para uma nova civilidade em Goiás (1917-1944). In: Simpósio Internacional de Processos Civilizadores: Civilidade, Fronteira e Diversidade, 14., 2012, Dourados. Anais do XVI Simpósio Internacional de Processos Civilizadores. Dourados: Universidade Federal da Grande Dourados, 2012, p. 1-11.

POHL, João Emanuel. Viagem no interior do Brasil - empreendida nos anos de 1817 e 1821. Rio de Janeiro: Instituto Nacional do Livro, 1951.

PRADO JR., Caio. Formação do Brasil contemporâneo: colônia. São Paulo: Companhia das Letras, 2011. 
QUEIROZ, Cláudio José Pinheiro Villar de. Chandigarh, Brasília e suas abstrações construídas. In: MUSEU NACIONAL. Brasília - Chandigarh: patrimônio moderno. Fotografias de Stéphane Herbert. Brasília, 2010. p. 46-51.

RAMA, Angel. La ciudad letrada. Montevidéu: Arca, 1998.

RAMOS, H. Carvalho. Tropas e Boiadas. São Paulo: Monteiro Lobato e Cia Editores, 1922.

REIS FILHO, Nestor Goulart. A urbanização e o urbanismo na região das minas. São Paulo: FAU/USP, 1999. (Série Urbanização e Urbanismo. Cadernos de Pesquisa do LAP, 30).

RIBEIRO, Luiz Cesar de Queiroz. Transferências, empréstimos e traduções na formação do urbanismo no Brasil. In: ; PECHMAN, Robert (Orgs.). Cidade, povo e nação: gênese do urbanismo moderno. Rio de Janeiro: Letra Capital; Observatório das Metrópoles, 2015. p. $15-21$.

RIBEIRO, Maria Eliana Jubé. Goiânia: os planos, a cidade e o sistema de áreas verdes. Goiânia: Editora da UCG, 2004.

RICOEUR, Paul. A memória, a história, o esquecimento. Campinas: Editora da Unicamp, 2007.

ROMERO, José Luis. Latinoamérica: las ciudades y las ideas. Buenos Aires: Siglo Veintuno Editores, 2005.

SABINO JÚNIOR, Oscar. Goiânia documentada. São Paulo: Edigraf, 1960.

SAINT-HILAIRE, Auguste de. Viagem à província de Goiás. Belo Horizonte: Editora Itatiaia; Editora da Universidade de São Paulo, 1975.

SANDES, Noé Freire. Memória e história de Goiás. In: SANDES, Noé Freire et al. (Orgs.). Memória e região. Brasília: Ministério da Integração Nacional; Universidade Federal de Goiás, 2002. p. 17-32.

; ARRAIS, Cristiano Alencar. A historiografia goiana entre dois tempos: Goiás e Goiânia. OPSIS, Catalão, v. 12, n. 1, p. 397-412, 2014.

SAVAGE-LANDOR, A. Henry. Across unknown South America. Boston: Little, Brown and Company, 1913.

SILVA, Karinne Machado. Álbuns da cidade de Goiânia: visualidade documental (19331940). Goiânia: Editora da PUC Goiás; Kelps, 2012.

SILVA, Luciano Oliveira. Utopia e realismo: a construção narrativa sobre Goiânia na década de 1940. 2014. 178 f. Dissertação (Mestrado em História) - Faculdade de História, Universidade Federal de Goiás, Goiânia, 2014.

SILVA, Luiz Sérgio Duarte da. História dos bairros de Goiânia. In: (Org.). Relações cidade-campo: fronteiras. Goiânia: Editora UFG, 2000. p. 129-153.

SOUZA, Candice Vidal e. Fronteira no pensamento social brasileiro: o sertão nacionalizado. Sociedade e Cultura, Goiânia, v.1, n. 1, p. 55-61, jan./jun. 1998.

STEIN, Clarence. Toward new towns for America. Chicago: The University Press of Liverpool, 1951.

SCHWARCZ, Lilia Moritz; STARLING, Heloisa Murgel. Brasil: uma biografia. São Paulo: Companhia das Letras, 2015.

TEIXEIRA, Pedro Ludovico. Memórias. Goiânia: Editora Cultura Goiana, 1973.

TELES, José Mendonça. Memórias goianienses. Goiânia: Editora da PUC Goiás, 2012. 
TITO, Keith Valéria. Memória de identidade de um bairro: Campinas sob as lentes de Hélio de Oliveira. 2008. 224 f. Dissertação (Mestrado em História) - Faculdade de Ciências Humanas e Filosofia, Universidade Federal de Goiás, Goiânia, 2008.

TOPALOV, Christian. Os saberes sobre a cidade: tempos de crise? Espaço e Debates, São Paulo, n. 34, p. 28-38, 1991.

VARGAS, Nilton. Racionalidade e não-racionalização: o caso da construção habitacional. In: ; FLEURY, Afonso Carlos Corrêa (Orgs.). Organização do trabalho: uma abordagem interdisciplinar. Sete casos brasileiros para estudo. São Paulo: Atlas, 1998. p. 195-219.

VIOLICH, Francis. Cities of Latin America: housing and planning to the south. Nova Iorque: Reinhold Publishing Corporation, 1944.

WARCHAVCHIK, Gregori. São Paulo e a arquitetura nova. In: ; MARTINS, Carlos Alberto Ferreira (Org.). Arquitetura do século XX e outros escritos. São Paulo: Cosac Naify, 2006. p. 161-163.

WIEDERHECKER, Clyce Louise; CHAVES, Elza Guedes; PEREIRA, Luís Araújo. Memória social de trabalhadores da construção de Goiânia. Goiânia: CECUP/UFG, 1987. cad. 2, v. 1.

WILHEIM, Jorge. Brasília 1960: uma interpretação. Acrópole, São Paulo, ano 22, n. 256, p. 18-49, fev. 1960.

WILLIAMS, Raymond. $O$ campo e a cidade: na história e na literatura. São Paulo: Companhia das Letras, 1989.

ZICMAN, Renée Barata. História através da imprensa: algumas considerações metodológicas. Projeto História, São Paulo, v. 4, p. 89-102, 1985.

\section{Fontes}

\section{Acervos iconográficos e hemerotecas}

Acervo do Arquivo Histórico Estadual de Goiás

Acervo do Centro de Pesquisa e Documentação de História Contemporânea do Brasil da Fundação Getúlio Vargas

Acervo da Hemeroteca Digital da Biblioteca Nacional

Acervo do Instituto Moreira Salles

Acervo da Library of Congress

Acervo do Museu da Imagem e do Som de Goiás

Acervo da Folha de S. Paulo

Acervo de O Estado de S. Paulo

Acervo de O Globo

Acervo da Secretaria Municipal de Planejamento Urbano e Habitação de Goiânia

\section{Álbuns fotográficos}

BARBOSA, Orlando. Álbum de Goiaz. c. 1939. 276 f.

BERBERIAN, Haroutium. Goiânia: uma cidade por decreto. Década de 1940. 12 fotografias, $\mathrm{p} \& \mathrm{~b}$.

BERTO, Sílvio. Lembranças de Goiânia: "a capital caçula". Década de 1940. 10 fotografias, $\mathrm{p} \& \mathrm{~b}$. 
FEICHTENBERGER, Alois. Expedições ao norte. 1937. 106 fotografias, p\&b.

NETO, Oscar Cunha. Álbum de Fotografias sobre o Planejamento e Construção da Cidade de Goiânia. Edição comemorativa ao 600 aniversário de criação do município. $1995.78 \mathrm{f}$.

SÃO Paulo antigo, São Paulo moderno: álbum comparativo. São Paulo: Edições Melhoramentos, 1953.

\section{Entrevistas}

BIANCHI, Benito M. Benito M. Bianchi: depoimento [dez. 2000]. Entrevistadora: Stela Horta Figueiredo. Goiânia: Museu da Imagem e do Som de Goiás, 2000. Entrevista concedida ao projeto Pioneiros da Fotografia em Goiânia do Museu da Imagem e do Som de Goiás.

OLIVEIRA, Eleyson Rocha de. Eleyson Rocha de Oliveira: depoimento [jan. 2001]. Entrevistadora: Stela Horta Figueiredo. Goiânia: Museu da Imagem e do Som de Goiás, 2001. Entrevista concedida ao projeto Pioneiros da Fotografia em Goiânia do Museu da Imagem e do Som de Goiás.

TEIXEIRA, Dalmo. Dalmo Teixeira: depoimento [fev. 2002]. Entrevistadora: Stela Horta Figueiredo. Goiânia: Museu da Imagem e do Som de Goiás, 2002. Entrevista concedida ao projeto Pioneiros da Fotografia em Goiânia do Museu da Imagem e do Som de Goiás.

\section{Periódicos}

5 DE julho - uma data revolucionária. Revista Oeste, Goiânia, ano III, n. 18, p. 6, jul. 1944. $9^{\circ}$ ANIVERSÁRIO de Goiânia. O Popular, Goiânia, p. 1, 25 out. 1942.

A TELHA abençoada sob que Goiânia vive. Folha de Goiaz, Goiânia, p. 1, 25 mar. 1943.

A PROPAGANDA e o progresso de Goiaz. Revista Oeste, Goiânia, ano III, n. 21, p. 17-18, out. 1944.

BROCA, José Brito. Visão de Goiânia. Revista Oeste, Goiânia, ano III, n. 18, p. 32-35, jul. 1944.

BROWN, Celso P. Arborização de Goiânia. Folha de Goiaz, Goiânia, 29 out. 1939.

CASTRO, Alfredo de. Brasil desconhecido. Revista Oeste, Goiânia, ano II, n. 4, p. 5-6, mai. 1943.

COMO se deve definir o verdadeiro urbanismo. A Manhã, Rio de Janeiro, p. 3-8, 29 out. 1941.

CONSTRUÇÃO de Brasília inspirou músicas contra e a favor da nova capital. Correio Braziliense, Brasília, abr. $2013 . \quad$ Disponível em: $<$ https://www.correiobraziliense.com.br/app/noticia/cantabrasilia/2013/04/21/internacantabrasilia,361444/construcao-de-brasilia-inspirou-musicascontra-e-a-favor-da-nova-capital.shtml>. Acesso em: 8 mar. 2019.

CONSTRUÇÕES em Goiânia. Folha de Goiaz, Goiânia, 15 nov. 1947.

EM Goiânia o urbanista professor Agache. O Popular, Goiânia, 8 ago. 1940.

EXPERIÊNCIA brasileira apoia projeto da capital portenha. Diário Oficial do Distrito Federal, ano XVI, n. 212, p. 1, 8 nov. 1989.

FIGUEIREDO, José de Lima. Goiânia - uma passada do progresso. Revista Oeste, Goiânia, ano III, n. 18, p. 22-24, jul. 1944. Goiânia, a joia do planalto. Revista da Semana, Goiânia, p. 3, ago. 1942. 
FIGUEIREDO, Paulo Augusto de. O Brasil comeu espinafre. Revista Oeste, Goiânia, ano I, n. 1, p. 5, jul. 1942 .

. Variações em torno de Goiânia. Revista Oeste, Goiânia, ano II, n. 6, p. 2-4, jul. 1943.

FLEURY, Rosarita. Poema a Goiânia. Revista Oeste, Goiânia, ano III, n. 20, p. 32-33, set. 1944.

FOLHA DE S. PAULO. São Paulo, 2 fev. 1941.

GOES, Álvaro de Campos. A Esmeralda do Oeste. Revista Oeste, ano III, n. 13, p. 13-14, fev. 1944.

GOIÂNIA. Correio da Manhã, Rio de Janeiro, p. 1, 27 mar. 1938.

GOIÂNIA - a cidade que apareceu no sertão. A Noite, Rio de Janeiro, p. 1-3, 4 jul. 1942.

GOIÂNIA cresce e se expande. Folha de Goiaz, Goiânia, 27 ago. 1944.

GOIÂNIA desenvolve-se dia a dia. Goiânia, Goiânia, p. 1, 11 jul. 1936.

GOIÂNIA na opinião do técnico da IBGE. O Popular, Goiânia, 19 jan. 1939.

GOIÂNIA não terá favelas. Folha de Goiaz, Goiânia, p. 3, 22 mai. 1948.

GOIÂNIA - nova capital de Goiaz. O Estado de S. Paulo, São Paulo, p. 1, 20 out. 1935.

GOIÂNIA, oficina de trabalho no oeste brasileiro. Folha de Goiaz, Goiânia, 13 jul. 1944.

GOIÂNIA se iluminou na noite de 23. Folha de Goiaz, Goiânia, 26 out. 1939.

GOIÂNIA - uma obra. Folha de Goiaz, Goiânia, 23 out. 1949.

GOIÁS, através da palavra do seu governador. A Nação, Rio de Janeiro, p. 3-5, 20 out. 1935.

GOYANIA terá forno crematório em vez de cemitério. Correio da Manhã, Rio de Janeiro, p. 3, 17 jan. 1936.

HISTÓRIA da mudança da capital de Goiaz. A Manhã, Rio de Janeiro, p. 3-10, 4 jul. 1942.

INAUGURAÇÃO do Grande Hotel de Goiânia. Correio Official, Goiânia, ano LXXXI, n. 3373, p. 1, 27 jan. 1937.

LIMA, Attilio Corrêa. Goiânia - a nova capital de Goiás. Arquitetura e Urbanismo, Rio de Janeiro, ano II, p. 32-34, jan./fev. 1937.

MAIS energia elétrica para Goiânia! Folha de Goiaz, Goiânia, p. 1, 25 dez. 1949.

O OESTE começa onde termina o asfalto. A Manhã, Rio de Janeiro, p. 9, 26 set. 1941.

MORBACH, A. Bastos. Goiânia. Revista Oeste, Goiânia, ano III, n. 15, p. 24, abr. 1944.

O CASO de Goiânia. A Manhã, Rio de Janeiro, p. 8, 29 ago. 1941.

O DIA de Goiânia. Revista Oeste, Goiânia, ano III, n. 18, p. 1, jul. 1944.

O GOVERNO de Goyaz à imprensa. O Globo, Rio de Janeiro, 14 jun. 1938.

O HUMORISMO goiano e o caso da luz desta Capital. Folha de Goiaz, Goiânia, p. 4, 30 dez. 1943.

O MAIOR edifício de Goiânia. Folha de Goiaz, Goiânia, 20 nov. 1946.

O OPERARIADO desta Capital está de parabéns. Folha de Goiaz, Goiânia, p. 1, 3 nov. 1935.

O VALOR histórico da cidade de Goiaz. Folha de Goiaz, Goiânia, 10 dez. 1944.

PIACESI, Inês et al. Goiânia na opinião nacional. Revista Oeste, Goiânia, ano II, n. 6, p. 4-6, jul. 1943.

"PORQUE mudei a capital do Estado para a cidade Goiânia". A Manhã, Rio de Janeiro, p. 37, 5 jul. 1942. 
PRAZERES, Otto. Goiânia. Folha de Goiaz, Goiânia, 8 jun. 1941.

RAMOS, Vitor de Carvalho. Agradecimento de Vitor de Carvalho Ramos. Revista Oeste, ano III, n. 13, p. 29, fev. 1944.

SANTANA, M. Leite de. Goiânia, um município padrão. Revista Oeste, ano III, n. 20, p. 39, set. 1944.

SENSACIONAL entrevista que o Dr. Benjamin Vieira, ilustre secretário geral do Estado, concedeu a "Goiânia". Goiânia, Goiânia, ano I, n. 30, p. 1, 11 jun. 1936.

UM URBANISTA brasileiro na Embaixada da Bolívia. O Globo, Rio de Janeiro, 8 out. 1943. VILA Nova e seu drama doloroso. O Popular, Goiânia, p. 1, 1 jul. 1945. 
Todos os esforços foram empreendidos para a identificação e atribuição de créditos às fotografias, embora muitas não constassem autoria. Em caso de eventual omissão, os direitos encontram-se reservados aos seus titulares. 


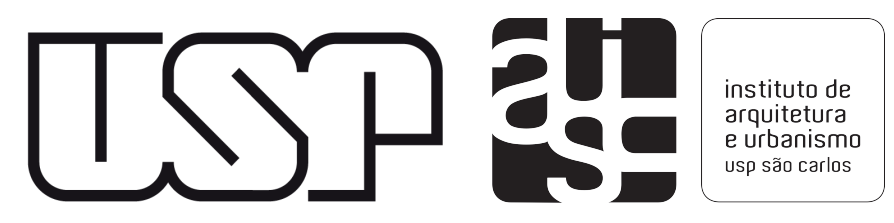

